\title{
Articles
}

\section{The Jury's Rise as Lie Detector}

\author{
George Fisher ${ }^{\dagger}$
}

\section{CONTENTS}

I. The Ordeal and the Jury Trial: Theoretical Prelude . . . . 585

A. Seeking Divine Sanction for Criminal Verdicts . . . . . . . . 587

B. The Special Case of Capital Convictions . . . . . . . . . . 595

C. The Reality Beneath the Illusion . . . . . . . . . . . 600

II. The Rise of Defense Witnesses . . . . . . . . . . . . . . 602

A. Curtains Open: The Sixteenth Century . . . . . . . . . . 602

B. The Act To Abolish Hostilities with Scotland . . . . . . . . . 609

C. The Treason Trials and the Treason Act of 1696 . . . . . . 615

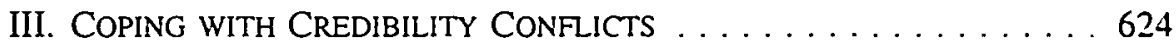

A. Witness Competency Rules and the Rule of Bethel's Case . . . 624

B. Empirical Interlude: Criminal Trials in an

Eighteenth-Century Court . . . . . . . . . . . 638

C. Alibis and the Problem of Unavoidable Conflicts . . . . . . 650

IV. THE Rise of DefENDANT Testimony $\ldots \ldots \ldots \ldots \ldots \ldots 656$

A. The Downfall of Witness Competency Rules in Civil Cases . . 659

B. The Downfall of the Prohibition Against Defendant Testimony in

Criminal Cases .......................662

$\doteqdot$ Associate Professor, Stanford Law School. I would like to thank Al Alschuler. Barbara Babcock. Simon Devereaux, Eric Foner, Barbara Fried, Lawrence Fnodman. Tom Gallanis, David Gold, Hank Greeley, Tom Green, Tom Grey, Dick Helmholz, Adam Hirsch. Dan Klerman. John Langbein. Mitchael Macnair, Barbara Shapiro, Avi Soifer, Bob Weisberg. and Kenjı Yoshıno for guiding my research and commenting critically and perceptively on earlier drafts. Alexıs Haller. Allison Marston. Tamı Swiger. Michael Risher, Mark Houle, and Lisa Tingue contrbuted long hours of excellent researth suppon $X_{t, ~}$ Chen and Andrew Gurthet of the Stanford Law School Library collected dozens of far-flung sourtes And Ariela Dubler and her editorial colleagues have worked with care and insight 
C. The Link to African Americans' Right To Testify: Civil Parties . ...................... 671

D. The Link to African Americans' Right To Testify:

Criminal Defendants . . . . . . . . . . . . . . . . . . . 674

1. The Campaign of $1862 \ldots \ldots \ldots \ldots \ldots \ldots \ldots 676 \ldots \ldots \ldots$

2. The Campaign of $1864 \ldots \ldots \ldots \ldots \ldots \ldots 678$

3. The Campaign of $1866 \ldots \ldots \ldots \ldots \ldots \ldots \ldots 6 . \ldots \ldots$

a. Massachusetts .................683

b. Other States . . . . . . . . . . . . . . . . . . 691

E. The Link to African Americans' Right To Testify:

Assessing the Evidence . . . . . . . . . . . . . . 696

V. The Allure of THE Black BoX $\ldots \ldots \ldots \ldots \ldots \ldots \ldots 97$

APPENDIX A: STATUTES AND CONSTITUTIONAL PROVISIONS PERMITTING

TESTIMONY By Civil PARTIES . . . . . . . . . . . . . 709

APPENDix B: STATUTES AND CONSTITUTIONAL PROVISIONS ABolishing

RULES AGAINST TESTIMONY BY NONWHITES $\ldots \ldots \ldots \ldots \ldots 712$ 
We say that lie detecting is what our juries do best. In the liturgy of the trial, we name the jurors our sole judges of credibility and call on them to declare each witness truthteller or liar.' All hierarchies of rank, learning, and technical prowess give way in the face of this asserted power of common jurors to spot a lie: In most jurisdictions today, no trial judge may advise the jury that a witness has lied. ${ }^{2}$ No psychiatric expert may comment on a witness's credibility. ${ }^{3}$ Rarely may a polygraph technician lecture to jurors about a witness's pulse and pressure, tension or temperature: The job of lie

1. See, e.g., FifTH CiRCuIr Criminal JuRY INSTRuCtIONS $\$ 1.09$ (1990) ("You are the sole judges of the credibility or 'believability' of each witness and the weight to be given the wilness's (estumony."): CALIFORNIA JURY INSTRUCTIONS, CRIMINAL $\S 2.20$ (Wesi 1993) ("You are the sole judges of the believability of a witness . . ."); 17 LOUISIANA CIVIL LAW TREATISE: CRIMINAL JURY INSTRLCTIONS $\$$ 3.04 (Cheney C. Joseph, Jr. \& P. Raymond Lamonica eds.. 1994) ("IYou are] the sole judges of the credibility of witnesses . . . ."); WISCONSIN JURY INSTRUCTIONS. CRIMINAL $\$ 300$ (1962 \& Supp. 1976) ("You are the sole judges of the credibility of the several witnesses . . . .): United States v Bamard, 490 F.2d 907, 912 (9th Cir. 1973) ("[T]he jury is the lie detector in the courroom.").

2. Even in our federal system, which still permits judges to commenl on the evidence, a judge who dares comment on credibility risks likely reversal. See. e.g.. Quercia v. United States, 289 U.S. 466.471 (1933) (reversing a conviction after the judge said that wiping one's hands, as the defendant had done on the stand, was a common sign of lying, because "[i]t was for the jury to test the credibiltty of the defendant as a witness"). The great majority of American states long ago barred judges from commenung to junes on the weight of the evidence or the credibility of the witnesses. In a small number of states, however. judges still may do so. See infra note 597.

In England, where judges generally retain the power to comment on the evidence, it is nonetheless clear that they "should never give an express indication of [their] own disbelief in relation to the evidence of a witness, especially the evidence of an accused. even in a case in which the evidence wamants incredulity." ADRIAN KEANE. THE MODERN LAw OF EvidENCE 31 (3d ed. 1994) (citing a 1988 case in which the court criticized a judge for telling the jury he thought the defendant was lying): see ROSEMARY Pattenden, Judicial Discretion and Criminal Lmgation 180.81 (1990). But nol that long ago. a commentator could say that "[s]uch remarks as-'I should not be surpnsed, gentlemen of the jury, if you will attach but very little weight to the testimony of Mr." are nol uncommon." PEvoleton HOWARD. CRIMINAL JUSTICE IN ENGLAND 377 (1931).

3. An expert's opinion about another witness's credibility ordinanly does not assist the jury. the cases say, and so falls short of the threshold for admissibility of expert evidence. See FED. R. EvID. 702: see also, e.g., Bachman v. Leapley, 953 F.2d 440, 441 (8th Cir. 1992) ("It is the exclusive province of the jury to determine the believability of the witness. . . An expen is not permitted to offer an opinion as to the believability or truthfulness of a victim's story."): United States v. Benson, 941 F.2d 598, 60-4 (7th Cir. 1991) ("Credibility is not a proper subject for expert testimony: the jury does not need an expen to tell it whom to believe .....), modified, 957 F.2d 301 (7th Cir. 1992): State v. Boston. 545 N.E.2d 1220. 1240 (Ohio 1989) (holding that an expert may not give an opinion about the veracily of a child wilness). Some courts and commentators, however, reject such categorical holdings and say that expert testimony at tumes may help the jury assess credibility, especially when the witness is young or mentally impaired. See. e.g. United States v. Shay, 57 F.3d 126, 131 -34 (Ist Cir. 1995): Margarel A. Berger. United States v. Scop: The Common-Law Approach to an Expert's Opinion Aboul a Winess's Credibilin Stull Does Not Work. 55 BROOK. L. REV. 559 passim (1989).

4. The very case that stands for the system's suspicion of scientufic evidence. Foie v: Untied States. 293 F. 1013 (D.C. Cir. 1923), rejected lie-detecting machinery. In the few years since the Supreme Court held that the Federal Rules of Evidence displaced the Frye test, see Daubert v. Merrell Dow Pharm.. Inc., 509 U.S. 579, 589 (1993), two federal appeals cours have retracted per se bars aganst polygraph evidence. See United States v. Cordoba, 104 F.3d 225, 228 (9th Cir. 1997); United States v. Posado. 57 F.3d 428, 434 (5th Cir. 1995); see also United States v. Piccionna. 885 F.2d 1529. 1535 (1lith Cir. 1989) (rejecung the per se bar pre-Daubert). A third appeals court has restaled its general ban. See United States v. Sherlin. 67 F.3d 1208, 1216 (6th Cir. 1995) ("As a general rule, the results of a polygraph are inadmissible."); see also United States v. Kwong, 69 F.3d 663,668 (2d Cir. 1995) (stating that "[c]ven assuming that polygraph results are admissible under Rule 702 (and we are unlikely to so hold bocause the specific testumony here would not likely 'assist the trier of fact")"). I have found only three federal district coun cases in which 
detecting belongs to the jurors alone. Nor may we later, once the jurors have done their job of sifting truth from falsehood, review how they did it. In a trial process in which we hide so much of the law and evidence from the jurors, this they hide entirely from us.

We do not leave our jurors wholly unequipped for this task of lie detecting. They come to court, as we so often tell them, with their common sense and may reject any evidence that defies it. Inside court, we give them three more lie-detecting tools: the oath, demeanor evidence, and crossexamination. Every witness must promise to tell the truth, face the jurors for their scrutiny, and endure the challenge of opposing counsel. If these tools are lacking, we do not put the jury to the task of detecting lies. Hence we usually do not ask jurors to judge the truthfulness of an out-of-court witness. But this general bar against hearsay is our only broad exception to the otherwise unqualified rule that leaves questions of credibility to the jury.

Of course, many cases impose no particular burden on the jury's powers to ferret out lies. In many cases there is no conflict in testimony. In many others there is a conflict, but the jury is able to attribute it to mistake or misperception or memory loss. In many cases, however, two witnesses tell two stories that cannot innocently be reconciled. Here the jurors must call someone a liar-indeed they must call someone a perjurer. Still, at least in civil cases, in which the jurors must merely say which witness was more truthful, their task remains relatively simple. Criminal cases mount a starker challenge. If the defendant has taken the stand to refute the testimony of a prosecution witness, then the jury may not convict unless it is prepared to credit the accuser's testimony over the defendant's and to do so beyond a reasonable doubt. To be sure, it is not wildly uncommon for defendants to proclaim their innocence in the face of a freight train of evidence-and when they do, jurors may readily brand them perjurers as well as thieves. But there are many criminal cases in which we give the jurors no substantial evidence other than the oath of the accuser and the oath of the accused. In such cases, we put jurors to the intractable task of searching the faces and gestures of strangers for the signs of deceit.

Our unguarded confidence that jurors are up to this task is the more remarkable for being so probably wrong. There is little evidence that regular people do much better than chance at separating truth from lies. We tend to rely on worthless clues and to misread others. ${ }^{5}$ But although the jury does not

polygraph evidence was admitted. See United States v. Galbreth, 908 F. Supp. 877, 896 (D.N.M. 1995); Ulmer v. State Farm Fire \& Cas. Co., 897 F. Supp. 299, 304 (W.D. La. 1995); United States v. Crumby, 895 F. Supp. 1354, 1364-65 (D. Ariz. 1995).

On November 3,1997, the Supreme Court heard argument on the constitutionality of a per se ban against the use of polygraph evidence by criminal defendants in military court. See United States v. Scheffer, 44 M.J. 442 (C.M.A. 1996), cert. granted, 117 S. Ct. 1817 (1997).

5. See infra notes $606-607$ and accompanying text. 
guarantee accurate lie detecting, it does detect lies in a way that appears accurate, or at least in a way that hides the source of any inaccuracy from the public's gaze. By permitting the jury to resolve credibility conflicts in the black box of the jury room, the criminal justice system can present to the public an "answer"-a single verdict of guilty or not guilty-that resolves all questions of credibility in a way that is largely immune from challenge or review. By making the jury its lie detector, the system protects its own legitimacy.

This error-erasing function of jury lie detecting disables other mechanisms that are supposed to guard against wrongful verdicts. It relieves both judge and prosecutor of their usual charge to evaluate the evidence before passing the case to the jury. At the motion for directed verdict, which is usually a chance for the trial judge to rid the system of a fimsy prosecution, the judge simply assumes the truthfulness of the government's witnesses and leaves the problem of lie detecting altogether to the jury. ${ }^{6}$ Appellate courts refuse to revisit the jury's judgments of credibility. And prosecutors, who normally must assure themselves that they have probable cause to bring charges, are able to avoid any meaningful duty to screen out weak cases when guilt turns on a question of credibility. The sworn testimony of a named witness who is not obviously delusional is all the prosecutor needs to satisfy probable cause.'

In the pages ahead I want to search out the source of this quiet confidence that the jury can answer all credibility questions. When and why did the system declare that jurors had the wisdom to arbitrate unvarnished credibility conflicts at criminal trials? To the question "when," the surprising answer is very recently. If we walk back a mere 140 years through the nearly 800 -year history of the criminal trial jury, we find ourselves at a time when no jury had to choose between the sworn testimony of accuser and accused at a criminal trial. Not until the second half of the nineteenth century could accused criminals anywhere in the common law world testify under oath at their own trials. Defendants could tell their stories, but they could not swear to them, and a jury torn between two conflicting stories could choose simply to credit sworn accusation over unsworn denial.

If we walk back another 160 years, we arrive at a time when no jury had to choose between the sworn testimony of prosecution and defense witnesses at a serious criminal trial. Not until the turn of the eighteenth century could accused felons call sworn witnesses. They could call unsworn witnesses, but

6. See 26 JAMES WM. MOORE ET AL., MOORE'S FEDERAL PRACTICE $\$ 629.06$, al 628-29 (3d ed. 1997) ("The rule is well settled, of course, that on a motion for acquitial, all doubis as to credibility must be resolved in favor of the govemment.").

7. Many prosecutors, however, impose on themselves a higher charging standard. See. e.g., Carol A. Corrigan, On Prosecutorial Erhics, 13 Hastings CONST. L.Q. 537. $539-40$ (1986) (cilıng Calıfomia prosecutors' charging standards, which provide that proseculors should be "satusfied" of the defendant's guilt before bringing charges). 
a jury in doubt could simply prefer the sworn evidence. Walking back 150 more years, to the middle of the sixteenth century and before, we come to a time when only the prosecution could present any sort of witness at a criminal trial. Although defendants could speak, they were not sworn, and they could call no witness to speak for them. The juries that presided over the rump trials of these early years faced nothing like our modern conflicts of oaths.

This thumbnail history suggests that the "why" question is somewhat more complicated than we might have anticipated. Before we can inquire why the system gave the jury the unbounded discretion to resolve credibility conflicts between sworn witnesses, we must first examine why the system in its early days sought to avoid such credibility conflicts altogether. The answer to both questions, I will argue, turns on the system's need for legitimacy-for public confidence in the accuracy of its outcomes. ${ }^{8}$ In the early years of the criminal trial jury, the system sought to stake its claim to legitimacy primarily in the oath and in the perceived divine power of the oath to compel truthful testimony. The oath's central role demanded that the system avoid sworn credibility conflicts, because any such conflict would reveal in a visible and obvious way the oath's inadequacy to assure truthful testimony. Hence when the system first permitted conflicts in testimony to emerge, it did not permit sworn conflicts.

This and other contrivances to avoid conflicts in oaths permitted the system to embrace an evidentiary presumption that all sworn evidence was truthful-a presumption that sounds distinctly alien to us, yet persisted in stronger or weaker form throughout much of the jury's history. In time, however, for reasons I will discuss later, the system gradually had to release its grip on the oath as a source of legitimacy. As it did, it turned to the jury as an alternative. During the last several centuries of the jury's history, the system has committed ever more-and more intractable-credibility conflicts

8. When I speak of the system's need for legitimacy, I mean only this: Systemic actors believed it was in their interest to make the system's judgments acceptable to the public and therefore packaged those judgments in a way they believed the public would accept. I would add-though it is not essential to my argument-that the authorities' instincts about what the public would accept were probably sound and probably responded to public expressions of confidence or discontent. I am, however, making no claim about the legitimating power of law-its power to shape what the public wants-of the sort Alan Hyde finds so unsustainable. See Alan Hyde, The Concept of Legitimation in the Sociology of Law, 1983 WIS. L. REV. 379, $385 \mathrm{n} .5$ ("It is this last model [of legitimation], the process that leads from law to belief in legitimacy to particular political behavior, that I criticize in this article."). Much less am I offering a judgment about "the substantive standard that the law is intended to project," of the sort Charles Nesson seems to embrace when he argues that " $[t]$ he aim of the factfinding process is . . . to generate acceptable [verdicts]." Charles O. Nesson, The Evidence or the Event? On Judicial Proof and the Acceptability of Verdicts, 98 HARV. L. REV. 1357, 1359, 1362 (1985).

I use the concept of legitimacy to suggest simply that a "regime that announces [popular] norms and appears to be pursuing them is ... somewhat more likely to become popular among the population" and therefore, a regime that hopes for popular support will at times defer and conform to popular ideals of justice. Hyde, supra, at 414 . Hyde allows that this proposition "is probably true but hardly interesting." Id. at 415 . 
to the jury's black box. And the jury, in loyal support of the system's legitimacy, has issued crisp and impregnable verdicts.

This Article tells the long story of the jury's slow coming of age as the system's lie detector at criminal trials. It chronicles the deaths of the old evidence rules that effectively withheld from the jury the task of settling credibility conflicts between sworn witnesses. Like the characters of many good stories, these rules led uneventful lives but suffered noteworthy deaths, touched by the intrigue of treachery and factional strife. I will emphasize two features of the evolutionary process. First, it was astoundingly slow. Despite the jury's attractiveness as a means of resolving credibility conflicts, the system displayed a remarkable resistance to change, an inertia of planetary proportions disturbed only by explosive events. Second, the most important of these explosions were external to the system. As a result, the evolutionary process was not principled, driven by a conviction that the jury can and should resolve credibility conflicts. Instead, the rule changes that most greatly expanded the potential for sworn credibility conflicts at criminal trials were products of political firestorms. In this sense, faith in the jury's powers of lie detection only followed the force of events.

Before I begin, it would be wise to say more clearly what I mean by the task of lie detecting. Although I hope to prove that the jury's formal and complete role as the system's lie detector is relatively new, I do not aim to persuade the reader that the thought processes of modern jurors are new. For as long as witnesses have made claims to juries about past events, jurors have had the power-and perhaps the inclination - to disbelieve those witnesses and to disregard what they said. In fact, the lie-detecting role of juries in past generations may have been much like the lawmaking role of juries today. Today we officially declare that juries play no role in making law. Yet not only do juries manifestly make law-witness the repeated refusals of Michigan

9. I do not mean by emphasizing the role of these external events to embrace a "social" theory of legal evolution-one in which the moving forces are found in the sociely al large and not in legal actors or institutions. See LAWRENCE M. FRIEDMAN, LAW AND SOCIETY $93-99$ (1977) (defining and disungushing "internal" and "social" theories of law). Nor by stressing how the justuce system's need for legutumacy helped to shape legal rules do I mean to embrace an "intemal" theory of change. In fact. I am in no position to evaluate the relative importance of external and internal forces on the changes I study here. I exclude altogether from my study (because of external constraints of ume and space) the role played by two hugely important external developments- the progressive secularization and democratization of Englısh and American societies, which did much both to break down faith in the power of the aath to assure inuth and to build up confidence in the power of juries to detect lies.

In any event, it seems futile to try to maintain this extemal-tnternal distinction. Even if social fores determine "the general drift, the long run trend" of legal evolution, an "'intemal" theory may work reasonably well in explaining minor, shor-run legal events." ld. at 96-97. Conversely, even if law is "largely autonomous and not shaped by societal needs," it is nonetheless influenced by "the lawmakers" being members of the society and sharing its values and experiences." ALAN WATSON. THE EVOLUTION OF LAW 118-19 (1985). In a study covering as much teritory as this one. comprehending both long-run trends and minute doctrinal shifts, both external and intemal forces are bound to play a role. 
juries to convict Jack Kevorkian of assisting suicide ${ }^{10}$-but many observers regard their power to do so as a fundamental part of our trial system. "In a similar way, I will argue that the ideology of the jury trial system at one time required the system to claim that the jury did not act as lie detector, even when the jury's power to make credibility determinations was fundamental to the system's just operation.

Nor do I hope to prove that the task of lie detecting, as a larger, epistemological matter, has changed over time. At least one historian has sought to explain some of the developments I describe here as a function of the evolving way in which people in general-not merely jurors-have resolved conflicts among sources of information. ${ }^{12}$ Although such an evolving epistemology may have played a role in the historical transformation of the jury's lie-detecting function, there are many reasons, which I will review in time, to think it did not. In any event, one can explain the jury's changing role without assuming complex changes in the way most of us think.

Instead, I will argue that the jury's role as lie detector has grown in this somewhat formalized sense: The system has become more and more willing over time to declare that the jury - and not the oath-has the job of screening untrustworthy evidence from the decisionmaking process. We see the system's changing declaration of the jury's role in the gradual erosion of those evidence rules that had spared juries the task of deciding which of two competing witnesses lied under oath. As the system gave the jury ever greater authority to resolve conflicts between sworn witnesses, it thereby declared the jury to be the system's lie detector. It did so, I will argue, because it perceived the jury to be an ever more reliable guarantor of the legitimacy of the system's verdicts-and because it perceived the oath to be an ever less reliable guarantor. Whether juries in practice actually did anything different is largely beside the point, except to the extent that what jurors did might have reflected what the system declared they should do.

In telling the story of the jury's rise as lie detector, I focus on criminal trials for both a principled and an accidental reason. The principled reason is that the task of lie detecting, at least in the modern setting, poses a far greater challenge in criminal than in civil cases. As I noted earlier, although a civil jury may resolve a credibility conflict by a mere preponderance of the evidence, a criminal jury (at least one that chooses to believe the government's

10. See Jack Lessenberry, Jury Acquits Kevorkian in Common-Law Case, N.Y. TIMES, May 15, 1996, at A14; Jack Lessenberry, Kevorkian Again Not Guilty of Aiding Suicide, N.Y. TIMES, Mar. 9, 1996, at A7; David Margolick, Jury Acquits Dr. Kevorkian of Illegally Aiding a Suicide, N.Y. TIMES, May 3, 1994, at A1.

11. See, e.g., Alan Scheflin \& Jon Van Dyke, Jury Nullification: The Contours of a Controversy, LAw \& CONTEMP. PROBS., Autumn 1980, at 51, 85-111; Katherine Bishop, Diverse Group Wants Juries To Follow Natural Law, N.Y. TimEs, Sept. 27, 1991, at B16 (reporting on the Fully Informed Jury Association. a group that lobbies for nullification instructions).

12. See infra notes 118-122 and accompanying text. 
witnesses over the defendant's) must settle the dispute beyond a reasonable doubt. ${ }^{13}$ The accidental reason is that contemporary chroniclers, like legal historians, tended to find criminal cases more interesting-so, for better or worse, we simply know more about them. That is not to say that what we do know about the evolution of civil trials cannot shed light on this study of the criminal jury trial, and in the historical journey that lies ahead, I will from time to time incorporate insights from the civil side.

That journey begins in England in the second decade of the thirteenth century. We start in England because the criminal trial jury emerged there. Later, as the jury moved with the English to America, I will broaden our focus to gather in events from both sides of the Atlantic. We star in the early thirteenth century because the sudden end of trial by ordeal in 1215 gave rise to the first jury trials. When the Church abruptly forbade priests to take part in the ordeal, European justice systems lost a trial mechanism that had served to reveal God's judgment on the guilt of the accused. In Part I, I will explore how the English sought to replace the divine legitimacy of the lost ordeal. I will argue that by staking its verdicts on the oaths of witnesses, the justice system found it could claim that the threat of divine vengeance assured truthful outcomes. Rules that permitted only the prosecution to call witnesses helped, in turn, to protect the legitimacy of the oath by guarding against the embarrassment of conflicting oaths.

As this framework slowly broke down, the system began to tolerate certain kinds of credibility conflicts and to complicate the jury's lie-detecting task. Part II traces the first stages of this dissolution. The appearance of unsworn defense witnesses sometime in the sixteenth century gradually accustomed juries to conflicting stories, if not conflicting oaths. Then, at the very end of the seventeenth century, came a great lurch forward, the first sudden transformation of the jury's lie-detecting role. By two acts of 1696 and 1702 , Parliament gave accused traitors and felons the right to call sworn witnesses. Suddenly, for the first time in the criminal jury trial's 500-year history, juries in serious criminal cases routinely risked having to resolve sworn credibility conflicts. Telling the story of this minor legal revolution will draw us into the vortex of the most violent political and legal storm of the age, which blew about the Stuart treason trials of the 1670s and 1680s and ultimately impelled Parliament to act.

Even after criminal defendants began to call sworn witnesses, the system struggled to maintain the old order and to protect juries as far as possible from having to choose between competing oaths. Part III will examine how it did so. For at least a century and a half following the acts of 1696 and 1702 , several wide-ranging rules of evidence helped to prevent sworn credibility conflicts at trial and to protect the old presumption that all sworn evidence was

13. On the timing of the development of the reasonable doubl standard. see infra note +17 
true. Among these was a broad series of witness competency rules that barred whole categories of witnesses-those thought most likely to lie-from testifying. An evidence rule of narrower application advised juries to reconcile conflicting testimony in a way that would avoid branding any witness a perjurer. Little known today, this rule of Bethel's Case $e^{14}$ amounted in practice to an admonition that juries should call one witness mistaken before calling either witness a liar. These rules worked side by side with others to protect juries from the task of separating truthteller from liar. Taken together, they betrayed the system's continuing anxiety over the jury's emerging role as lie detector.

Part IV recounts the nineteenth-century demise of many of these rules and the resulting rise of the jury as the full-fledged arbiter of credibility disputes. The last and by far most important step in this progress was the end of the rule that barred criminal defendants from testifying under oath. Defendants are, after all, the most prolific witnesses on their own behalf, ${ }^{15}$ and they are for obvious reasons the most likely to lie. Once they won the right to testify under oath, the average jury in the average criminal case could expect to confront a credibility conflict that would require it to declare one of two sworn witnesses a liar. In 1864, the unlikely state of Maine became the world's first common law jurisdiction to take this transformative step, and a host of mainly Northern states followed. The search for the triggering force behind this North-first burst of modernizing activity will lead us into a far greater historical firestorm-the clash between North and South over the legal status of African Americans. The North's decision to grant criminal defendants the right to speak under oath proves to have been, in part at least, one tactic in a very separate battle about the right of freed slaves to testify in Southern courts.

Without such massive external jolts as the Stuart treason trials and the American Civil War, the force of legal inertia might have delayed for decades the jury's progress toward its distinctly modern role as lie detector. Yet there is no question about the direction in which legal evolution was carrying the jury: By some sort of a historical one-way ratchet, the lie-detecting power of the jury has grown consistently and has never, for any sustained period, diminished. In Part V, I will try to explain the forces that dictated the forward direction of the jury's evolution as lie detector. I will suggest that the answer has much to do with the problem of legitimacy and the system's need to

14. The TrYal OF SLINGSBy Bethel, ESQ. 9 (London, R. Harbottle 1681); see infra Section III.A.

15. Based on their 1950s case sample, Harry Kalven and Hans Zeisel reported that the defendant took the stand in $82 \%$ of all cases, but called a friend or family member (the next largest category of defense witness) in only $47 \%$ of cases. See HARRY KALVEN, JR. \& HANS ZEISEL, THE AMERICAN JURY 33 n. 1,137 (1966). Dan Klerman has suggested to me that the doctrine of Griffin v. California, 380 U.S. 609, 615 (1965), which bars prosecutorial comment on the defendant's failure to testify, may encourage more silence by defendants today. 
reduce hard questions to clear answers that the public will accept. For this task, the jury's black box has an undeniable allure.

Now, however, we must begin at the beginning. Part I therefore returns to the jury's earliest years, where we may hope to find the roots of the criminal jury trial's later devotion to the sanctity of a witness's oath.

\section{The Ordeal and the Jury Trial: Theoretical Prelude}

Although the jury's origins lie hidden in Dark Ages rituals, we can trace the origins of the sort of jury that concerns us here-the criminal trial jury-with something like pinpoint accuracy: The first true criminal jury trial seems to have taken place at Westminster in $1220 .^{16}$ Juries had long acted to resolve various civil disputes, especially claims about land, and they had for decades served as accusing bodies in criminal cases in the manner of modern grand juries. But not before 1220 did a jury sit in judgment of a criminal accused with the discretion either to acquit or to condemn.

The occasion of this sudden birth of trial by jury was the sudden death of trial by ordeal. ${ }^{17}$ Before 1215 , criminal trials had proceeded by ordeal or by battle. In the ordeal of cold water, the accused was tossed in a pool with a rope tied around his hips. If he sank, he was hauled out an innocent person, for the purity of the water had accepted him; ${ }^{18}$ but if the water repelled him and he floated, he was condemned. In the ordeal of hot iron, the accused walked barehanded with a hot iron bar. Three days later, when her bandages were removed, her healing hands revealed her fate: if the wounds were healing cleanly, she was absolved; if corruptly, condemned. ${ }^{19}$ In all events, the

16. See Roger D. Groot. The Early-Thurteenth-Centun Crumunal Jun: in Tweive Good MEV AND TRUE: THE CRIMINAL TRIal JURY IN ENGLAND. 1200-1800, at 3, 17-18 (J.S. Cockburn \& Thomas A Green eds., 1988) (hereinafter TwELVE GOOD MEN AND TRLE]. Al leust one histonan of the early jury his argued that the criminal trial jury could be seen in naseent form as carly as 1194-1195 See Cathanne Hamilton Kappauf. The Early Development of the Petty Jury in England: 1194-1221. at 153 (1973) (unpublished Ph.D. dissertation, University of Illinoss (Urbana-Champargn)) (on file with author). I thınk that Groot, who argues that the power to condemn distinguished the true criminal tmal jury from earlicr incamations, see Groot, supra, at 19, has the stronger position.

17. Scholars of the ordeal disagree about whether its death really was sudden Compare Paul R. Hyams, Trial by Ordeal: The Key to Proof in the Early Common Law, in ON THE LAws AND Clstows OF ENGLAND 90, 101 (Morris S. Amold et al. eds., 1981) (framing an argument that centunes-long socia! developments brought about the slow end of the ordeal), with ROBERT BARTLETT. TRIAL BY FIRE AND WATER: THE MEDIEVAL JUdiCIAL ORDEAL 42-43, 69-70, 100. 128 (1986) (arguing that the ordeal was "flourishing" in the 11 th and 12th centunes before being abruptly "abandoned" in (215) I think the stronger arguments favor the conclusion that the Church's actions in 1215 brought a thnving institution to a quick end.

18. Being cleared by the ordeal did not, however, mean that the accused would go free If. despite the ordeal's verdict, the defendant was regarded as guilty by common report, he would be sent into exile See Henry Charles Lea, Superstition and Force 400 (Philadelphia. Lea Brother \& Co th ed 1892) (citing the Assize of Clarendon of 1166).

19. See, e.g., BARTLETT, supra note 17. at I (describing the ordeal by hot iron). THOYAS AYDREW

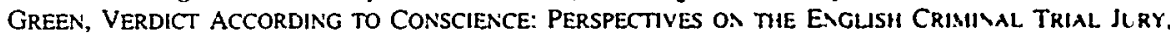
1200-1800, at $8 \mathrm{n} .18$ (1985) (describing both ondeals); Hyams. supra note 17, at 93 (describing both ordeals); Margaret H. Kert et al., Cold Water and Hot Iron: Trial by Ordeal in England. 22 J. INTERDisc. 
judgment was God's. But in 1215 the Church forbade priests to officiate at ordeals and suddenly stripped these rituals of their divine imprimatur. ${ }^{20}$ English and other European justice systems soon abandoned the ordeal in criminal cases. ${ }^{21}$ Though the Church took no action against trial by battle, that form of trial lacked the popular support needed to fill the role of the lost ordeals; too often, combat between accuser and accused ended badly for a worthy but weak litigant. ${ }^{22}$ Moreover, it was not always obvious who should do battle for the prosecution. ${ }^{23}$ Criminal justice systems throughout Europe, therefore, suddenly sought a new form of trial. ${ }^{24}$

In the familiar history of these events, the English turned to trial by jury, elevating an institution that once had served in lesser roles to be final arbiter of guilt or innocence. At the same time, the countries of the European Continent adopted the "rational" Roman-canon forms of proof, which exalted the probative power of sworn eyewitness testimony and of the accused's confession, often coerced through torture. ${ }^{25}$ Those commentators and historians who feel the English took the wrong road at this juncture sometimes argue that with trial by jury the English simply substituted one ordeal for another. They say that in trial by jury, as in the old ordeals, inscrutable

HIST. 573, 582-83, 588-89 (1992) (describing both ordeals). Kerr and her colleagues note that women were more often sent to the ordeal of hot iron, while men more often faced the ordeal of cold water. See Kerr et al., supra, at 582; see also infra note 78.

20. See Groot, supra note 16, at 3; see also Rebecca V. Colman, Reason and Unreason in Early Medieval Law, 4 J. INTERDISC. HIST. 571, 582 (1974) (noting that, after the introduction of Christianity, ordeals were usually conducted by clergy). Hence the Fourth Lateran Council of 1215-and not the Magna Carta of the same year, which had little to do with it-prompted the birth of the criminal jury trial in England. See Groot, supra note 16, at 10.

21. See BARTLETT, supra note 17, at 100 (citing an English law of 1219 and a Danish law of 1216).

22. See id. at 116 ("The idea that the justice of the cause was, therefore, the single relevant datum for victory ... was, perhaps, not always entirely convincing."). It is true that the weak could hire champions to do battle for them, but then trial by battle worked against the poor.

23. Before 1215, publicly initiated prosecutions, or indictments, were resolved by ordeal, while privately initiated prosecutions, or appeals, were tried by battle. See THE TREATISE ON THE LAWS AND CUSTOMS OF THE REALM OF ENGLAND COMMONLY CALLED GLANVILL $171-73$ (G.D.G. Hall ed. \& trans., Nelson 1965) (c. 1188) [hereinafter GLANVILL]. One-on-one combat may have appeared to be more appropriate to private than to public prosecutions.

Though unused since 1492, trial by battle survived on English statute books until 1819. See An Act To Abolish Appeals of Murder, Treason, Felony or Other Offences, and Wager of Battel, or Joining lssue and Trial by Battel, in Writs of Right, 1819, 59 Geo. 3, ch. 46; BARTLETT, supra note 17, at 122; see also ANTHONY MUSSON, PUBLIC ORDER AND LAW ENFORCEMENT: THE LOCAL ADMINISTRATION OF CRIMINAL JUSTICE, 1294-1350, at 169 n.4 (1996) (reporting that trial by battle became obsolete as early as 1300).

24. $C f$. 2 FREDERICK POLLOCK \& FREDERIC WILliam MAITLAND, THE HISTORY OF ENGLISH LAW BEFORE THE TIME OF EDWARD I, at 650 (Boston, Little, Brown, \& Co. 2d ed. 1899) ("The abolition of the ordeal had disturbed all [of the law's] arrangements.").

25. Although there is debate about what gave rise to judicial torture in continental Europe, compure JOHN H. LANGBEIN, TORTURE AND THE LAW OF PROOF 3-8 (1976) (arguing that strict Continental standards of proof made criminal convictions too difficult to obtain except by recourse to confessions coerced by torture), with Richard M. Fraher, Conviction According to Conscience: The Medieval Juris/s' Debate Concerning Judicial Discretion and the Law of Proof, 7 LAw \& HIST. REv. 23, 24, 29, 62-63 (1989) (arguing that judicial torture may have developed as a form of punishment, not proof, especially in hard-to-prove crimes), there seems to be no disagreement that a good number of confessions were extracted through torture. 
decisionmaking produced irrational results. ${ }^{26} \mathrm{I}$ agree that the criminal trial jury took on certain characteristics of the ordeals, but not those (or at least not exclusively those) complained of by the jury's critics. And I think there is more to be learned by looking at the useful attributes that these systems shared than by dwelling on the historical irony that one flawed system of adjudication succeeded another. By identifying the common features that enabled the ordeal and trial by jury to command people's respect, we may discover the essential attributes of a successful system of proof in the premodern world. In fact it may be impossible to understand even the later history of the criminal trial jury without a theory about why the ordeal worked so well and about what its demise left lacking.

This theory focuses on three common features of the ordeal and jury trial. The first shared trait-and the most fundamental-is the inclination to wrap the system's judgments in the word of God. The second trait, an elaboration on the first, is the tendency to rely most heavily on the divine sanction when the system's judgment would take the defendant's life or limb. The third is the need, in a world in which God rarely speaks clearly through either blistered hands or witnesses' words, to ensure discreet human control under the cover of divine judgment.

\section{A. Seeking Divine Sanction for Criminal Verdicts}

That the ordeal drew its legitimacy from the apparent intervention of God is a historical cliché, ${ }^{27}$ but probably true. Hence when the Church decertified the ordeal, it wrecked it, for the system no longer could claim that God-and not some mere human authority-had decreed the accused's guilt and authorized punishment. With the ordeal gone, the system must have sought out a substitute that would reassure the public of God's continuing role in meting out human justice. The old system of trial by ordeal bespoke a social humility, an unwillingness to take life or limb without divine sanction. The authorities could not have thought that the public would grow quickly vain about the adequacy of human judgment and transfer its faith from God's word to the word of mortals. ${ }^{28}$

26. See, e.g., LANGBEIN, supra note 25, at 77-78. see also BARTLET, supra note 17, al 139 ("[T]he inscrutability of the jury's verdict was reminiscent of ordeal procedure "). Colmun. supra note 20 , at 591 ("The modem veroict of the jury in perplexing eases often has all of the inserutability of a judgment of God .....").

27. See Colman, supra note 20, at 582 (notıng that ordeals" "outcomes wete interpreted as manifestations of divine judgment"): Hyams, supra note 17. at 92 (statıng that ordeals "purpori[ed] to work by revealing God's judgment").

28. See Jerome Frank, COURTS ON TRIAL: MYTH AND REALTY iv ANERICA J STICE 4 (1950) ("Leave to the inadequate judgments of mere human judges the tesing of the Inuth-lelling of witnesses, when life or property are at stake? By no means."): GREE, supra note 19. at 3. LAרGBEl supra note 25. at 6 ("It is almost impossible for us to imagıne how difficult It must have been for the ordinan people of that age to accept that substitution. ... 'You who are merely another mortal like me. who are you to sit 
The clearest evidence of the system's sense of illegitimacy in the early years after the ordeal's death was its failure to force trial by jury upon those accused of crime. One had to consent to jury trial. ${ }^{29}$ The prisone forte $e t$ dure-literally "harsh and long imprisonment"-was the system's way of compelling "consent." This institution was established by statute in 1275, ${ }^{30}$ but may have existed since the jury trial's very earliest days. ${ }^{31}$ An early observer described it this way:

And if they will not put themselves upon their acquittal [that is, elect trial], let them be put to their penance, until they pray to do it; and let their penance be this, that they be barefooted, ungirt and bareheaded, in the worst place in the prison, upon the bare ground continually night and day, that they eat only bread made of barley or bran, and that they drink not the day they eat; nor eat the day they drink, nor drink anything but water, and that they be put in irons. ${ }^{32}$

In later times the prisone took a new name-the peine forte et dure-and a more sinister form-placing heavy weights on prisoners' chests until they either elected jury trial or died. ${ }^{33}$

The peine forte et dure survived on the books, if not in practice, until the eighteenth century. ${ }^{34}$ Its existence discloses as eloquently as anything could

in judgment upon me?'"). James Fitzjames Stephen noted that the author of the Mirror complained during the reign of Edward I (1272-1307), "It is an abuse that proofs and purgations be not by the miracle of God where other proof faileth." 1 JAMES FITZJAMES STEPHEN, A HistoRY OF THE CRIMINAL LAW OF ENGLAND 253 (London, MacMillan 1883) (quoting article 127 of the Mirror).

Barbara Shapiro's solution to the historical paradox-that the jurors' personal knowledge of the facts gave them a "special, near divine, spark"-seems unsatisfying. BARBARA J. SHAPIRO, "BEYOND Reasonable DoubT" and "Probable Cause": Historical PERspectives on the anglo-American LAW OF EVIDENCE 241 (1991).

29. In contrast, under the pre-1215 law, a person refusing to submit to the ordeal could be put to death. See 2 POLLOCK \& MAITLAND, supra note 24, at 650.

30. See The Statute of Westminster, the First, 3 Edw., ch. 12 (1275); 2 Pollock \& MAITLAND, supra note 24 , at $651-52$.

31. Groot believes the prisone forte et dure began in the 1220s, see Groot, supra note 16. at 20 n.71, $35 \mathrm{n} .157$, but his evidence is slim. It is unclear how the system dealt with persons who refused to plead before 1275. Bracton wrote in the 1250 s that the defendant would "remain undefended and quasi-convicted." 2 HENRY BRACTON, ON THE LAWS AND CUSTOMS OF ENGLAND 390 (Samuel E. Thorne ed. \& trans., Harvard Univ. Press 1968) (c. 1250).

32. Britton: AN ENGlish Translation and Notes 21-22 (Francis Morgan Nichols ed., 1901) [hereinafter BRITTON]. Although of uncertain authorship, this late-13th-century treatise is commonly attributed to Britton. See id. at viii-xi.

33. See GREEN, supra note 19, at 15. Prisoners sometimes held out until death because the government could not seize their lands without a criminal conviction. In the case of high treason, however, the accused who refused to plead was condemned as if convicted. See EDIVARD COKE. THE THIRD PART OF THE INSTITUTES OF THE LAWS OF ENGLAND 217 (London, E. and R. Brooke 1797). For a brief history of the peine forte et dure, see H.R.T. Summerson. The Early Development of the Peine Forte et Dure, in LAW, Litigants, AND THE Legal Profession 116, 116-25 (E.W. Ives \& A.H. Manchester eds., 1983).

34. In 1692, a suspected wizard was pressed to death in Salem. See 1 THE SALEM WITCHCRAFT PAPERs 26-27 (Paul Boyer \& Stephen Nissenbaum eds., 1977). Peter Linebaugh cites a casc from 1721. See Peter Linebaugh, The Tyburn Riot Against the Surgeons, in ALBION's FATAL TREE 65, 111 (Douglas Hay et al. eds., 1975). But examples so late are rare. In 1772, Parliament deemed refusals to plead to constitute guilty pleas. See An Act for the More Effectual Proceeding Against Persons Standing Mutc on 
how acutely the loss of the divine sanction embarrassed the criminal justice system-and how suspicious the English remained about the legitimacy of human judgment. A student once remarked of today's search and seizure law that "consent is what you get when you don't have probable cause." medieval England, the need to win the prisoner's consent to trial by jury betrayed the system's felt lack of legitimacy. As I will argue in Parts II and III, the system responded to this crisis of legitimacy by exalting a different source of divine sanction for the verdicts of its very human juries: the witness's oath, enforced (as it was thought to be) by the threat of divine vengeance. ${ }^{36}$

It would be surprising if this crisis of legitimacy had been peculiar to the English. Continental justice systems also had staked their claims to legitimacy in part on the divine sanction of the ordeal. Indeed, one can see in the "rational" rules of proof adopted on the Continent after the fall of the ordeal" evidence of an impulse to exalt the oath that was much like that in England. Charles Donahue paraphrases Tancred's treatise from around 1215, which explained what a Continental judge should do when confronted with a conflict between two sworn witnesses:

[T] he judge ought to attempt to reconcile their statements if he can. If he cannot, then he ought to follow those who are most trustworthy-the freeborn rather than the freedman, the older rather than the younger, the man of more honorable estate rather than the inferior, the noble rather than the ignoble, the man rather than the woman. Further, the truth-teller is to be believed rather than the liar, the man of pure life rather than the man who lives in vice, the rich man rather than the poor, anyone rather than he who is a great friend of the person for whom he testifies or an enemy of him against whom he testifies. If the witnesses are all of the same dignity and status, then the judge should stand with the side that has the greater number of witnesses. If they are of the same number and dignity, then absolve the defendant. ${ }^{38}$

Donahue's interpretation of this elaborate method, which so sharply limited the judge's discretion to act as lie detector, is particularly revealing. For the

Their Arraignment for Felony, or Piracy, 12 Geo. 3, ch. 20 (1772) In 1827, I decmed refusals to be pleas of not guilty. See An Act for Further Improving the Administration of Justice in Cnminal Cases in England, 1827,7 \& 8 Geo. 4 , ch. 28.

35. My colleague Barbara Babcock passed this on to me

36. Cf. Colman, supra note 20, at 587 ("It should be emphasized that all forms of medieval proof were considered dependent upon God's judgment, and that perjury at any stage of the proceedings was fully expected to bring its own punishment.").

37. See Barbara J. Shapiro, Probability and Certaivts is Severteerthi-Clith ky Evglavd 173 (1983) (explaining that many secular jurisdictıons on the Contınent adopted canonist procedures that were considered to be more rational).

38. Charles Donahue, Jr., Proof by. Witnesses in the Church Courts of Aledicial England An Imperfect Reception of the Learned Law, in ON THE LAWS AND CLISTOMS OF ENGLAND. supra note 17. al 131 
system to abandon the judgment of God for the judgment of mortals, he writes,

it was necessary for people to believe-and perhaps even for it to be true-that the ultimate decision of the case not be within human discretion but be dictated by the rules of law. People might accept a judgment of the law rather than a judgment of God; it was less likely that they would accept a judgment of man rather than one of God. ${ }^{39}$

I would push Donahue's analysis one step further. The point of Tancred's series of rules was not to substitute the power of law for the hand of God, but to maintain insofar as possible the power of God, as expressed through the oath. The first of Tancred's rules was that the judge should try to reconcile conflicting oaths-and hence avoid conceding that the oath is any less than a divine guarantor of truthful testimony. The next series of rules merely established a hierarchy of oaths and provided that weightier oaths would defeat lesser oaths. For the most part, the Roman-canon law avoided even this much uncertainty by barring altogether "the testimony of those who were unlikely to tell the truth": ${ }^{40}$ slaves, women (in certain circumstances), those below the age of fourteen, the insane, the infamous, paupers, infidels, criminals, parties to the cause, children of parties, parents of parties, servants of parties, and enemies of parties. ${ }^{41}$ Tancred's third principle-that if the oaths are of equal status, the greater number of oaths should prevail-and his fourth principle-that if the oaths are equal in both status and number, the defendant must go free-were clear expressions of the primacy of the oath. They placed no discretion in either human judges or human laws, but retained all power in God.

We will see shortly that by the late seventeenth century, English evidence rules roughly tracked Tancred's treatment of the problem of conflicting oaths. One rule was that, when possible, juries should reconcile conflicting oaths to avoid calling either witness a perjurer-this was the principle of Bethel's Case. ${ }^{42}$ A broad series of competency rules helped to avoid the problem of conflicting oaths by forbidding the testimony of those thought most likely to lie. When both Bethel's rule and the competency rules failed to prevent a conflict in oaths, the jury was (according to some authorities) to prefer the testimony of the greater number of witnesses. At an earlier stage, before and

39. Id. at 133. Richard Fraher believes that Donahue is taking Tancred's principles too much at face value. He argues that there were in reality several mechanisms by which judges recaptured the discretion that inflexible rules seemed to take away. See Fraher, supra note 25, at 56-62. Fraher sees these mechanisms as evidence of faith in human judgment. See id. at 57. It is possible, though, that the system profited by maintaining a rigid set of rules that seemed to deny human discretion while in fact permitting much discretion in practice. See infra notes 81-82 and accompanying text.

40. Donahue, supra note 38 , at 132.

41. See id. at 130-31. The last several categories were all eligible to testify against their sympathics: children, for example, could testify against their parents. See id.

42. THE TRYAL OF SLINGSBY BETHEL ESQ., supra note 14, at 9; see infra Section III.A. 
through the mid-sixteenth century, English law protected the power of the oath even more completely: By forbidding defense witnesses in serious criminal cases altogether, it virtually assured that the accuser's oath would not be contradicted.

In arguing that an emphasis on the power of the oath permitted the jury trial to replace in some measure the divine sanction once supplied by the ordeal, I do not mean to claim that there was a seamless iransfer of divine legitimacy from ordeal to jury trial. The very existence of the prisone forte et dure suggests otherwise, for if early jury trials could have claimed the divine cachet of the ordeal, there would have been no need to demand the defendant's consent to trial. Nor do I mean to argue that any systemic actor affirmatively went out in search of a new source of legitimacy and settled upon the witnesses' oaths. It is enough to say that the history of the ordeal suggests that systemic actors from King to county sheriff preferred to present criminal verdicts to the community as divinely ordained. After the ordeal's demise, if only gradually and over time, the institutions of justice gravitated toward a formula for the jury trial that permitted the system to reassert its old claim to divine legitimacy. ${ }^{43}$

There is little reason, then, to expect that the jury trials that rose up within several years after the passing of the ordeal should immediately have aken on the early-modern form centered on witnesses and their oaths. Indeed, many historians argue that the early criminal trial jury had very little to do with witnesses sworn by divine oath and had instead a rather human face. The early jury, they say, was composed of "Men of the Neighbourhood," who hailed from the community of the crime and either witnessed the crime themselves or spoke with those who had-and who "came to court more to speak than to listen." Though the scant trial records of those early years"s make it hard

43. I cannot explain the Enghsh attraction to the oath over other concesable sources of dune legitimacy. Oaths, as Wigmore noted, played a prominent role in Saxon umes. when the) were "cfficzerous

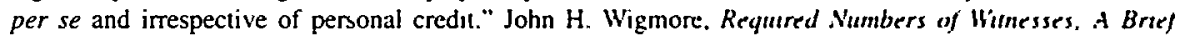
History of the Numerical System in England. I5 HARV L REI 83. 88 (1901). ser also 9 WS HOLDSWORTH, A HISTORY OF ENGLISH LAW 204 (1926). The English mas have inhented a reverence for the oath from the Roman-canon law, which governed in English ecclesiasucal couns and at umes had treated oaths as conclusive proof. See R.H. HELAHOLZ. THE SPIRIT Or CLASSIC AL C +1 No LAW 1.45-73 (1996). There is clear evidence in other contexts that the common law borrowed Roman-canon law forms See, e.g., 2 W.S. HOLDSWORTH. A HISTORY OF E.IGLISH LAW 204-06. 267.86 (3d ed 1923) (hereinafter HOLDSWORTH 3d ed.]; SHAPIRO, supra note 28, at 187.90.

For my purposes here. it is not necessary to decide exactly what question the ordeal and inal jury were answering. Rober Palmer's strking argument that both the ordeal and the carly tnal jun made moral judgments of culpability and not factual judgments of guilt, see Robert C Palmer. Comscternce and the Las The English Criminal Jun: $84 \mathrm{MrCH}$. L. REv. 787. $792-94$ (1986). does not bear on my questuon whether the source of authority behind that judgment was percessed to be human or dusne

44. LANGBEIN, supra note 25. at 78: see also. e g. I HoLDSW ORTM 30 ed. supra note 43, at 333. 34 . 1 STEPHEN, supra note 28, at 426: 2 JOHI HENRY WIGMORE. A TREATISE ON MIE AYGLO-AMLRIC 4 SYSTEM OF EVIDENCE IN TRIALS AT COMMO LAll $\$ 575$. at 676 (3d ed 1940)

45. See MUSSON, supra note 23, at 189 (noung the "sparseness of referenees concerning jury personnel" in the records): 2 POLLOCK \& MAITLAND. supra note 24, at 653 "“The curt brevily of our records allows us to say but little."); Edward Powell. Jun Trial at Gaol Deluen in the Late buddle Ages 
to confirm or rebut this theory of the "self-informing" criminal jury, on the whole they incline the reader to doubt that the early jury was entirely selfinforming, in the sense that it received no information from witnesses in court. One finds little affirmative evidence that witnesses were absent from early courtrooms ${ }^{46}$ and a fair amount of evidence that witnesses were present and gave evidence, at least occasionally. ${ }^{47}$ Those historians who have embraced

The Midland Circuit, 1400-1429, in TwELve GOOD MEN AND TRUE, supra note 16, at 78, 81 ("Medicval legal records are notoriously uninformative about trial procedure.").

46. Traditional proponents of the theory of the self-informing jury have relied heavily on argurnents from silence: As contemporary chroniclers said nothing of witnesses, there must have been nonc. But arguments from silence are always treacherous. For one thing, most medieval case reports are simply too short to shed much useful procedural light. A typical trial record might be this brief: "Celestria of Hatton [above Aune], taken on suspicion of robbery, puts herself on the neighborhood [elects a jury trial] for good and ill. The jurors say that she is not guilty and therefore she is quit therein." ROLLS OF THE JUSTICES IN EYRE: BEING THE ROLLS OF PLEAS AND ASSIZES FOR GLOUCESTERSHIRE, WARWICKSHIRE AND STAFFORDSHIRE 623-24 (Doris Mary Stenton ed., Bernard Quaritch 1940) (1221-1222) (hereinafter GLOUCESTERSHIRE ROLLS]. For another, silence is always ambiguous: "[E]ven in the nineteenth century, the formal 'record' will say no word of any witnesses and will speak as though the jurors had agreed on a verdict before they came into court." 2 POLLOCK \& MAITLAND, supra note 24, at 628.

47. Scattered records of early jury trials specifically mention the testimony of witnesses. See. e.g., ROLLS OF THE JUSTICES IN EYRE: BEING THE ROLLS OF PLEAS AND ASSIZES FOR YORKSHIRE IN 3 HENRY III, 1218-1219, at 300 (Doris Mary Stenton ed., Bernard Quaritch 1937) (1218-1219). I thank Dan Klerman for this reference. See also 9 HOLDSWORTH, supra note 43, at 183-84 (citing early examples of the use of witnesses, including a murder trial from 1235).

The procedural forms of the private prosecutions known as "appeals" suggest a stronger role for witnesses than historians generally have allowed. To launch an appeal, the appellor had to claim (whether it was true we cannot be sure) that he was "ready to prove by his body [by combat] as one who was present and saw and heard this." Kappauf, supra note 16, at 184, 197 (quoting LINCOLNSIIRE AND WORCESTERSHIRE PLEAS 544 (Doris Mary Stenton ed., Bernard Quaritch 1934) (1218-1219, 1221)). The reports of some such cases, although ambiguous, support the supposition that the jury heard testimony not merely from the appellor, but from other witnesses as well. See, e.g., 2 BRACTON, supra note 31, at 406 (noting that the sheriff and coroners may testify about whether an appellor raised the hue and cry and about the appellor's wounds); Kappauf, supra note 16, at 180-81 (quoting GLOUCESTERSHIRE RoLLS, supra note 46, at 413-14). In the earliest court sessions after the abolition of the ordeal, appeals accounted for more than a third of all serious felony prosecutions, raising the very real possibility that in many criminal jury trials, an eyewitness was present in court and spoke to the jury. See id. at 66.

Moreover, Robert Palmer notes that civil trial juries were hearing evidence as early as the 1290 s. See Palmer, supra note 43, at 796. He argues that it "would be both surprising and interesting" if criminal trial juries did not begin hearing witnesses for another 200 years, as traditional historians argue. $/ d$.

We also should not ignore the use of witnesses in non-trial settings. Stephen cited a case from 1221, in which "several . . . who were present when [the victim] was killed, testified that they saw" the defendant holding the weapon. I STEPHEN, supra note 28, at 259-60. Thayer, as well as Pollock and Maitland, criticized Stephen's reliance on this case because it was not strictly a trial, but a proceeding to determine whether the defendant, as a manifest slayer, should be condemned without trial. See JAMES BRADLEY THAyer, A Preliminary TREatise on EVIDENCE at THE Common LaW 13 n.l (Boston, Little, Brown \& Co. 1898); see also 2 POLLOCK \& MAITLAND, supra note 24 , at 654 n.4. But whatever the formal denomination of the proceeding, it demonstrates that authorities turned to cyewitnesses when hoping to learn the truth about a past event.

One final piece of evidence gives cause to doubt the traditional theory. If the early trial jury truly was self-informing, then it is at least a little puzzling that the defendant had the right to challenge trial jurors for cause-and even to have all of them removed, see 2 BRACTON, supra note 31, at $405-$ a right that would have held out to the defendant the power to scuttle trial altogether unless other informed jurors waited nearby. This difficulty grew larger by the end of the 13th century, when Britton suggested that the defendant could of right challenge any juror who had served on the presenting jury. See BRITTON, supra note 32 , at 25 . The most recent evidence suggests that, in the early 14 th century, challenges "were more commonly employed ... than has hitherto been assumed." MUSSON, supra note 23, at 189, 195-97. But see J.B. Post, Jury Lists and Juries in the Late Fourteenth Century, in TWELVE GOOD MEN AND TRUE, 
the theory of the self-informing jury perhaps have focused too heavily on early civil juries, which almost certainly were self-informing, although there is good reason to think that criminal juries would not have mimicked their civil counterparts in this regard. ${ }^{48}$

On the other hand, it would be rash to suggest that early trial jurors came to court entirely ignorant of the facts in the manner of modern jurors. The mechanics of pretrial and trial procedure made it likely that at least some jurors had at least some knowledge of the event or the defendant before

supra note 16, at 65, 71-72 (arguing based on late-14th-century evidence thal defendants were not permilted in practice to challenge jurors). Of course. as Thomas Green argues, even if only a feu preinformed jurors remained on a panel, those few could have informed the rest See Thomas $A$. Green. A Retrospective on the Criminal Trial Jury, 1200-1800, in TWELVE GOOD MEN AND TRL'E, supra nole 16, at 358. 365. 367-69. 373.

48. Almost all of the frequently cited examples of civil junes acting on their own knowledge concerned one of these four grounds of dispute: the value or ownership of land. the despoilation of land by nuisance or waste, the relationship between a deceased and a clamed hetr, or the age of a party Such suits were authorized by ordinances of Henry Il, the earliest of which dates 101164 . See 1 POLLOCK \& MAITlAND, supra note 24, at 149-50 (discussing Henry's ordinances): Kappauf, supra note 16. al 69-70 (same). A number of authorities discuss suits conceming the value or ownership of land See. eg. 2 BRACTON, supra note 31, at 143-45, 214-15 (citung the use of a jun to delermine the value of land). WILLIAM FORSYTH, HISTORY OF TRIAL BY JURY 124, 152-53 (New York. Cockcroft \& Co 1878). GLANVILL, supra note 23, bk. XIII, at 150. 157: I POLLOCK \& MAITLAND. supra note 24, at 93 (desenbing a suit from early Norman times decided by verdict of English jurors who knew how the disputed lands lay in the time of King Edward); I REEVES HISTORY OF TIE ENGLISH LAW 398 (WF Finlason cd. Philadelphia, M. Murphy 1880) (hereinafter ReEvES]: I STEPHEN, supra note 28. at 255-56. THAYER. supra note 47, at 91 (citing a 1374 case). On suits about nussance or waste. see, for example. BrtTrov, supra note 32, at 244-45; and 2 POLLOCK \& MAITLAND, supra nole 24, at 619-20. On inhentance suits, see, for example, GLANVILL, supra note 23, bk. II, at 27: $d$ l. bk. Xlll, at 150. I POLLOCK \& MATLA ND, supra note 24, at 148; 2 id. at 76; and I REEVES, supra, at 395. On disputes about a person's age, see, for erample. GLANVILL, supra note 23, bk. XIII, at 159-60: 1 STEPHEN, supra notc 28. at 262-63. and THAYYR. supra note 47, at 20-21. See also GLANVILL, supra note 23, bk. XIII. at 150-51 (descnbing a suit concerning a person's date of death).

These questions had one thing in common: Each tumed on facts that uere well withtn the observation of many members of the community. See Kappauf. supra note 16. at 70. Other questions presented to junes fit this description. Thayer relied on a case from 1158 in which jurors were asked what the defendant's market rights had been during the last king's retgn. See THAYER, supra note 47. at 53-54 Pollock and Maitland reported that jurors were called upon during the Conqueror's reign to tell hum what the law was during the reign of Edward. See 1 POLLOCK \& MAMLAND, supro note 24, at 103.

Even a rational designer of social systems might propose to answer such questions by calling together a dozen neighbors to say what they knew. Criminal cases, in contrast. presenied an entirely different kind of factual dispute. As crimes tend to be ephemeral and witnessed only by a few, the only way to learn about a crime (absent sophisticated forensics or a confession) is to ask one of those fet tho happened to see it. There is no reason to think that early legal authonties faled to grasp this distunction between the trial of a land dispute and the trial of a crime. Indeed. one of the fer histonans to focus on the different forms of dispute found that, when land, age, or birth was at stake. jurors tended to come from the local community (and hence were more likely to be "self-informed"). whereas "|c|nminal tnal jurors were less likely to originate from one locale." George Stephen Sipek. Five Studies in the Early History of the Jury 4-5, 7-8 (1976) (unpublished Ph.D. dissertation. University of Chicago) (on file with author). see also id. at 11-12 (noting that local jurors were also called to decide whether someone had been a particular master"s serf).

One can find very few old reports of criminal cases in which jurors uere specifically chosen because of their familiarity with the facts. Powell mentions two such cases. One of these involved an offense committed in open court, the other a theft of financial documents-an offense that arguably required factinders with specialized knowledge. See Powell, supra note 45 , at 80 . These were, as Powell noles. "exceptional" cases. Id. We should not conclude from them how the typical. largely private crine was ined 
trial. ${ }^{49}$ For my purposes, the more important question is not what the jurors knew beforehand, but what they learned in court - and whether the process of transferring information to the jury in court might have given cause to claim that the jury's verdicts were somehow divinely ordained. Even fast adherents of the old theory have allowed that early juries might not have been entirely self-informing. They acknowledge that juries might have collected at least some of their evidence from witnesses in the modern fashion. ${ }^{50}$ And although traditionalists had once supposed that the criminal trial jury remained self-informing as late as the sixteenth century, more recent studies suggest the jury had ceased to be entirely self-informing, if it ever was, within about a century of its birth. ${ }^{51}$

49. Thomas Green argues that most trial juries included at least a small number of local jurors and that those few "may well have dominated proceedings." Green, sıpra note 47, at 365, 367.69, 373. Moreover, he says elsewhere, most trial juries also included some men of status, who, although "not likely to have firsthand knowledge of slayings and thefts, ... were well positioned to make inquirics." GREEN, supra note 19, at 17; see also infra note 55 .

50. Green, who once suggested that the early trial jury was entirely self-informing, see GrEEN, supra note 19 , at 26-27, has more recently written that "[t]here must have been some, perhaps many, cases in which inculpatory evidence came forward during" trial, Green, supra note 47 , at 363 . Green resists the conclusion that such evidence was "common," at least in the trial jury's earliest years, but adds that our evidence is so thin that "[i]t is perhaps unsound to conclude in either direction." Id. at 370 . At all events. he says, "the opportunity for self-informing was always present in the Middle Ages," perhaps alongside other sources of evidence. Id. In correspondence with the author, Green has proposed the term "preinforming" as a substitute for "self-informing." Letter from Thomas Green, Professor, University of Michigan Law School (Sept. 6, 1997) (on file with author). The former term suggests that the trial jury came to court with some information in hand, but does not imply that no more information was forthcoming in court.

51. This evidence appears in the work of several current historians of the early trial jury. Anthony Musson reports the most direct evidence that early-14th-century juries heard witnesses in court. See MUSSON, supra note 23, at 189 . He finds at least occasional examples of a seemingly modern panoply of evidence produced before criminal trial courts, including both prosecution and defense witnesses, statements by the accused, witnesses to the defendant's reputation, and physical and documentary cvidence. Public officials sometimes served as prosecution witnesses, and at least in one circumstance-prison break-the case could not go forward without official testimony. See id. at 201-05. Musson concludes that in the early 14 th century,

the self-informing character of trial juries was tempered by the recognition that witnesses and some form of evidence were an acceptable and sometimes essential part of medieval criminal trials. This was especially so in cases where the circumstances were unclear and the jury lacked the knowledge to be truly self-informing.

Id. at 205.

Other recent scholarship approaches the problem indirectly, by challenging the belief that criminal trial jurors were "men of the neighbourhood," who brought local knowledge of the crime with them to court. For example, Bernard William McLane's study of a special court session in Lincolnshirc in 1328 reveals that criminal trial jurors were drawn from the county at large and "rarely . . . lived at the scene of the crime and only infrequently came from the villages within five miles of the scene." Bernard Willian McLane, Juror Attitudes Toward Local Disorder: The Evidence of the 1328 Lincolnshire Trailbaston Proceedings, in TWELVE GOOD MEN AND TRUE, supra note 16, at 36, 56-57.

J.B. Post reports mixed findings in his study of late-14th-century jury lists. On the one hand, a fairly great proportion of jurors in the late 14th century came from the same hundred (a sub-county gcographical district) as the crime. See Post, supra note 47 , at 69 . On the other hand, only about half of those summoned for jury duty showed up. Officials apparently had to gather the balance of the panel from bystanders. In fact, because jurors were so unlikely to show up, sheriffs took to summoning persons who had other business in the court. There is little reason to think such persons came to court with any knowledge of the crimes to be tried. See id. at $65,67-68,70-73$. 
As for those first hundred years, we can do little better than guess at the system's source, if any, of divine legitimacy. Perhaps the jurors' own oaths, combined with their claimed status as witnesses, filled the part that the oaths of true witnesses played in later years. Or perhaps, contrary to the theory of the self-informing jury, jurors really did hear witness testimony much as they did later. Or perhaps there was a period of transition during which a system that had lost its claim to the divine legitimacy of the ordeal clumsily felt its way toward a reconfigured trial process that let it stake that claim anew. The prisone forte et dure is evidence of such a clumsy transition.

We need not now unravel the mystery of those first hundred years. By the middle of the fifteenth century, as the writings of John Fortescue make plain, the English trial system had come to stake great importance on the evidence of witnesses sworn under oath. ${ }^{52}$ And as we will see in Part II, by the middle of the sixteenth century, when the historical record first lets us see the shape of criminal jury trials with any clarity, a form of trial was in place that exalted the power of the oath to reveal the truth and permitted the system to reassert its claim to divine sanction for its verdicts.

\section{B. The Special Case of Capital Convictions}

Although the jury trial system, like the ordeal before it, sought to present its verdicts to the public with a divine imprimatur, in both systems there were certain decisions that seemed to require a merely human say-so. Human

Edward Powell has concluded that jury panels in the Midland circuit in the early 15 th centun did not regularly include more than one or a few jurors from the sime hundred as the crine-and a hundred included dozens of towns. See Powell, supra note 45. at 85-88 Sometumes not a single juror came from the same hundred as the crime. Even within hundreds, there was no consistent attempl to gel jurors from the same location as the offense. See id. Powell argues that, as junes regularly heard more than one case. and as those cases could originate anywhere in the county (and as mosl countues were quite large). It was almost impossible that jurors could have visited cnine scenes to question witnesses See id at 96-97 He also notes affimative evidence of the use of witnesses. Al least b) the early 15 th centun. cnme vicums were an integral part of criminal prosecutıons. After indictments issued, the shenff would make a proclamation for all those wishing to prosecute or having informilion to come forward Ser id. at 107.08 He hypothesizes based on suggestive, though not overuhelming. cvidence that constables and other law officers gave evidence before early junes. See $t d$, at $110-11$.

Powell acknowledges evidence on the other side. He allows that the geographical correlation betucen crime and jurors was stronger when there were only one or two cases to be tned-indicating pertaps an aspiration to have local jurors. See id. at 82-88. And he notes that coroners. basliffs, and constables served frequently as jurors, lending some support to the idea that jurors invesligated conmes before tnal See $u d$ at 90-94; see also MUSSON, supra note 23, at 190-91 (reporing similar findings). Pow ell seems to believe. however, that these men were selected for their status, not their knouledge. See Poucll. supra note 45 , at 96-97. And based on the whole of his evidence, he draws a sweeping conclusion about the theory of the self-informing jury: "My suspicion is that criminal tral junes were never enurely self-informing in the stnct sense in which the term has been interpreted. and that even in the earliest days of jury inal, accusers and witnesses had the chance to inform the jury in court." $/ d$. at 115-16.

52. At least in the civil context, the use of swom witnesses was already highly elaborated by Fortescue's day. He described the process of sequestenng witnesses. "so that the evidence of one of them shall not instruct or induce another to testufy in the same manner" JOH FORTESCLE. DE LAL DIBL S LEGL 4 ANGLIE 61 (S.B. Chrimes ed.. 1942). Stephen concludes that Fortescue wrote belween 1.460 and it70 See I STEPHEN, supra note 28, at 263. 
authority was sufficient, first of all, for an accusation: At least since the Assize of Clarendon of 1166 , the jury of presentment returned indictments against those rumored to be criminals. ${ }^{53}$ As its delegated task was to report what people said about others ${ }^{54}$ the presenting jury perhaps relied on unsworn (and very human) chitchat and innuendoes. ${ }^{55}$ Moreover, for decades before the Church disavowed the ordeal in 1215, human juries could render final verdicts in criminal cases: By declaring that the defendant, although "accused," was "not suspected," the presenting jury could spare him the rigors of the ordeal. ${ }^{56}$ In a similar way, defendants who were brought to bar by a private accusation known as an "appeal" could plead that the appeal had been made from hate and spite-de odio et atia-and ask a jury to decide the issue. If the jury agreed, the accused would escape the ordeal. ${ }^{57}$

But "while these juries could almost acquit, they could not convict."58 That is, although human authority was sufficient to adjudge the defendant's innocence and protect her from corporal punishment, the power to adjudge guilt in the face of uncertainty was purely divine. It is true that cases of

53. See Groot, supra note 16, at 5. Indictments represented but a part of the business of the presenting jury. Among other functions, the jury reported appeals (private criminal prosecutions) to the court. See Kappauf, supra note 16 , at 70-71.

54. See 2 BRACTON, supra note 31, at 403-04. The relevant standard, as Bracton wrote, was "popular rumour." Id. at 403.

55. In this sense, the presenting jury was clearly self-informing. What is more, crime victims sometimes served on presenting juries and presumably offered their personal knowledge of the facts. See MUSSON, supra note 23, at 178-79.

Some historians point to the overlapping memberships of presenting and trial juries as evidence that trial juries, too, were self-informing. Thomas Green makes this argument with respect to the "carly period" of the trial jury-the first half-century or so after its birth. See, e.g., Green, supra note 47, at 370 . As Green notes, however, procedural changes soon reduced the likelihood of an overlap between presenting and trial juries. See GREEN, supra note 19, at 20-22. The most recent evidence suggests that, at least by the carly 14th century, defendants often exercised their right to challenge prospective jurors, see MUSSON, supra note 23 , at 189, 195-97, with the result that most trial juries included several members-and often a majority-who were not members of the presenting jury, see id. at 198-99 (reporting evidence from 1326). See also BRITTON, supra note 32, at 25 (suggesting in the late 13th century that defendants' challenges of trial jurors who served on presenting juries should be allowed). After legislation of 1352 established the general principle that membership of presenting and trial juries should be separate, challenges on this basis became unnecessary. See MUSSON, supra note 23, at 197, 200-01.

There are two other reasons to question the view that the self-informing nature of the presenting jury is evidence that the trial jury was self-informing. First, when the criminal charge originated with a private party's appeal and not with the presenting jury's indictment, the presenting jury merely notified the court of the existence of the appeal and had, for all we know, no knowledge of the underlying facts. See 2 BRACTON, supra note 31, at 402-04 (noting that the appeal itself, even if abandoned by the person bringing the charges, can substantiate an indictment); Kappauf, supra note 16, at 138 .

Second, as Dan Klerman has pointed out to me, even when defendants were presented based on rumor and suspicion, the presenting jury might not have been available to try them. Records of 13th-century jail deliveries suggest that defendants were often indicted long before the trial court met and that the presenting jury had long since disbanded by the time of trial. Such cases might have constituted a majority of felony trials even by the 1240s and almost all felony triais by the 1290s. See Letter from Daniel Klerman, Professor, University of Chicago Law School (Dec. 8, 1996) (on file with author); see also MUSSON, supra note 23 , at 197 (noting that the presenting jury probably had disbanded by the time of jail delivery, but reporting evidence that "an overlap [between presenting and trial juries] may still have existed").

56. See Groot, supra note 16, at 6-8.

57. See id. at 8-9.

58. Id. at 9 . 
manifest guilt-where the defendant had confessed, for example, or was taken in possession of stolen goods-could proceed directly to condemnation. ${ }^{59}$ When the evidence was uncertain, however, human judgment was insufficient to support a verdict of guilt and the sentence of mutilation or death that, barring a pardon, inevitably would have followed. ${ }^{60}$ Here we see a premodern notion that death is different: Only God's judgment, as revealed through the ordeal, could condemn. ${ }^{61}$

If, as seems probable, this singular status of the ultimate punishment survived the ordeal, it might account for a peculiar inconsistency in the rules regarding sworn witnesses that prevailed throughout the early-modern era. Until 1702, criminal defendants in felony trials generally could not call sworn witnesses. ${ }^{62}$ Yet criminal defendants in misdemeanor cases, as well as both plaintiffs and defendants in civil cases, could call sworn witnesses. Although conflicting oaths were almost impossible in felony cases, therefore, they must have occurred fairly often in misdemeanor and civil cases. This is not to say that the system was indifferent to the prospect of conflicting oaths in these other cases: Many of the same rules that guarded against open conflicts of oaths in felony trials, including the web of competency rules and Bethel's rule, ${ }^{63}$ operated with full force in misdemeanor and civil cases. In misdemeanor cases, as in felonies, defendants could not give sworn testimony. Yet in these other cases the system must have been somewhat less averse to the prospect of a jury choosing between sworn witnesses, for it ultimately permitted such swearing contests to occur.

This distinction between felony cases and all others reflected, I suggest, the belief that a jury's merely human choice between two sworn witnesses was insufficient to support a judgment of death. Felonies, after all, were those crimes that carried the capital sanction. ${ }^{64}$ If, in the liturgy of the ordeal, only divine sanction could justify the ultimate punishment, then we can expect the same might have been true in the liturgy of the jury trial. And in the liturgy of the jury trial, only the unopposed oath of a sworn witness carried the divine sanction. Human mediation of conflicting sources of God's truth would have been an obvious oxymoron.

It is not easy to find this understanding that death was different expressed in so many words by contemporaries. Yet we do find it exactly where we

59. See id. at 6 .

60. See GREEN, supra note 19, at 11, 13-14. An adverse verdict by the presentung jury. however, meani that the accused had to leave the country even if the ordeal tumed out favorably. See Groot. supra note 16. at $7,8 \mathrm{n} .15$.

61. See 2 POLLOCK \& MAITLAND, supra note 24, at 650 (positung a communal feeling that "mere human testimony is not enough to send a man to the gallows").

62. See 1 Anne, ch. $9, \S 3$ (1702) (allowing defense witnesses in any felony tnal to be swom).

63. See infra Section III.A.

64. See Thomas A. Green, Societal Concepts of Crimunal Labiling for Homicude in Mediaeval England, 47 SPECULUM 669, 671 (1972) (noting that the penalty for felony convictions in the Middle Ages was invariably death). 
might expect-in the debate surrounding what was probably the earliest proposal to permit sworn defense witnesses in felony cases. ${ }^{65}$ As Parliament weighed such a proposal in 1607, the Earl of Salisbury objected that sworn defense witnesses would violate not merely English laws but "all lawes, for in perplexitie of Evidence where the [J]udge is to give sentence of life or death our Law taketh away witnesses from the guilty." "perplexitie," as did his contemporaries, to mean a conflict in evidence. His argument therefore amounted to this: Because no system of law can justly impose a sentence of death in the face of conflicting oaths, the defendant must be denied his witnesses.

Other theories could possibly explain the distinctive treatment of the problem of sworn witnesses in capital cases. Although these alternatives to the "legitimacy" theory I have set out have some force, none provides as persuasive an account of the body of rules that governed criminal trials in the early-modern era. The first of these theories took the following expression in the 1607 parliamentary debates just mentioned: "In favor of Life the Law doth presuppose, and not in other Cases, that Men will bee more prone to forswear themselves, and therefore to prevent Perjury, doth not admitt of witnesses . . .,67 That is to say, because witnesses will be tempted to lie to save the defendant's life, we must not permit defense witnesses in death cases. As phrased, this rationale presents merely a slight twist on the theory I have set out above: We must be especially mistrustful of a jury's judgment of credibility in death cases, because witnesses have far greater incentives to lie.

In later years, however, this theory found a somewhat different form. Around the turn of the eighteenth century, Jeffrey Gilbert ${ }^{68}$ put this spin on the problem of the greater incentives to lie in capital cases: ${ }^{69}$

In Cases of Treason or Felony no Witnesses are sworn against the King; and the Reason seems to be because Men think it an Act of

65. As I will set out in more detail below, see infra note 98 , it is possible-though unlikely-that Parliament granted sworn defense witnesses to persons charged with a single narrow felony in 1589.

66. The Parliamentary Diary OF ROBERT BOWYER, 1606-07, at 325 (David Harris Willson ed., 1931) [hereinafter BOWYER]. Another example of a procedural rule that distinguished between capital and noncapital crimes comes from George Mackenzie's late-17th-century treatise on Scoltish law, which held that the privilege against self-incrimination applied only in capital cases:

Neither is the Defender forced to give his Oath [against himself] in Criminals, as he is in civil

Cases.... But because the excessive love which we bear to Life, is the occasion of this exemption; therefore where the punishment is not corporal, ... the Defender will be forced sometimes to give his Oath....

Sir George Mackenzie, The Laws and Customs of Scotland on Matters Criminal 261.62 (Edinburgh, The Heirs and Successors of Andrew Anderson 2d ed. 1699).

67. BOWYER, supra note 66 , at $314 \mathrm{n} .1$ (seprinting a summary of the debate).

68. Michael Macnair reports that contemporary sources use this spelling of Gilbert's first name, though more modern texts use "Geoffrey." See Michael Macnair, Sir Jeffrey Gilbert and His Treatises, I5 J. LEO. HIST. 252, 261 n.l (1994).

69. For more information on Gilbert, his treatise on evidence, and when he wrote it, see infra notes 160-161 and accompanying text. 
Piety to save the Life of a Man, and therefore may stretch a little beyond their Knowledge, and for that Reason are not admitted to hurt their Consciences by Swearing ... . ${ }^{30}$

Gilbert's emphasis here was not on the jury's capacity to detect lies or on the danger that perjury poses to the search for truth, but rather on the solicitude we must show to those who might be tempted to lie: We should not let them "hurt their Consciences by Swearing" a false oath.

It is difficult to know today whether protecting the souls of possible perjurers was a genuine purpose of the rule barring defense witnesses in capital cases or was instead a mere "rationalization and an afterthought." I am for various reasons inclined to think the latter. One reason is that it is hard to reconcile a systemic solicitude for the souls of the defendant's witnesses with the system's apparent unconcern for the defendant's own fate. After all, the system apparently preferred to let innocent defendants die for want of witnesses than to hurt the souls of witnesses who might lie to save the guilty. (I must allow, though, that the authorities may have regarded the damnation of a witness to be a greater evil than a wrongful execution, ${ }^{72}$ and they may have been concerned for their own souls should they tempt witnesses to lie. ${ }^{73}$ ) A second reason to doubt the solicitude rationale is that a theory founded on the system's concern for the souls of perjurers cannot explain other evidence rules, such as Bethel's rule, which sought to erase apparent conflicts of oaths by advising the jury, when possible, to reconcile conflicting testimony. By papering over one witness's lies, Bethel's rule worked to support the apparent legitimacy of verdicts, but it did nothing (if we assume a canny deity) to protect the souls of those who actually lied. A third reason is that the solicitude theory surely cannot explain the common law's failure to punish witness perjury. ${ }^{74}$ This omission would have been altogether out of line with a systemic concern to protect (and deter) witnesses from perjury-but it adds substantial support, as I will argue in Part II, to the legitimacy theory. Still, at bottom, both the solicitude theory and the legitimacy theory can help to explain those rules that dictated which witnesses had access to the oath. To that extent, they must exist side by side.

Another alternative to the legitimacy theory is less subtle: Perhaps the system forbade defense witnesses in capital cases to insure that the Crown, in

70. JeFFrey GiLbert, THE LAW of Evidence I59 (London. Henry Lintot 1756).

71. Alber W. Alschuler, A Peculiar Privilege in Historical Perspective: The Right To Remain Silent. 94 MiCH. L. REV. 2625, 2645 n.77 (1996) (debating how to charactenze the solicitude rationale)

72. I thank Kenji Yoshino for pressing me on this point.

73. A tract writer of Gilbert's day explained the danger of tempung another to lie under oath: "He who exacts an Oath of another, whereby he either certainly knows, or may reasonably suppose, that the Person of whom he requires it will forswear himself .. must expect to render an Account for his Uncharitableness towards his Neighbour's Soul." Willuam WAKE. A Practical Discourse Concerning SWEARING 25-26 (London, Richard Sare 1696) (emphasss omitted).

74. See infra note 106 and accompanying text. 
the most serious of criminal cases, would win. Several historians ${ }^{75}$ and at least a couple of seventeenth-century critics $^{76}$ attributed the rule against defense witnesses in part to a frank desire to favor the prosecution. But why should a King powerful enough to ban opposing witnesses in major cases be so content to see his authority flouted in minor (misdemeanor) cases? Not all of the latter, as we will see when we address Bethel's Case, were unimportant to the King. Indeed, why should such a King have been content to lose so many felony trials? There is fairly good evidence that throughout the history of the English criminal jury trial, a solid proportion of all prosecutions ended in acquittals. ${ }^{77}$ That an all-powerful monarch could have put an end to such lawlessness simply by abolishing trial by jury merely points out how far short the King fell from omnipotence. His justice had to wear a mantle of legitimacy. If the King had the power to ban opposing witnesses in capital cases, it is perhaps because the resulting verdicts, supported by an unopposed and divinely enforced oath, would have a claim to legitimacy greater than any the Crown could grant or take away.

\section{The Reality Beneath the Illusion}

But if the system staked its legitimacy so fully upon the oath, then what need did it have for the jury? What purpose did the jury serve beyond acknowledging the witnesses' oaths and acting upon them? For that matter, why were there so many acquittals in a system that contrived so well to protect the oaths of prosecution witnesses from contradiction? These questions lead us to the third trait that the trial jury shared with the old ordeal: Each institution permitted the system to lay claim to a divine sanction for its verdicts while in reality meting out a very human form of justice.

As for the ordeal, it is nothing new to say that human judgment often tinged its verdicts. After all, someone had to determine when the iron was hot enough and whether the wounds were clean enough or whether a partly

75. See, e.g., 1 STEPHEN, supra note 28 , at 354 ("The true reason for the rule as to restricting the defence is obvious. It increased the power of the prosecution, and saved trouble to those who conducted it."); THAYER, supra note 47, at 157 ("[T]he king, in criminal cases, was no mere ordinary party to an action; the procedure was heavily weighted in his favor."); 2 WIGMORE, supra note $44, \S 575$, at 685 ("No doubt also a general disinclination prevailed to concede anything that would weaken the hands of the prosecution.").

76. See, e.g., John Hawles, Remarks upon the TRYALS 22 (London, Jacob Tonson 1689) ("The reason given that the Indictment is the Suit of the King, and no Councel or Witness is allowable in a capital matter against the King, is foolish ...."); BOWYER, supra note 66, at 311 (quoting a member of the House of Commons at a 1607 debate); see also Trial of Udall, 1 Howell's State Trials 1271, 1281 (1590) ("And the witnesses offering themselves to be heard, were answered, that because their Witness was against the queen's majesty, they could not be heard.").

77. See Green, supra note 64, at 671 ("Throughout the entire mediaeval period for which written records are extant, the great majority of defendants who stood trial were acquitted."). 
submerged body had sunk or floated. ${ }^{78}$ And into any justice system in which human action can distort outcomes, a certain amount of corruption will inevitably seep. Many historians have said as much, ${ }^{99}$ and even a few contemporary complaints have survived. ${ }^{80}$

But while it may be unspectacular to note the potential for manipulation in the administration of the ordeal-we are all familiar with the vagaries of even well-designed justice systems-it is slightly starting to realize that medieval justice systems apparently chose a manipulable system over one that might have been relatively immune from human interference. That is, we can easily imagine an ordeal not so subject to the vagaries of human justice. Given that an omnipotent God surely could have spoken through a throw of the dice, we must assume that the system preferred an ordeal that left room for human discretion. ${ }^{81}$ The institutional brilliance of the ordeal was that it so neally merged the appearance of divine judgment with the reality of a great measure of human control. Its verdicts at once satisfied the public desire that judgments of death be divinely ordained and flattered human notions of substantial justice. In the trial jury, the English justice system managed to reproduce this very useful combination of traits. By forbidding conflicts of oaths in capital cases, the system assured that a jury's verdict of guilt would seem to bear a divine imprimatur. Yet, by granting the jury an unbounded discretion to acquit, the system also assured that the trial process would not devolve into a mechanical totting of oaths, subject to manipulation by those willing to swear a false accusation. ${ }^{82}$

78. See LEA, supra note 18, at 404 (“'TT]he result depended mosily upon those who administered the ordeal."); Peter Brown, Society and the Supernatural: A Medieval Change. 104 DAEDALLS 133, 139 (1975) ("There was a built-in flexibility in the ordeal that enabled the group. 10 mantan a degrec of inituatuve quite contrary to the explicit ideology of the ondeal."): Colman. supra note 20. at 589 (" $A$ somewhat disturbing feature of all forms of ordeal is the lack of quantitative precision in thesr application.")

Margaret Kerr and her colleagues argue that the ordeals "were engineered to ensure a high rate of success." Kerr et al., supra note 19. at 580 . Their evidence shows that men were generally sent to the ordeal of cold water, while women were usually sent to the ordeal of hot iron. The reason. they argue, was that because of higher body fat, "a woman was much less likely than a man to pass the ordeal of cold water." Id. at 582. As for the ordeal of hot iron, they argue that because bum wounds do not tend to become infected before the fifth day after injury. the design of the ordeal. which looked for signs of infection after three days, was tilted toward innocence. See id. at 593.

79. See, e.g., BARTLETT, supra note 17, at 41 ("Having the power to determine, they also had the power to defraud."); Colman, supra note 20, at 589 ("IS]uch inals allowed wide scope for manipulation of all kinds....").

80. See BARTLETT, supra note 17, at 94 (noung that 12th-century popes ordered pnests not to take bribes in the conduct of ordeals); LEA, supra note 18. at 406 (citing a 12th-century Scoltush law forbidding bribery by those administering ordeals); Hyams, supra note 17. at 102-03 \& n.57. $116 \mathrm{n} .140$ (citung contemporary cases).

81. I am grateful to Adam Hirsch for pointing out the significance of nonrandom ordeals

82. Some have argued that medieval and early-modem Contınental justuce systems cmbraced just such a mechanical totting of oaths. See, e.g., John H. LANGBein. ProsectTing CRIME IN THE RENaISSANCE 238 (1974) (noting that under the Roman-canon law of proof of Contunental Europe. the job of the tner of fact "was to apply the rules, to assign arithmetic values to evidence according to the tanff of cogency which the later jurists had worked out"). 
Juries did many things with their unbounded discretion to acquit. Sometimes they protected the accused from government persecution. Sometimes they rejected as unsound a particular provision of the criminal law. Sometimes they bestowed mercy on guilty but worthy defendants. ${ }^{83}$ Sometimes they concluded that the sworn testimony they had heard, even if true, did not add up to a factual case of guilt. And sometimes, no doubt, they rejected the prosecution's sworn witnesses as perjurers-that is, they acted as the system's lie detectors. When they did so, however, they did so privately, without the system's formal invitation and without disturbing the public's perception of a verdict founded on the witnesses' oaths. With an elaborate array of evidentiary devices, the system managed to preserve for a very long time the principle that guilty verdicts in capital cases (and most verdicts in most other cases) should never rest on a merely human choice between two competing versions of a divinely revealed truth. The story that follows traces that principle's long dominance, its slow erosion, and its eventual collapse.

\section{THE RISE OF DEFENSE WITNESSES}

\section{A. Curtains Open: The Sixteenth Century}

Given how thin the evidence has grown with age, we perhaps can do no better than to theorize when speaking about the jury in its earliest years. It would be three centuries after the abolition of the ordeal in 1215 before the workings of criminal jury trials would be revealed with any clarity. A sixteenth-century tract of Sir Thomas Smith ${ }^{84}$ and the accounts of a few high-profile cases of the same era, later bound in Howell's collection of State Trials, ${ }^{85}$ lend some detail where there had been little. Still, it is easy to exaggerate what these sources can tell us about criminal jury trials in the sixteenth century. Smith's description of a sixteenth-century criminal trial, which has served as the basis for self-assured generalizations by modern historians,${ }^{86}$ occupies only a few pages of his treatise. ${ }^{87}$ And the State Trials are an uncertain source in this era. Not for another century or so did verbatim

83. Each of these falls under the general heading of jury nullification. Thomas Green has assembled striking evidence of nullification by medieval juries. He concludes that juries sought to moderate the law of homicide, which as yet made no distinction between murder and manslaughter, by manipulating facts to fit them within the law's narrow notion of proper self-defense. See GREEN, supra note 19, at 28-64. John Langbein reports evidence from a much later era of juries' acting to temper the law's severity, even in the face of clear evidence of guilt. See John H. Langbein, Shaping the Eighteenth-Century Criminal Trial: A View from the Ryder Sources, 50 U. CHI. L. REV. 1, 52-55 (1983).

84. Thomas SMiTh, DE Republica ANGlorum (Mary Dewar ed., Cambridge Univ. Press 1982) (1583). Smith wrote his treatise in the 1560s; it was published in 1583. See SHAPIRO, supra notc 28, at 159-60.

85. I will refer to this collection as Howell's State Trials, as that is the more common designation. Some of the volumes were in fact edited by William Cobbett and bear his name.

86. See, e.g., 1 STEPHEN, supra note 28 , at 346-50.

87. See SMITH, supra note 84 , at 112-15. 
shorthand reporting become a common feature even of celebrated trials. ${ }^{8 s}$ Sixteenth-century trial reports were short, incomplete, and subject to distortion according to the allegiances of the source.

Even allowing for the shortcomings of our sources, we may safely draw three useful conclusions about sixteenth-century criminal procedure. The first is that the defendant could call no witnesses. There seem to be few explicit statements of this negative proposition, but all the major authorities have accepted it as true. ${ }^{89}$ The trial of Nicholas Throckmorton of 1554, contained in the State Trials, supplies the most famous expression of the rule. ${ }^{00}$ Throckmorton attempted to call a witness on his behalf, but the witness "was not suffered to speak." "[W]hy," Throckmorton asked the court, "be ye not so well contented to hear truth for me, as untruth against me?" ${ }^{\text {"92 }}$ He pointed out that Queen Mary herself had instructed the court that "notwithstanding the old error amongst you, which did not admit any witness to speak [against the Queen], ... her highness's pleasure was, that whatsoever could be brought in the favour of the subject, should be admitted to be heard." The chief justice did not respond to Throckmorton's allegation, ${ }^{94}$ but merely told him: "[Y]ou have no cause to complain, for you have been suffered to talk at your pleasure." 95

A trial at which only one side may present evidence will never in the normal course of events call on the jury to choose between sworn witnesses. Yet, as the chief justice told Throckmorton, defendants were "suffered to talk at [their] pleasure." Hence our second bit of information is that defendants themselves could speak at trial, and juries therefore often must have heard competing versions of events. Smith made as much clear in the most famous passage of his treatise:

88. See John H. Langbein. The Criminal Trial Before the Lawvers. 45 U Chil L REv. 263. 264-67 (1978). For a particularly sharp waming to those who would rely on the accounts in Stute Truals. see G KITSON ClaRK, THE CRITICAL HISTORIAN 92-96, 107-15 (1967).

89. See, e.g., 4 WILliam BLACKSTONE. COMmentaries *359. Anthony Musson has recently reported at least scattered instances of defense witnesses speaking at carly-14th-century tnals. See Musson, supra note 23, at 202-03,205. His descriptions do not, however, leave the impression of anything like a regularized practice.

90. See Trial of Throckmorton, 1 Howell's State Trals 869 (1816).

91. Id. at 885 .

92. Id.

93. Id. at 887-88.

94. He said that the Queen had delivered her command not to hum. but to the chicf justice of the Cour of Common Pleas. See id. at 888. Perhaps his meaning was that the Queen had merely authonzed cavl adversaries to call witnesses against her. The origun and general importance of Mary's dispensation are unclear.

95. Id. at 888 . The only other contemporary source I have seen for the proposition that defendants could not call witnesses is the Trial of Udall. I Howell's State Tnals 1271, 1281 (1590) ("And the witnesses offering themselves to be heard, were answered. that because their Witness was aganst the queen's majesty, they could not be heard."). 
The Judge first after [the witnesses] be sworne, asketh first the partie robbed, if he knowe the prisoner, and biddeth him looke upon him: he saith yea, the prisoner sometime saith nay. The [victim says], I knowe thee well ynough, thou robbest me in such a place, thou beatest mee, thou tookest my horse from mee . . . : the theefe will say no, and so they stand a while in altercation ....96

But although the jury indeed faced a conflict in testimony, it was not a sworn conflict. And this is the third bit of information we can draw from these records: While the accuser's allegations were sworn, the defendant's denial was not. ${ }^{97}$

The defendant's inability to take the oath made the jurors' task as lie detectors easier. By choosing simply to credit sworn evidence over unsworn, they could avoid a difficult comparison of credibility. Many small comments in various treatises and trial records, which I will report in time, suggest that juries routinely did just that. Although some juries no doubt chose to credit the defendant's unsworn tale over the prosecution's sworn testimony, the system never put juries in capital cases to the task of weighing competing oaths. And it never put juries in a position where, in order to condemn the defendant, they would have to reject sworn testimony.

It therefore should be no surprise that when the system did begin to permit defendants to call witnesses, it did not permit defense witnesses in felony cases to be sworn. The first defense witnesses probably appeared in the late sixteenth century, not long after Queen Mary reportedly endorsed the change. ${ }^{98}$ By the middle of the next century, unsworn defense witnesses had become a regular fixture of the criminal courts. ${ }^{99}$ In one sense, their presence did little to

96. SMITH, supra note 84 , at 114 .

97. Once again, finding affirmative contemporary evidence for this negative proposition is not easy. Robert Palmer reports that, in the 1290s, "the accused was specifically not to testify under oath." See Palmer, supra note 43, at $795 \mathrm{n} .24$. The rules of pretrial examination developed during Queen Mary's reign neglected to provide that defendants be sworn. See LANGBEIN, supra note 82, at $11,17,25$. It is possible that contemporaries would have understood a defendant's right to give sworn testimony as an imposition, analogous to a coerced confession. See Alschuler, supra note 71, at 2645.

98. A 1589 statute allowed "lawful witness[es]" for those charged with embezzling the Queen's munitions. See An Act Against the Imbezzelling of Armour, Habilaments of War and Victual, 31 Eliz., ch. 4 (1589). Although neither the Act nor Blackstone's treatment of it, see 4 BLACKSTONE, supra note 89, at *359-60, specifies whether these "lawful" witnesses were to be sworn, I think it is likelier they were not. In the Act To Abolish Hostilities with Scotland of 1607, Parliament specifically provided that defendants covered by that Act should have "good and lawfull Witnesses upon their oathes." 4 Jam., ch. $1, \S 16$ (1607). But see 2 MATTHEW HALE, THE HISTORY OF THE PLEAS OF THE CROWN 283 (Philadelphia, Robert H. Small 1847) (saying that the 1589 statute "seems virtually to allow the prisoner's testimony upon oath").

99. See LANGBEIN, supra note 82, at 25 \& n.6; THAYER, supra note 47, at 157, 159 n.4; 2 WIOMORE, supra note $44, \S 575$, at $685 \&$ n. 46 . Both Coke and Hale suggested there was no authority for barring sworn defense witnesses in felony trials. See COKE, supra note 33, at 79 ("[T]here is not so much as scintilla juris against it."); 2 HALE, supra note 98, at 283 ("Regularly the evidence for the prisoner in capital cases is given without oath, tho the reason thereof is not manifest . ..."). Neither author, however, disputed that such a ban was in place. See also Trial of Roswell, 10 Howell's State Trials 147, 267 (1684) (Jeffreys, C.J.) ("I think it is a hard case, that a man should [not have] his witnesses examined upon oath: But yet you know as well as I, that the practice of the law is so; and the practice is the law."). 
enlarge the jury's role as lie detector. In the face of the prosecution's sworn testimony, the jury remained free to disregard these new witnesses' unsworn allegations. ${ }^{100}$ Again, as I will report later, trial records suggest some juries did just that.

James Fitzjames Stephen, one of the few historians to consider this state of affairs in any depth, traced the bar against sworn defense witnesses to Roman-canon law principles, which exalted the primacy of the oath. Because it would have been "'most unformal" under the civil law to confront one oath with another, ${ }^{101}$ the system simply forbade one party's witnesses to take the oath. Stephen went on to quote David Hume (a nephew of the philosopher), who attempted in his Commentaries on the Law of Scotland of 1790 to explain the system's old aversion to conflicting oaths:

"The sort of argument, as far as I can collect it, by which our lawyers justified so strange a restriction of the [defendant's] proof. was to this purpose, that the accuser had set forth certain facts and qualities in his libel, and must establish these with evidence to be used in his prosecution; that if he failed to prove them the [defendant] must be acquitted, of course, for that reason only, though there were no evidence on his part at all; and that, on the other hand, if the prosecutor proved his libel, it could serve to no purpose, but to occasion perjury, to admit a contrary proof on the part of the [defendant], whose witnesses, if they contradicted what had already been proved by those for the prosecution, must be swearing falsely, which it was the business of the Court to deny them an opportunity of doing. ... In short, the notion of a conjunct probation of the libel and defences before the assize was thought too dangerous to be admitted: the prerogative of proving, and the choice of the witnesses, were to be given to one of the parties only; and on the evidence taken by that party the issue was entirely to depend." 102

Lawyers, Hume said, believed that once "the prosecutor proved his libel," then any contrary defense witness "must be swearing falsely." As lawyers of this era often used the word "prove" to mean nothing more than to swear to

100. See 4 BLACKSTONE, supra note 89 , at $* 359-60$.

101. 1 STEPHEN, supra note 28, at 350-51. Siephen was quoung DAINES BARRINGTON. Observations

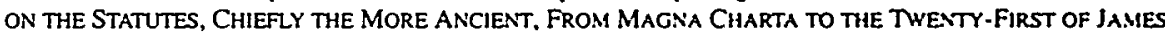
I. CAP. XXVII, at $89-90$ (London. W. Bowyer 1766). Barrington in tum was quotung from a paper read to the House of Commons during the 1607 debates on the Act To Abolish Hostulities with Scolland. see 1 H.C. JOUR. 378-79 (June 4, 1607), which I will take up shortly, see infra Section II.B. There is no particular reason to trust facts stated in the 1607 paper. which has netther a byline nor citations. My purpose now is to try to explain why the common law banned defense witnesses. Contemporary beliefs about civil law rules, however inaccurate, can help in this inquiry.

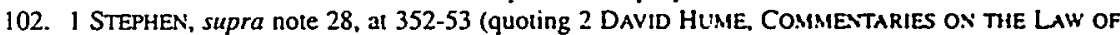
SCOTLAND RESPECTING TRIAL FOR CRIMES 70-72 (Edinburgh. Bell \& Bradfute 1800) (1790)). Hume is writing here about Scottish law in earlier times, but he does nol specify the era. Whether Scoltish law permitted swom defense witnesses was a point of confusion at House of Common debates on the Act To Abolish Hostilities with Scotland in 1607. See infra text accompanyıng notes 126-128 
something, ${ }^{103}$ there was implicit in this belief a presumption that sworn evidence is truthful. At a time when people took the power of the oath seriously, ${ }^{104}$ such a presumption must have sounded less odd than it does today. But to protect that presumption, the system had to avoid the spectacle of competing oaths. ${ }^{105}$

By forbidding defense witnesses to testify under oath, the system permitted itself the luxury of pretending there was no perjury in its midst. And in fact, during the first centuries of the criminal trial jury, it appears there was no crime of witness perjury recognized at common law. ${ }^{106}$ Denying the very

103. See, e.g., GILBERT, supra note 70 , at 156-57.

104. Popular tracts of the late 17 th century, when defense witnesses in felony cases remained unsworn. attest to the awesome power accorded the oath. See, e.g., JOHN ALLEN, OF PERJURY 15 (London, Benjamin Tooke 1682) ("[A]n Oath is ... [t]he greatest assurance, that a Man can give of the truth of his Testimony: the last result, the highest and utmost appeal that we can make; . . . and the best means to find out the truth of Matter of Fact, to determin[e] of Right and Wrong, to give every Man his due, to clear the Innocent, and discover the Guilty ...."); A GUIDE TO ENGLISH JURIES 49-50 (London, Thomas Cockerill 1682) ("[l]f one forswear one's self, one virtually in so doing utterly forsakes God, and his Mercy and Truth. Says a Learned Man, part of the Oath is So help me God, viz. I pray God he will never help me, if I shall not sincerely and faithfully keep this my Oath. . . . Perjury is of its Nature a contempt of God."); PERJURY THE NATIONAL SIN 4 (London, Randall Taylor 1690) ("That many are not struck dead with an Oath in their mouths, or come to some other fearful end, as some do, is a luculent testimony both of God's great patience, and of a Judgment to come . . . .); see also SUSAN STAVES, PLAYERS' SCEPTERS: Fictions OF AUTHORITY IN THE RESTORATION 193 (1979) (arguing that during the Restoration, "the idea that sworn testimony must be believed because it was swom was only very slowly abandoned").

105. Thomas Comber explained the problem of competing oaths in a 1681 assize sermon: "One would imagine nothing could tempt a Rational Man [to perjury] if the too frequent and sad Experience of Opposite, yea of Contradictory Oaths (in this Impious Age of ours) did not convince us, that nothing is too monstrous or unreasonable for an $l l l$ Man to do." THOMAS COMBER, THE NATURE AND USEFULNESS OF SOLEMN JUdicial SWEARING 39 (York, Samuel Roycroft for Robert Clavell 1682), quoted in STAves, supra note 104 , at 231.

106. See Damport v. Sympson, 78 Eng. Rep. 769 (K.B. 1596) ("Until the statute of 3 Hen. 7. c. 1, which gives power to examine and punish perjuries in the Star-Chamber, there was not any punishment for any false oath of any witness at the common law ...."); Onslowe's Case, 7 \& 8 Eliz., Mich., 2 Dyer 242b, 242b (C.P. 1565); 2 POLLOCK \& MAITLAND, supra note 24, at 542-43; 3 STEPHEN, supra notc 28, at 241-48. The only form of perjury known in the early centuries of the criminal trial was the perjury of jurors who retumed a knowingly false verdict, punished by a process known as "attaint." See 3 STEPHEN, supra note 28, at 241-42; Sipek, supra note 48, at 65. Coke's opinion that "perjury of witnesses was severely punished by the ancient laws of the realm," COKE, supra note 33, at 163-64, was, Stephen said, "a good illustration of the unintelligent patchwork way in which [Coke] writes on all subjects," 3 STEPHEN, supra note 28, at 248.

There is some suggestion that witness perjury was punished in ecclesiastical courts, see Damport, 78 Eng. Rep. 769 (K.B. 1596); 2 POLLOCK \& MAITLAND, supra note 24, at 542-43; 3 STEPHEN, supra notc 28 , at $243-44$, but Coke wrote that the ecclesiastical courts had no jurisdiction over "perjury concerning any temporall act," COKE, supra note 33, at 164. Michael Gordon comments that "[i]t is certain that if an ecclesiastical court had attempted to assert jurisdiction over perjury committed in a common-law proceeding, it would have been immediately and all but automatically prohibited." Michael D. Gordon, The Perjury Statute of 1563: A Case History of Confusion, 124 PROC. AM. PHIL. Soc' Y 438, 442 (1980). The Court of Star Chamber, he adds, probably also lacked jurisdiction over witness perjury in common law courts. See id. at 443-44.

Gordon argues that although there was no common law crime of "perjury," false testimony could be punished as "maintenance," usually defined as an officious interference in a suit in which one has no interest. See id. at $445-48$. Gordon says that the argument about whether perjury was a crime is therefore one of mere semantics. See id. Even if Gordon is correct, however, and perjury was punished under the guise of maintenance, the distinction was hardly one of semantics. As I will argue shortly, the system's aversion to "perjury" prosecutions was that they broadcast the failure of the oath to secure truthful testimony. The ruse of "maintenance" prosecutions might not have done that. 
existence of perjury was convenient for the system in two ways. First, and most obviously, it avoided the damage that a perjury prosecution might have caused to the public's confidence in the accuracy of jury verdicts. Even to acknowledge the possibility of perjury would have revealed to the public that the system's main means of ensuring truth did not work. As a sixteenthcentury court reasoned, "[T] he law intends the oath of every man to be true; and therefore .... there was not any punishment for any false oath of any witness at the common law." ${ }^{107}$ By the same token, the system contrived that two oaths should never conflict-a circumstance that would have trumpeted one witness's perjury and the failure of the oath. Second, denying the existence of perjury avoided a dilemma that was inherent in the system's reliance upon the oath as a source of truth: If a felony conviction may not rest on a jury's choice between two oaths, then the system may never condemn a perjurer. For at any perjury trial, the jury would have to choose between the accuser's oath and the defendant's own (allegedly perjured) oath.

That dilemma may explain why, after Parliament finally made perjury a crime in $1563,{ }^{108}$ many and perhaps most perjury prosecutions took place in the Court of Star Chamber. In the Star Chamber, the Continental rule, requiring the oaths of two witnesses to sustain a criminal prosecution, seems to have prevailed. ${ }^{109}$ The two-witness rule ensured that a perjury prosecution would never reduce to a simple and (by hypothesis) unprincipled choice between two oaths - the accuser's versus the defendant's. When the common law courts took over perjury trials after the abolition of the Star Chamber in $1640,{ }^{110}$ they soon imposed a rule that the oath of a single prosecution

107. Damport, 78 Eng. Rep. at 769 (emphasss addcd).

The gradual, grudging development of the cnme of perjury betrays the system's embarrassment at having to admit the phenomenon existed. Parlament recognized the cnme of subomation of perjury in 1540, a full generation before creating the crime of perjury. See Against Mantenance and Embracery Byeng of Titles \&C., 32 Hen. 8, ch. 9. \$3 (1540): Sipek, supra note 48, at 66 Subomation of perjury. at least if not successful, does not so greatly threaten the power of the oath. And even after perjury was made a crime, there seems to have been a rule that a witness's perjury in a capital case would not be prosecuted after verdict and sentence are read. "Iest it should bring a public scandal upon the justuce of the kingdom if the cause of a person so committed should receive new examination." WILLAaM HLDSON, A TREATISE IN THE COURT OF STAR CHAMBER 71-82 (photo. repnnt 1986) (1792). quoted in 3 STEPIEx. supra note 28, at 247; see also Michael D. Gordon. The Invenion of the Common Law Crume Perjun and the Elizabethan Courts, 24 AM. J. LEGAL HIST. 145. $164-66$ (1980) (discussing doubis that persisted after passage of the perjury statute about whether perjury by a crown witness and perjury at a proceeding that was initiated by indictment were punishable).

108. See An Act for Punishment of Such as Shall Procure or Commut Any Wilful Perjun. 5 Eliz . ch 9 (1563).

109. See Gordon, supra note 107, al 159-63: Wigmore. supra note 43, at 107. see also 9 HOLDSWORTH, supra note 43, at 206 (observing disagreement in the cases and suggesting that the two-witness rule was "almost ... accepted" in the Star Chamber but not "invarnable"). Note that the process of attaint, by which a jury was charged with returning a perjured verdict, required a new jury of 24 persons to try the first panel of 12-that is, two new oaths for each old oath. See ForTescte, supra note 52, at 61-63; 1 HOLDSWORTH 3d ed., supra note 43. at $338-39$ (discussing the law in Bracton's time).

110. See Wigmore, supra note 43 , at 107. 
witness was insufficient to convict."' Blackstone's famous justification for the rule-that "one witness is not allowed to convict a man indicted for perjury; because then there is only one oath against another"1:2 -merely repeated what common law judges had been saying for generations. ${ }^{113}$ Even today, in most jurisdictions, a single oath remains insufficient to support a perjury prosecution. ${ }^{114}$

The dilemma of perjury prosecutions also may explain why Parliament did not make perjury a capital offense-it was created a mere misdemeanor and has remained noncapital. ${ }^{115}$ Here we have, I suggest, a consequence of the

111. Wigmore labored without much success to reconcile this bit of English numerology with his insistence that Continental ideas about the oath never took hold on English turf. He argued, first, that by the time the common law courts inherited the prosecution of perjury cases from the Star Chamber in 1640. the need for two witnesses in perjury cases (enforced in the Star Chamber) was too well-established to change. See id. He did not attempt to explain why the two-witness rule did not survive in the case of other offenses traditionally prosecuted in the Court of Star Chamber. He argued, second, that the "real explanation" for the survival of the numerological rule in perjury was probably a simple if delicate matter of timing. Id. At the time the common law took over perjury cases in the early 17th century, Continental notions of the oath were still viable, but the "corrective notion-that of the jury as witnesses-had practically disappeared, and thus the way was open." Id. at 107-08. The difficulty with this latter argument is that the corrective notion of the jury as witnesses, as I have argued above, see supra notes 46.51 and accompanying text, may never have amounted to all Wigmore thought. In the end, Wigmore fell back on the very traditional argument that perjury is different from all other crimes because "if but one witness was offered, there would be merely (as Chief Justice Parker said) oath against oath." Id. at 108. That is, I think, the right answer, but it begs the question of why Wigmore's common law jury should have been unable to resolve the conflict between oaths.

112. 4 BLACKSTONE, supra note 89 , at *358. Blackstone cited similar reasoning to explain the two-witness rule that generally prevailed in treason prosecutions (a rule that survives in Article III, Section 3 of the United States Constitution). Two oaths are needed, he said, perhaps to overcome the defendant's sworn allegiance against the King. See id. But Blackstone then added that "the principal reason" for the rule, "undoubtedly, is to secure the subject from being sacrificed to fictitious conspiracies, which have been engines of profligate and crafty politicians in all ages." Id. Later authorities endorsed this second rationale. See, e.g., W.M. BEST, A TREATISE ON THE PRINCIPLES OF EVIDENCE AND PRACTICE AS to PROOFS IN COURTS OF COMmON LAW $\S 409$, at $* 450-51$ (Philadelphia, T. \& J. W. Johnson 1849); THOMAS PEAKE, A COMPENDIUM OF THE LAW OF EVIDENCE 9-10 (London, Brooke \& Clarke 2d ed. 1804); S.M. PrIILLIPPS, A TREATISE ON THE LAW OF EVIDENCE 107-08 (London, A. Strahan 2d ed. 1815); Wigmore, sipra note 43, at 101 (arguing that legislators felt more vulnerable to prosecutions for treason than for petty crimes). Note that the latter rationale suggests a lack of faith in the jury's lie-detecting powers (why fear false accusations if we trust juries to detect them?), but it does not manifest the fear of conflicting oaths that clearly motivated the rule in perjury.

113. Wigmore cites as follows: $R$. v. Fanshaw, Skinn. 327 (1693) ("There being but the oath of the prosecutor, and so oath against oath, the defendant was acquitted."); R. v. Muscot. Y.B. 10 Mod. 192 (1714) (Parker, C.J.) ("[T]o convict a man of perjury, a probable, a credible witness is not enough; but it must be a strong and clear evidence, and more numerous than the evidence given for the defendant; for else there is only oath against oath."); and R.v. Nunez, Lee cas. t. Hardw. 265 (1736) (Hardwicke, C.J.) ("[One witness is not sufficient] unless there were very strong circumstances; because one man's oath is as good as another's."). See Wigmore, supra note 43, at 106 n.2.

114. See, e.g., AlA. CODE § 13A-10-105 (1975); CAL. PENAL CODE $\S 118$ (b) (West 1988): KY. REv. STAT. ANN. § 523.060 (Michie 1990); TEX. CRIM. P. CODE ANN. \& 28.18 (West 1995).

115. See An Act for Punishment of Such as Shall Procure or Commit Any Wilful Perjury, 5 Eliz., ch. 9, § VI (1563) (establishing a penalty of six months' imprisonment or a fine of £40). James Oldham reports that a 1786 judicial proposal to make perjury capital came to naught. See 2 JAMES OLDHAM, THE MANSFIELd MANUSCRIPTS AND THE GROWTH OF ENGLISH LAW IN THE EIGHTEENTH CENTURY 1066 (1992); see also THE LAW COMM'N, CRIMINAL LAW: OFFENCES RELATING TO INTERFERENCE WITH THE COURSE OF JUSTICE 100 (1979) (noting that the penalty for perjury had remained a maximum of seven years' imprisonment since 1728). 
death-is-different principle presented in Part I. Even when the prosecution could find two sworn witnesses to overcome the defendant's own oath, the system would not put the defendant at risk of life or limb based on a jury's very human judgment that the accusers' oaths - and not the defendant's-were true.

\section{B. The Act To Abolish Hostilities with Scotland}

Our narrative has yet to move past the early seventeenth century, yet already we have seen hints of real change. By allowing even unsworn defense witnesses to take the stand, judges showed a willingness to tolerate at least the appearance of credibility conflicts. And by advising juries, at least occasionally, that they must judge the credibility of both sworn and unsworn witnesses, ${ }^{116}$ some judges signaled a willingness to abandon the cult of the oath. We now move on to explore the system's hesitant embrace of sworn defense witnesses in felony trials.

Our starting point is the 1607 "Act for the utter abolicion of all memory of Hostilitie ... beweene England and Scotland,"117 which set down the form of trial for English subjects who committed crimes in Scotland before fleeing home to England. Although the final form of the Act would deliver a little bit less, the bill as proposed would have given all such defendants the right to call sworn witnesses. Yet the Act To Abolish Hostilities by no means marked a watershed in legal thinking about the power of the oath or about the jury's proper role in settling credibility conflicts at criminal trials. The Act permitted sworn defense witnesses only in the narrow context of cross-border crimes and only in England's three northernmost counties. What is more, the motivation to permit defense witnesses in such cases does not seem to have been any high idea about proper forms of proof, but instead a frank political urge to strike a compromise between English and Scottish trial procedures, combined with a base misunderstanding of the latter.

I emphasize the almost accidental role this Act plays in our story as a counterpoint to Barbara Shapiro's compelling account of the changing nature of proof in the seventeenth century. Shapiro sees the justice system's growing tolerance of credibility disputes in this era as part of a new scientific epistemology that touched not just law, but many other disciplines as well. ${ }^{118}$ The legal system may have grown less averse to conflicting oaths, she says, as lawyers and other thinkers rejected scholasticism's insistence on certainty and grew more comfortable staking action on conclusions drawn from

116. See SHAPIRO, supra note 37, at 185.

117. 4 Jam., ch. $1, \S 1$ (1607).

118. See SHAPIRO, supra note 28, at xiii-xiv, 4-20; SHAPIRO, supra note 37, at 3-6, 9-11. Barbara J. Shapiro, "To a Moral Certainty": Theories of Knowledge and Anglo-American Juries 1600-1850. 38 HASTINGS L.J. 153, 155-58 (1986). 
conflicting evidence. Shapiro calls on the work of Matthew Hale, the leading legal thinker of the time, whose clear endorsement of the jury's role as arbiter of conflicting evidence has a distinctly modern flavor. If the jury has "just cause to disbelieve what a witness swears," Hale wrote, "they are NOT bound to give their verdict according to the . . testimony of THAT witness." Instead, the jury may, "upon reasonable circumstances, including a blemish upon [the witness's] credibility, ... pronounce a verdict CONTRARY to such testimonies." 19

One can quibble about how completely modern Hale's view of jury lie detecting really was, ${ }^{120}$ but there is no question that he stood well ahead of his day. The question is whether his and others' ${ }^{121}$ advanced views on the lie-detecting capacity of juries helped to mold changing practices in the law courts. In this section and the next several, I will argue that they helped but little. The early history of the jury's rise as lie detector was too conflicted and unprincipled to support a theory that links it to a guiding epistemology. It was conflicted, as we will see in Part III, in that long after the system authorized sworn defense witnesses, it continued to endorse rules of evidence that aimed to keep from the jury the sort of credibility conflicts that sworn defense witnesses inevitably produced. And it was unprincipled in that it was, at least in the immediate sense, accidental. Both the Act To Abolish Hostilities with Scotland, which we take up now, and the Treason Act of 1696, which we take up next, expanded the jury's lie-detecting role only incidentally to resolving broader political conflicts. Although it is probably true that the ideas of Hale and others influenced in some degree the shape of change, the immediate impetus for change had more to do with parochial politics than with any advancing epistemology of the sort Shapiro describes. ${ }^{122}$

119. Shapiro, supra note 37, at 184 (quoting MatThew HALE, THE History of THE COMmON LAW OF ENGLAND 164 (Charles Gray ed., 1971) (1713)).

120. Hale retained some affinity for the mechanical power of multiple oaths. In another passage Shapiro quotes, Hale began a discussion about how jurors and others should compare the credibility of competing witnesses by noting that something "reported by many Eyewitnesses hath greater motives of credibility than that which is reported by few." SHAPIRO, supra note 37, at 180 (quoting MATTHEW HALE, The PRIMITIVe ORIgINATION OF MANKIND 129 (London, W. Godbid for W. Shrowsberty 1677)). John Locke, whose work on evaluating witness credibility figures in Shapiro's analysis, also placed "'the number of witnesses" first in a list of useful factors. Shapiro, supra note 118, at 161 (quoting JOHN LOCKE, AN ESSAY CONCERNING HUMAN UNDERSTANDING (London, Eliz. Holt for Thomas Basselt 1690)).

121. Justice Francis North most prominently shared Hale's opinion of the jury's role in deciding witness credibility: "'Hereby it appears there is a great Latitude for a jury, they may say they beleev or doe not beleev in any Case, \& concerning any Witnesses." Michael Macnair, A Fragment on Proof by Francis North, Lord Guilford, 8 SEVENTEENTH CENTURY 143, 143 (1993) (quoting North); see also infra notes 178-179 and accompanying text. The vigorous tract literature of the late 17th century includes other statements of the jury's power to accept or reject sworn witnesses. See, e.g., THE ENGLISH-MANS RIGHT: a Dialogue Between a Barrister at Law, and a Jury-Man 8 (London, Richard Fineway 1680) ("When any matter is swom . . . whether it be true or false in point of Fact, the Jurors are proper Judges."). Some of these tracts, of course, were more prescriptive than descriptive.

122. Shapiro does not claim that Hale's work, or that of other thinkers of his day, had much to do with the passage of these laws. Hale came too late, of course, to have influenced the 1607 Act, and the most significant of his legal writings appeared too late to have influenced the Treason Act. See SHAPIRO, supra 
That the Act To Abolish Hostilities with Scotland did not primarily concern the lie-detecting function of the criminal trial jury is plain from its title. The Act aimed to improve relations between England and Scotland in par by proposing a hybrid of English and Scottish trial procedures for those few cross-border crimes governed by the Act. It is almost as plain that the rationale for permitting sworn witnesses at such trials had mainly to do with the Act's immediate political purposes. Robert Bowyer, whose Parliamentan Diary provides the best legislative history of the Act, ${ }^{123}$ recorded this earliest surviving notation of the reasons to allow sworn witnesses:

[The committee] did resolve that the prisoner who is in such case as afore, to be tried in England for felony etc. alleaged to be doon by him in Scotland shalbe allowed to have witnesses swoorne herd for his purgacion: uppon these reasons, first for that it was affirmed and by Sir Rog[er] Aston saied that the Law of Scotland is so: Next bicause by this lawe wee take from the accused divers advantags which the law of England doth allow in cas of felonies . . . 134

In other words, the committee members had made the roughest of political trades: Because the proposed new form of trial denied defendants advantages typically enjoyed in England but not available in Scotland. ${ }^{125}$ it would grant them the advantage of sworn witnesses, typically enjoyed in Scotland but not available in England. The only difficulty with this bargain, as England's Scottish King informed the House when he objected to the proposal for sworn witnesses, is that Scottish law permitted no such thing. ${ }^{126}$ Although a few members of the House quite guardedly suggested that the King was mistaken, ${ }^{127}$ a paper read to the chamber on the laws of Scotland ${ }^{125}$ suggested that the King was right. Only then, deprived of what was perhaps their main motive for change, did parliamentarians turn to the merits of the proposal to permit sworn defense witnesses.

note 28 , at 58 . Indeed, Shapiro specifically disclaums a causal argument She is tracing. she silys, a sumple concurrence between epistemological progress on the means of gathenng knowledge from witnesses and progress toward freer competition between witnesses in the courtroom. Sre SHAP1Ro. supra note 37. at 193

123. See BOWYER, supra note 66, at 300-30, 350-63 The Journal of the House of Commons has occasional useful information on the Act's passage. See I H C. Jol R $378-89$ (June 4-30. 1607) The Journal of the House of Lords offers far less. The phlosopher Francis Bacon seems to have charred the committee that authored the bill; he reporied the commitice's proceedings to the House of Commons and apparently played a continuing role in managing the bill's passage. See BOWYER, supra note 66 . at 300 . 312, 323-26. Bacon was soon to become solicitor general and, a decade later, was named lord chancellor See 1 Dictionary of National Biography 800. 810.815 (Lesile Siephen \& Sidney Lee eds. Oxford Univ. Press 1963-1964) (1882).

124. BOWYER, supra note 66, at 309 (alterations in onginal) (foolnote omited)

125. See id. at 302-03.

126. See 1 H.C. JOUR. 379 (June 4, 1607): BOwYER, supra note 66 . at 310

127. See BowYER, supra note 66. at $311-12:$ id. at $316 \mathrm{n} !$ ("Rewon giveth us a Cause to thinke. but greatnes of Authority standeth against us."): id at $318 \mathrm{n} 1$ ("As for [the King's] reason at must be like his coin, it must have weight.").

128. See I H.C. JOUR. $378-79$ (June 4. 1607): I STEPHEX, supra note 28, at 351 (quoung the paper) 
In the contest on the merits, the bill's proponents proved to be decidedly less expressive than its detractors. They noted the obvious-that defense witnesses would help innocent defendants. ${ }^{129}$ They made the mandatory argument from biblical authority. ${ }^{130}$ And while they alluded to quite modern notions of proof, they did so in such sketchy terms that we cannot assess the strength of their beliefs. Hence the Act itself tells us that sworn defense witnesses are "for the better discoverie of the Truth, and for the better informacion of the Conscience of the Jurie and Justice," 131 but does not elaborate. Elsewhere we see a quite modern but spare suggestion that the witnesses' "credit [should be] referred to the Jurors." 132 In a very different vein, however, one of the Act's supporters argued that "the life of an Englishman [should not be put] uppon the Oath of a Scott."133 In this offhand remark, we see a possible reason Parliament was content to risk occasional conflicts of oaths in the context of this Act: If an Englishman is tried in England for a crime committed in Scotland, we can expect that his English jury will not be much perplexed by the choice between the oath of his (Scottish) accuser and those of his (English) defenders. Here we have an early case of a phenomenon we will observe later in eighteenth-century courts: The law more readily tolerated credibility conflicts when the jury could readily devalue one party's oath.

In contrast to the bill's rather inexpressive supporters, its detractors set out at least three arguments founded on the system's historic aversion to credibility conflicts and its limited view of the jury's powers as lie detector. Lord Salisbury, in a passage quoted earlier, ${ }^{134}$ articulated the death-is-different position that no justice system may take the defendant's life in the face of conflicting oaths: "[This proposal] varie[s] from our Lawes, nay from all lawes, for in perplexitie of Evidence where the [J]udge is to give sentence of life or death our Law taketh away witnesses from the guilty ...."135 A second opponent advanced the argument, also noted earlier, "that Men will bee

129. See BOWYER, supra note 66 , at 311 ("'[O]therwise an innocent man may be condemned with out defence .... [A]nd seeing the profes against life ought to be more strong and cleere then those for life, I thinke wee ought to allow thes witnesses.") (remarks of Mr. Fuller).

130. See id. at 315 n.l. The reference was vague and uncited: "All Judgement is Gods, and therefore it is fit wee make our Rule of Judgement according to his Law. But his Law doth allow witnesses to the accused." Id.

131. Act To Abolish Hostilities with Scotland, 4 Jam., ch. 1, § 6 (1607). In debate, one member observed that in more important cases "it is more requisite to admitt all means to discover the Truth." BOWYER, supra note 66 , at $314 \mathrm{n} .1$. He added that if civil litigants may have sworn witnesses, then those on trial for their lives certainly should. See id. Another argued that jurors "ought to long to be informed, and to heare all that they can." Id. at 359.

132. BOWYER, supra note 66 , at 309 . We also see a (perhaps anachronistic) suggestion that as jurors "Know the Partys," they are in a position to judge the credit of the witnesses. Id. at $318 \mathrm{n.l}, 326$. But another speaker insisted that the witnesses will "allmost allwaies" be unknown to the jurors. $/ d$. at 353 .

133. Id. at 315 n.1.

134. See supra text accompanying note 66 .

135. BOWYER, supra note 66 , at 325 . 
more prone to forswear themselves" in a capital case. ${ }^{136}$ Lord Salisbury expressed this fear of an epidemic of perjury more colorfully: "[N]o malefacior will stirre foote out of doares to do any villany but he will selt and prepare witnesses for his purgacion and so in shor tyme there will be ready a standinge Crew of damned witnesses." 137 We may presume that by "damned" Salisbury did not intend a mere imprecation, but rather a literal description of the liars' fate. Yet the quoted passage betrays little concern for the liars' souls. Rather, Salisbury's real concern seems to have been the legitimacy of verdicts, for in the next sentence he complained that "there wilbe continuall calumniacion of all verdicts." 138

The detractors' final rationale said a little more about their view of the jury's role as lie detector: "But this Clause that giveth Evidence on both side[s], doth either perplex the Jury, or thereby give them a colourable Excuse whereby they may avoid the Censure of the Starr Chamber." 39 "This speaker foresaw two possibilities. One was that the jurors would be "perplex[ed]" by the conflict in evidence and unable to find the truth. The other was that they would decide wrongly and yet be immune from prosecution (in the Star Chamber) for their own perjury because, however they decided the case, they would have had sworn evidence on their side. ${ }^{1.0}$ Hence the jurors would fail either to see the right or to do the right.

Though more articulate, the opponents of defense witnesses proved to be less persuasive than the proponents, for the proposal became law. Opponents succeeded, however, in winning a critical modification: As finally passed, the Act provided that to avoid "much and frequent perjury," the jurors shall have the discretion "upon their oathes" to hear only those witnesses (whether prosecution or defense) they deemed neither "unfit" nor "unworthy." There are several things to observe about this remarkable provision. The first is that it sought insofar as possible to avoid sworn credibility conflicts. Because the jury would determine without hearing the witnesses ${ }^{142}$ whether they were worthy, those witnesses deemed likely to lie would never take the stand. As one member put it (with reasoning Francis Bacon himself endorsed): "The law of God is that wee admitt no false witnesse and this referring the allowance of witnesses unto the Jury, is the way to avoide false witnesses and

136. Id. at $314 \mathrm{n} .1$; see supra text accompanyıng note 67

137. BOWYER, supra note 66, at 325 .

138. Id. We will see in Par III that Salisbury's propostion that we should not let lihely liars testify is the fundamental strategy of most witness competency rules-a strategy that betrays a lach of confidence that the jury can separate truthtellers from perjurers.

139. BOWYER, supra note 66 , at $317 \mathrm{n} .1$; see also id at $318-19.326$ (quotung speathers making stmular arguments).

140. Another speaker pointed out, however, that jurors are sometimes proseculed for perjun in cival cases in which there is swom evidence on both sides. See $1 d$ at $317 \mathrm{n} 1$

141. 4 Jam., ch. 1, §16 (1607).

142. As one speaker remarked: "[H]eare you will have the Jurors trie the truth of a testumony before they heare it . ..." BOWYER, supra note 66. at 353 (remarhs of Mr Fuller). 
per[j]ury ...."143 This provision worked exactly in the manner of witness competency rules, which kept the most likely liars from testifying.

But it is an extraordinary sort of witness competency rule that gives the jury the discretion to reject untrustworthy witnesses. The Act seems to be of two minds about the capacity of jurors. On the one hand, it gives them the power to reject witnesses altogether. ${ }^{144}$ On the other hand, it presumes that jurors will be unable to reject a lie once a witness has sworn to it. How else can we explain the argument of one speaker that the jury must first decide "whether the witnesse produced be fit to be herd: otherwise a lewde person may be acquited through the testimony of the like person"? ${ }^{145}$ Why should the jury acquit based on the word of a "lewde" defense witness, whom (it is assumed) the jury recognizes as lewd, unless the jury is powerless before the witness's oath? Put differently, a rule that permits a jury to reject unsworn witnesses but that does not trust the jury to reject those same witnesses once they are sworn both exalts the power of the oath and speaks ambivalently about the powers of jurors. Perhaps it is not surprising that, at the insistence of several speakers, ${ }^{146}$ the bill was amended to specify that when exercising their discretion to reject untrustworthy witnesses, the jurors themselves must be on oath. ${ }^{147}$

In the end, the Act To Abolish Hostilities seems to have been born on the cusp of two eras, premodern and modern. Even as it pledged a premodern fealty to the oath, it authorized, apparently for the first time, judicial conflicts of oaths in felony cases. And even as it betrayed ambivalence about the jury's capacity to evaluate witnesses, it gave juries a remarkable power to reject witnesses. Our job now is to track history's course from this juncture forward. If Shapiro is right, and epistemological advances during the course of the seventeenth century broke down old barriers to the idea of juries mediating between competing oaths, then we might expect to see the law welcome sworn defense testimony more broadly.

At first glance, the law seems to have done just that. A half-century after the events just described, during the high radicalism of the Commonwealth, proposals to permit sworn defense witnesses in felony cases were advanced, though they soon died. A half century after that, Parliament finally extended

143. Id. at 360 (remarks of Sir George More). Bacon alluded to the Book of Luke in support of this reasoning: "[T]he greatest truth that eaver was, was interdicted to be testified by an unworthy witnesse for when the Divell would have witnessed of Christ, Thou art the soon of God, he was forbidden by Christ himselfe." Id. at 361 (footnotes omitted). On Bacon's role in managing the bill, see supra note 123.

144. Indeed, the Act requires that jurors in these cases-precisely because they had the power to reject witnesses altogether- "be p[er]sons of better condicion and qualitie" than typical jurors. $4 \mathrm{Jam} .1$, ch. 1 . $\S 16$.

145. BOWYER, supra note 66 , at 309.

146. See id. at 353 (remarks of Mr. Fuller); id. at 355 (remarks of Mr. Yelverton); id. at 362 (remarks of Mr. Hyde).

147. See 1 H.C. JouR. 388-89 (June 30, 1607). 
sworn witnesses to all felony defendants. ${ }^{148}$ Yet these facts support Shapiro's thesis less than at first appears. The surviving tracts of the Commonwealth years tell us little about the impulse behind those earlier, aborted proposals, ${ }^{149}$ but it would not be surprising if the motive was sympathy for the accused, rather than advancing ideas about forms of proof. And as I argue in the next section, the legislation that ultimately granted sworn witnesses to felony defendants appears to have been the product of political conflict, not intellectual growth. The legislators who granted defendants sworn witnesses at the close of the seventeenth century concerned themselves not with the powers of juries to detect lies, but with the simple balance of power in a criminal courtroom.

\section{The Treason Trials and the Treason Act of 1696}

As revolutions in the law go, the Treason Act of $1696^{150}$ passed quietly. In permitting accused traitors to call sworn witnesses, ${ }^{151}$ the Act seemingly abandoned the ancient aversion to conflicts in oaths and marked the beginning of the end of medieval trial procedure. No longer would one side in a criminal case hold a monopoly on the power of the oath. Yet none of those who fashioned the Act seemed to realize the momentousness of the change. Only a few Parliamentarians did more than mention the newly proposed right to call sworn witnesses during debate on the Treason $\mathrm{Act}^{1 \text { 152 }}$ Instead, debate most often centered on demands by the House of Lords for procedural reforms in

148. See I Anne, ch. $9, \S 3$ (1702).

149. See Donald Veall. The Popllar movement for Lall ReirorM 1040-1600. al 154-55 (1970) The tract literature of the Commonwealth penod makes appeals for suom defense witnesses. but in termis so conclusory that it would be pointless to speculate about underlying rationales See, $\mathrm{g}$. Joil Coonk. THE VINDICATION OF THE PROFESSORS \& ProfESSIOV OF TII: LAll 22 (London. Malthew Walbanche 1645), microformed on Thomason Tracts e 320 (17) (Unw Mitcrofilms Int "I) ("I concewe there ure many defects in our Law, both in matters Cnminall on the Crown side and Cisil As that winesses should not be examined upon oath for the pnsoner as well as for the King . "). SEVERAL. RESPECTABLL: Pr.RSO SS OF THE CITY OF LONDON, WESTMINSTER. SOLTHWARK. HaMblets. AND PLACES ADJACENT. THE FUNDAMENTAL LAWES AND LIBERTIES OF ENGLAND 3-4 (n.p.. 1653). microformed on Thomason Tracls e 705 (5) (Univ. Microfilms Int'l) (holding it to be "Our and our Children["]s Right That upon all Tryals Witnesses on both sides may be swom"): WILLAN SHEPPARD. EMGLA.NDS BAL.ME 197 (London. J. Cottrel 1656), microformed on Thomason Tracts e 1675 (2) (Uny Microfilms Int'ls ("That a man in question for his life, may not have Counsel to plead for hım. nor witness to cleer hum. seems hard ")

150. $7 \& 8$ Will. 3 , ch. 3 .

151. As the Act stated:

[A]ll and every Person and Persons whatsoever that shall be aceused and indicled for High Treason ... or for Misprision of such Treason... shall bee received and admutted 10 make any Proof that hee or they can produce by lawfull Witnesse or Witnessese who shall then bee Id. upon Oath for his or their just Defence...

152. The most extensive commentary on the issue consumed barely imo sentences Ser 10 AVCurthill GREY's DEBATES OF THE HOLSE OF COMMONS 289 (London. T Bechel \& PA De Hundl 1769) [hereinafter GREY's DEBATES] (remarks of Sir Thomas Clarges) $("|A| s$ the Law stands now. Wilnesses for the Prisoners are on their Words, and not their Oaths. this Bill is. that the) should not extralagantly say what they will. I think this Bill therefore is for the King's safely") 
the trials of peers. ${ }^{153}$ And if Parliament engaged in any debate at all when it decided six years later to extend the Treason Act's grant of sworn witnesses to all accused felons, ${ }^{154}$ nothing survives of it. ${ }^{155}$ Even modern historians have all but ignored the significance of these two acts in shaping the nature of credibility conflicts in modern criminal trials. Our major evidence treatises allot the Treason Act only passing reference. ${ }^{156}$ And although three scholars have chronicled the Act's passage in some detail ${ }^{157}$-and have duly hailed the Act's grant of counsel to those accused of treason ${ }^{158}$-none has stopped to consider the provision of the Act that concerns us now. ${ }^{159}$

Yet if the historical record documenting Parliament's decision to permit sworn credibility conflicts at major criminal trials is spare, that record is nonetheless strikingly clear. In his early-eighteenth-century evidence treatise, Sir Jeffrey Gilbert set out a simple, half-sentence explanation for Parliament's decision to allow accused traitors to call sworn witnesses:

By the now Law in Cases of Treason the Witnesses against the King are admitted to their Oaths, because this [common law] Rule [against sworn defense witnesses] was abused in the late Reigns to derive a Credibility on the King's Witnesses as being upon Oath, tho' contradicted by Men of better Credit upon their Words only. ${ }^{160}$

153. See infra note 200.

154. See 1 Anne, ch. $9, \S 3$ (1702). The statute read:

[A]ll and every person and persons, who shall be produced or appear as witness or witnesses on the behalf of the prisoner, upon any trial for treason or felony, before he or she be admitted to depose, or give any manner of evidence, shall first take an oath to depose the truth, the whole truth, and nothing but the truth, in such manner, as the witnesses for the Queen are by law obliged to do; and if convicted of any wilful perjury in such evidence, shall suffer all the punishments, penalties, forfeitures, and disabilities, which by any of the laws and statutes of this Id. realm are and may be inflicted upon persons convicted of wilful perjury.

155. Given that the relevant passage of that legislation lies sandwiched between wholly unrelated issues, one can suppose that Parliament gave the matter of sworn defense witnesses little thought. On the other hand, the silence of the historical record may have been the product of accidents of historiography. What we know of the debates surrounding the 1696 Act comes mainly from (wo sources: GREY's DEBATES, supra note 152; and THE PaRliamentaRY Diary OF NARCiSSUS LUTTRELL (Henry Horwitz ed.. 1972) (1691-1693) [hereinafter LUTTRELL]. Neither source extends past the turn of the century.

156. A small footnote in Wigmore's enormous treatise refers to Thayer's "detailed history" of the old rule against defense witnesses and to Stephen's "shorter account." 2 WiGMORE, supra note 44, $\$ 575$, at 685-86 n.48. The former, "detailed" version devotes one sentence to the Treason Act. See THAYER, supra note 47 , at 161 n.4.

157. See James R. Phifer, Law, Politics, and Violence: The Treason Trials Act of 1696, 12 ALBION 235 (1980); Samuel Rezneck, The Statute of 1696: A Pioneer Measure in the Reform of Judicial Procedure in England, 2 J. MOD. HIST. 5 (1930); Alexander Shapiro, Political Theory and the Growth of Defensive Safeguards in Criminal Procedure: The Origins of the Treason Trials Act of 1696, 11 LAW \& HIST. REv. 215 (1993).

158. See, e.g., Rezneck, supra note 157, at 23 ("Without a doubt the most important feature of the new procedure was the clause permitting counsel to make full defense for the accused."); Shapiro, supra note 157 , at 217 (identifying the counsel clause as his "central focus").

159. See Phifer, supra note 157, at 244 (making a glancing reference to the provision for sworn witnesses); Shapiro, supra note 157, at 217 (same); Rezneck, supra note 157, at 22 n.64 (omitting from a "systematic summary of the contents of the statute" any mention of the provision for sworn witnesses).

160. GILBERT, supra note 70 , at 159 . 
That is, Gilbert said, Parliament allowed accused traitors to call sworn witnesses because, in the rash of treason trials that marked the reigns of the late Stuarts, the government so shamefully had employed sworn perjurers to defeat the unsworn but truthful witnesses of the unhappy defendants. Gilberts authority on this point is excellent-he was the most influential evidence scholar of his era. Moreover, he had lived through the debates on the Treason Act and almost surely wrote the words quoted above within a few years of the Act's passage. ${ }^{161}$

I have found no other contemporary commentary that so clearly declares Parliament's motive in granting the right to call sworn witnesses in the 1696 Act. Yet even in the absence of Gilbert's weighty judgment, we could have deduced the same conclusion from the Act's legislative history and historical context. That the bill was first introduced in 1689 is our first clue to its connection with the political troubles that marked the end of the Stuarts' reigns. The Glorious Revolution of the year before had toppled the House of Stuart and installed the rigorously Protestant William III in place of the Catholic James II. ${ }^{162}$ When Parliament met in 1689 , it launched a series of legal reforms designed to keep the King from ever again converting the machinery of justice to political purposes. Parliament granted the King's justices secure salaries and life tenure in good behavior ${ }^{163}$ and reformed the law of treason.

161. Gilber lived from 1674 to 1726. Michael Macnair has argued that Gilbert's treatuse. which did not appear until 1754, was probably written in the carly 1700s. Maenasr has examined the onginal manuscript sources of the treatise and reports that they contan no case citations later than 1710 . See Macnair, supra note 68, at 252, 254, 259, 266-67 n. 107.

I think it is likely that Gilbert wrote the sentence quoted above before 1702 Indeed. It appears he wrote some of his treatise even before passage of the 1696 Treason Act. The paragraph that precedes the sentence quoted above begins, "In Cases of Treason or Felony no Wilnesses are swom against the King . . . GILBERT, supra note 70, at 159. That, of course, ceased to be the law in 1696 Only in the next paragraph-the one quoted in my text-does Gilber acknowledge the change in the law. That maternal seems to have been added during the six-year interval that separated the 1696 Treason Act from the 1702 Act giving all felony defendants the right to call swom witnesses. The use of the word "now" in the opening phrase-"By the now Law in Cases of Treason"-suggests that the paragraph was wntten when the Treason Act was still fresh. And Gilbert's omission of any textual reference to the 1702 Act where such reference would have been natural suggests that the $1702 \mathrm{Act}$ was sull in the future. True, the marginal notation alongside the material I have quoted in my text is to the $1702 \mathrm{Act}$ onls. But it is unlikely that Gilbert made this notation. As Macnair's work makes clear, later edıtors were responsible for many of the citations. See Macnair, supra note 68, at 266 n. 107. In fact. Macnaur reports that a manusenpt of this work held at Harvard Law School bears a marginal notation only to the 1696 Act. But as "Gılbert was a farly sloppy writer," Macnair says, "he may have just missed the Act of 1702." Lelter from Mlıchael Macnasr. Professor, Lancaster University (July 1, 1997) (on file with author).

162. See JOHN KENYON, THE POPISH PLOT 15-16 (1972) (discussing James's religion)

163. Both houses of Parliament passed such a measure in 1692 although it was then vetoed by the Crown. It did not become law until the Act of Settlement of 1701. See An Act for the Further Lumitation of the Crown and Better Securing the Rights and Liberties of the Subject, 1701. 12 \& 13 Will. 3, ch. 2. § 3; SHAPIRO, supra note 37, at 314 n.132; Joseph H. Smith. An Independens Judician: The Colonial Background, 124 U. PA. L. REv. 1104, $1109-10$ (1976). The Act provided that the judges could be removed "upon the Address of both Houses of Parliament." 12 \& 13 Will. 3. ch. $2 . \$ 3$ Although the grant of secure tenure did not take effect until the death of Queen Anne in 1714. she granted all judicial commissions in her reign with tenure during good behavior. See Smith. supra. at 1110 
In the last decade of the Stuarts' reigns, both sides in the political struggle had made rich use of treason charges as weaponry, and both sides had suffered serious losses. The quickest glance at any collection of Howell's State Trials, which reported treason cases among others, attests to the proliferation of treason trials in these years. Whereas the significant state trials of the seventeen-year stretch that ended in 1678 occupy but a single volume of State Trials, and the trials of the seven-year stretch that began in 1689 occupy another single volume, the state trials of the intervening decade fill five full books. Accused traitors had not been the only criminal defendants to lose their lives for want of counsel or sworn witnesses. Yet treason trials had peculiar power to spur reform because of the status of those charged. As Stephen said, "What the political trials of the seventeenth century really did was to expose men of high rank and conspicuous position to the calamities which must have been felt by thousands of obscure criminals without attracting even a passing notice." 164 And indeed, the Parliamentarians who met in 1689 made repeated reference to Algernon Sydney and William Lord Russell-two men of power who had suffered traitors' deaths when James II took revenge on those who had orchestrated the trials and executions of several of the King's adherents. ${ }^{165}$ Little wonder, then, that members of the House of Commons who supported the Treason Act declared " $[t]$ hat their design, in passing this Bill, was, to prevent those abuses in Tryals for Treason . . . for the future; by means of which, during the violence of late Reigns, they had observed divers had lost their Lives." 166

Among those abuses, as Gilbert made clear, was the brazen perjury perpetrated by government witnesses against accused traitors who could not call sworn witnesses in their defense. Stephen said of the Stuart treason trials that the system bestowed on the government's sworn witnesses a presumption of truthfulness that did nothing so much as to encourage them in their lies. ${ }^{167}$

164. I STEPHEN, supra note 28 , at 402 ; see also Wigmore, supra note 43 , at 101 (stating, with respect to an earlier change in treason laws, that "the dominant legislator class, who might not have cared how many a humble subject was unfairly convicted of petty thievery, were well alive to the possibilitics of treason law ... and they probably were moved by the thought of self-protection against the future").

165. See Phifer, supra note 157 , at 240.

166. Charles Montagu reported to the House of Commons that he had used these words during a conference with the Lords to describe the views of Commons. See 10 GREY's DEBATES, supra note 152 , at 229; see also id. at 173 ("This Bill was ushered in by reason of the hardship in the late times, in Tryals for Treason ....") (remarks of Attorney General Treby); LUTTRELL, supra note 155, at 237 ("I cannot but take notice though some gentlemen are now against this bill, yet they complained much of the misconstruction that was made in the last reign in cases of trials in treason. It is what you took notice of when you presented the crown to Their Majesties and made it one of the heads of grievances against the late King.") (remarks of Robert Harley).

167. See 1 STEPHEN, supra note 28 , at $369,398-416$. John Kenyon quotes a striking example of liars cloaked in the presumption of truth. At one Popish Plot treason trial, a judge commented on the unsound testimony of two accusers: "There is some evidence that makes it a very improbable thing to be true what Mr. Bolron has said; and yet Mr. Bolron having said it so positively, and Mowbray agreeing to it, probabilities must give way to positive proofs." KENYON, supra note 162, at 197 (quoting from the trial of Sir Thomas Gascoigne). 
And the most notorious liar of all was Titus Oates, ${ }^{168}$ whose fame as a trial witness eclipsed all others in the centuries before Court TV. Oates's notorious perjury perhaps did more than anything else to move Parliament to grant treason defendants the protection of sworn witnesses. That is in part because Oates was the most prolific of treason trial witnesses. With fourteen executions in his wake, his ultimate conviction of perjury must have caused consternation in many quarters. And it is in part because the fortunes of Oates's adherents and detractors rose and fell with his own. As Wigmore wrote of a different time period, legislators were keenly aware of the dangers of treason law "if the rapid turn of the political wheel should chance to bring them underneath."169 The story of Oates, as we will see, makes plain why those on both sides of the political spectrum stood in fear of the next turn of the political wheel, and it may explain why there was so little need for Parliament to debate that part of the Treason Act that gave defendants sworn witnesses. Moreover, the story of Oates gives us the excuse to explore how the rules constraining who could take an oath, which until now we have studied in the abstract, played out in practice.

Oates made a national sensation when he came forward in 1678 with his account of what soon became known as the Popish Plot. A Jesuit community, he said, had recruited him to join in their scheme to kill King Charles II. Although this unlikely tale of ingenuous Jesuits trusting Oates in their treachery never made much sense, it found a credulous antipapist public. Parliament heard Oates testify and hailed him a hero. ${ }^{170}$ Opposition Whigs saw in him the means to eliminate hated enemies from the King's supposedly Catholic coterie and even to bar the King's Catholic brother. James, from the throne. ${ }^{171}$

At a series of Popish Plot trials that began in the late 1670s, Oates repeated his story for successive juries. As a prosecution witness, he testified with the imprimatur of the oath. The defendants sought to rebut his claims by calling a great number of Jesuits to say that Oates had been with them at a community in France throughout the spring of 1678 and therefore could not have been in London watching them plot the King's death. As defense witnesses, these Jesuits spoke without oaths, and in the main, their words fell feckless against Oates's sworn testimony. It is true that, at one such trial. Justice Scroggs advised the jury to ignore this distinction between sworn and unsworn testimony and to weigh the testimony "according to the credibility of the person and of the matter." 172 But at another, Scroggs responded to a

168. On Oates, see Jane Lane. Titus OAtes (1949).

169. Wigmore, supra note 43 , at 101 .

170. See KENYON, supra note 162. at 81.

171. See John MiLler, POPERY AND POLTTICS IN ENGLANd 1660-1688. al 169.82 (1973)

172. KENYON, supra note 162, at 161 (quoting the Tnal of Whibread. Fenwick. Gavan. Harcount and Turner). 
defendant's protest of innocence with a peremptory, " $[\mathrm{H}]$ ere is one hath sworn it." 173 The defendant's plaintive reply, "It is only Oates, my lord,"174 did not avail him, for he, like thirteen others, went to his death on Oates's oath. ${ }^{175}$

The tables began to turn on Oates and his Protestant Whig sponsors early in the next decade, when Charles II launched a counter-prosecution against those suspected of taking part in a supposed Protestant Plot. ${ }^{176}$ In 1681 , at one of the most famous of these revenge trials, Stephen Colledge faced a charge of having schemed to kidnap and kill the King. ${ }^{177}$ Justice Francis North assured Colledge that the government's monopoly on sworn testimony would not conclude the case against him. "Your witnesses are not upon their oaths," he said, "but they may be witnesses, and their weight is to be left with the Jury . . ."178 Such a modern attitude toward credibility comparisons was characteristic of North, whom Barbara Shapiro has held up as an example of the newly enlightened seventeenth-century attitude toward credibility comparisons. ${ }^{179}$

As the Colledge trial ground to its late-night conclusion, however, enlightenment faded and North reverted to the old-time primacy of the oath. The occasion for this change of heart was the testimony of Titus Oates, on whom Colledge's defense relied, but whose word now had lost the potency of the oath. "I hope my [unsworn] word," Oates told the court, "will be believed as soon as [the government witnesses'] oaths." 180 But when Oates dared contradict a government witness named Dugdale, the King's serjeant, George

173. KENYON, supra note 162, at 194 (quoting from the Trial of Corker). To his credit, Scroggs was not always so sanguine about Oates's credibility. At the trial of Wakeman, he commented that "Mr. Oates stands with the jury, how far they will believe him." Id. at 172. At the trial of the Earl of Castlemaine, he advised the jury, "You must weigh well with yourselves how probable or not probable what [Oates] does swear is." Id. at 200. At the trial of Coleman, however, Justice Jones told the jury: "You must find the prisoner guilty, or bring in [Oates and the government's other witness] perjured." Trial of Edward Coleman, 7 Howell's State Trials 1, 70 (1678), quoted in KENYON, supra note 162, at 125.

174. KENYON, supra note 162, at 194 (quoting from the Trial of Corker).

175. See 1 STEPHEN, supra note 28, at 392 (putting the toll from Oates's testimony at "no less than fourteen innocent lives").

176. See MiLLER, supra note 171, at 189; Shapiro, stupra note 157, at 219.

177. See Trial of Stephen Colledge, 8 Howell's State Trials 549, 549-50 (1681).

178. Id. at 642. Earlier, North had admonished the first defense witness: "Look you here friend, you are not to be swom; but when you speak in a court of justice, you must speak as in the presence of God, and only speak what is true." Id. at 626 . North also qualified his references to the government's testimony with a cautious "[i]f the witnesses say true." E.g., id. at 619. Justice Jones also used a cautionary "if the witnesses are to be believed." Id. at 621 .

179. See SHAPIRO, supra note 37 , at 15, 185-86. Shapiro highlights in particular these words of North:

[I]t is the proper business of . . juries to try not the grammatical construction of words . . . but

the credibility of persons and things; . . . and God forbid that the worst Villains should have

it in their power, by positive swearing, to take away a man's life or estate ... if you believe the witnesses find [the defendant guilty], else not.

FRANCIS ROGER NORTH, THE LIVES OF THE NORTHS 203-04 (A. Jessop ed., London, G. Bell \& Sons 1890), quoted in SHAPIRO, supra note 37, at 186.

180. The Trial of Stephen Colledge, 8 Howell's State Trials at 642. 
Jeffreys, dismissed him: "Here is Dugdale's oath against Dr. Oates's saying." ${ }^{181}$ Turning to North, Colledge attacked the proposition that the government's testimony "must needs be taken for truth" merely because it is sworn. ${ }^{182}$ Surely, he said, Oates's word "is not to stand for nothing, nor to be hooted out of court, because Mr. Dugdale denies it upon his oath." ${ }^{183}$ The prosecutor, however, left the jurors in no doubt about how to balance sworn testimony against unsworn:

[G]entlemen, . . . it is strange to me, that ever you . . . should perjure three men, who positively upon their oaths deny [what] Mr. Oates speaks of against them, I do put that upon your consciences whether you, upon the bare affirmation of Mr. Oates, in this place, will convict three men . . . . I say, whether you will do it upon the bare affirmation of Mr. Oates, against their oaths. ${ }^{184}$

North added to the prosecutor's reasoning his judicial imprimatur, reminding the jury that "here are three men's oaths against one man's affirmation." 135

Four years after Colledge went to his traitor's death, Oates appeared in yet another guise-this time as a defendant charged with perjury. In 1685 the newly crowned Catholic King James II charged that Oates had fabricated the whole of the Popish Plot and had sent fourteen alleged plotters to wrongful deaths. Oates now found how far he had fallen. The same Jesuit witnesses whose unsworn word had been powerless against his sworn accusations at the original Popish Plot trials now took the stand against him under oath. They repeated their charge that Oates had been with them in France through the entire spring of 1678 , when he claimed to have watched the plot hatch in London. And George Jeffreys, whose power had risen as Oates's had fallen and who now presided at his trial, spoke of Oates with utter contempt. He sent

181. Id. at 641 .

182. Id. at 642 .

183. Id. North at first reassured Colledge somewhat equivocally. He sand that the jury "will consider how improbable it is" that three government witnesses would have lied under oath. as Oales clatmed. "and so there are all these three men's oaths against one man's affirmation: but "l musi be left to the jury." Id. at 642. A similar exchange followed shortly thereafter:

Coll[edge]: What is said upon an honest man's word in the face of a court, is certanly to be believed as well as what is swom.

[North]: 'Tis a testimony, that is most certain, and must be left to the Jury. they must Id. at 643 . weigh one against the other.

184. Id. at 706. A similar dynamic prevailed at other trials in which Oates testified without effect for the defense. See, e.g., Trial of Edward Fizharris, 8 Howell's Stale Trials 243, 387 (168I) (reportung the judge's observation, in a charge to jury, that Oates's unswom evidence was "no anster" to another's azh).

185. Trial of Stephen Colledge, 8 Howell's State Trials, at 713 . Though weaker than the government witnesses' oaths, Oates's bare affirmation had at least some force as evidence. In contrast. Colledge's own unswom denials of guilt had, according to North, no force at all. See id. at 625. 681. 712 ; infra note 411 and accompanying text. Although the Treason Act of 1696 granted accused traitors swom wilnesses. nearly 170 years would pass before defendants themselves could testify under oath. See infra Section IV.B. 
the jurors to their deliberations with the thought that "there does not remain the least doubt, but that Oates is the blackest and most perjured villain that ever appeared upon the face of the earth."186

Although Oates was convicted, ${ }^{187}$ Jeffreys and his colleagues were unable to pronounce the sentence they felt he deserved. The "defective" law of perjury, a mere misdemeanor, barred them from hanging Oates, ${ }^{188}$ so they imposed instead a horrific course of whippings, perpetual imprisonment, and regular exposures in the pillory. ${ }^{189}$ Four years later, just as Parliament set out to reform the law of treason, Oates came before the House of Lords to plead for a relief from judgment. ${ }^{190}$ In one sense his petition was a mere formality. With James in flight and a Protestant King about to take the throne, Oates had been released from prison in December 1688-and Jeffreys now stewed in the Tower awaiting trial. ${ }^{191}$ The House of Lords upheld Oates's judgment, but asked the King to pardon him. ${ }^{192}$ Meanwhile, Oates found much vocal support in the lower house. ${ }^{193}$ Commons voted to add a clause to the Bill of Rights to forbid cruel and unusual punishment, ${ }^{194}$ to declare that Oates's sentence was itself "cruel and illegal," 195 and to affirm its continuing belief in the Popish Plot. ${ }^{196}$

To be sure, Commons was not of one mind about Oates. While some members supported a proposal to relieve Oates from his sentence, "some Gentlemen hissed." 197 And in 1692 and 1693, Commons took steps-never realized-to make perjury punishable by death. ${ }^{198}$ But it is precisely this ambivalence toward Oates that makes it seem so likely that Parliament had him in mind when it included in the Treason Act a provision to permit sworn

186. Trial of Titus Oates, 10 Howeil's State Trials 1079, 1226 (1685).

187. See id. at 1227; Trial of Titus Oates (Titus Oates II), 10 Howell's State Trials 1309 (1685).

188. Titus Oates $I I, 10$ Howell's State Trials at 1315.

189. See id. at 1316-17.

190. See TItus OATES, To THE RIGHT HoNourable the LORDS SPIRITUAL AND TEMPORAL AND to THE HONOURABLE THE KNIGHTS, CITIZENS, AND BURGESSES IN THIS PRESENT PARLIAMENT ASSEMBLED; The Humble Petition of TtTuS OATES, D.D. (London, J.D. 1689); see also KenYon, supra note 162. at 259.

191. See KenYon, supra note 162 , at 259.

192. See id. at 260.

193. See 9 GREY'S DEBATES, supra note 152, at 286-94.

194. See KENYON, supra note 162 , at 261 . The addition of a clause forbidding cruel and unusual punishment was a response not merely to Oates's fate, but also to that of a clergyman named Samuel Johnson, convicted of publishing a seditious pamphlet in 1689. See id. at 261 n.*.

195. 9 GREY's DEBATES, supra note 152, at 294.

196. See KENYON, supra note 162 , at 260.

197. 9 GREY'S DEBATES, supra note 152 , at 286.

198. See $10 \mathrm{id}$. at 249 \& n.t; LUTTRELL, supra note 155, at 293. One tract, which complained punningly of the "extream mischiefs . . . lately brought by false OAThES," argued that perjury that leads to the execution of an innocent is murder, and asked why "he whose hands have been unfortunately stain'd in a single Murther, be justly Sentenced to a Halter, while he whose Tongue is Red in the blood of Innocents, has the use of it still." THE THIRD COMMANDMENT 15-17, 20 (London, Joseph Hindmarsh 1685). 
defense witnesses. Both Oates's adherents and his detractors had felt the injustice of the old rule barring sworn defense witnesses. A quiet consensus of support for the proposed right to call sworn witnesses perhaps coalesced around the living memory of Oates. Such a consensus would explain why the proposal to grant accused traitors sworn witnesses, which had been part of the bill since its introduction in $1689,{ }^{199}$ attracted virtually no negative commentary. True, an occasional voice denounced the bill for making treason prosecutions more difficult. Most opposition, however, focused on the bill's initial failure to modify trials of Lords in ways the upper house had long desired. ${ }^{200}$ That issue managed to delay final passage for seven years. Not until the Lancashire Plot trial of 1694 reminded the lawmakers of what they had to fear from spurious accusations of treason did they find the needed momentum to pass the Act. ${ }^{201}$

But whether Parliament was thinking of Oates in particular or of the spectacle of perjured Crown witnesses in general, there is no reason to question Gilbert's judgment that Parliament jettisoned the old rule against sworn defense witnesses because it "was abused in the late Reigns to derive a Credibility on the King's Witnesses as being upon Oath, tho' contradicted by Men of better Credit upon their Words only." ${ }^{202}$ I have seen no evidence either in Parliamentary debate or in contemporary commentary to suggest that lawmakers had achieved a more expansive view of the capacity of juries to resolve sworn credibility conflicts. It is true that an evolving epistemology of the sort Barbara Shapiro describes, which could deal more comfortably with conflicting evidence in the courtroom, might have given the Parliamentarians courage in the change they undertook. It is also true that the Act To Abolish Hostilities and the aborted proposals to permit sworn witnesses made during the Commonwealth years might have been straws in the wind foretelling change. Still, we may conclude this much with confidence: But for the religious strife and consequent spate of treason trials of the late Stuart reigns, and but for the sufferings that notorious perjurers such as Oates inflicted on eminent men of both political persuasions, Parliament would not have granted criminal defendants the right to call sworn witnesses at the end of the

199. See Phifer, supra note 157 , at 244-45.

200. The Lords wanted to limit the King's power to dictate membership on the Lord High Steward's Cour, which sat in judgment at the trials of peers. See 9 GREY's DEBATES. supra note 152. at 172-76: 10 id. at 214, 217-24, 227-40; LUTTRELL, supra note 155, at 74-75. 99-100. 126-29: Phifer, supra note 157. at 250-51. The peers eventually had their way. See An Act for Regulaung of Tryals in Cases of Treason and Misprision of Treason, $7 \& 8$ Will. 3, ch. 3. $\S \mathrm{XI}$ (1696) (providing that all the peers of Partament may take part in the trial of another).

201. See Phifer, supra note 157, at 252-54. Commenting on the tnal. Willian Hayhurst complanned in a December 7, 1694, letter to Roger Kenyon, a member of Parlament, that the goverment's walling witnesses "wwill seldom fail to help a lame dog over stile." Shapıro, supra note 157. al 248 (quotıng Hayhurst's letter).

202. GILBERT, supra note 70 , at 159 . 
seventeenth century or, very likely, for decades to come. ${ }^{203}$ What appears at first to be a defining moment in the history of legal thought, then, turns out to be little more than historical shrapnel, thrown off by the familiar clashes of men of high office.

\section{COPING WITH CREDIBILITY CONFLICTS}

If we look past this story of political intrigue and examine the machinery of the courts, we find other evidence that Parliament's decision to give defendants sworn witnesses had little to do with a new-found faith in the jury's powers of lie detection. A set of long-evolving rules of evidence helped to ensure that, even after sworn defense witnesses began taking the stand, juries often were spared the task of choosing between conflicting oaths. Various witness competency rules operated directly to keep likely perjurers from testifying. And the rule of Bethel's Case encouraged jurors who heard apparently conflicting testimony to reconcile the witnesses' oaths so as to avoid calling either of them a liar. Occasionally, however, despite the protective screen of these rules, two sworn witnesses with conflicting and irreconcilable accounts of events came face to face with a jury. When that happened, the system still did not toss the problem of lie detection into the jury's lap. Instead, it prescribed principles by which the jury was to distinguish truthteller from liar.

I will begin our examination of this evidentiary web with a short survey of competency rules and a more extended exploration of Bethel's rule. After a brief empirical interlude to consider whether these mechanisms succeeded in protecting the oath's apparent power to assure truth, I will take up those rules that applied when credibility conflicts were unavoidable.

\section{A. Witness Competency Rules and the Rule of Bethel's Case}

In the 100 or 150 years before Parliament gave defendants the right to call sworn witnesses, several broad competency rules had evolved to control who could and who could not give sworn evidence in civil and criminal courts. These rules barred from the witness stand all parties to the proceeding - both plaintiff and defendant in a civil suit and all criminal defendants. The rules excluded spouses of parties, persons with financial interest in the case, convicted felons, irreligious persons, and various other classes of people. In effect, this panoply of competency rules preempted the jury's lie-detecting

203. As Phifer has written, "The origins of the 1696 act are not found in the slowly changing procedures and attitudes in the courtroom; they are found in the fears the 1680s had taught the politicians about the dangers of using treason as a political weapon." Phifer, supra note 157, at 256. Bur see Rezneck, supra note 157, at 9-13 (arguing that a slowly emerging pattern of reforms in the 17 th century culminated in the 1696 act). 
function by declaring certain witnesses to be likely liars as a matter of law. Exactly when the rules evolved is unclear. Wigmore traced the rule barring civil parties to the sixteenth century and that barring all other interested persons to the mid-seventeenth century. ${ }^{204}$ But it seems that these dates merely mark the earliest references Wigmore could find; the rules may well have been older. Barbara Shapiro notes that the rules bear a close, if simplified, resemblance to the testimonial disqualifications that prevailed in the Roman-canon law of the Continent. ${ }^{205}$

There is no doubt as to the rules' rationale. All sources agree that they sought to keep from the witness stand anyone whose temptation or inclination to lie was greater than average. The most famous statement of the principle is Gilbert's. He wrote in the early eighteenth century that excluding such witnesses would serve the truth and protect the witnesses:

Men are generally so short-sighted, as to look at their own private Benefit which is near to them, rather than to the Good of the World that is more remote; therefore ... the Law removes them from Testimony, to prevent their sliding into Perjury; and it can be no Injury to Truth, to remove those from the [hearing of the] Jury, whose Testimony may hurt themselves, and can never induce any rational belief. ${ }^{206}$

Gilbert's elegant and often-quoted image of witnesses "sliding into Perjury" has overshadowed his more important defense of the competency rules-that by keeping likely liars from the witness stand, they protected the presumption that all sworn evidence is truthful. Here is Gilbert's explanation of the competency rule that barred convicted felons:

[E]very plain and honest Man affirming the Truth of any matter under the Sanction and Solemnities of an Oath, is intilled to Faith and Credit, so that under such Attestation the Fact is understood to be fully proved.

But where a Man is convicted of Falshood and other Crimes against the common Principles of Honesty and Humanity, his Oath is of no Weight ... [and] this Presumption fails him . . . .

204. See 2 WIGMORE, supra note 44, $\$ 575$, a 679-80. Michael Macnar thinks Wigmore dates the disqualification of parties too early and the disqualification of interested persons 100 late. See Michael Richard Trench Macnair, The Law of Proof in Early Modern Equily 232-56 (1991) (unpublished Ph.D. dissertation, University of Oxford) (on file with author). I thanh John Lungbein for poinung me to this work. For an interesting analysis of both of these compelency rules, see James Oldham. Truth-Telling in the Eighteenth-Centun' English Courtroom, 12 LAw \& HIST. REV. $95.107-17$ (1994).

205. See SHAPIRO, supra note 28 , at 188-90.

206. GILBERT, supra note 70, at 122.

207. Id. at 142-43; see also Macnair, supra note 204. at 250.51 (discussing the reiallonship between competency rules and the presumption that swom evidence is true). 
In Gilbert's formulation, competency rules did the work of lie detecting, so the jury did not have to. The result, in Stephen's words, was that "[i]f the court regarded a man as 'a good' (i.e. a competent) 'witness,' the jury seem to have believed him as a matter of course, unless he was contradicted."208

Alongside this gantlet of witness competency rules, another rule of evidence helped to protect juries from ever having to call anyone a perjurer. The prosecution of Slingsby Bethel for assault and battery in 1681 provides the earliest example I have seen of this rule. ${ }^{209}$ The government had charged Bethel, who was standing as a candidate for Parliament, with striking a servant of the King outside the polling place. ${ }^{210}$ Because the charge was a misdemeanor, Bethel had the right to call sworn witnesses. After the Crown had called six witnesses who swore they had seen Bethel strike the other man, ${ }^{211}$ Bethel called five witnesses to swear that they had been present at the time of the alleged attack and had seen no such thing. ${ }^{212}$ Bethel, who was represented by counsel, ${ }^{213}$ gave no account of events.

In his closing statement to the jurors, the King's counsel (and later chief justice of the King's Bench), Sir John Holt, reasoned with them in this manner:

[I]f you acquit Mr. Bethel, you must necessarily Convict Eight [sic] Persons of Perjury: But if you do not find for Mr. Bethel, the other Witnesses cannot be Convicted of Perjury; for how can Men swear, (though they were there all the time) that they did not see? possibly they may be very honest Men, and present at the time, and yet not see Bethel strike, and so not swear to it. ... I do appeal to the Court, whether in matters of this Nature, one Witness for the Affirmative, be not more valid than many of the Negative? ${ }^{214}$

Seconding the prosecutor's reasoning, the presiding magistrate ${ }^{215}$ instructed the jury that "one Affirmative was better than Forty Negative Oaths." 116 The jury returned a verdict of guilty. ${ }^{217}$

208. I STEPHEN, supra note 28 , at 400 .

209. See THE TRYAl OF SLINGSBY BEthel ESQ., supra note 14, at 9.

210. See Preface to id. (unpaginated).

211. See id. at 3-5. The Crown's witnesses varied wildly. Mason, the alleged victim, said Bethel hit him with a cane and fists and delivered at least 20 blows. See id. at 3. Another witness said Bethel "thrust" Mason down the stairs. Id. at 4. Four mentioned mere "shrugs" or "pushes." ld. at 3-5. A seventh mentioned no blow at all, just threatening words. See id. at 5 .

212. See id. at 6-8.

213. See id. at 5 .

214. Id. at 9.

215. The transcript identifies the person who delivered the charge as "Justice Pyrs" without elaboration. Id. at 10. As this misdemeanor trial took place at the local court of quarter sessions, we should expect that a justice of the peace presided.

216. Id.

217. See id. 
Holt stated the rationale behind the rule: Jurors should if possible avoid calling anyone a perjurer. ${ }^{218}$ That principle was simply a corollary of the presumption that sworn evidence was true-a presumption expressed time and again by courts and commentators of the sixteenth through nineteenth centuries. $^{219}$ In this context, it meant that the jury should conclude that one witness was mistaken (or inattentive) before concluding that either had lied. A jury trying to obey this admonition almost always would have to favor affirmative over negative evidence because, as Holt argued to the jury, witnesses who say something happened are much less likely to be mistaken than those who say it did not happen.

That the magistrate's breezy aphorism-"one Affirmative [is] better than Forty Negative Oaths"-sounds so well worn suggests that Bethel's Case by no means marked the rule's first application. 220 But though the rule seems to have roots in Roman-canon law, ${ }^{221}$ it is difficult to find examples of the rule in common law cases before 1696. Until passage of the Treason Act, only misdemeanor cases presented the possibility of a sworn conflict between prosecution and defense witnesses-and few misdemeanor cases had sufficient celebrity to be recorded in great detail. We are fortunate to know of Bethel's Case only because a man of distinction was so rash as to cuff an emissary of the King. I have found one other, somewhat more obscurely phrased example

218. This simple proposition appears often in early case reports, even outstde the context of testumonial conflicts. For example, at Coleman's trial for treason, the prosecutor. Altomey General Sir Willtam James. told the jurors they "must find the prisoner guilty, or bring in two persons perjured "KEvYov, supra note 162 , at 125 (quoting James).

219. Wigmore cites the following 16th-, 17th-, and 18th-century examples Duke of Norfolk's Trual. Jardine's Crim. Trials I 178 (1571) (stating that. when the defendant attacked the credil of a swom government witness, Serjeant Barham said, "He is swom, there needeth no more provang"). Lord Russell's Trial, 9 Howell's State Trials 577, 618 (1683) (Pemberton. CJ.) (“If you cannot contradict them by testimony, it will be taken as a proof."); and $R .1:$ Muscor. 10 Mod. 192 (1715) (Parker. C J ) ("IA] credible and probable witness shall tum the scale in favor of either party."). See Wigmore, supro note 43 , at $89 \mathrm{n} 2$. cf. 9 HoldswORTH, supra note 43, at 208-09 (arguing that the rule that barred parties from impeaching their own witnesses was a manifestation of the presumption that swom evidence was (rue). I STEPtiEv. supra note 28, at 399-400 ("[T]he opinion of the time seems to have been that if a man came and swore to anything whatever, he ought to be believed unless he was directly contradieled The junes seem to have thought (as they very often still think) that a direct unqualified oath by an eye- or ear-witness must be believed unless it is distinctly contradicted."). On 19th-century sourees. see infra notes 233-236 and accompanying text.

220. In the postscript to this edition of the trial. the anonymous reponer. who was an admited pantisan of Bethel, wrote:

Mr. Recorder not being at the Court, he who in has absence gave Directions to the Jury. told them. That they had Mason's positive Oath, that One Affirmatuve was better than Fony Negative Oaths, and therefore they must either find Bethel Gully. or they would make Mason [the complainant] perjured. Which passing for Law with the Jury, they brought him in Guilty of the Assault and Batterie.

THE TRYAL OF SLINGSBY BETHEl ESQ., supra note 14, at 12. The editor's snide remark that the prnnciple "pass[ed] for Law with the Jury" makes me hesitate to claum that the rule was rell known at this date. Still, the ready concurrence of the magistrate with the King's counsel and the similanty of their langunge suggests they were citing a principle familiar to them both. In any event, as I hope to show shortly. the evidence that the rule would soon be commonly accepted is quite strong.

221. See MiChael MaCNaIR, The Law OF PROOF IN EARLY MODERN EquTr (forthcoming 1998) (manuscript at 276-77, on file with author). 
of Bethel's rule in the celebrated 1684 trial of Dr. William Sacheverell for riot. ${ }^{222}$ But I can cite no other early case. ${ }^{223}$

Shortly after the turn of the eighteenth century, however, Jeffrey Gilbert gave Bethel's rule a very prominent platform. Gilbert devoted a section of his famous evidence treatise specifically to the problem of "contrary Proofs."224 He began that section with a remarkably broad statement of Bethel's rule, together with a remarkably transparent statement of its rationale:

In contrary Proofs if Men's swearing can be reconciled, such Interpretation shall be put upon it as may make them agree, because every body shall be supposed to swear the Truth, and no Man shall be intended to swear a manifest Perjury; therefore that Construction shall be taken that would make them agree, rather than such whereby they must necessarily oppose each other.

One affirmative Witness countervails the Proof of several Negative, because the Affirmative may swear true, and the Negative also; for the Negatives may commonly be, that they know not of the Matter; the affirmative swears that it is, and so the Affirmative may be true and the Negative also .... ${ }^{225}$

Echoing Holt's argument in Bethel's Case, Gilbert held that the jury should, if possible, reconcile competing oaths. Again we see, this time in very frank terms, the presumption that all oaths are true. And Gilbert, like the magistrate in Bethel's Case, announced that a necessary corollary of the rule is that affirmative evidence should trump negative.

Gilbert's great influence and his clear statement of Bethel's rule guaranteed it lasting and distant prominence. His treatise was the dominant evidence text of the eighteenth century. ${ }^{226}$ For a century after he wrote, the major writers

222. Chief Justice George Jeffreys charged the jury:

[Y]ou must believe all the witnesses for the king actually perjured, unless you believe their evidence; and [as] for what others say, that they did not hear such and such things, yet all these other people did hear, and though the witnesses for the defendants did not see, the others did see; and you must find these men without any evidence that does appear, to be guilty of wilful perjury, or else every person that you have had in charge ... is guilty of the riot whereof they have been informed against.

Trial of Sacheverell, 10 Howell's State Trials 29, 95 (1684).

223. A fundamental principle of Bethel's rule, however-that the jury should try to reconcile evidence that seems to conflict-does appear in other early cases. See, e.g., Trial of Purchase, 15 Howell's State Trials $651,690(1710)$ (reporting the court's instruction to the jury that "[i]f the witnesses do not contradict one another, but they may be reconciled, you need not then weigh which side you most credit"); Trial of Dammaree, 15 Howell's State Trials 521, 602 (1710) (reporting the court's instruction to the jury to "consider how far [the witnesses] are to be reconciled; for if there is a way to reconcile them all, that will be an inducement to you to believe they all speak right").

224. GILBERT, supra note 70, at 156. On the timing of publication of Gilbert's evidence treatise, see supra note 161 .

225. GILBERT, supra note 70, at 156-57 (emphasis added). Gilbert repeats the point in another context: "[T] obtains Credit, unless there be some Appearance of Probability to the contrary." Id. at 150.

226. See THAYER, supra note 47, at 2 n.2; Stephan Landsman, From Gilbert to Ben/ham: The Reconceptualization of Evidence Theory, 36 WAYNE L. REV. 1149, 1152 (1990). 
on evidence largely elaborated on his work. ${ }^{27}$ To judge from John Adams's legal papers, Gilbert was the only authority on evidence that practitioners in late-eighteenth-century Massachusetts bothered to cite. To them, Bethel's rule was simply "[t]he Rule about positive and Negative Witnesses."22s The first comprehensive evidence treatise after Gilbert's, that of John Morgan in 1789. repeated Gilbert's formulation of Bethel's rule almost word for word. ${ }^{229}$ Although Bethel's rule turned up missing in the respective treatises of Peake and Phillipps in 1801 and $1814,,^{230}$ it appeared in those of Evans, Starkie, and Rapalje in 1806,1824 , and $1887 .^{231}$

227. Morgan's 1789 work lifted large chunks from Gılbert, as Morgan unabashedly admulted See I JOHN MORGAN, ESSAYS UPON THE LAW OF EvidenCE at vil (Dublın. Mcssr. E. Lynch et al 1789) Pcakc's treatise of 1804, see PEAKE, supra note 112, and Phillipps's treatise of 1815. see PhilL.1Pps. supra note 112. tracked Gilbert less closely but closely still.

228. 2 Legal PAPERS OF John ADAMS $90 \mathrm{n} .75$ (L. Kinvin Wroth \& Hiller B Zobel eds, 1965). see also id. at 8 n.24, 60 n.5 (referencing Gilbert); 1 rd. at 134 n. 56 (sime)

229. See 1 MORGAN, supra note 227, at 46.

230. Peake and Phillipps did comment on affirmatuse and negatuse evidence in ways that echo strains of Bethel's rule. Peake noted that because a negative does not admit of direel proof, the pany who denies a fact can remain silent until the adversary has offered evidence to prove 1t. See PEAKE, supra note 112. at 5. Similarly, Phillipps wrote. "The Affirmative of the Issue is to be proved." Pitlu.ups. supra note 112. at 150 . The principle that it is hard to prove a negative shares a common intultion with Bethel's rule that a person who claims something did not happen might simply have mussed it They are not, however, the same thing.

231. Evans's work appeared as an appendix to Pother's Treatuse on the Law of Obliganons See William David Evans, On the Law of Evdence. Appendux $X V$ t to $M$ [ROBERT JOSEPii] POTIIER. A TREATISE ON THE LAW OF OBLIGATIONS. OR CONTRACTS (William David Evans ed . London. A Siratian 1806). Evans wrote that "the preference of positive to negalus evidence" rests on a recognition thal "il is much more probable, that a person may not have observed an occurrence which actually did take place, or having observed it, may not have recollected It. than that another should imagine circumstances which had no foundation in existence." $l d$. at 248 . Later, he added that " $[w]$ here the possibility of mimstake on the one side is contrasted with the imputation of perjury on the other. and there are no collateral cireunstances to fix the determination, there can be no doubt but that a casual error is to be decmed more probable than a wilful misrepresentation." Id. at 264. Although Evans achnowledged the presumpition of iruthfulness on which Bethel's rule relied. he subseribed to it "in the abstract" and seemed sheptical Id at 236-37, 262

Starkie, on the other hand, produced an enthusiastuc and influentual treatment of Bethel's rule, frankly staked on the presumption of truth. See mfra notes 233-237 and accompanying text

Rapalje restated the rule, but pehaps did not endorse it. See STEWART RAPALE. A TREATISE: ON TIE LAW OF WITNESSES § 193, at 319 (Albany. Banks \& Bros. 1887) (“Another general nule for weighung testimony is that the testimony of one witness who speaks posituvely and affirnatuvely to a fact is entulled to more consideration than that of several equally credible witnesses who (estify negatuvely only "), $u$. \$ 195, at 324 (suggesting that the jury should reach the question of "which of the witnesses are the more worthy of belief" only if the "testimony of different witnesses cannot be hamnonized") Rapalje saud at the outset of his work that he meant merely to review the cases as they stand, not to say how the law should be. See id. at iii.

In the third volume of his important treatise, published in 1853. Simon Greenleaf remarked that "It has been judicially said, that ... the positive testumony of one eredible winess to a fact is enutled to more weight than that of several others who testify negaltvely." 3 SIMON GREENLEA. A TREATISE OV THE LAW OF EVIDENCE $\$ 375$, at 380 (Boston, Litule, Brown \& Co. 1853) But this text appears in a section of the work devoted to proceedings in equity. Greenleaf does not appear to extend the rule to jury inals

Bethel's rule found one last 19th-century restatement in Jones's 1896 treatise. devoted to evidence

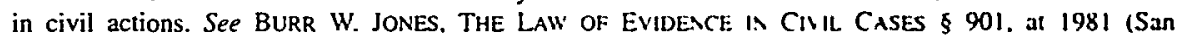
Francisco, Bancroft-Whitney Co. 1896) ("[T]he posituve testumony of a single witness is entuled to more weight than that of several witnesses, equally credible. who testifs negaltively ") Jones's qualification that the rule "should never come in conflict with the general rule that the wetght of the iesumony should be left to the jury," id., typified, as we will see, Bethel's rule in its late-19th-century decline. see tnfra notes 275-278 and accompanying text. 
I have not succeeded in tracing the passage of Bethel's rule to America. Adams's papers are the earliest American reference I have found. It is likely the rule was swept in with the rest of the English common law, which had governed in the colonies and which all but two of the young states embraced in whole or part in the years after the Revolution. ${ }^{232}$ In any event, nineteenth-century American judges applied Bethel's rule liberally. When they invoked it, the authority they most often cited was Thomas Starkie's $A$ Practical Treatise on the Law of Evidence. ${ }^{233}$ Like Gilbert, Starkie explicitly embraced the presumption underlying Bethel's rule that all sworn evidence is true, a presumption that remained current in the nineteenth century. ${ }^{234} \mathrm{~A}$ witness's credibility stands "upon experience of human veracity," Starkie wrote, "from which the law presumes that a disinterested witness who delivers his testimony under the sanction of an oath, and under the peril of the temporal inflictions due to perjury, will speak the truth." 235 Starkie then offered this elaborate statement of Bethel's rule and its rationale:

In cases of conflicting evidence the first step in the process of inquiry must naturally and obviously be to ascertain whether the apparent inconsistencies and incongruities which it presents, may not without violence be reconciled ....

... [H]ere it is to be observed, that there is an important distinction between positive and negative testimony.

... If one witness were positively to swear that he saw or heard a fact, and another were merely to swear that he was present, but did not see or hear it, and the witnesses were equally faith-worthy, the general principle would in ordinary cases, create a preponderance in favour of the affirmative; for it would usually happen that a witness who swore positively, minutely, and circumstantially, to a fact which

232. See Elizabeth GaSpar BROWN, BRITISH STATUTES IN AMERICAN LAW 1776-1836, at 21-26 (1964). The two exceptions were Rhode Island and Connecticut, which did not embrace English common law until 1798 and 1818 , respectively. See id. at 24 \& n.4.

233. Thomas Starkie, a Practical Treatise on the Law of Evidence (Boston, Wells \& Lilly 1826). Cases explicitly relying on Starkie include Harris v. Bell, 27 Ala. S20, 522 (1855); Matthews v. Poythress, 4 Ga. 287, 295-96 (1848); and Hepburn v. Citizens' Bank, 2 La. Ann. 1007, 1008-09 (1847). Many cases repeated Starkie's justification of the rule nearly word for word, but without citation. See, e.g., Johnson v. Scribner, 6 Conn. 185, 188 (1826); Delk v. State, 40 Tenn. (3 Head) 79, 81 (1859).

234. An 1882 edition of Best's treatise stated flatly: "All testimony given in a court of justice is presumed to be true until the contrary appears. ... [T] he law will not presume irreligion,.... and consequently will not presume intentional false swearing." W.M. BEST, THE PRINCIPLES OF THE LAW OF EVIDENCE 628 (Jersey City, Frederick D. Linn \& Co. 1st American from 6th London ed. 1882) (1849). An Oregon statute on the books in 1863 said, "A witness is presumed to speak the truth." OR. CODE CIV. P. $\S 673$ (1863). The statute then specified that this presumption was rebuttable and noted that "where the trial is by the jury, they are the exclusive judges of [the witness's] credibility." Id. Writing toward the end of the century, Stephen remarked without approval that "juries do attach extraordinary importance to the dead weight of an oath." 1 STEPHEN, supra note 28, at 401 . In State v. Jones, 77 N.C. 520 (1877), the North Carolina Supreme Court held that a trial judge was inaccurate to tell a jury that "it is a rule of lav, a presumption that men testify truly and not falsely." ld. at 521 (emphasis in original). The court said that "[a] Judge may properly instruct the jury, that the law presumes, and that they should presume, that a witness speaks the truth, unless there be some reason for thinking otherwise." $I d$.

235. I STARKIE, supra note 233 , $\S \mathrm{LVI}$, at $* 455$. 
was untrue, would be guilty of perjury, but it would by no means follow that a witness who swore negatively would be perjured, although the affirmative were true; the falsity of the testimony might be attributed to inattention, mistake, or defect of memory .... It follows, therefore,... that in such cases, unless the contrary manifestly appear, the presumption in favour of human veracity shall operate to support the affirmative. ${ }^{236}$

The popularity of Starkie's treatment of the rule owed something to the example he next presented:

If, for instance, two persons should remain in the same room for the same period of time, and one of them should swear that during that time he heard a clock in the room strike the hour, and the other should swear that he did not hear the clock strike, it is very possible that the fact might be true, and yet each might swear truly. ${ }^{23}$

Starkie's conclusion that "the presumption in favour of human veracity shall operate to support the affirmative" proved unexpectedly helpful to the well-paid lawyers of later decades who sought to defend their railroad clients against scores of claimants who swore they did not hear the train that injured them sound its bell. ${ }^{238}$

Partly because of the huge number of claims against railroads, most of the many nineteenth-century citations to Bethel's rule appear in civil cases. ${ }^{239}$ The rule's latter-day vitality influenced criminal cases as well, however, and trial judges in particular seem to have adhered to it. An Illinois trial judge advised a jury in 1857 that ".'[i]f the jury believe, from the evidence, that Higgins [and others] are truthful witnesses, and that they swear positively to the fact that the defendant struck Higgins, such positive evidence should receive more consideration than any negative evidence there may be in the case." 240 In a Georgia prosecution of 1853, a defense witness swore he had

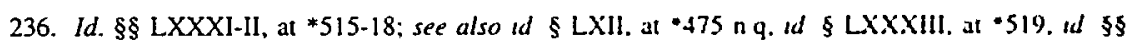
LXXXIX-XC, at *530-31.

237. Id. at $* 517$.

238. Railroad cases include Horn v: Balimore \& Oho Railroad. $54 \mathrm{~F} 301.305$ (6th $\mathrm{Cir} 1893$ ). Chicago \& Alton Railroad v: Robinson, 106 Ill. 142, 145-16 (1883). Chucago \& Rock Istand Ruslroad v Still, 19 Ill. 499, 509 (1858); Missouri Pacıfic Rallway v: Pierce. 39 Kan. 391.395 (1888). Van Panten v Schenectady Street Railway, 80 Hun. 494, 496 (N.Y. 1894): Culhane v. New York Central \& Hudson Railroad, 60 N.Y. 133, 137 (1875); and Unas v: Pennsyluanta Raslroad. 152 P3. 326. 328 (1893)

239. See sources cited supra note 238. Non-ralroad cases include Abbe r Rockl. I F Cas 7. 8.9 (C.C.D. Mich. 1854) (No.6) (assertion of authonty to execute promisson notes). Kenned, \& Kenneds. 2 Ala. 571, 616 (1841) (statement of deceased): Johnson : Scribner. 6 Conn 185. 188.89 (1826) (alleged slander); Mathews v: Poyhress, 4 Ga. 287, 295-96 (1848) (reieipt of consideration). Hepburn v. Ciltens" Bank, 2 La. Ann. 1007, 1008-09 (1847) (bank deposit): Sanger V Vanl. 13 How Pr (n s) 500, 500 (N Y Sup. Ct. 1856) (exception at trial); and Frant: v: Lenhart. 56 Pa. 365.367 (1867) (batten)

240. Coughlin v. People, 18 Ill. 266, 267 (1857) (quoung the Inal judge's instructuons) The Illinois Supreme Court reversed the conviction for reasons 1 will diseuss shortly See infra text accompany ing note 271. 
been at the scene of an alleged rape at the time the complainant swore the crime took place and yet he had not seen either the complainant or her alleged attacker. ${ }^{241}$ The trial judge told the jury, in terms reminiscent of Bethel's Case, " $[t]$ hat if one witness of equal knowledge and credibility swears positively to a fact, and fifty swear negatively, that they did not see or know the fact, the one witness swearing positively, and not contradicted, is to be believed in preference to the fifty." ${ }^{242}$ In upholding the charge, the Georgia Supreme Court reasoned that "[a] mistake of an hour in this regard [as to who was where and when] would create no contradiction in the evidence, nor tend in the least to impeach the veracity of either of the witnesses." 243

There are many signs that Bethel's rule held its vitality deep into the nineteenth century and in some places well into the twentieth. In 1873, the United States Supreme Court approved a trial judge's instruction that the jury should prefer affirmative to negative evidence because the person "who testifies to a negative may have forgotten."244 "We are of the opinion," said the Court, "that the charge was a sound exposition of a recognized rule of evidence of frequent application ...."245 In 1897, a federal appeals court approved a charge under the rule in a criminal case. ${ }^{246}$ And in 1905 , the North Carolina Supreme Court restated the rule together with its original rationale. ${ }^{247}$ Georgia and Louisiana adopted the rule by statute-Georgia in $1895^{248}$ and Louisiana in $1926^{249}$-and it remains on the books in both states. ${ }^{250}$ In 1900, West Publishing Company produced the Century Edition of the American Digest, a precursor to modern case digests. In chapter XIV of the materials on evidence, titled "Weight and Sufficiency," the first heading

24I. See Johnson v. State, 14 Ga. 55, 63 (1853).

242. Id. at 62 .

243. Id. at 63; accord Cobb v. State, 27 Ga. 648, 685-86, 699 (1859).

244. Stitt v. Huidekopers, 84 U.S. (17 Wall.) 384, 394 (1873).

245. Id.

246. See Rhodes v. United States, 79 F. 740, 743-44 (8th Cir. 1897).

247. See State v. Murray, 51 S.E. 775,775 (N.C. 1905). The court approved the following charge to the jury:

The reason the law gives greater weight to positive testimony than to negative testimony is because the witnesses who swore to positive testimony swore to what is a fact, an existing fact, or eise they deliberately swore to a falsehood, while those who swore to negative testimony may Id.

be telling the truth, and yet the fact may exist which they did not see.

248. See An Act To Improve, Adopt and Make of Force the Code of Laws Prepared Under the Direction and by Authority of the General Assembly, To Provide for the Printing and Publication of the Same, and for Making Indices Thereto, and for Other Purposes, No. 189, 1895 Ga. Acts 98 (codified at GA. CODE ANN. \$ 24-4-7 (1995) (original version at GA. CODE $\$ \$ 985,5165$ (1895))) ("The existence of a fact testified to by one positive witness is to be believed, rather than that such fact did not exist because many other witnesses who had the same opportunity of observation swear that they did not see or know of its having existed ....").

249. See Act of Nov. 2, 1926, No. 2, 1928 La. Acts 3 (codified at LA. REv. STAT. ANN. \$ 15:440 (West 1981)) ("Positive testimony on a given point must be given greater weight than negative testimony on the same point.").

250. Georgia has not eliminated the rule, although case construction long ago greatly limited its application-a point I will discuss below. See infra notes 276-277 and accompanying text. 
after that labeled "In General" is called "Positive and Negative Testimony."251 Five double-columned pages of case squibs follow, many dated in the $1890 \mathrm{~s}^{252}$ One section heading reads, "Positive testimony of one against negative testimony of several."253

The Encyclopadia of Evidence of 1906 likewise devotes a seven-page chapter to the topic, "Positive and Negative Evidence."ss This late work includes a corollary to Bethel's rule that carries the rule's strained logic to a surprising conclusion: "Negative testimony ... must, in order to have any weight as evidence, tend to contradict positive testimony of the other party." 255 The treatise writers evidently reasoned that since the first principle of Bethel's rule was to reconcile competing oaths whenever possible, there was no point even in admitting negative testimony unless it was irreconcilable with the affirmative testimony. ${ }^{256}$ As late as 1920 , the Missouri Supreme Cour relied on this treatise in holding that a trial judge rightly refused to let an accused murderer call twelve local druggists to say that they had not sold the defendant strychnine. ${ }^{257}$

I go on at some length about the apparent ubiquity and longevity of Bethel's rule in part because of Wigmore's response to the Missouri case last cited. The Missouri court, he said, "allow[ed] itself to be entrapped by an anonymous treatise." 258 That is not quite right, as the court did cite the treatise, if with a slightly misleading abbreviation: "Cyc. of Ev." ${ }^{\text {"2s9 }}$ It is hard to believe that Wigmore had not heard of this treatise, which was printed in his day (but which, to be fair, was not on the shelves of his law school's library $\left.{ }^{260}\right)$. His next sentence, remarking on the court's borrowed assertion that "[n]egative evidence is admissible only if it tends to contradict positive evidence introduced by the other party," sounds somewhat disingenuous: "[W]here this preposterous fallacy started is not worth investigation."261 "[F]rom some source not traceable," he protested, "there lingers in the judicial mind, in many quarters, an antiquated notion that negative impressions are not so probative as affirmative impressions; and a charge to the jury often

251. 20 CENTURY EDITION OF THE AMERICAN DIGEST $\S 2432$, al 3574 (1900).

252. See id. §§ 2432-35, at 3574-83.

253. Id. $\$ 2435$, at 3582 .

254. 9 ENCYCLOPEDIA OF EVIDENCE $864-70$ (Edgar W. Camp \& John F. Crowe eds . 1906).

255. Id. at $865-66$.

256. A Connecticut court remarked in 1826 that negative evidence of the son treated by Bethel's rule was "no evidence in effect." Johnson v. Scribner, 6 Conn. 185. 189 (1826). Gilben himself seems to have endorsed this extension of Bethel's rule. In a somewhat different context. he wrote that once the affirmalive of an issue has been made out, the defendant "can only prove a Proposition inconsistent with the Charge. [as] that he was at another Place at the Time when the Fact is supposed to be done, or the like." GiLBERT. supra note 70, at 148 .

257. See State v. Smith, 222 S.W. 455,459 (Mo. 1920).

258. 2 WIGMORE, supra note $44, \S 664$, at $780 \mathrm{n} .1$.

259. Smith, 222 S.W. at 459.

260. I am grateful to the staff of the Norhwestern Law School library for this information

261. 2 WIGMORE, supra note $44, \S 664$, at $780 \mathrm{n} .1$ 
embodies that notion, where the witnesses differ." 262 Wigmore later claimed ignorance not only of the source of this well-footed rule, but also of any rationale: "Modern psychology sneers at the law's crude assumption that the complexities of human perception can be handled by some rules of thumb about negative testimony or the like."263

As I hope I have shown, it is really not so hard to pin down the source and the point of Bethel's rule. It is true that Bethel's Case itself is reasonably obscure. But Wigmore certainly knew well the treatises of Gilbert and Starkie, ${ }^{264}$ who discussed the rule prominently and explained its rationale. Moreover, even as Wigmore denied knowing any possible rationale for the rule, he cited cases that explained the point of the rule as avoiding attributions of perjury. ${ }^{265}$ It seems at least plausible that Wigmore chose to ignore these sources because he preferred to dismiss the rule as "a discredit to the science of law, [which] should be discarded." ${ }^{266}$ After all, the rule derived its power from a presumption that all oaths were truthful and from a lack of faith in the jury's power to choose between sworn witnesses. Wigmore preferred to insist that "the rule of law ... has really nothing to say" about conflicts of oaths. ${ }^{267}$ Such conflicts simply "go to the jury for determination." $268 \mathrm{He}$ declined to acknowledge that the old law of evidence did not trust the jury that far.

It is true that, by Wigmore's day, Bethel's rule had lost most of its vitality. The reader may already have noted two shifts in emphasis in the various statements of the rule quoted above. The first concerned the rule's essential precondition that one witness might be mistaken. Gilbert had noted that the rule does not work if "Affirmative and Negative oppose each other in contradictory Propositions." 269 That is, if the jury could not call someone mistaken, it would have to call someone a liar. The earlier cases, including Bethel's Case itself, seem to have interpreted this requirement loosely. Only in legal fiction could all five of Bethel's witnesses have been mistaken when they denied seeing the blows that the government's witnesses said they had seen. By allowing the possibility of mistake (or misperception) where none was likely, courts gave the rule broader application.

262. Id. at 781 . In a footnote, Wigmore adds: "A rule-of-thumb for measuring testimonial weight has here grown up in some jurisdictions: "Where two witnesses, unimpeached, contradict each other, the presumption is in favor of the witness who swears affirmatively ...." Id. at 781 n.2.

263. Id. at 782 .

264. For references to Gilbert's treatise, see, for example, 1 id. $\S 136$, at $570 ; 2$ id. $\S 519$, at 609; id. $\S 576$, at $686 ; 3$ id. $\S 826$, at 255 n.1; id. $\$ 994$, at $632 ;$ id. $\S 1006$, at $670 \mathrm{n} .1$; and id. $\S 1017$, at 686 . For references to Starkie's treatise, see, for example, 6 id. $\$ 1831$, at $330 ; 7$ id. $\$ 1917$, at $2 ;$ id. $\$ 1982$, at 150 n.8; id. § 1992, at 179 n.3; id. § 2094, at 469 ; and 8 id. $\S 2190$, at 60 n.25.

265. See, e.g., Matthews v. Poythress, 4 Ga. 287, 295 (1848), cited in 2 WIGMORE, supra note 44 , 664 , at 780 n.l.

266. 2 WigMORE, supra note $44, \S 644$, at 782 n.2.

267. Id. at $781 \mathrm{n} .2$.

268. Id.

269. GILBERT, supra note 70 , at 157 . 
In the nineteenth century, however, courts seemed to be more inclined to confine the rule to its purported rationale. If one witness swore to having seen something and another swore to having watched carefully and not seen it, courts generally concluded that this was a conflict between two affirmative witnesses and hence outside the rule. In the 1857 case from Illinois mentioned earlier, ${ }^{270}$ for example, the trial court delivered an instruction echoing that of Bethel's Case. The state's supreme court reversed the defendant's conviction. It reasoned that if the defendant's witnesses, who denied seeing the event in question, were as "likely to know and remember the facts" as the government's witnesses, then "[ $t$ ]heir testimony" was as positive, as to the fact in controversy."271 Likewise, the Georgia statute that codifies Bethel's rule provides that " $[t]$ his rule shall not apply when two parties have equal facilities for seeing or hearing a thing and one swears that it occurred while the other swears that it did not."272 There were, to be sure, counterexamples to this countertrend. In 1873, the Wisconsin Supreme Court held that Bethel's rule should have applied even though the "negative" witness swore she was "very sure" the event in question had not happened, and she was in a position to know. ${ }^{273}$ On the whole, however, nineteenth-century courts were growing less inclined to call witnesses who denied events "negative" witnesses." 74

These courts also grew more likely to impose a condition on the rule that undermined its fundamental rationale. This was the second shift in the

270. See supra note 240 and accompanying text.

271. Coughlin v. People, 18 IIl. 266, 267-68 (1857); accord Comell v Hyatt. 6 F Cas 569.572 (C.C.D.C. 1856) (No. 3237); Harris v. Bell, 27 Ala. 520. 521.22 (1855). Allanta \& W PR R 、 Johnson. 66 Ga. 259, $271-72$ (1881); Kansas City. F.S. \& G R.R. v Lane, 33 Kan 702, 706.07 (I885). State v Chevallier, 36 La. 81, 83-84 (1884); Bradley v. Mutual Benefil Life Ins. Co. 45 N Y \$22. 429 (1871). Reeves v. Poindexter, 53 N.C. (8 Jones) 308, 309-11 (1860).

272. GA. CODE ANN. \$ 24-4-7 (1995); see also RAPAL.JE, supra note 231. \$193. at 320 (stalung that where two witnesses listen equally closely and one swears to heanng a statement and one denies it was said, "[t]his is a direct contradiction, and the rule does not apply"). I STakXIE:, supra note 233. \$ LXXXII. at *518 ("The application of this prnciple supposes that the posituve can be reconciled with the negatuve without violence and constraint.").

273. Ralph v. Chicago \& N.W. Ry., 32 Wis. 177. 179. 181-82 (1873) The coun staked its deciston on the classic rationale of the rule: The affirmative wilness "elther did [as he sand). or he has probably committed perjury." Id. at 181. In the case of the negative witness. "There is much more room for fature of recollection." Id. at 182. The Wisconsin court, however, soon followed the general trend See Shekey v. Eldredge, 37 N.W. 820 (Wis. 1888).

274. Courts often tortured the language to insist that witnesses who claımed an event did not occur. but asserted this with enough assuredness, were "positive" or even "affimaluve" witnesses Acknowledging "confusion" on this point, the Wisconsin Supreme Court offered the following clantication in 1909

For instance, testimony that the bell in the elevator did not nng, contrary to the evidence that it did ring, is negative in form but is an affimation of fact that the bell did not nng it is as affirmative as the evidence that the bell did ning. One affirms the bell rang. the other that it did not.

Anderson v. Horlick's Malted Milk Co., 137 Wis. 569, 574 (1909). see also. e g . Willuams v Statc, 23 Ga. App. 542, 542-43 (1919); Heywood v. State. 12 Ga. App. 643. 643 (1913); Fnzell v Cole, 42 III 362.363. 65 (1866); 9 ENCYCLOPEDIA OF EVIDENCE, supra note 254, at 865 ("Posilure Evidence of a Negative.-Direct testimony that an event did not occur. or that a matter is not so is positive. and not negative." (citing cases)); RAPALJE, supra note 231. § 193. at 321 ("Sometımes testımony negalive in fact is held to be affirmative within the rule ....). 
application of Bethel's rule: Many nineteenth- and twentieth-century courts held that affirmative evidence would trump negative only " $[w]$ here witnesses are equally credible."275 In a line of cases beginning in $1896,{ }^{276}$ the Georgia Supreme Court robbed that state's statutory formulation of Bethel's rule of most of its power by specifically reassigning the task of lie detection to the jury:

It is error to charge without qualification that positive evidence is stronger than negative .... In weighing evidence, its character as to being positive or negative is one element for consideration, but it is not the only one. Credibility is also essentially involved. The section of the code does not mean that the jury is bound to believe the positive evidence of one whose credibility is little or nothing, or who may have been successfully impeached or shown to be a perjurer, in preference to the evidence of many honest, upright witnesses of unquestionable credibility who had equal opportunity of observation, though their testimony may be negative.... [T] he jury [is to] consider not only what a witness swears, but also what credit is to be given to him as a witness. ${ }^{277}$

The rationale of Bethel's rule-to spare juries having to call someone a liar-could not survive court decisions that said the rule applies only after the jury has weighed witness credibility. Although it is possible to cite dozens of twentieth-century applications of Bethel's rule, ${ }^{278}$ it is safe to say that by the end of the nineteenth century the rule had lost its soul. Courts no longer understood its original bond with the principle that all sworn evidence should be presumed truthful.

Even as Bethel's rule disintegrated, however, its motivating principle that sworn evidence should be presumed truthful showed remarkable staying power. We see the resilience of the old presumption in the very long survival of a little-known rule that juries may not disbelieve the sworn testimony of a disinterested witness who has been neither contradicted nor impeached. This rule has a substantial history. In his 1789 evidence treatise, Morgan attributed to Lord Camden the notion that every witness "who is free from all interest in

275. 9 ENCYCLOPfDIA OF EVIDENCE, supra note 254, at 867; see also Draper v. Baker, 61 Wis. 450 , 454-55 (1884); RAPALJE, supra note 231, § 193, at 319-20; cf. Pence v. Chicago, R.I. \& Pac. Ry., 79 Iowa 389,399 (1890) (saying that the jury must consider the witnesses' "comparative credibility").

276. The first case was apparently Humphries v. State, $100 \mathrm{Ga}$. 260, 263 (1896). See also Warrick v. State, 125 Ga. 133, $141-42$ (1906); Southern Ry. v. O'Bryan, 115 Ga. 659, 660 (1902); Atlanta Consol. St. Ry. v. Bigham, $105 \mathrm{Ga}$. 498, 498 (1898).

277. Warrick, $125 \mathrm{Ga}$. at I41-42; accord Estill v. Estill, I49 Ga. 384, 384 (1919). The Gcorgia Court of Appeals went so far as to say that the rule, as set forth in the statute, "is so inaptly stated . . . that to instruct the jury in the language there given is ordinarily error." Phillips v. State, 57 S.E. 1079, 1079 (Ga. Ct. App. 1907).

278. See, e.g., McAllister v. Tucker, 88 So. 2d 526, 530 (Fla. 1956); Atlantic Coast Line R.R. v. Hodges, 84 S.E.2d 711, 712 (Ga. 1954); McIntosh v. Union Pac. R.R., 22 N.W.2d 179, 183 (Neb. 1946); Williams v. City of Pittsburgh, 37 A.2d 540, 542 ( $\mathrm{Pa}$. 1944). 
the fact he comes to attest ... deserves credit; nay, he is always believed, unless some other objection, besides character, is raised against his testimony."279

In 1826, Starkie noted that "[i]n ordinary cases, where a witness stands wholly unimpeached by any extrinsic circumstances, credit ought to be given to his testimony, unless it be so grossly improbable as to satisfy the jury that he is not to be trusted." "280 Improbable things often happen, Starkie continued, so "mere" (not gross) "improbability can rarely supply a sufficient ground for disbelieving direct and unexceptionable witnesses of the fact where there was no room for mistake." ${ }^{\text {281 }}$ In the middle of the nineteenth century, Best wrote that testimony under oath, and perhaps even statements without an oath. "ought to be heard and believed until some special reasons appear for doubt or disbelief." ${ }^{282}$ And in 1887 Rapalje made it clear that the rule is really a limitation on the jury's discretion as judge of credibility:

[A]n instruction by the court that [the jury] may disbelieve any testimony which, under all the circumstances of the case, is not credible, is too comprehensive, for the jury cannot be allowed to determine for themselves that other circumstances, not within legal contemplation, tending to impeach the witness, show that his evidence is impeached, and therefore entirely disregard it. ${ }^{283}$

A great many American courts of the late nineteenth and early twentieth centuries applied or approved the rule. ${ }^{284}$ Even more remarkably, as we will

279. 1 MORGAN, supra note 227 , at 254.

280. I STARKIE, supra note 233, § LXII, at *472-74; see also RAPALJE, supra nole 231. \$190. al 317 ("If the statements of ... a witness are grossly improbable. the jury may disregard his testumony even though uncontradicted and unimpeached.").

281. 1 STARKIE, supra note $233 . \S$ LXII, at *477; see also id. $\S$ LXXXIX. al *530.

282. BEST, supra note $112, \S 118$, at $* 147-48$.

283. RAPALIE, supra note $231, \S 191$, at $317-18$; see also \&d. $\$ 180$, at 306 (noung that a jury should not reject a witness arbitrarily). Rapalje earlier had suggesied his skepticism about the rule:

And whether binding on the jury or not, the fact remains that many so-called rules for weighing testimony have been laid down by the cours. some of them engrafted with so many "exceptions" that but little of the original principle remains. Thus, it has been held to be a general rule that every presumption is in favor of the credibility of an unmpeached (or unsuccessfully impeached) witness; but it is said the jury should not be instructed as a rule of law to indulge in this presumption; they are to judge of the propriety of so doing in the particular case.

Id. $\S 191$, at 317 .

284. A New York appellate court explained the ruie in terms of the same desire to avoud altnbutıons of perjury that lay behind Bethel's rule:

[The testimony of these two witnesses] is true, or they both commitled willful and comupt perjury. I think the jury... were bound to give credit to their testimony. It was not contradicted .... They were not impeached, or in any way discredited. The positive testumony of an unimpeached, uncontradicted, witness cannot be discredited, or disregarded arbitrarily or capriciously by coun or jury.

Seibert v. Erie Ry., 49 Barb. 583, 586 (N.Y. App. Div. 1867); accord Lankford v. Holion. 187 Ga. 94. 102-03 (1938); Evans v. George, 80 Ill. 51, 53 (1875): Second Nat'l Bank v. Donald. 58 N.W. 269. 269 (Minn. 1894); Lomer v. Meeker, 25 N.Y. 361. 363 (1862); In re Miller's Will. 49 Or. 452.462 (1907): Engmann v. Estate of Immel, 18 N.W. 182, $182-83$ (Wis. 1884); see also Quock Ting v. United Stales, 140 
see in Part V, the rule seems to retain some force today. ${ }^{285}$

\section{B. Empirical Interlude: Criminal Trials in an Eighteenth-Century Court}

Before advancing toward the present, however, I need to answer those who might say that this framework of evidence rules, which exalted the power of the oath and protected juries from the task of resolving competing oaths, floated irrelevantly above the actual goings on in criminal courtrooms. So far, with the exception of Bethel's Case itself and one other case from the same decade, most of my evidence of seventeenth- and eighteenth-century practice has taken the form of commentary by contemporary treatise writers. What if, in actual practice, juries routinely played the role of lie detector?

One answer is that such evidence of actual practice would not ruin our story. During the late seventeenth and eighteenth centuries, a system that had staked its claim to legitimacy in the power of the oath to guarantee truth was slowly giving way to a system that would ground its legitimacy in the liedetecting powers of the jury. During the long transitional period, contrivances like competency rules and Bethel's rule supported the apparent power of the oath to guarantee truth by helping to guard against witness perjury and direct conflicts of oaths, even as the system shifted lie-detecting responsibility to the jury by permitting defense witnesses to testify under oath. If actual judges in actual trials were willy-nilly confronting juries with stark conflicts of oaths and if juries were happily deciding them, the existence of the rules I have been discussing would still betray the system's perceived need, at least in formal expressions of principle, to preserve the oath as a centerpiece of its claim to legitimacy.

But there is no reason to conclude that the system conducted its day-to-day operations inconsistently with its rules. The treatise writers quoted above did not, in the main, view themselves as law makers but as law reporters. That is especially true of Gilbert, who set out the theory of both competency rules and Bethel's rule so powerfully and influentially. ${ }^{286}$ And analysis of the work of London's main criminal court during the eighteenth century confirms that the system operated in greater or lesser degree as its rules might suggest. Case reports of London's Old Bailey show that the power of the oath was palpable and dominant, if not absolute. Moreover, case reports from the end of the century disclose what theory might predict: emerging signs that the jury's formal designation as the system's lie detector was at hand.

U.S. 417, 420 (1891) (stating the rule in more qualified terms); Davis v. Hardy, 8 Gco. 4, Hil., 6 K.B. (Barnwall \& Cresswell) 225, 231 (1827) (Abbott, C.J.).

285. See infra notes 586-589 and accompanying text.

286. See John H. Langbein, Historical Foundations of the Law of Evidence: A View from the Ryder Sources, 96 COLUM. L. REV. 1168, 1173 (1996) ("Gilbert's book was essentially an abridgment-a law-finder that collected precedents."). 
The Old Bailey Sessions Paper ${ }^{287}$ is the best record we have of the operations of an ordinary eighteenth-century trial court, yet it falls far short of perfect. ${ }^{288}$ In the early years of the century, when the Sessions Paper served mainly for popular consumption, it tended toward tabloid reporing, lingering longer than necessary on the sensational and the sexual. By the late eighteenth century, it had taken on both public funding and a public role, often serving as the basis for pardon applications. ${ }^{289}$ The Sessions Paper's greatly increased detail in these later years, ${ }^{290}$ though useful in many ways, complicates comparisons between early-and late-eighteenth-century practice. For example, if we see more defense witnesses toward the end of the century. we cannot be sure whether the difference is real or merely a function of the far greater space given each case. Moreover, the unofficial status of the Sessions Paper early in the century left the reporter free to comment on the merits of the case and the contestants. The late-century "official" reports ${ }^{291}$ sadly omit these quirky but useful asides. The greatest disappointment of the Sessions Paper is the reporter's apparent disinterest in the sort of procedural niceties that concern us now. Both early in the century and late, the reporter left out the arguments of counsel and most instructions of the cour. Evidence rulings fared as badly. As we proceed, I will point out where these gaps in the tape must leave our conclusions uncertain. For now it is safe to assume, as John Langbein has written, that what the Sessions Paper reports probably did happen, but what it omits to mention might have happened too. ${ }^{292}$

Despite such shortcomings, the Sessions Paper tells us a good deal with clarity and gives us the basis for inferring a good deal more. My analysis here will focus on the case reports of 1715 and 1780. By 1715, something less than a generation had elapsed since Parliament's decision to permit sworn defense witnesses. ${ }^{293}$ The court business of that year may therefore tell us something

287. THE PROCEEDINGS OF THE SESSIONS OF THE PEACE, AND OYER AND TERMINER, FOR THE CTTY OF LONDON, \& COUNTY OF MIDDLESEX [hereinafter OBSP]. Following Simon Devereaux, I will call these reports by the contemporary shorthand: "the Sessions Paper." See Simon Devereaux, The City and the Sessions Paper: "Public Justice" in London, 1770-1800, 35 J. BRrT. STud. 466, 467 n.2 (1996). For an analysis of the usefulness and limitations of the Sessions Paper for historians of criminal procedure, see Langbein, supra note 88 , at $267-72$.

Although not the first legal historian to exploit the Sessions Paper. John Langbein seems to have sparked its current celebrity. See id. at 267 n.16; see also Malcolm M. Foeley \& Charles Lester. Legal Complexity and the Transformation of the Criminal Process, in SUBJExTIVIERUNC DES JUSTRZELLEN BEWEISVERFAHRENS 337, 338 (Andre Gouron ed., 1994); Siephan Landsman, The Rise of the Contennous Spirit: Adversary Procedure in Eighteenth Century England, 75 CORNELL L. REv. 497, 509 (1990).

288. See Langbein, supra note 88 , at 269-72.

289. See Devereaux, supra note 287 , at $468-83$.

290. The Sessions Paper of 1715 reported 500-odd cases in just 48 pages of dense newsprint. By 1780 the print had grown larger, but that handly explains the bigger page count: Some 600 cases filled 794 pages.

291. I use the terms "reporter" and "repors" largely for lack of anything better. I do not mean to imply that the Sessions Paper, especially in the early 18 th century, took the carnest and official form of a modem case report.

292. See Langbein, supra note 83 , at 21-26.

293. See supra note 154 and accompanying text. 
about how the system was coping with the new problem of sworn credibility conflicts. The Sessions Paper itself largely dictated my choice of the year 1780 for a late-century comparison. That year was one of just a few during the last quarter of the century in which the Sessions Paper recorded almost every case in some detail. ${ }^{294} \mathrm{My}$ analysis below draws from all 418 cases decided by jury in 1715 and 255 cases-or every other one-decided by jury in $1780 .{ }^{205}$

In both 1715 and 1780, we see clear signs of the great weight of the oath. Let us consider first the very little force carried by the defendant's unsworn word. ${ }^{296}$ In 1715 , a defendant who staked his claim of innocence primarily on his own unsworn denial of guilt had only a marginally greater chance of acquittal $^{297}$ than a defendant who simply sat silent, saying nothing by way of denial or justification ( $26 \%$ versus $23 \%$ ). ${ }^{298}$ In 1780 the defendant's claim of innocence arguably hurt his cause: Those few who sat quietly had a substantially better chance of acquittal than those who rested on their word (42\% versus $32 \%$ percent). ${ }^{299}$ Langbein quotes two Sessions Paper cases

294. Except between 1779 and 1787 and perhaps after 1792, the late-century Sessions Paper reported most cases that ended in acquittal in summary fashion only-reciting the indictment and the result, but omitting the evidence. One reason is that the late-century reports served as the basis for pardon applications, and for that purpose there was of course no need to record the facts behind acquittals. Moreover, city officials worried that publicizing acquittals would encourage crime. See Devereaux, supra note 287 , at 481, 484-86, 491-93 \& n.89, 497 n.103. Former mayor John Wilkes and his democratic disciples are perhaps responsible for restoring reports of acquittals between 1779 and 1787. They apparently believed that publicizing acquittals would reassure the public of even-handed justice. See id. at 484, 491-93.

295. I have counted cases in a somewhat idiosyncratic way to serve my purposes here. If, in a case involving codefendants, the evidence against one defendant varied greatly from that against another, 1 counted the case against each defendant separately. So my total case counts might slightly exceed somcone else's. On the other hand, as this study concerns jury decisionmaking, I have chosen to ignore the rather frequent cases in which the court directed a verdict of not guilty as well as the quite rare cases in which the defendant pled guilty. My case counts therefore exclude these cases. The brevity of some of the 1715 case reports often makes it difficult to tell whether the jury found the defendant not guilty or the judge directed this verdict. Absent good reason to think the jury decided the case, I have excluded it.

296. The Sessions Paper makes clear that the defendant's word was always unsworn. While the crimc victim and other witnesses always "swore" to the defendant's misdeeds, the defendant merely "said" such and such in his defense.

297. Throughout my discussions of the Sessions Paper, I use the expressions "acquittal" and "not guilty" to mean the defendant was fully absolved of guilt. I use the expressions "conviction" and "guilty" to refer to any level of conviction, even one less than that charged in the indictment. In 1715, the jury returned a lesser verdict in $45 \%$ of those cases ending in conviction. By 1780 , for reasons 1 cannot explain, the proportion had fallen to $23 \%$. For 1715 , I can find no interesting correlation between the jury's inclination to reduce the level of the conviction and other criteria reflecting. for example, the strength of the case. Across all categories the proportion of cases in which the jury returned lesser verdicts never fell below $40 \%$ or rose above $53 \%$. In 1780 , however, the jury was decidedly more likely to reduce the level of the conviction in the weakest factual cases. I will report these findings after taking up the distinction between circumstantial and direct cases. See infra notes 320-324 and accompanying text.

298. Both of these comparison groups include some cases in which the defendant called character witnesses. I have excluded cases in which the defendant called fact witnesses because I want to measure the impact of the defendant's unsworn account of events. I should emphasize here what I noted earlicr: Where the reports fail to mention something, we should be cautious in concluding that it did not happen. Especially in these early years, the Sessions Paper often reported so few details of a case that we cannot know for certain whether a defendant did or did not speak-or for that matter, whether she did or did not call witnesses. I am assuming throughout this analysis that silence means something did not happen, although that assumption is almost certainly often wrong.

299. I have caiculated these figures in the manner explained above. See supra notes $295,297-298$. The 
from the late seventeenth century in which the judge focused the jury's attention on the distinction between sworn and unsworn evidence. In one "the Court told the Jury, the Witnesses' Oaths were to outweigh [the defendant's] bare Allegations, and left the Matter to them for the Value." 300 In the other, the reporter wrote that "against the Positive Oaths of two Witnesses, [the defendant's] bare word the Court thought not a sufficient Counter-proof; however they left it to the Jury." 301

The reporter's commentary from the 1715 reports conveys in a subtle way the devalued status of defendants' unsworn statements. In fourteen cases the reporter noted that the defendant's statement was either "not believ'd" (ten times), ${ }^{302}$ not "credible" (twice), ${ }^{303}$ or downright "false" (twice). ${ }^{304}$ Yet only once in all the cases from 1715 did the reporter use any similar term to describe the testimony of a sworn prosecution witness ${ }^{305}$ (or for that matter a sworn defense witness ${ }^{306}$ ). I am not suggesting that the reporter or the jury always believed sworn testimony to be true. Indeed, the reporter often seemed to be winking at his readers about the quality of prosecution testimony: The prosecution was "looking a little odly";,307 it "appear'd very ridiculous"; it was "very base and vexatious" 309 or "unjust"

acquittal rate across all cases was greater in 1780 than in 1715. 35? versus 27\%. Half of this increase was due to the cases arising from the Lord George Gordon nols, which 1 will discuss below. See infra notes 333-344 and accompanying text.

300. Langbein, supra note 88, at 286 (discussing the case of Mary Reed)

301. Id. at 285-86.

302. E.g. John Booze, OBSP. Feb. 23-25, 1715, at 3 ("In his Defence he said but having no Witness, that was not believ'd, and he was found Guilty ...."). In some of these cases the locution was slightly different. See, e.g., Ralph Walker, OBSP. July 13-16. 1715. al 3 ("He sand in his Defence which not being believ'd, he was found Guilty . ..."): John Amold. OBSP. June 2-4. 1715. at + ("He said . . but the Jury did not believe that, and he was found Guslty . . . .).

303. Again, the locution varied. See Edward Dalton. OBSP. July 13-16. 1715. at 1-2 (The Pnsoner in his Defence pretended he did not know [his accomplice] ... [blut the Jury not crediung that Story. found him Guilty ...."); Richard Shepard, OBSP. Apr. 27-30. 1715. at 5 (stating that the defendant's testimony "not being credible, he was found Guilty").

304. Thomas West, OBSP, Dec. 7-10, 1715, at 2 ("The Prisoner denied the Fact, and sasd which being swom to be false, the Jury found him guilty ...."); Daniel Blunt, OBSP. Oct. 12-15, 1715, at 3 ("The Prisoner said he took it from the Ground; but that appeanng to be falsc, he was found Guilty . ")

305. See Thomas Cummins, OBSP, June 2-4, 1715, at 6 (")/The alleged robbery vicum! appear'd to be a very lewd Woman, and had no Credit with the Jury. whereupon the Prisoner was acquilted $"$ )

306. In three cases (not counted above), the reporter's ambiguous language permits the inference that he was commenting on the credibility of a defense witness, though I think the beller reading is that he was referring to the defendant. See Thomas Smout, OBSP. Dec. 7-10. 1715. at 2 ("The Pnsoner denied the Fact. and call'd the other two Soldiers to his Reputation, who gave him a quite contrary Character, but that not being credited, the Jury found him guilty."); William Fraster \& Ann Todd. OBSP. Sept. 7.9. 1715. at 2 ("[The defendants] made a very incredible Defence; and the Witnesses call"d to speak in their Behalf confronting their own Evidence, the Jury found Todd Gulty of Felony: but Frasier was sequitted "). R_R_. OBSP, Jan. 14-17, 1715, at 5 ("In his Defence he endeavour'd to prove he lay at another Place the Night before the Robbery was committed. and did not nse ull 8 of the Clock that Mloming. but that was not believ'd, and he was found Guilty .... .").

307. Mary Wadsworth, OBSP, July 13-16, 1715, at 5.

308. Robert Evans \& William Thompson. OBSP. Feb. 23-25. 1715. at 5

309. Mary Barter, OBSP, July 13-16, 1715, at 5.

310. Elizabeth Newell, OBSP, Oat. 12-15. 1715, at 2.

311. Elizabeth Vincent, OBSP, Feb. 23-25, 1715, at 2 
"trifling"; ${ }^{312}$ or a prosecution witness was "a very litigious troublesome Man. ${ }^{313}$ But with the one exception just noted, the reporter was never so brazen as to call a sworn witness a liar, though he was quite willing to say so of the unsworn defendant. ${ }^{314}$

Perhaps this respect for the oath was feigned, even sarcastic-and perhaps it appeared so to contemporaries-but it may have reflected the system's struggle to cling to the trappings of the old order as a new order loomed. In any event, things perhaps had changed by 1780 . Although the 1780 reports contain almost no reporter commentary, in the one instance of it I saw, the reporter made the kind of attack on a prosecution witness's credibility that never took place in 1715: The witness's testimony, he wrote, "was so prevaricatory and contradictory in itself; and many parts of it being lproved false] by the testimony of a gentleman of character, the prisoner was acquitted, and [the witness] was committed to take his trial for wilful and corrupt perjury. ${ }^{\text {"315 }}$

The reporter's-and jury's-disdain for unsworn statements extended past those of the defendant. When children who were deemed too young to understand the oath spoke without being sworn, the reporter made it plain that their word carried little weight. Hence in one case from 1715: "The Girl said he threw her upon the Bed ... but she not understanding the meaning of an Oath, what she said was not taken as Evidence, and he was acquitted." 316 And in another: " $[B]$ ut there was no Proof of the Prisoner's doing it, but only

312. Edward Macmans, OBSP, June 2-4, 1715, at 5.

313. Edward Gilman, OBSP, Apr. 27-30, 1715, at 6. In all, I counted nine such indirect comments on the credibility of prosecution witnesses. The remaining two are Rebecca David \& Mary David, OBSP, Sept. $7-9,1715$, at 1 , in which the reporter referred to "some malicious Grudges" between some of the prosecution witnesses and the defendants; and William Forest, OBSP, June 2-4, 1715, at 1, in which the reporter referred to the "bad Reputation" of a prosecution witness.

In addition there were nine indirect (though generally more pointed) comments on the credibility of the defendant and one on the credibility of defense witnesses. See, e.g., John Simpson, OBSP, Dec. 7-10, 1715 , at 4 ("The Prisoner said . . . but this Defence not being of any Weight with the Jury, he was found Guilty."); Mary Kutter, OBSP, Oct. 12-15, 1715, at 3 ("The Prisoner said in her Defence . . but that was impossible, it being prov'd [otherwise] .....); Sarah Fairclough, OBSP, Oct. 12-15, 1715, at 1 ("In her Defence she said ... but that being absurd, and the contrary plainly prov'd, she was found Guilty."); Thomas Silver, OBSP, Apr. 11-13, 1715, at 5 ("In his Defence he said ... but that was prov'd altogether groundless, and he was found Guilty ...."). The case involving defense witnesses was Benjamin Payne, OBSP, Oct. 12-15, 1715, at 2, in which the reporter noted that the witnesses had an "indifferent reputation" and were motivated by a bribe.

314. Another indication of the small weight accorded a defendant's unsworn denial in the face of a sworn accusation is how far some defendants went to contrive a claim of innocence that did not contradict prosecution testimony. Two cases from 1715 , both charging burglary, provide good examples. In the case of Thomas Jones, OBSP, Feb. 23-25, 1715, at 2-3, the victim testified that he caught the defendant with his hand on the window sill, apparently on his way in. The defendant "said in his Defence, that he was coming by, and saw the Window open, upon which he went to give Notice to the People, and so put his Hand in, and several Persons appearing to his Reputation, he was acquitted." Id. In the case of Isaac Colt, OBSP, Apr. 27-30, 1715, at 6, the homeowner said he saw the defendant jump out of his window. The defendant "did not deny his being in the House, but said his Fellow prentice threw his Hat in, and he went to fetch it, whereupon he was acquitted." Id.

315. Emanuel Jacobs, OBSP, Dec. 6, 1780 (No. 66), at 50.

316. Daniel Bonnely, OBSP, July $13-16,1715$, at 4 . 
the Child's Word; which not being sufficient to satisfy the Jury, she was acquitted." 317 Langbein reports a case from 1678 in which the jury refused to convict an alleged child rapist until the judge permitted the complainant and her young friend to be sworn. ${ }^{318}$ By 1780 , the court simply excluded statements by witnesses too young to appreciate the oath-and by Quakers, who refused to swear an oath. If the witness's testimony was essential to the prosecution, the court simply directed a verdict of not guilty. ${ }^{319}$

The best way to gauge the power of the oath, however, is not to measure disdain for unsworn evidence, but rather to assess the respect accorded sworn testimony. Here we must distinguish between circumstantial and direct evidence. In circumstantial cases, no witness swears to having seen the defendant commit the crime. Hence the jury may acquit the defendant, not because it disbelieves her accusers, but because it does not think that the facts sworn to by the prosecution's witnesses, even if true, prove the defendant's guilt. ${ }^{320}$ But when a case presents direct evidence of guilt, a jury's verdict of not guilty must normally mean that the jury disbelieves a sworn prosecution witness. During both 1715 and 1780, the Sessions Paper reveals a decided preference for direct over circumstantial evidence and a decided disinclination by juries to reject direct evidence of guilt. The first indication of this preference is that the Sessions Paper, like other contemporary sources, called direct testimony "positive" evidence. The word carried a double meaning that reinforced the value of direct evidence: Eyewitness evidence was "positive" evidence, and an eyewitness who was certain of her identification of the defendant was "positive" of it. ${ }^{321}$ Over and over again, the reporter of the

317. Mary Fadding, OBSP, Feb. 23-25, 1715, at 4

318. See Langbein, supra note 88, at 291-93 (discussing the case of Sicphen Arrowsmuth).

319. See, e.g., William Bailey \& Patrick Madan, OBSP. Dec. 6. 1780 (Nos. S1-52), at 41 (refusing a child witness); Abraham Danford \& William Newton. OBSP. Sepr. 13. 1780 (No. 504). al 704 (refusing the testimony of a Quaker); Mary Madan, OBSP, Feb. 23, 1780 (No. 92). at 129 (direcung a verdict of not guilty after refusing a child witness); John Nixon, OBSP, Jan. 12, 1780 (No. 72), at 95 (refusing two child witnesses). In his 1802 evidence treatise, Leonard MacNally taced the 18th-century evolution of the rule that child witnesses may not give unswom statements. See I LeONard MaCNally. THE RULES OF EVIDENCE ON PLEAS OF THE CROWN 151-54 (London. J. Buttentorth 1802).

As I will point out shortly in another context, see infra notes 327-328 and accompanying text, the testimony of rape victims met with systemic suspicion. It is certainly possible that, in cases of child sexual abuse, the cour expressed its usual distrust of rape victims in tems of the child's pereeived incapacity to swear. It is also true, though, that child witnesses were sometimes rejected in other kinds of crimes. and sometimes their absence resulted in directed verdicts of not guilty. Three cases ciled immediately above are in point: John Nixon was accused of burglary; Mary Madan of theft: and William Balley and Painck Madan of theft from a dwelling house.

320. Most of the circumstantial cases reported in the Sessions Paper concemed theft. In the typtcal case, witnesses would swear that the defendant had been in a position to steal the goods and/or that the defendant later was seen with the goods.

321. A third use of the word-that evidence was "positive" rather than "negaluve"- was mosily a later aberration. Calling Bethel's rule the problem of "positive" (rather than "affirmative") versus "negative" evidence seems to have been rare before the 19th century. See supra notes 21+216, 225 and accompanying text. 
Old Bailey Sessions Paper emphasized the peculiar value of "positive," or direct, evidence. ${ }^{322}$

The numbers seem to bear out the reporter's instincts. In 1715 a defendant who faced a case of pure circumstantial evidence was more than twice as likely to be acquitted than a defendant who confronted a sworn eyewitness (37\% versus $16 \%) .{ }^{323}$ By 1780 , the chance of acquittal in both categories had grown larger (50\% versus $26 \%$ ), but the disparity between them remained almost as great. ${ }^{324}$ These numbers still understate the deference paid to eyewitness evidence. In my 418-case sample from 1715, there were 129 cases that presented direct evidence of guilt. Of these, twenty-one ended in acquittal. Five of these twenty-one cases turned on the testimony of an accomplice. ${ }^{325}$ As the testimony of accomplices was officially disfavored (the uncorroborated testimony of an accomplice seems to have been insufficient to convict), ${ }^{326}$

322. Hence in 1717 , at the trial of George Marshall for pickpocketing, the victim said that "the Prisoner cut her Pocket; that she feeling some body have hold of it, catch'd hold of the Prisoner, there being no other Person there." George Marshall, OBSP, Oct. 16-17, 1717, at 1 . The reporter then noted, "The Prisoner denied the Fact, and said there were other Persons there besides himself; however this did not avail him. The Evidences being positive, the Jury found him Guilty of the Indictment." Id. (cmphasis added); see also, e.g., Mary Sutron, OBSP, Apr. 8-11, 1719, at 5 ("The Prisoner denied the Fact, but the Evidence being very full and positive, the Jury found her Guilty . . ..").

Conversely, in a case from 1715 , the reporter was careful to note that the evidence had been merely "presumptuous"-a variant of "presumptive," the term usually used to denote circumstantial evidence: "The Fact was prov'd very presumptuous on the Prisoner; but the Evidence not being positive; some Persons whom she call'd to her Reputation, giving her a good Character; and that she got an honest Livelihood, she was acquitted." Jane Thomas, OBSP, Oct. 12-15, 1715, at 2 (emphasis added).

323. By a "pure circumstantial case," I mean one in which there was no evidence of a confession by the defendant. Adding the defendant's confession to a circumstantial case made a considerable difference. In 1715 , it reduced the likelihood of acquittal from $37 \%$ to $5 \%$. In 1780 , it reduced the likelihood from $50 \%$ to $20 \%$. That defendants who confessed were so much more likely to be acquitted in 1780 than in 1715 is probably due to increased institutional suspicion focused on the manner of obtaining confessions. In 1780, the court refused to admit evidence of confessions obtained by threat or promise of favor. Sce, e.g., Thomas Collins et al., OBSP, Oct. 18, 1780 (Nos. 609-11), at 791 (excluding any statement of the defendant made after a promise of reward); William Goodchild, OBSP, June 28, 1780 (No. 409), at 602 (similar); Edward Gandy, OBSP, Apr. 5, 1780 (No. 198), at 260 (apparently directing a verdict of not guilty because there was no evidence except the defendant's confession, "which had been improperly obtained"); see also Langbein, supra note 83, at 103-05 (discussing the development of the "confession rulc," which excluded evidence of confessions given under threats or promises).

324. Another index, perhaps, of the greater certainty provided by positive evidence is that judges in direct evidence cases were a good deal more likely to impose a death sentence in the event of a conviction than were judges in pure circumstantial cases. They did so in $31 \%$ of direct-evidence cases versus $21 \%$ of pure circumstantial cases in 1715 and in $36 \%$ of direct-evidence cases versus $17 \%$ of pure circumstantial cases in 1780 . Juries were less consistent in responding to this distinction. In 1715, juries reduced the level of the conviction in $43 \%$ of direct evidence cases and $40 \%$ of pure circumstantial cases-a liny difference and in the opposite direction from what one might expect. In 1780, the jury responded more as we might expect, returning a lesser verdict in $33 \%$ of pure circumstantial cases but in only $17 \%$ of direct evidence cases.

325. See Thomas Salter \& Elizabeth Salter, OBSP, Dec. 7-10, 1715, at 5; William Forest, OBSP, Junc 2-4, 1715, at 1; John Tent, OBSP, Feb. 23-25, 1715, at 2; Henry Hill, OBSP, Jan. 14-15, 1715, at 2; Evan Roberts, OBSP, Jan. 14-15, 1715, at 2.

326. Langbein writes that the rule requiring corroboration of an accomplice's testimony was wellestablished by the middle of the 18th century. See Langbein, supra note 83, at 98-103. The Sessions Paper of 1714 and 1715 suggests the rule was already in place, though the language leaves room for a different interpretation: that juries were merely reluctant to convict on an accomplice's uncorroborated testimony. See, e.g., Matthew Cornwall, OBSP, Apr. 27-30, 1715, at 3 ("[B]ut there being no other Evidence against 
the jury that decided these cases did not buck the general presumption in favor of sworn evidence. Three other cases rested on the testimony of a rape victim, ${ }^{327}$ and just as the system formally devalued the testimony of criminal accomplices, so it did the testimony of rape victims. ${ }^{328}$ One case relied on the testimony of an unsworn child, ${ }^{329}$ yet another disfavored form of evidence. In six of the remaining twelve cases, the facts permitted the jury to judge the prosecution's witnesses truthful and yet maintain doubts about the defendant's guilt. ${ }^{330}$ That leaves only six of the 129 direct-evidence cases

the Prisoner ... than the bare Oath of [the accomplice], he was acquitted . . "). Henry Hill, OBSP, Jan. 14-17, 1715, at 2 ("But there being no Witness against hum but (the accomplice). and having a great many People to his Reputation, he was acquitted."): William Hoshıns. OBSP. Dec 8-14, 17/4, at 4 ("But there being no other Evidence but [the accomplice]. to prove the Pnsoner [was] concern'd [in the crime], he was acquitted."). But see, e.g., James Lewis, OBSP, July 13-16. 1715. at 5 (repontung a conviction based on accomplice testimony without mentioning corroboration). By late in the century, the Sessions Paper made clear that corroboration was required and that lach of corroboration would entule the defendant to a direeted verdict. See, e.g., James Whitehouse et al., OBSP, May 18-21. 23. 177.4 (Nos. 396-99). at 219 ("Cour. As there is no evidence against Piner besides the accomplice. I shall not put him upon his defence "): Willam Rice et al., OBSP, Apr. 13-16, 18-20, 1774 (Nos. 262-64), at 167 ("Cuurt. As there is no evidence against Perrier but that of the accomplice, I shall not call upon hım for his defence ").

In England the accomplice corroboration rule died in 1788 as a result of Rex $v$ Arwood \& Robbins. 168 Eng. Rep. 334 (1788), which held that as an accomplice is a comperent witness, it is for the jury "to say whether they think [his testimony] sufficiently credible to guide their decision on the case " 168 Eng. Rep. at 335 (emphasis added); see also Langbein. supra note 83. al 102-03 (discussing the signiticance of Arwood \& Robbins). In the United States, as we will see in Pan V. the rule has proved to have greater staying power. See infra notes 590-595 and accompanying Iext. The rule has obvious relevance to this study, as it is one more intrusion on the jury's lie-deiecting discretion In a sense. the requirement of corroboration operates as a less absolute competency rule.

327. See William Willis, OBSP, Dec. 7-10, 1715, at 5: M_ K_. OBSP. Od 12-15, 1715. at 5: William Cash, OBSP, July 13-16, 1715, at 5.

328. The Sessions Paper provides other evidence of the dimınıshed status of rape complaınanis as witnesses. As I will discuss below when I return to the issue of Bethel's rule, the Sessions Paper of 1715 reports only two instances in which the defendant put forth negauve testumony in the face of affimalive prosecution testimony -and both of these are questionable examples. See infra note 341 and accompanying text. In other years of the same period, however. I found iwo clear examples, and both concerned rape See Isaac Seaman, OBSP, May 14-16, 1719, at 7 (reporting that "the Prisoner's Sister-In-Luw deposed that she heard nothing ..." and that another witness specifically denied an event to which the victum had testified); Richard Nevill, OBSP. Apr. 11-13,1716. at 5 (statung that the prisoner "brought several Persons to prove there was no Noise"). One can surmise that some rape defendants thought the usual rule-ihat negative evidence is powerless in the face of swom affirmative evidence-did nol apply when the affirmative evidence is that of a rape complainant. See J.M. BEATtIE, CRIME AND THE COL RTS IN ENGLAND 1660-1800, at 124-32 (1986) (discussing the institutional obstacles and suspicions encountered by rape victims).

329. See Mary Fadding, OBSP, Feb. 23-25, 1715, at 4.

330. In three of these cases the defendant conceded the objecuve facts, but denied the crime. See Thomas Cooke, OBSP, Dec. 7-10, 1715, at 2 (reporting that the defendant, who was aceused of embezzling from his employer, admitted he made unauthonzed charges aganst the employer's account, but sand he did so to cover the employer's own debts): Isaac Colt. OBSP, Apr. 27-30. 1715. a1 6, discussed supra note 314. Thomas Jones, OBSP, Feb. 23-25, 1715, at 2-3, discussed supra at note 314 . In a founth case. the objective facts apparently were not disputed, but proved insufficient to convict. See Henn Whitc, OBSP. Dec 7-10. 1715 , at 3 (noting in a murder case that "it not being belseved that that One Blow occaston"d his Death, the Jury acquitted the Prisoner"). The fifth and sixth cases presented questions of identity. and the jury may have believed the prosecution's witnesses were honestly mistahen See Richard Robinson. OBSP, Apr 27. 30,1715 , at 4 ("[N]or could the Prosecutor be positive [the defendani] was the Person who took it, whereupon he was acquitted."); William Downer. OBSP. Feb. 23-25. 1715. at 4 (reporting that the defendant, who was seized on the street after a shopkeeper ened thief. "deny'd he was ever in the Shop. but [said] he was going by that way, and [was] taken by Mistake. and the Person who took him [tesufied 
from 1715 in which the records permit us to conclude that the jury acquitted the defendant because it rejected the sworn testimony of a prosecution witness whom the system otherwise deemed credible. ${ }^{331}$

The Sessions Paper of 1780 tells a more complicated story. In that year, a somewhat smaller sample of 116 direct-evidence cases yields fully seventeen in which the jury appears to have rejected as untruthful the sworn evidence of a prosecution witness who was neither an accomplice nor a rape victim. ${ }^{332}$ Whether this large number means that juries had grown more willing to reject sworn testimony depends in part on the significance of this additional fact: Of these seventeen anomalous cases, eleven arose out of the Lord George Gordon riots that shook London in early June $1780 .{ }^{333}$ The depredations of the

that the defendant] did not run, but was walking a very gentle pace, and [that although the defendant was] immediately search'd, nothing was found upon him").

331. In two of these, the jury apparently chose to credit the defendant's unsworn denial over the prosecution's swom accusation. The two cases bear a certain similarity, in that the alleged victim had been in the company of the defendants and they were perhaps drinking together before the crime. In the case of Eleanor Turner \& Elizabeth Wells, OBSP, July 13-16, 1715, at 4, the victim claimed that the two defendants, together with two unidentified men, robbed him. One of the defendants said in her defensc:

[The victim] was in drink, and came into her House with a Woman of her acquaintance,

where she left them together, and went out; and when she came in again found them in Bed, at which being much surpriz'd, she made them get up, and he went away without complaining of any loss.

Id. In the case of James Ayres, OBSP, Sept. 7-9, 1715, at 4, the victim testified that he and the defendant had been "going the same Way together ... and they drank together" before the defendant robbed him. The defendant admitted to having been with the victim, but denied the robbery. I have noted often in reading the Sessions Paper that, as these cases suggest, juries seem to have devalued prosecution tcstimony when the witness had been drinking at the time of the events. The defense that the victim was seeking or having sex at the time of the crime was often made and sometimes successful.

In two other cases, the jury apparently chose to believe the testimony of the defendant's witnesses over direct testimony by a prosecution witness. See Elizabeth Mossly, OBSP, Oct. 12-15, 1715, at 2 (reporting in a perjury prosecution that witnesses disputed what the defendant said in her allegedly perjured testimony); John Overloin, OBSP, Apr. 27-30, 1715, at 4 (reporting that the defendant presented a witness who said that the defendant was elsewhere at the time of the crime). The latter case might also have been one of mistaken identity.

In the final two cases, the reporter's comments leave the strong impression that there was something amiss with the prosecution witnesses' credibility. See Edward Gilman, OBSP, Apr. 27-30, 1715, at 6 (noting that the only eyewitness to the crime was "a very litigious troublesome Man"); John Tisden, OBSP, Apr. 27-30, 1715, at 4 ("[The prosecutor's] Evidence being very imperfect, the Prisoner was acquitted.").

332. Thirty of the 116 direct-evidence cases ended in acquittal. Three of these relied on the testimony of an accomplice or rape victim. See Christopher Morris et al., OBSP, Oct. 18, 1780 (Nos. 603-05), at 778; George Weaver, OBSP, Sept. 13, 1780 (No. 519), at 717; William Bennett et al., OBSP, Apr. 5, 1780 (Nos. 163-65), at 208-09. Ten presented the possibility of mistaken identity. See Charles Allen \& Josiah Larcher, OBSP, Oct. 18, 1780 (Nos. 594-95), at 771; Robert Downing \& William Wood, OBSP, Sept. 13, 1780 (Nos. 510-11), at 710; William Harding, OBSP, Sept. 13, 1780 (No. 448), at 648; James Watts, OBSP, June 28, 1780 (No. 379), at 544; James Coulsell, OBSP, June 28, 1780 (No. 356), at 502; Richard Wilson, OBSP, June 28, 1780 (No. 342), at 476; Frances Lawley, OBSP, June 28, 1780 (No. 340), at 472; Levy Abrahams, OBSP, May 10, 1780 (No. 287), at 342; George Cook, OBSP, May 10, 1780 (No. 259), at 322; Thomas Phillips, OBSP, May 10, 1780 (No. 226), at 288.

333. Of the six remaining cases, one can be explained by the near worthlessness of the goods stolen. See Thomas Cullen, OBSP, Jan. 12, 1780, at 81 (proving the theft of goods valued at nine pence or less). In a second, the complainant alleged that two women, apparently prostitutes, had stolen his watch-the kind of claim to which juries were typically unsympathetic, if not necessarily disbelieving. See Lucy Hambleton \& Martha Raymond, OBSP, May 10, 1780 (Nos. 281-82), at 338. A third case involved an alleged theft by two journeymen textile workers. See Thomas Richardson \& William Dowdey, OBSP, May 10, 1780 (Nos. 278-79), at 337. Understanding this case requires a better grasp of the industries of the day than 1 
anti-Catholic mob, which burned or raided three prisons and destroyed the homes of many prominent citizens, generated a huge traffic of cases $^{334}$-accounting for thirty-five of the 255 cases I sampled from 1780. An extraordinary acquittal rate of $57 \%$ does not quite capture the suspicion with which juries greeted these prosecutions. At first, still in the shadow of the riots, juries stood ready to convict. Nine of the first eleven cases ended in guilty verdicts, and in eight of these the court sentenced the defendants to die. $^{335}$ Juries then acquitted in three-quarters of the remaining twenty-four cases.

Although it is likely that juries grew disaffected with these prosecutions as death sentences mounted and the riots receded from memory, such a change of heart cannot entirely explain the great number of acquittals. And indeed, the riot trials themselves were different from typical trials of the day. An unusual number of defendants had counsel, and those counsel had an unusually potent line of cross-examination-the fifty-pound reward the King had offered to anybody who won the conviction of a rioter. ${ }^{336}$ It is not that such substantial rewards were new. Since 1692, the government had paid forty pounds for the capture and prosecution of a highway robber. ${ }^{337}$ and in the years after, high-profile scandals had alerted everyone to the possibility of perjury by professional thief-takers. ${ }^{338}$ In several cases from 1780 not related to the riots, defendants had insinuated that the promise of reward motivated prosecution testimony. ${ }^{339}$ But the riot cases presented a new twist on the familiar prospect of prosecutions grounded in greed. The crimes were public, so any one of dozens of people could plausibly claim to have witnessed them. Yet the person we would most expect to lodge charges and claim a

have. In the last three cases, the jury seems to have chosen to disbelieve storn prosecution testumuny See Isaac Abrahams, OBSP, Dec. 6, I780 (No. 49), at 40: John Banley. OBSP. Sept 13. 1780 (No 40), at 644; Thomas Mabett, OBSP, Jan. 12, 1780 (No. 53), at 77.

334. According to one source, there were 192 convictions and 25 executions. Ser 8 Dictiovary OF NATIONAL BIOGRAPHY, supra note 123, at 197-98. Gordon. who was president of the Protestant Association, was tried for high treason in February 1781. He was acquitted for want of evidence that he had incited the mob. One measure of the magnitude of the nots is that 300 noters were billed when the army came to take control. See id.

335. In the end, the sentences of several of these defendants were "resplted dunng his Majesty's pleasure." OBSP, June 28, 1780, at 640 .

336. See, e.g., Thomas Downs, OBSP. June 28, 1780 (No, 407). ar 598-99

337. See An Act for Encouraging the Apprehending of Highwaymen. 4 W \& M.. ch 8 (1692) Despite the usual rule against testimony by persons with a financial interest in the case. the promise of a reward did not exclude prosecution witnesses in cnminal cases. See $R \vee$ Newland, I Leach 311,314 n a (K.B. 1784) (citing this holding in a Gordon riots case).

338. See Langbein, supra note 83, at 106-14.

339. See Abraham Danford \& William Newton. OBSP. Sept 13. 1780 (No 504), al 704. Thomas Carter \& Mary Evans. OBSP. May 10, 1780 (Nos. 267-68), at 332. Chnslopher Burrows \& John Burden. OBSP, Feb. 23, 1780 (Nos. 123-24), at 167: John Benfield \& Willam Turiey, OBSP, Jan 12, 1780 (Nos 80-81), at 107; see also J.M. Beatie, Scales of Jusfice: Defense Counsel and the English Crmunal Trat in the Eighteenth and Nineteenth Centuries. 9 LAW \& HIST REV. 221. 239-4 (1991) (presentung examples of noted defense counsel William Garrow's unterrogation of ultnesses about, among other things. thetr hopes of reward). 
reward-the owner of the home torn down-was often not present, having fled from the mob. As a result, random onlookers frequently brought charges, heightening the potential for financial opportunism. Defense counsel pursued as well another line of attack on the truthfulness of prosecution witnesses. The riot cases provide the only examples I have seen in the Sessions Paper of counsel calling witnesses to testify about a prosecution witness's bad character for credibility. In these cases, we see the spectacle of a defense witness testifying, "Upon my oath, I would not believe him upon his oath."340

The riot cases also stand out in the frequency with which defense witnesses denied seeing or hearing facts to which prosecution witnesses had testified. By the principle of Bethel's rule, such negative evidence should have been powerless in the face of affirmative prosecution testimony. And indeed, in 1715 negative evidence was extremely rare: It appeared in only two of 418 cases, and both of these are questionable examples. ${ }^{341}$ Yet in 1780, my 255-case sample turned up nine such cases. It is true that in four of these the jury convicted the defendant-so for all we know, the jury heeded the admonition of Bethel's rule and valued affirmative evidence over negative. ${ }^{342}$

340. Henry John Maskall, OBSP, June 28, 1780 (No. 301), at 399; see also Gcorge Simpson, OBSP, June 28, 1780 (No. 405), at 593 (similarly discrediting a witness); Stephen Titcombe, OBSP, June 28, 1780 (No. 319), at 434 (similar). The form of question-inquiring whether one witness would believe another under oath-was not new, see 7 WIGMORE, supra note $44, \S 1982$, at $148,150 \mathrm{nn} .7-8$, but to judge from the Sessions Paper, it was quite rare.

341. In one, a murder case, a defense witness swore that "he did not see any Wound given." Richard Marriot et al., OBSP, June $2-4,1715$, at 4 . But as the prosecution had proved the wounding through circumstantial evidence (no prosecution witness testified to seeing the wound inficted), the defendant's negative evidence did not actually oppose affirmative prosecution evidence.

In the second case, which charged seditious words, two prosecution witnesses swore they heard the defendant's drunken barroom bawl, "God damn King George, he has no Right to the Crown." Willian Wide, OBSP, Feb. 23-25, 1715, at 1. Against this evidence, the defendant called "several Witnesses who swore, That they had known, and convers'd with [the defendant] a great while, and never heard him say any Thing against the Government." Id. Far from violating Bethel's rule, the defendant in this case scems to have steered clear of it: He produced no witness to deny the specific speech alleged by the prosecution.

In two other cases of seditious words from 1715 , the defendants called witnesses who were present at the scene, yet those witnesses conspicuously failed to deny that the defendants had spoken the offending words. In the first, a prosecution witness "positively swor[e]" to the defendant's outburst against King George, spoken in a crowded tavern. Lewis Amand de la Cour, OBSP, Feb. 23-25, 1715, at 5. Although one of the defendant's witnesses said that "while he was there, the Prisoner as readily as the rest, drank the King's Health by the Name of King George," none of his witnesses denied hearing the seditious words. Id. In the second case, a prosecution witness swore that the defendant "drew his Bayonet with great Passion," crying "G-d d-n King G__e." Thomas Smout, OBSP, Dec. 7-10, 1715, at 2. The defendant called two soldiers who were with him at the time of the events, who testified to his character but said nothing of the facts.

The failure of the defendants' witnesses in these cases to say the accused never spoke ill of the King suggests that Bethel's rule may have exerted a quiet negative force: As affirmative evidence trumped negative, once the prosecution had made out an affirmative case, defendants did not bother to offer negative evidence.

342. See Charles West et al., OBSP, Sept. 13, 1780 (Nos. 499-501), at 697-98 (reporting a counterfeiting case in which witnesses denied the existence of a passageway to a hidden chamber); John Harris, OBSP, Sept. 13, 1780 (No. 464), at 669 (reporting a theft case in which a witness denied secing. the defendant throw a watch over a wall); Thomas Price et al., OBSP, June 28, 1780 (Nos. 420-22), at 623 (reporting a riot case in which a witness denied seeing the defendant at the scene); James Purse, OBSP. May 10,1780 (No. 289), at 352-53 (reporting a rape case in which witnesses denied hearing a rape or 
In the five remaining cases, however, the jury acquitted, and all of these were riot cases. ${ }^{343}$ Although we can only guess at what motivated these juries to acquit, it is hard to escape the conclusion that they chose to credit the negative evidence of the defendants' witnesses because they disbelieved the affirmative allegations of the prosecution's witnesses. That is, they made exactly the sort of attribution of perjury that Bethel's rule attempted to avoid. In any event, the phenomenon does not seem to have spread beyond the riot cases: In the exceedingly common cases of theft that accounted for most of the rest of the court's docket, we see but a single, unsuccessful attempt to oppose affirmative evidence with negative. ${ }^{344}$ Perhaps, then, the riot cases must stand as isolated harbingers of change.

The Sessions Paper of 1780 reveals one other sign of change-a sign not limited to the riot cases. In 1715 , only $7 \%$ of case reports mentioned defense witnesses other than character witnesses or the defendant herself. By 1780 , that number had more than doubled to $18 \%$. We may read this increase as evidence of a greater willingness of defendants to challenge sworn evidence and of juries to take such challenges seriously-but we should not exaggerate the change. For one thing, the difference may merely reflect the increasing detail of the Sessions Paper's case reports rather than any real difference in the courtroom. Moreover, without the riot cases, the increase in defense witnesses would have been halved-to $13 \%$. That number is more in line with Malcolm Feeley and Charles Lester's much larger survey of the Sessions Paper, which found that the proportion of defendants who called witnesses to dispute the government's evidence hovered at around $10 \%$ for another full century. ${ }^{345}$

seeing blood). In the Charles West case, the witnesses were encouraged to say that they had spectically looked for a secret passageway that they now said did not exist - so their testimony took an almost posilive form: "I can say positively there was not" such a passageway. one sald. Charles West et al. OBSP. Sept. 13, 1780 (Nos. 499-501), at 697.

Unfortunately, as the reporter has given us neither lawyers' arguments nor judge's charge, ue cannot know if either cited Bethel's rule.

343. In all of them the negative evidence took the form of an assertion that the witness did not see the defendant at the riot or did not see him misbehaving. See Luke Hand. OBSP. June 28. 1780 (No. 424 ). at 629-31; John Barrett, OBSP, June 28, 1780 (No. 392). at 564; David Wilson. OBSP. June 28, 1780 (No. 384), at 554; James Coulsell, OBSP, June 28, 1780 (No. 356), at 504; Henry John Maskall, OBSP. June 28, 1780 (No. 301), at 393-98.

344. See John Harris, OBSP, Sept. 13, 1780 (No. 464), at 669

345. See Feeley \& Lester, supra note 287, at 361.363. My figures give uneven suppon to another conclusion of Feeley and Lester. They argue that the inal process of the 18 ith century "was in faet more of a sentence hearing than a guilt-determining process." Id. at 361. That is, the point of tnal was not to discover the fact of the defendant's guilt, but to decide what punishment the defendant deserved. See id.: see also Langbein, supra note 83 , at 41,55 (stating that the main function of many 18 th-century cnminal trials was to make sentencing decisions). Because facts were not much at issue, tnals were quite short: Untıl the mid-19th century, the average judge at the Old Bailey presided over at least two and as many as almost five jury trials in a day. See Feeley \& Lester, supra note 287, at 351-52. And instead of relying on fact witnesses, defendants often called witnesses to speak to their good character. Feeley and Lester's figures indeed show that mid-and late-18th-century defendants called character witnesses in over 30\% of all cases. See id. at 363.

My findings are more ambiguous. In 1715. only 119 of defendants called eharacier witnesses. Those 11\%, however, profited for their efforts: Defendants who called character wilnesses (but nol fact witnesses) 
And even if we take the larger number, it means that in only $18 \%$ of cases was the defendant in any position to turn the trial into a credibility contest between sworn witnesses. Yet we should not minimize the change either. More defense witnesses meant the potential for more sworn credibility conflicts-the thing the system had strived so long to prevent. ${ }^{346}$

\section{Alibis and the Problem of Unavoidable Conflicts}

So far, I have discussed the ways in which the criminal justice system attempted to avoid the spectacle of conflicting oaths at trial. The early rule forbidding sworn defense witnesses and later rules forbidding testimony by persons with strong incentives to lie pursued this goal in a direct, even brutish fashion. Bethel's rule sought to avoid credibility conflicts more subtly, in effect encouraging juries to presume that one witness was mistaken before concluding that either witness had lied. The related rule that juries may not disbelieve the uncontradicted, unimpeached testimony of a disinterested witness expressed in its most straightforward form the system's commitment to the presumption that all sworn testimony was true.

But all sworn evidence was not true, and the system had to confront this reality rather often. In this section I will examine the problem of alibis. Alibi defenses insured that once the system permitted sworn defense witnesses it could never altogether avoid the spectacle of head-to-head credibility conflicts. The system's apparent embarrassment at the problem of alibis and its sometimes stilted and formulaic way of resolving alibi claims and other credibility conflicts reinforce the image of a justice system deeply uncomfortable with the idea of juries' choosing between competing oaths.

Bethel's rule, as I noted earlier, had the power to avoid credibility conflicts only when the witness who testified negatively might plausibly have been

were almost twice as likely to be acquitted than the average defendant ( $53 \%$ versus $27 \%$ ). Although by 1780 the proportion of defendants who called character witnesses had increased to $34 \%$, juries apparently had ceased to listen. Defendants who called character witnesses (but not fact witnesses) were acquitted $39 \%$ of the time, barely exceeding the average for all defendants of $35 \%$.

In both 1715 and 1780 , defendants who called fact witnesses substantially increased their chances of acquittal as against the average defendant: $57 \%$ versus $27 \%$ in 1715 and $54 \%$ versus $35 \%$ in 1780 .

346. One other, more ambiguous development in 1780 is worth noting. In 20 of the 255 cases sampled, the defendant asked the court to sequester the prosecution's witnesses. The point of sequestration is to keep one witness from hearing another testify, thereby frustrating attempts to coordinate stories and enabling opposing counsel to expose inconsistencies. The 1715 Sessions Paper mentions no such request. It is true that the tactic of sequestering witnesses has been known at least since Fortescue mentioned it in his 15 th-century treatise, see FORTESCUE, supra note 52, at 61 (describing the sequestration procedure in civil cases), and Wigmore cited several 16th-, 17th-, and 18th-century sequestration requests, see 6 WIGMORE, supra note $44, \S 1837$, at 349 n.10. It is also true that sequestration is often a tactic not to expose liars, but simply to keep witnesses whose memories of the criminal's face are fading from reinforcing one another. See, e.g., Thomas Williams, OBSP, Apr. 5, 1780 (No. 173), at 220 (reporting a sequestration request by a defendant who presented a claim of mistaken identity). Still, it is hard not to spy in so substantial a change a creeping modernity. By 1780, many lawyers and defendants apparently had embraced one very important tool to facilitate jury lie detecting. 
mistaken. The testimony of Bethel's witnesses that they never saw him strike the King's servant is just the kind of negative evidence to which the rule was best suited-for the witnesses may have been looking elsewhere at the moment of the crime. In contrast, a defense alibi witness who swears that the defendant was with her at the time of the crime cannot easily be mistaken. As Thomas Starkie made clear, Bethel's rule was powerless to avoid the conflict of oaths raised by an alibi defense:

[T] his principle [of Bethel's rule] is inapplicable where a negative depends on the establishment of an opposite positive fact. Thus an alibi negatives the actual commission of a crime by the prisoner, but the evidence is of as direct and positive a nature as that which tends to prove his presence and actual commission of the crime. ${ }^{3.7}$

An alibi defense confronts a jury squarely with what Bethel's rule strived to avoid-the task of choosing between competing oaths.

James Fitzjames Stephen, who understood better than many historians the system's aversion to conflicting oaths, saw the difficulty alibis posed. He reported that in Scotland, which seems to have borrowed elements of both Roman law and common law, Sir George Mackenzie had suggested in the late seventeenth century that judges review proposed alibi defenses ahead of trial and simply bar prosecution of any defendant whose alibi is clearly proved-"for to admit contrary Probations, were to open a Door to Perjury. ${ }^{348}$ Here we see shades of the Act To Abolish Hostilities of $1607,{ }^{349}$ which sought to avoid conflicts of oaths by allowing the jury to screen witnesses before they were sworn. Mackenzie's "strange rule," Stephen said, survived in Scotland until $1735 .{ }^{350}$ In England, however, no such procedure removed alibi cases from the courts. Although it is possible that magistrates refused to issue charges whenever defendants came forward with convincing alibis, an increasing number of alibi cases found their way into the

347. I STARKIE, supra note 233, § LXXXII, at *518-19. In his Commentanes on the Law of Scolland. David Hume quoted an unidentified author who spelled out the difference between disallowed negative evidence and an affimnative alibi:

A defence contrary to the [accusation] may be sustained, if it resolve in a posituve proposition. A [defendant] indicted for committing a crime at a certain place. cannol be allowed to bring witnesses to prove in general that proposition, that he was not there. But if he limit his proposition by offering to prove, that at the time [alleged]. he was alibi, though that proposition is contrary to the [accusation], every day's practice allows it relevant to be proven.

2 HUME, supra note 102, at $74 \mathrm{n} .1$. This proposition seems inconsistent with Mackenzic's rule discussed just below in the text. It is possible that this passage was contemporary with Hume, who wrote in 1790. whereas Mackenzie wrote in the late 17th century.

348. MACKENZIE, supra note 66, at 241-42, discussed in I STEPHEN, supra nole 28, at 353.

349. 4 Jam., ch. 1 (1607); see supra Section II.B.

350. I STEPHEN, supra note 28, at 353. Stephen appears to be relying here upon Hume, who wrote that Mackenzie's rule "had really been observed in some instances" and suggested that no prosecutor admitted the propriety of conflicting oaths until 1735. 2 HUME, supra note 102, at 75,77 . 
courtroom. In seven of the 418 cases I studied from 1715 and in twenty-six of the 255 cases I studied from 1780, the defendant presented alibi defenses. ${ }^{351}$

The important question, for our purposes, is how the system advised juries to resolve the credibility conflicts posed by alibi defenses. Gilbert undertook to explain how juries should resolve competing oaths in his early-eighteenthcentury evidence treatise. His first rule was that the jury should, if possible, reconcile the two oaths by preferring affirmative evidence over negative-this was the principle of Bethel's rule. ${ }^{352}$ "[B]ut where the Affirmative and Negative oppose each other in contradictory Propositions," as in the case of alibi, then Gilbert proposed other rules for resolution of the conflict. ${ }^{353}$ The first of these reads, "If there be two Witnesses against two, and no Preponderating as to their Number, they are to be weighed as to their Credit." ${ }^{354}$ Gilbert perhaps thought it needless to say that if one side had a greater number of witnesses, that side should prevail.

The notion that numerology can help settle credibility conflicts is now quite dead, ${ }^{355}$ but it survived well into the nineteenth century. Best's treatise of 1849 presented the problem of alibis in this intriguing light:

In many cases . . . the tribunal is compelled to decide on the relative credit of witnesses who swear in direct contradiction of each other. Where, for instance, a murder or larceny is proved by one or two witnesses, and an alibi or other defence wholly irreconcilable with their evidence, and inconsistent with any hypothesis of mistake, is

351. Not all of these cases involved direct conflicts of oaths. In some, the defendant's own unsworn statement included a claim of alibi, but was unsupported by sworn witnesses. In others, the prosecution's case was purely circumstantial and included no sworn testimony that the defendant was at the crime scene.

352. GILBERT, supra note 70, at 157.

353. Id.

354. Id.

355. In the Fifth Circuit, jurors are told bluntly, "[D]o not make any decisions simply because there were more witnesses on one side than on the other." FIFTH CIRCUIT CRIMINAL JURY INSTRUCTIONS $\$ 1.09$ (1990). Other jurisdictions have similar rules. See, e.g., CALIFORNIA JURY INSTRUCTIONS, CRIMINAL $\$ 2.22$ (West 1993) ("You are not bound to decide an issue of fact in accordance with the testimony of a number of witnesses, which does not convince you, as against the testimony of a lesser number or other evidence, which appeals to your mind with more convincing force."); People v. Pugh, 436 N.E.2d 737, 743.44 (III. App. Ct. 1982) (disapproving of a judge's instruction that in "deciding whether any fact has been proved, it is proper to consider the number of witnesses testifying on one side or the other" even though the judge also said that "the number of witnesses alone is not conclusive if the testimony of the lesser number is more convincing"); People v. Bender, 335 N.W.2d 85, 87 (Mich. Ct. App. 1983) ("Under Michigan law, the number of witnesses which a party produces at trial is quite irrelevant in determining where the truth lies.").

One can find only very few, somewhat half-hearted appeals to the numerology principle. See, e.g., White v. State, 410 So. 2d 135, 137 (Ala. Crim. App. 1981) (approving the trial judge's refusal to instruct that "the weight of the evidence is not necessarily determined by the number of witnesses testifying on either side," and commenting that "disparity in the number of witnesses is a circumstance not to be overlooked"); State v. Coburn, 165 A.2d 349, 354 (Vt. 1960) ("[T] he truth is not established by the relative strength in the number of witnesses on one side against the other. The jury is at liberty to accept the word of the minority .... [But if] the jury should regard the witnesses to be worthy of belief, the numerical strength might control."). An occasional instruction advises the jury to consider whether witness testimony is corroborated by the testimony of other witnesses-arguably creating a preference for the greater number. See, e.g., State v. May, 121 N.W.2d 564, 564 (Neb. 1963). 
proved by a like number called by the accused, the verdict of the jury virtually, although not formally, determines that one set of witnesses or the other has committed perjury. ${ }^{356}$

Best was not attempting here to prescribe how a jury should resolve alibi cases. He was making the modern observation that juries do in fact engage in lie detecting. He suggested they do so, however, only as a last resort-only when "compelled." The jury's first step is to try to reconcile an alibi defense with the accusation, perhaps by attributing the conflict to someone's "mistake"-an application of Bethel's rule. The second step is to appeal to numerology and count each side's witnesses. Only if the stories are "irreconcilable," "inconsistent with any hypothesis of mistake," and "proved by a like number" will a jury be "compelled to decide on the relative credit of witnesses"- and perhaps to "determine[] that one set of witnesses or the other has committed perjury."

Although I have been focusing until now on alibi defenses, the treatises did not restrict numerological principles to that context. Almost every major treatise suggested that whenever jurors faced the task of choosing between conflicting oaths, they should tend to give more credit to the side that produced the greater number of witnesses. That is true not only of the eighteenth-century treatises-Gilbert ${ }^{357}$ and Morgan ${ }^{358}$-but also of the nineteenth-century treatises-Evans, ${ }^{359}$ Starkie, ${ }^{360}$ Best, ${ }^{361}$ and Rapalje. As late as 1887 , Rapalje wrote that if a more modern comparison of witness credibility fails to settle a conflict in oaths, then "the testimony of the greater number... must prevail." ${ }^{362}$ We see numerology in case law as well. In

356. BEST, supra note 112 , $\$ 397$, at *436.

357. Gilbert suggested that numerology should be the second rule of docision, after Bethel's rule, whenever a jury faced conflicting oaths. See supro lext accompanying notes 352-354. If two witnesses agree, he wrote, "there must be two perjured, or it must be true what these Witnesses alledge." GIL.jekt. supra note 70 , at 153 .

358. Morgan's treatment of the issue follows Gilbert almost verbatum. Compare I MORGAx, supra note 227, at 296, with GLLBERT, supra note 70, at 157.

359. See Evans, supra note 231, at 262 ("Other circumstances being equal, the preponderance of numbers is certainly entitled to the advantage, and sometimes this preponderance will be sufficienily great to counterballance an apparent superiority in other circumstances on the opposite side . . . . $)$. Consistent with his modern views, however, Evans made clear that "consideration of number is held subordinate to that of . . . individual veracity." Id.

360. See 1 STARKIE, supra note 233, $\$$ LII, al *79 ("[I]t is for the jury afterwards to judge of the credit due to the witnesses, considering their numbers, their opportunitues for observing the facts . . ."): id. $\$ \mathrm{LV}$, at *454-55 ("The credit due to the testimony of witnesses depends upon 1st. their honesty: 2dly, their ability; 3 dly, their number, and the consistency of their testumony . . . "): td. \$ LVIII, al " 465 ("Where direct testimony is opposed by conflicting evidence, or by ordinary expenence, or by the probabilutues supplied by the circumstances of the case, the consideration of the number of witnesses becomes most material."); id. § LXXXIV, at *522 ("[W]here the credit of conflicung witnesses is doubtful, as far as regards their number, their integrity. their means of knowledge, and the consistency and probabslity of thetr testimony, a comparison of their statements with each other and with undisputed or established facts is the great test of credibility.").

361. See supra text accompanying note 356.

362 . RAPALJE, supra note 231 , § 194, at 323. 
1851, a Texas trial court advised the jury that when witnesses are of equal credit, "the jury are authorized to allow the greater number of witnesses to preponderate"363 - an instruction to which a three-judge special court of the state supreme court gave its "entire assent." 364 The Arkansas Supreme Court stated a similar principle in $1859 .{ }^{365}$ It is true that stark references to the rule of numbers grow harder to find as the years go by, but the important thing is how late in our story we continue to find them. ${ }^{366}$

We may add numerology to that list of rules and principles-which now includes competency rules, Bethel's rule, the rule that juries must accept the sworn testimony of an unimpeached and uncontradicted witness, and the presumption that sworn testimony is true-that disclose the system's continuing reluctance to let the jury play the role of lie detector. Before we move on in Part IV to examine the nineteenth-century demise of many of these rules, let me add one more to the list. The rule of falsus in uno, falsus in omnibus held that a witness who lied about any material fact must be disbelieved as to all facts. As Thomas Starkie argued in his 1824 evidence treatise, the rule created an exception to the usual presumption that sworn evidence was true: "The presumption that the witness will declare the truth ceases as soon as it manifestly appears that he is capable of perjury. Faith in a witness's testimony cannot be partial or fractional . . .."367

363. Coles v. Perry, 7 Tex. 109, 140 (1851) (quoting the trial judge's instruction).

364. Id.

365. See Vaughan v. Parr, 20 Ark. 600, 607 (1859) (holding in a nonjury case that when no witness is impeached and all had an equal opportunity to gain information, "the testimony of the greater number must prevail").

366. It is not hard to find 20th-century examples, though they tend to be weaker formulations of the rule. See, e.g., Davies v. Philadelphia Rapid Transit Co., 77 A. 450, 451 (Pa. 1910) ("In a conflict of evidence, mere number is not in itself controlling, but it certainly is entitled to great consideration, and should control unless there be special reason to credit the evidence of the smaller number."). In 1918 a California civil trial court advised the jury: "[Y]ou are . . to bear in mind the number of witnesses testifying for or against any issue of fact in determining where the preponderance of proof lics." Hanton v. Pacific Elec. Ry., 174 P. 61, 63 (Cal. 1918) (quoting the trial judge's instructions). The court then added: "By a preponderance of the evidence is not necessarily meant a greater number of witnesses, and if the plaintiff has proven his case by such evidence as constitutes and produces conviction in the mind of the jury, then he has proven his case by a preponderance of the evidence." Id. (quoting the trial judge's instructions) (emphasis omitted). In approving this instruction, the California Supreme Court cmphasized the trial judge's permissive, nonexclusive statement of the numerology principle. See id. I thank Dan Klerman for this reference.

Wigmore found it "surprising" how late the principle of numerology, long a fixture of Roman-canon law, persisted in English common law courts:

[A]s a popular notion and instinctive mental attitude it was still in almost full force in the

$1500 \mathrm{~s} . .$. . The vital force of this quantitative view of a witness' testimony is seen pressing to the surface in abundant casual instances down into the 1700's; and it is only here and there that a protest is raised against its fallacy.... Only by a slow and comparatively recent development came the rational notion of analyzing and valuing testimony other than by numbers. Even to-day, among juries in some places, there is no doubt a mere counting of oaths or witnesses.

Wigmore, supra note 43 , at $89-90$. As Wigmore sought to minimize the role played by numerology in English common law courts, see id. at $94,97-98$, he called no attention to the principle's survival in 19thcentury treatises and case law.

367. I STARKIE, supra note 233 , \& LXXXVII, at *524. 
In its original form, the rule of falsus in uno was mandatory. "The notion," Wigmore wrote, "was that the testimony of one detected in a lie was wholly worthless and must of necessity be rejected." 368 The rule, therefore, served as one more mechanical guide by which the system withheld lie-detecting powers from the jury. Like the rule that the greater number of witnesses should prevail, that of falsus in uno came into play only in those situations, such as alibi defenses, that were resistant to Bethel's rule. Starkie maintained that juries should deal with apparent conflicts of oaths in this now-familiar manner:

Where the testimony of direct witnesses is apparently at variance, it is to be considered in the first place whether they be not in reality reconcileable, especially where there is no extrinsic reason for suspecting error or fraud. But if their statements upon examination be found to be irreconcilable, it becomes an important duty to distinguish between the misconceptions of an innocent witness, which may not affect his general testimony, and wilful and corrupt misrepresentations which destroy his credit altogether. ${ }^{369}$

That is, if the jury cannot reconcile two oaths, as recommended by Bethel's rule, it should apply one of the mechanical lie-detecting rules supplied by the system - in this case, the rule of falsus in uno.

By the early nineteenth century, English judges were telling juries that they might-but need not-disbelieve the entire testimony of a witness who had lied about a material fact. ${ }^{370}$ In America, the mandatory form of the rule died more slowly. Despite attacks by treatise writers and some courts on the rule's wooden conception of human credibility, ${ }^{371}$ and despite modern-sounding arguments that it impermissibly invaded the jury's prerogative to judge credibility, ${ }^{372}$ many courts continued to instruct juries that they must adhere

368. 3 WIGMORE, supra note 44 , 1009 , al 675 . Wigmore traced the rule of falsus in uno to the Stuan treason trials of the late 17th century. See id. $\$ 1008$. at $675 \mathrm{n}$ I: see also. $e \mathrm{~g}$. Tnal of Hampden, 9 Howell's State Trials 1053, 1101 (1684) ("Falso in tuno. falsus in ommbus. If we can prove that what he hath said of my lord of Essex is false, he is not to be believed aganst the defendant."). Tnal of Langhom. 7 Howell's State Trials 417, 478 (1679) ("If I can prove any one point (in answer to that which he hath given evidence) not to be true, then I conceive, my lord. he ought to be set aside."): Tnal of Coleman. 7 Howell's State Trials 1, 71 (1678), quored in KeNYON, supra note 162, at 125 ("[I]t would much ennervale any man's testimony, to the whole, if he could be proved false in any one thing."). Although Wigmore did not find earlier expressions of the rule, its repeated appearance in the inals of this era suggests it had earlier roots. Barbara Shapiro notes that Michael Dalton's early-17th-century manual for justuces of the peace advised magistrates that when examining accused felons, they should discredıt the whole of the aceused's story if any part proved false. See SHAPiRo, supra note 28, at 156. 279 n. 16.

369. I STARKIE, supra note 233 , \& LXXXI, al *515.

370. See 3 WIGMORE supra note $44, \S 1010$. at 676 .

371. See, e.g., Parsons v. Huff, 41 Me. 410.412 (1856) (Appleton. J) ("It is obvious, therefore, that of the testimony of the same witness part may be true and reluable and part false and mendacious. A rule of law, which requires a jury to infer from one false assertion. that all facts uttered by the witness are false statements, is manifestly erroneous."); 3 GREENLEAF. supra note 231 . \$378. at 382 (arguing that because cross-examination may pressure witnesses into making mistakes, it would be "unjust" to apply the rule to witnesses testifying orally).

372. See, e.g., Knowles v. People. 15 Mich. 408.412 (1867) (".lW]hen tesumony is once before the 
to the rule. ${ }^{373}$ The Supreme Court endorsed a mandatory form of the rule as late as $1822,{ }^{374}$ as did some state courts well into the twentieth century. ${ }^{375}$

\section{THE RISE OF DEFENDANT TESTIMONY}

In earlier pages, I have now and then glanced ahead of our story to the events of the nineteenth century. Bethel's rule, as I noted, survived into the nineteenth century but did not long outlive it, and the same may be said of the rules of numerology and falsus in uno. But even before the nineteenth century opened, there had been hints of a broader change to come. Cracks had begun to show in the complex of competency rules that had served to keep the most probably perjurious witnesses from taking the stand. In a much-quoted passage from 1786, Lord Mansfield remarked that "of late years the Courts have endeavoured, as far as possible, consistent with [the old] authorities, to let the objection go to the credit, rather than to the competency, of a witness." 376 That is, some courts had begun to construe competency rules narrowly, permitting challenged witnesses to testify and letting the jury judge their credibility. By the first years of the nineteenth century, Leonard MacNally could begin a general treatise on evidence in criminal cases with the bold claim that a jury could reject the testimony even of a sworn, positive witness if the jury was suspicious of the witness's "excess of warmth" or his "solicitous reserve" or even his "affectation of candor."377

But Mansfield's dictum and MacNally's rhetoric came a few decades ahead of their time. Although there had been some common law erosion of rules that once had protected juries from the task of lie detecting, the old

jury, the weight and credibility of every portion of it is for them, and not for the court, to determine."); State v. Williams, 47 N.C. (2 Jones) 257, 269 (1855) (Pearson, J.) (holding that any attempt to regulate a juror's judgment of a witness's credibility "is impracticable, worse than useless, inconsistent and repugnant to the nature of a trial by jury"); Mead v. McGraw, 19 Ohio St. 55, 62 (1869) (stating that "the passing upon the credibility of witnesses is exclusively within the province of the jury"); RAPALJE, supra note 231, $\S 192$, at $318-19$ (arguing that the "true rule" is that the jury "are authorized" to reject the whole of the witness's testimony, but "the question of credibility remains wholly with the jury").

373. See 3 WIGMORE, supra note $44, \S 1009$, at $675 \&$ n.2 and cases cited therein. In New York, confusion persisted about whether the mandatory or permissive form of the rule governed until the late 19th century. See id. § 1010, at 678 n.2.

374. The Santissima Trinidad, 20 U.S. (7 Wheat.) 283, 339 (1822) (holding that when a witness tells a "deliberate falsehood ... Courts of justice . . . are bound ... to apply the maxim falsus in uno. falsus in omnibus").

375. See, e.g., Pass v. State, I 82 S.E.2d 779, 788 (Ga. 1971) (citing the trial judge's charge that, "if a witness shall swear wilfully and knowingly falsely, his or her testimony shall be disregarded entirely unless corroborated by circumstances or other unimpeached evidence"). This case dealt with a variant of the mandatory form of the rule in which the jury is told that if the witness has lied about one fact, the jury must disbelieve the witness as to all other facts unless those facts are corroborated, in which casc the jury may give them credit. See 3 WIGMORE, supra note $44, \S 1011$, at 678 \& n.1.

376. Walton v. Shelly, 1 Term. Rep. 296, 300 (K.B. 1786), quoted in, e.g., 3 BLACKSTONE, supra note 89, at *369 n.*; MACNALLY, supra note 319 , at 124; see also Oldham, supra note 204 , at 111 \& $n .81$ (citing a general 18 th-century trend, led by Mansfield, toward letting a witness's interest go to credibility rather than competency).

377. MACNALLY, supra note 319 , at $2-3$. 
competency rules survived the turn of the century in almost undiminished force. Criminal defendants, civil parties, interested persons, felons, spouses, and nonbelievers remained ineligible to testify in every jurisdiction, Mansfield's manifesto of change notwithstanding. The only clear step toward the vast transformation that lay ahead was an emerging tolerance of witnesses of different faiths. Early in the seventeenth century, Lord Coke had insisted that only Christians could be trusted with the oath. ${ }^{378}$ By the end of the eighteenth century, courts had ruled that the only essential theology for a witness was a belief in divine retribution for falsehoods told under oath. ${ }^{379}$ As early as 1696, English law permitted Quakers, who would not swear, to testify by affirmation in civil cases. ${ }^{380}$

This liberality toward non-Christian and Quaker witnesses may have been a symptom more of religious tolerance than of any diminished regard for the value of the oath. We still can see at the beginning of the nineteenth century the old, highly formalized attitudes that, on the one hand, presumed sworn evidence to be truthful and, on the other, protected that presumption by attempting to keep potential liars from taking the oath. Hence Starkie, like Gilbert, staked the logic of Bethel's rule on "the presumption in favour of human veracity." 381 And in language much like that of Gilbert a century earlier, Starkie and others justified the panoply of competency rules in terms of their power to protect the oath by preventing probable perjurers from defiling it. An interested person may not take the oath, Starkie said, because human nature "is too weak to be generally restrained by religious or moral obligations, when tempted ... by temporal interests." ${ }^{382}$ Nor may a felon, "for it cannot reasonably be expected that such a person would regard the obligation of an oath." ${ }^{383}$ Nor may a nonbeliever, for "that obligation to speak the truth is wanting which the law has appointed . . . as an indispensable security." 384

By resorting to this contrivance of competency rules to protect the oath's role as a guarantor of truth, the system betrayed its persistent doubt about the

378. See Edward Coke. The first Part of the INSTITUTES of the LAwS of ExGland, Or, A COMMENTARY UPON LITTLETON 6 b (London, J. \& W.T. Clarke 19th od. 1832) (1628).

379. The pathbreaking case was Omichund : Barker. Y.B. $18 \mathrm{Gco}$. 2. Hil. I (Ch 174-1), reprnted in Reports of Adjudged Cases in the Court of Comimon pleas during the Tiae lord Chief Justice Willes Presided in that Court; TOgethier wTti SOME few Cases of thie SaMe Period DETERMINED IN THE HOUSE OF LORDS. COURT OF CHANCERY, AND EXCHEQLER CHAMGER (Dumford) 538 (London, John Exshaw 1800) [hereinafter DURNFord]. Justice Willes's opinion was often quoted. "[N]othing but the belief of a God and that he will reward and punish us according to our deseris is necessary to qualify a man to take the oath." Id., reprinted in DuRNFord. supra. at 5.45

380. See An Act That the Solemn Affirmation and Declaration of the People Called Quakers. Shall Be Accepted Instead of an Oath in the Usual Form, 7 \& 8 Will. 3. ch 34 (1696). Quaken could not give evidence by affirmation in criminal cases until 1828. See An Act for Amending the Law of Evidence in Certain Cases, 9 Geo. 4 , ch. 32 (1828).

381. I STARKIE, supra note 233. \& LXXXII, at *517

382. Id. § LVIII, at *83.

383. Id.

384. Id. § LVI, at *82. 
jury's capacity to spy out and disregard a perjured witness. Greenleaf admonished in his 1842 treatise, "If no means were employed totally to exclude any contaminating influences from the fountains of justice," the jury would "constantly" give "the testimony of a witness, unworthy of credit, .. . as much consideration as that of one, worthy of the fullest confidence." ${ }^{385}$ And yet this cardhouse of competency rules collapsed. One by one, first in the civil context and then in the criminal, both in England and in America, the rules came down. Although I will speculate below on some forces that might have sped the rules' demise, I cannot pretend to have found the moving force behind each step in this progress toward modernity. Instead I will focus on the last, most dramatic, and (in the criminal context) by far most important step: the downfall of the rule that forbade criminal defendants to testify under oath.

Maine led the common law world when it gave accused felons the right to the oath in 1864. Many states quickly followed, almost all of them Northern. Seeking an explanation for this North-first movement to permit defendant testimony will require us first to explore another North-first phenomenon, for it turns out that competency rules barring civil parties from testifying also came down in the North before the South. I will argue that in both cases the North acted first because of the distorting influence of a related but quite different issue-the right of nonwhites to give evidence in Southern courts.

The relationship between Southern laws that barred nonwhites from the witness stand and the Southern lag in permitting civil parties to testify was, as we will see, quite direct. But tracing the link between the South's racial exclusion laws and the North's lead in letting criminal defendants testify will take us out of the courtroom and into the political maelstrom. We will begin in the U.S. Senate in 1862, when Charles Sumner first launched his attack on the South's racial exclusion laws. ${ }^{386}$ Sumner and his followers did not in the main attack the racist underpinnings of the South's laws. Instead they framed their objections in the same general language that legal reformers had brought to bear against the whole structure of witness competency rules. They argued that all competency rules withhold useful evidence from the jury and thereby hinder the search for truth. The consequence of relying on such arguments was ironic, if not entirely unpredictable: Suddenly, any surviving Northern competency rule left the North vulnerable to Southern countercharges of hypocrisy. The bar against sworn testimony by criminal defendants, therefore, suddenly had to go.

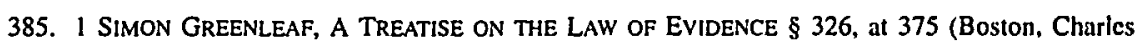
C. Little \& James Brown 1842).

386. See infra Subsection IV.D.1. 


\section{A. The Downfall of Witness Competency Rules in Civil Cases}

A generation before the American Civil War made its unexpected appearance in our story, the old system of competency rules had begun to crumble, especially in their application to civil cases. In England, Lord Denman's Act of $1843^{387}$ abolished the exclusion of both felons and interested persons; the County Courts Bill ${ }^{388}$ of 1846 permitted civil parties to testify in the county courts, which had jurisdiction over minor civil actions; Lord Brougham's Act of $1851^{389}$ abolished the exclusion of civil parties in all courts; an act of 1853 abolished the exclusion of spouses in civil actions; ${ }^{390}$ and an act of 1869 abolished the exclusion of atheists in all cases. ${ }^{391}$ In the United States change was, by the nature of the land, piecemeal and uneven, but unmistakable nonetheless. Michigan became the first state to permit interested witnesses to testify in $1846^{392}$ and Connecticut the first to admit civil parties in $1848 .^{393}$ Other states followed, with changes in almost all cases coming in the form of legislative action.

It is not easy to isolate the driving force behind the liberalization of competency rules in civil cases, though three explanations stand out. The first of these points to the influence of Jeremy Bentham's Rationale of Judicial Evidence, first published in English in $1827 .{ }^{394}$ In five turgid ${ }^{395}$ volumes, Bentham made it relentlessly, repetitively clear that the oath provides no guarantee of truthful testimony, ${ }^{396}$ that we must rely on the jury to separate wheat evidence from chaff, ${ }^{397}$ and that the more evidence we place before

387. An Act for Improving the Law of Evidence. $6 \& 7 \mathrm{Vict}$, ch $85 . \$ 1(1843)$ Although this was the earliest general assault on the principle of competency rules in Great Britan. carlice laws had made limited inroads. See, e.g., An Act for the Further Amendment of the Liw, and the Belter Advancement of Justice, 3 \& 4 Will. 4, ch. 42, $\$$ 26-27 (1833) (lımiung the grounds on which a person may be disqualitied by reason of interest); An Act To Render Persons Convicted of Pelly Larceny Compelent Witnesses, 31 Geo. 3, ch. 35 (1791) (declaring that no person shall be incompelent as a witiness by reason of a petty larceny conviction).

388. An Act for the More Easy Recovery of Small Debts and Demands in England, 9 \& 10 Vict., ch $95, \S 83$ (1846).

389. An Act To Amend the Law of Evidence. $14 \& 15$ Vict., ch. $99 . \$ 2$ (1851)

390. See An Act To Amend an Act of the Foureenth and Fifteenth Victona. Chapter $99.16 \& 17$ Vict., ch. 83, §§ 1-2 (1853). (1869).

391. See An Act for the Further Amendment of the Law of Evidence. 32 \& $33 \mathrm{Vict}$, ch $63 . \$ 4$

392. See Joel N. Bodansky, The Abolition of the Part-Witness Disqualification An Histortcal Survev, 70 KY. L.J. 91,93 (1981-1982).

393. See CONN. Rev. STAT. tit. I. ch. X. § 141 (1849).

394. See 1 Jeremy Bentham, Rationale of JtDicial Evidesce (John S. Misll ed . London. Hunt \& Clarke 1827). Bentham wrote his Rationale between 1802 and 1812 A inucated version appeared in French in 1823. John Stuart Mill, editor of the 1827 English edition. also urote parts of that text. See id. at $x$-xii; A.D.E. Lewis, The Background io Benthom on Evirdence, 2 UTILTAS 195. 204-09. 213. 216 (1990)

395. An early reviewer wrote of the Rationale: 'A $A$ book more disgusungly affected and so nearly unintelligible it is not possible to imagine." Paul A. Palmer, Benhamism in England and America. 35 Av POL. SCI. REv. 855,859 (1941) (quoting Thomas Cooper's 1830 review)

396. See, e.g., I BENTHAM, supra note 394, at 366.

397. See, e.g., 5 id. at 13-17. 
the jury, the more likely the jury is to arrive at the truth. ${ }^{398}$ Historians have disputed the extent of Bentham's influence. Holdsworth attributed the passage of Lord Denman's Act to the force of Bentham's reasoning. ${ }^{399}$ A more recent study has traced the downfall of competency rules to the work of Bentham and a handful of his disciples on both sides of the Atlantic. ${ }^{400}$ One of those disciples, John Appleton of Maine, said plainly that he had "only endeavored to apply the reasoning and principles of Bentham." 401 Yet Barbara Shapiro argues that Bentham squandered his influence in bitter attacks on the legal profession and in his nihilistic vision of the rules of evidence and that he had little impact on the course of law reform. ${ }^{402}$ And Christopher Allen says flatly that Bentham "played little or no part" in bringing down competency rules based on religious beliefs. ${ }^{403}$ For all its vivid bombast, Bentham's Rationale is long and impenetrable. Judging from the indifference shown it by other major evidence scholars of the century, ${ }^{404}$ we perhaps can conclude that Bentham's influence, although real, was less than it appears.

The second and third possible explanations for the downfall of competency rules in civil cases rely less on the influence of a maverick thinker, but each has other shortcomings. It would be attractive to think that competency rules were a victim of the progressive "lawyerization" of the courtroom. John Langbein's pathbreaking work has shown the increasing involvement of prosecution and defense lawyers in English criminal courts in the eighteenth century. ${ }^{405}$ With lawyers, of course, came cross-examination, that greatest of tools for the ascertainment of truth. Perhaps competency rules began to fall

398. Most of Bentham's treatment of the wrongfulness of excluding evidence from the jury may be found in 4 id. at 477-514; and 5 id. at 1-59, 78-107, 125-45, 207-20, 350-415, 463-81.

399. See 9 HoLDSWORTH, supra note 43, at 193.

400. See Bodansky, supra note 392, at 94 (noting the infiuence of Lords Denman and Broughum in Britain and Edward Livingston and John Appleton in the United States).

401. JOHN APPLETON, THE RULES OF EVIDENCE at iv (Philadelphia, T. \& J.W. Johnson 1860).

402. See SHAPIRO, supra note 28, at 36. Rejecting another of Bentham's proposed reforms, Joseph Story wrote in 1837, "'We have not yet become votaries to the notions of Jeremy Bentham."' MICHAEL. STEPHEN HINDUS, PRison AND Plantation 189 (1980) (quoting Story).

403. See C.J.W. Allen, Bentham and the Abolition of Incompetency from Defect of Religious Principle. 16 LEGAL HIST. 172, 185 (1995). Seeking to explain why Bentham's influence on American political thought "was so slight," Paul Palmer noted that "such of Bentham's writings as were known in this country by about 1860 were not in themselves capable of arousing and sustaining widespread interest in utilitarian doctrine." Palmer, supra note 395 , at $855,859$.

404. Best's 1849 treatise, for example, professes a decided ambivalence toward Bentham's ideas. Although Best admitted he made "[1]arge use" of the Rationale, he immediately added that it "embodics several essentially mistaken views relative to the nature of judicial evidence." Preface to BEST, supra note 112 (unpaginated). Best cited Bentham's disdain for the oath, see id. $\$ 57$, at *54, but approved the lesson of history that the oath "has in every age been found to supply the strongest hold on the consciences of men," $i d$. $\$ 55$, at *51. Best did, however, largely follow Bentham's condemnation of witness competency rules. See id. $\$ 60$, at $* 60-61$. And Thayer credited Bentham with great influence. See James Bradley Thayer, A Chapter of Legal History in Massachusetts, 9 HARV. L. REv. 1, 1-2, 12 (1895-1896).

405. See Langbein, supra note 88, passim; cf. Michael Jonathan Millender, The Transformation of the American Criminal Trial, 1790-1875, at 36 (1996) (unpublished Ph.D. dissertation, Princeton University) (on file with author) ("In America, as in England, the pervasive use of lawyers in criminal trials was an eighteenth-century phenomenon."). 
from favor as skilled cross-examination by counsel equipped juries to make more searching evaluations of witness credibility. This argument, however, must confront two disagreeable facts. First, competency rules dissolved more quickly in the civil context-there was considerably more resistance to change on the criminal side. Second, there is little reason to think that cross-examination by lawyers was a new phenomenon on the civil side of eighteenth-century courthouses. ${ }^{406}$ So although advancing lawyerization may supply part of the explanation for the new nineteenth-century disaffection with competency rules, it is unlikely to supply the whole answer.

The last of the seemingly plausible causes of the rules' demise looks to prevailing political philosophies in the society at large. The American experience, examined alone, might support the hypothesis that the Jacksonian triumph of the common citizen of the 1820s and 1830s forced an enlargement of the jury's power in the $1840 \mathrm{~s}$ and $1850 \mathrm{~s} .{ }^{407}$ Competency rules that withheld from the jury the task of assessing certain witnesses' credibility perhaps fell from political favor. But this explanation cannot account for the downfall of competency rules in England-and at least in the civil context, Parliament tended to be one step ahead of all but the most progressive American states. As we will see shonly, although American states took the lead in eliminating the incompetency of criminal defendants, the pattern of state enactments gives no support to the Jacksonian hypothesis.

Where then will we find an explanation for the death of competency rules in civil cases in the 1840s and 1850s? I will set out some thoughts in more detail in Part V. For now, perhaps it is enough to suggest that the abolition of civil competency rules in the nineteenth century simply may have been one small event within a broad, long-term transformation of the nature of factfinding in jury trials. That transformation embraced two countervailing currents of change. On the one hand, the system increasingly lost confidence in the power of the oath to assure the legitimacy of verdicts. On the other, the system invested ever greater confidence in the jury's capacity to resolve factual disputes. Given these trends, the contours and causes of which I will explore later, it was perhaps inevitable that competency rules would meet their doom. Competency rules were the product of an age that mistrusted the jury's power

406. See Langbein, supra note 286, at 1201 ("The presence of opposing counsel was a novelly in criminal cases in the second half of the eighteenth century, but it was routune in civil cases.") Tom Gallanis advises me that his ongoing work "suggests that the lawyerization of the criminal tnal did have effects on the conduct of civil litigation, as lawyers who began their careers in the rough-and-tumble arena of the Old Bailey (e.g., William Garrow) began to develop civil practsces." Lelter from Thomas Gallanıs. Professor. Ohio State University College of Law (Sept. 2. 1997).

407. Alexis de Tocqueville, an adroit observer of Jacksonian Amenca. remarked that "[t]he system of the jury, as it is understood in America, appears to me to be as direct and as extreme a consequence of the sovereignty of the people as universal suffrage." ALEXIS DE TOCQLEVILLE. DENOCRACY IN AMERICA 362 (Henry Reeve trans., New York. The Century Co. 1898) (1835): see also MARvis MEYers. THE JACKSONIAN PERSUASION: POLITICS AND Belief 24-4l (1957) (endorsing Tocqueville as "a key 10 Jacksonian America"). 
to spot the truth and trusted instead the truth-assuring powers of the oath. In barring liars from access to the oath, the rules served to preserve the illusion that the oath guaranteed truth. By the nineteenth century, the tension between the broader historical trends and the anachronistic survival of the rules simply had grown too great. Only a triggering event-perhaps Bentham's Rationale, perhaps some other force not yet identified-was needed to bring the rules crashing down.

\section{B. The Downfall of the Prohibition Against Defendant Testimony in Criminal Cases}

Whatever may have triggered the downfall of competency rules in civil cases, it had little impact on the competency rule that most concerns us in this study of lie detection in criminal cases: the rule that barred criminal defendants in both felony and misdemeanor cases from testifying under oath. In England, that rule did not come down in all cases until $1898,{ }^{408}$ forty-seven years after civil parties gained the right to give evidence. In America the gap between the first state to let civil parties testify (Connecticut in 1848) (09 $^{40}$ and the first to let all criminal defendants testify (Maine in 1864) (10 $^{40}$ was smaller but still clear. Bringing about the downfall of the defendant testimony bar required a different triggering event—one more momentous than Bentham's writing and, as we will see, more peculiarly American.

The rule prohibiting defendant testimony stood in tension with the broad historical trends away from reliance on the powers of the oath and toward greater jury autonomy in factfinding. There are two fairly obvious explanations for the rule's staying power in the face of this historical transformation. First, the old competency rules had served to keep likely liars from the witness stand-and the most likely liars of all were criminal defendants, who had by far the strongest motivation to lie. Hence Justice North, at Stephen Colledge's 1681 treason trial, made it clear that what Colledge said held no weight: "Why if yours or any other man's word in your case should go for truth, no man that stands at a bar, could be convicted: For every man will say he is an honest man...."411 When late-nineteenth-century legislators considered the

408. See An Act To Amend the Law of Evidence, 61 \& 62 Vict., ch. 36 (1898).

409. See infra Table 2.

410. See infra Table 1.

411. Trial of Stephen Colledge, 8 Howell's State Trials 549, 681 (1681). Lest Colledge had missed the point, North said it two more times. See id. at 625 (" $[N]$ othing you say is to be believed upon your own allegation: for then no man would ever be guilty, if his own purgation by words were to be believed."); id. at 681 ("I must tell you, all the course of justice were destroyed, and no justice against malefactors were to be had if the word of him that is accused should pass for proof to acquit him."). North instructed the jury in similar terms:

[Y]ou are not to consider any thing of the facts the prisoner speaks of, that are not proved . . . ; for common justice is concerned in it, and no justice can be done at that rate, if the prisoner's own affirmations or purgation should be taken. No man ever can be accused but he will be 
abolition of the defendant testimony rule, even moderate observers predicted "perjury on every occasion," "412 a "fearful and overpowering temptation to perjury," 413 a "habitual spectacle of this wholesale perjury," "pis "perjury upon a gigantic scale." 15

Second, the task of resolving a conflict of oaths promised to be far more difficult in criminal than in civil cases. Once civil parties were permitted to testify, it was inevitable that civil juries would face conflicting oaths. A Massachusetts lawyer observed in 1861 that such conflicts put great demands on the jury's power to detect lies:

[A]s an eminent Massachusetts judge lately remarked in a charge to a jury, the admission of parties imposes new and grave trusts upon jurymen, and makes their position more difficult and responsible than before. They are now called upon to decide between conflicting testimony which is equally of the highest class, and to determine between statements often totally irreconcilable, - either of which, if uncontradicted, would be decisive of the point at issue; and this, we hardly need say, requires the exercise of more than average judicial faculties. ${ }^{416}$

ready to say he is innocent.... And therefore these things must not weigh with you further than as was said, argues upon the proofs you have had

Id. at 712 . Justice Jones concurred. See id. at 681 ("Would you have the jun to believe you upon your word?").

412. JAMES FITZAMMES STEPHEN. A GENERAL VIEW OF THE CRIMIMAL LAH Of EMGLAVD 202 (London and Cambridge, MacMillan 1863), quoted in Alschuler, supro nole 71. al 2662 Stephen later reversed himself and supported defendant testımony laws See I STR:PHE), supra nole 28. at +4?. +4-4-45

413. Seth Ames, Testimony of Persons Accused of Crunc. I A4 L RE) 143 , 46 (1867) Ames, a justice of the Massachusetts Supreme Judicial Cour. predicted "such an accumulation of false and worthles, testimony in the criminal cours" that jurors "will habitually disbeliese all testumon! commg trom any defendants." Id. at 450.

414. Bodansky, stupra note 392, at 109 n.74 (quotung Parliamentan debates)

415. Id. at 110 (quoting Parliamentary debates) A great many commentator made sumulur points See. e.g., id. at 108-10 (quoting various British commentators): Departures from the Common Lum Rule as 10 Testimony by Husband and Wife, 3 CRIM. L. MAG. 155. 162 (1882). Roben Popper, Histon and Development of the Accused's Right To Testuf. 1962 Wasil U LQ 454. 459 n 29 iquoung Bisiop. CRIMINAL PROCEDURE $\$ 1187$, at 705-06 (1880)). After more than a centun of expenence with deicndant testimony, at least one commentator would conclude that these early doomsayers were nght See H Rtchard Uviller, Credence, Character, and the Rules of Evdence Seeing Through the Lar's Tule, $+2 \mathrm{DLKE} \mathrm{LJJ}$ 776,813 (1993) ("All guilty defendants who choose to tesufy will lie on the stand about anything that might improve their chances and about which they umagine thes can be persususic",

416. [George S. Hillard], Review of John Appleton. The Rules of Evidence Stated and Discussed. 9 ? N. AM. L. REv. 515, 524 (1861). Forsyth argued simularly:

The late change in the law, whereby parties in an action are mide admussible witnesses for themselves, has, I think, increased the importance as $\mathrm{kell}$ as the difficulty of the office of the jury.

$\ldots$

I am by no means disposed to deny that the admusston of pantes to gise evidence in a cause in their own behalf will facilitate the ends of jusuce. by promoung the discosen of iruth. but without doubt the temptation to perjury is thereby increased. and the tash of the jun will be often rendered more difficult and delicate. All this will impose upon the jun the tash of deciding more frequently than heretofore between opposite and conflicung statemenis, and require more than usual caution and intelligence on their part

FORSYTH, supra note 48 , at $380-82$. 
But as great as these new demands on the lie-detecting powers of civil juries may have been, they did not approach in difficulty the task that lay ahead for criminal juries if defendants won the right to take the oath. Because the civil standard of proof was a mere preponderance of the evidence, civil juries often could resolve credibility conflicts by deciding merely which witness was the more truthful.

The criminal standard of proof raised greater difficulties. If a defendant were permitted to proclaim his innocence under oath, the jury could not convict without first determining that the defendant's story was a lie beyond a reasonable doubt. ${ }^{47}$ It is true that ever since the Treason Act of $1696,{ }^{418}$ juries occasionally had faced conflicts of oaths in serious criminal cases. In the absence of the defendant's testimony, however, direct conflicts must have been rare. Earlier, I reported findings that in trials at the Old Bailey in the eighteenth century fewer than $20 \%$ of cases involved sworn defense witnesses who testified to factual matters (as opposed to the defendant's character). ${ }^{419}$ Kalven and Zeisel found in the 1950s that when the defendant did not take the stand, only $5 \%$ of criminal cases presented the possibility of conflicting eyewitness testimony ${ }^{420}$ There is no reason to think things were different in this regard in the nineteenth century. Moreover, when conflicts did occur in the years before defendants took the stand, Bethel's rule might have served to spare the jury the task of deciding which witness had lied. But Bethel's rule could not erase the direct conflict between a crime victim's sworn accusation and a defendant's sworn denial.

In any event, there was little sign in the early nineteenth century that the legal system was ready to put criminal juries to the task of resolving sworn credibility conflicts. The clearest indication that the system was not ready to do so was the stubborn defense by most commentators of the two-witness rule in perjury. ${ }^{421}$ Starkie's treatment of the problem highlights the threat that

417. Barbara Shapiro has argued that the beyond-a-reasonable-doubt standard of proof in criminal cases was an innovation of the late 18 th century and was not commonly applied until the 19th century. See SHAPIRO, supra note 28, at 21-25; Shapiro, supra note 118, at 170-75. By the time of Starkie's 1824 treatise, the modem distinction between the criminal and civil standards of proof was well-recognized. See 1 STARKIE, supra note 233 , § LII, at *450-51.

418. 7 \& 8 Will. 3 , ch. 3 ; see supra Section II.C.

419. See supra note 345 and accompanying text.

420. See KALVEN \& ZEISEL, supra note IS, at 139.

421. See, e.g., 1 MORGAN, supra note 227 , at 29 ("[O]ne witness is not allowed to convict a man indicted for perjury, because then there is only one oath against another."); PEAKE, supra note 112 , at 9 ("[T]here would be oath against oath, and both being equally entitled to credit the jury could not conclude that the defendant had sworn false."); PHILLIPPS, supra note 112, at 107 ("IT) he evidence of one witness is not sufficient ... because then there would only be one oath against another."). I speak somewhat loosely of the "two-witness rule" in perjury. Many commentators noted that one witness plus some form of corroboration would be sufficient to defeat the defendant's oath. See 1 GREENLEAF, supra note 385, \$ 257, at 293-95; PHILLIPPS, supra note 112, at 108.

Not all commentators agreed that a conflict of oaths in a perjury case must inevitably produce stalemate. Best wrote that "[a]ll oaths are not of equal value; for the credibility of the statement of a witness depends quite as much on his deportment and the probability of his story as on the fact of its being deposed on oath." BEST, supra note $112, \S 397$, at *435. Evans insisted that the factfinder must consider 
sworn defendant testimony must have posed in the eyes of contemporaries. In two successive passages of his treatise, Starkie made the following two points. First, he rejected Montesquieu's defense of the Continental rule requiring two witnesses in every case:

It has been alleged that two witnesses are essential to convict a man of a crime, for if there be but one, it is no more than the assertion of one man against that of another.

It is not easy to comprehend how the mere denial of guilt, by an accused person, whose life may depend upon the credit attached to that denial, is to be placed in competition with the testimony of a witness examined upon oath. According to this species of logic, if six men were to commit a crime, it would require the testimony of at least seven witnesses to convict them upon their joint trial. ${ }^{42}$

Then, in a footnote to this text, Starkie defended the two-witness rule in perjury prosecutions "upon grounds of strict principle, for there the oath of one witness is opposed to the oath of another witness."

On one page Starkie said it would be absurd to require two witnesses to rebut the defendant's unsworn statement. On the next page he held it a matter of "strict principle" to require two witnesses to rebut the defendant's oath. The difference, of course, was the sheer formalistic power of the oath. To grant this power to the defendant in every case would, one may presume, have produced Starkie's Continental nightmare: Whenever six defendants swore to their innocence, the government would have to present seven witnesses to convict them.

Whether for these reasons or for others, the triggering event that brought down competency rules in civil cases left the defendant testimony rule standing. In England, as I said, the defendant testimony rule did not fall until 1898. ${ }^{424}$ Not until 1864 did Maine become the first common law jurisdiction to permit defendants to testify under oath at serious criminal trials. ${ }^{425}$ But

who had the stronger "motives for falsehood"- the defendant when he gave his aath, or the person who made the accusation of perjury. See Evans, supra note 231. at 280.

422. I STARKIE, supra note 233 , § LVIII. at *464 (footnoles omitted).

423. Id. at *464-65 n.q; see also id. § XIX. at *399 ("So in the case of perjury two witnesses are essential, for otherwise there would be nothing more than the oath of one man against that of anothes, upon which the Jury could not safely convict." (footnote omı(tod)).

424. See supra text accompanying note 408.

425. There was one brief exception: In 1848, as pan of the same law that made civil partics competent, Connecticut granted competency to criminal defendants. See An Act for the Regulation of Civil Actions (adopted 1848) (codified at CONN. REv. STAT. (it. I. ch. X. \& I 11 (1849)). The legislature withdrew the grant in 1849, however, apparently by a unantmous vole. Even in 1867, when the Connecticut legislature debated the bill that eventually extended competency to defendants permanently. legislators remembered the $1848 \mathrm{Act}$ as a terrible mistake. See Accused Parfies Testifying for Themselves. HartFord DAILY TIMES, June 28, 1867, at 2 (reporing the remarks in a House debate of Mr. Graves, who sand that the defendant testimony law "was passed in 1848. and it worked so disastrously, that in 1849. after a single year's trial, there came up such a voice for its repeal, that the Legislature unanimously repealed it") 
after Maine acted, a rapid rush of states followed: By 1870, twelve states had passed legislation to permit defendants to testify under oath; by the end of 1880 , all but seventeen states and territories had done so. ${ }^{426}$

One might argue that we need not look very hard to find the force that triggered this American stampede to permit defendant testimony. An obvious explanation is at hand in the work of John Appleton, a self-avowed acolyte of Bentham and long-time advocate of laws permitting defendant testimony. ${ }^{427}$ In 1864, as chief justice of the Maine Supreme Judicial Court, Appleton had the clout he needed to bring about a change he had sought for some thirty years. To explain why so many states where Appleton held no particular influence followed so quickly along, one could argue that Appleton and Maine merely led the way toward an idea whose time clearly had come.

But this appealingly simple explanation confronts several stubbornly incompatible pieces of evidence. The first is that the legal commentary of the day gives no hint that the time in fact had come for this particular idea. Appleton began advocating an end to the ban on defendant testimony in $1835 .{ }^{428}$ In the thirty years that passed before the Maine legislature answered his plea, only one other American commentator stepped forward in support: Irving Browne, ${ }^{429}$ editor of the Albany Law Journal, who seemed unaware of Appleton's work. ${ }^{430}$ Legal commentators were not, it is true, lined up against Appleton—rather, the issue of defendant testimony attracted almost no

In 1859, Maine granted criminal defendants the right to testify in certain misdemeanor cases. See infra note 506 and accompanying text.

426. See Ferguson v. Georgia, 365 U.S. 570,577 n.6 (1961) (listing the dates when states permilted criminal defendants to testify); see also infra Table 1.

427. See John Appleton, The Admission of the Accomplice and of the Party to the Record in Criminal Procedure, 14 AM. JURIST \& L. MAG. 317 (1835); John Appleton, Admission of Parties in Criminal Procedure, 13 AM. JURIST \& L. MAG. 50 (1835).

428. See sources cited supra note 427.

429. Even Browne did not explicitly advocate that criminal defendants be permitted to testify until 1866, two years after passage of Maine's law. See B., Testimony of Parties in Criminal Prosecutions, 14 AM. L. REG. (U. PA. L. REV.) 129 (1866) [hereinafter B., Testimony of Parties]; cf. DAvID M. GOLD, THE SHAPING OF NINETEENTH-CENTURY LAW: JOHN APPLETON AND RESPONSIBLE INDIVIDUALISM $187 \mathrm{n} .11$ (1990) (identifying "B." as Browne). But in an 1857 article, Browne lent general support to the principles Appleton advocated and hinted that criminal defendants, like civil parties, should have the right to testify. See B., Of the Disqualification of Parties as Witnesses, 5 AM. L. REG. (U. PA. L. REV.) 257, 267-68 (1857) [hereinafter B., Of the Disqualification] (looking forward to the time "when all men, in the possession of their reasoning faculties, understanding the nature and believing in the sanction of an oath, shall be permitted to speak that which they do know").

Reviewing Appleton's treatise on evidence in 1861, Massachusetts lawyer George S. Hillard made clear his support for the abolition of the exclusion of civil parties, but left it unclear whether he also approved of Appleton's advocacy against the exclusion of criminal defendants. See Hillard, supra note 416. at $522-24$.

430. Browne wrote that Bentham was the only opponent to the rule barring civil partics, see B., Of the Disqualification, supra note 429, at 258, although Appleton had long advocated the downfall of that rule as well, see John Appleton, Admission of Parties in Courts of Equity, 10 AM. JURIST \& L. MAG. 5 (1833); John Appleton. Incompetency of Parties as Witnesses at Common Law, 8 AM. JURIST \& L. MAG. 5 (1832). In a later work, Browne acknowledged and praised Appleton's arguments. See B., Testimony of Parties, supra note 429 , at $138-39$. 
legal commentary at all. ${ }^{431}$ In 1867, after Maine and several other states had passed laws permitting defendant testimony, Seth Ames, a justice of the Massachusetts Supreme Judicial Court, complained that the new law in that state had passed with "very little discussion and with no great amount of inquiry." 432 The law cannot, Ames said, "be said to have been called for by any generally acknowledged necessity, or to be intended for the purpose of reforming any practical abuse or defect that had been a matter of general complaint." ${ }^{433}$ It was "not called for by the profession, not petitioned for by anybody." 434 And following New York's passage of a similar law in 1869, that state's highest court remarked that "[t]he act is not regarded with much favor by the bench, bar or the people." "4s

A second reason to doubt the theory that Appleton inspired the demise of the rule against defendant testimony is the unlikelihood that Appleton could have inspired any legal transformation at all. His articles on evidence from the 1820 s and 1830s, which spun out Bentham's ideas and advocated an end to most competency rules, seem to have sparked no intellectual discussion. The 1860 "treatise" that gathered together those essays almost without modification seems to have prompted only one critical notice. ${ }^{436}$ Lacking Bentham's originality and sheer brilliance, the treatise matched Bentham's verbosity and capacity for repetition. Yet some scholars seeking to explain the course of events have magnified Appleton's persuasive powers. ${ }^{47}$ One remarked on Appleton's "fluency" 438 and then reprinted this example of his prose:

"Innocence of the accused, then, being a presumption of law-the accusation in the outset being presumed untrue, the accuser's statements false, whether intentionally so or not is immaterial-the question would naturally arise, whether both, and if not both, which of the two, should be heard as a witness." ${ }^{349}$

By far the most substantial reason to doubt the Appletonian theory is that theory's inability to explain the very striking split between North and South

431. I have found nothing in American legal literature beyond Appleton's work specifically addressing the testimony of defendants in criminal cases before 1866. other than an 1858 repnnung of an English law joumal article. See Evidence of Parties in Crıminal Questions. 21 MONTILY L. REP 193 (1858) (repnnung an article from London Law Magazine and Law Revew').

432. Ames, supra note 413 , at 443.

433. Id.

434. Id. at 450; see also Millender. supra note 405. at 355 ("The arguments of the reformers, their judicial defenders, and their earliest admirers ... fat to show why legislatures adopted the reform with such alacrity despite the absence of complaints by judges, proseculors, or defense lauyers in the preceding decades.").

435. Connors v. People, 50 N.Y. 240, 243 (1872).

436. See Hillard, supra note 416.

437. See, e.g., Millender, supra note 405, at 277 ("Owing in no small part to Appleton's influence, competency rules ... fell in a wave of legislative reform that began in the $18400^{*}$ )

438. Popper, supra note 415 , at 454.

439. Id. at 461 (quoting APPLETON, supra note 401, at 123). 
in the pattern of states that acted to let criminal defendants testify. In the 1860 s, a dozen states took that step, all of them by legislation:

\section{Table 1. Statutes Permitting SWorn Testimony BY CRIMINAL DEFENDANTS ${ }^{400}$}

\begin{tabular}{|l|l||}
\hline STATE & YEAR \\
\hline Maine & 1864 \\
\hline California & 1866 \\
\hline Massachusetts & 1866 \\
\hline South Carolina & 1866 \\
\hline Vermont & 1866 \\
\hline Connecticut & 1867 \\
\hline Nevada & 1867 \\
\hline Ohio & 1867 \\
\hline Minnesota & 1868 \\
\hline New Hampshire & 1869 \\
\hline New York & 1869 \\
\hline Wisconsin & 1869 \\
\hline
\end{tabular}

With the striking exception of South Carolina, not a single Southern or border state falls in this list. If we look another decade down the road, the pattern becomes even more pronounced. By the end of 1880 , all but seventeen states and territories had passed defendant testimony laws, and of the outliers, all but four were ex-Confederate or border states. ${ }^{441}$ Not a single additional member of the old Confederacy had followed the trend. ${ }^{442}$

440. The information listed here comes from Ferguson v. Georgia, 365 U.S. 570, 577 n.6 (1961).

441. The four exceptions were Alaska, Michigan, Oklahoma, and Pennsylvania. Alaska, Michigan, and Oklahoma passed defendant testimony laws in 1899, 1881, and 1890, respectively. See id. at 577 n.6. In Pennsylvania, accused misdemeanants had been made competent in 1872. See An Act To Extend the Competency of Persons To Be Witnesses in Certain Criminal Cases, $1872 \mathrm{~Pa}$. Laws 34. Over the next several years, the legislature progressively broadened the privilege. See An Act Supplementary to an Act, Entitled "An Act To Extend the Competency of Persons To Be Witnesses in Certain Criminal Cases," 1874 Pa. Laws 294; An Act To Permit Defendants To Testify in Criminal Cases, $1877 \mathrm{~Pa}$. Laws 45 (generally granting defendants the right to testify but withholding it in certain cases); An Act To Permit Persons Charged with the Crime of Receiving or Buying Stolen Goods or Chattels, Knowing the Same to Have Been Stolen, to Testify in Their Own Behalf, No. 158, 1879 Pa. Laws 149; An Act To Permit Defendants To Testify in All Criminal Cases, $1885 \mathrm{~Pa}$. Laws 23 (removing all restrictions on defendant testimony).

442. In 1870, Florida gave criminal defendants "the right of making a statement to the jury, under oath." An Act Concerning Testimony, ch. 1816, 1870 Fla. Laws 13. Under this law, however, the defendant 
This striking geographical tilt prompts an obvious question: Was there something peculiar about North and South that led one of these regions but not the other to open the way to sworn testimony by criminal defendants? In seeking to unwind this mystery, we should begin by asking whether the same North-South bias prevailed in the earlier movement to permit civil parties to testify. A quick glance at a sample of thirty-two states suggests that, although the time lag between North and South in this case was somewhat shorter, the bias was just as pronounced:

\section{Table 2. Statutes Permitting Testimony by Civil Parties ${ }^{2+3}$}

\begin{tabular}{|l|l||l|l|}
\hline \hline STATE & DATE & STATE & DATE \\
\hline \hline Connecticut & 1848 & Florida & 1866 \\
\hline Vermont & 1852 & Virginia & 1866 \\
\hline Ohio & 1853 & North Carolina & 1866 \\
\hline Maine & 1856 & South Carolina & 1866 \\
\hline Rhode Island & 1857 & Georgia & 1866 \\
\hline Mississippi & 1857 & Missouri & 1866 \\
\hline New York & 1857 & Alabama & 1867 \\
\hline Massachusetts & 1857 & Illinois & 1867 \\
\hline New Hampshire & 1857 & Louisiana & 1867 \\
\hline Kansas & 1858 & West Virginia & 1868 \\
\hline New Jersey & 1859 & Tennessec & 1868 \\
\hline Michigan & 1861 & Pennsylvania & 1869 \\
\hline Indiana & 1861 & Texas & 1871 \\
\hline Oregon & 1862 & Kentucky & 1872 \\
\hline California & 1863 & Arkansas & 1874 \\
\hline Maryland & 1864 & Delaware & 1881 \\
\hline & & \\
\hline
\end{tabular}

was not to be examined or cross-examined or to be deemed a witness. See Hawkins v. Stale, $29 \mathrm{Fla} .554$. 556-57 (1892). An 1866 Florida law had granted a similar right "when in the opinion of the coun the ends of justice shall so require." An Act Conceming Testimony. ch. 1472. 1865 Fla. Laws 35 (adopted Jan. 16. 1866). Not until 1895 did the accused win the right to be "swom as a witness" and to be "subject to examination as other witnesses." An Act To Amend Section 2908 of Revised Statutes of Florida Relating to Swom Statement of Accused. ch. 4400,1895 Fla. Laws 162.

443. For citations to the relevant statutory provisions, sce infra Appendix A. 
Among the sixteen states listed in the left-hand column, which lifted their bar against the testimony of civil parties rather early, the only Confederate state is Mississippi, and the only border state is Maryland. The sixteen states listed in the right-hand column, which followed along somewhat later, include the remaining ten Confederate states and the remaining four border states-Missouri, West Virginia, Kentucky, and Delaware.

Legal historians have noted this unmistakable North-South split, ${ }^{44}$ but only Wigmore attempted an explanation. He argued that competency rules were the product of an older, more emotional culture, in which the "belief that a partisan would likely falsify, or at least distort unconsciously the truth, was then much closer than now to the facts of life."445 Although the "influence of scientific research and of industrial invention and organization [have] made for a more rational and less emotional life," he wrote, "we may see with our own eyes that [in the South] the emotional element... [still] predominates." ${ }^{446}$ It is hard to know what to make of this explanation. Wigmore offered no evidence beyond his own impressions that the South was more emotional and less rational than the North, nor did he clarify the connection between emotionalism and witness competency rules.

In any event, it is exceedingly unlikely that an explanation based on general reformist tendencies in the North versus the South will avail in this case. That is because the pattern of change on another question touching the conduct of jury trials showed a strong South-first bias very much unlike the pattern of defendant testimony laws. In 1795, North Carolina became the first state to forbid trial judges to comment on the weight of the evidence when charging a jury; Tennessee acted next in 1796, then Alabama (1807), Mississippi (1807), Maryland (1811), and Arkansas (1836) ${ }^{447}$ By 1864, every member of the Confederacy had barred judicial comment, as had three border states and twelve states of the Midwest or West. ${ }^{488}$ But in the entire Northeast, only Massachusetts had followed the trend. ${ }^{449}$ If, then, generalizations about North and South will not explain the patterns that now

444. See, e.g., 2 WIGMORE, supra note 44, § 579, at 701-02; Bodansky, supra note 392, at 93 n.8.

445. 2 WiGMORE, supra note $44, \S 576$, at 690 .

446. Id. at 691 .

447. See Kenneth A. Krasity, The Role of the Judge in Jury Trials: The Elimination of Judicial Evaluation of Fact in American State Courts from 1795 to 1913, 62 U. DET. MERCY L. REV. 595, 622-27 (1985); Edson R. Sunderland, The Inefficiency of the American Jury, 13 MICH. L. REv. 302, 307 (1914).

448. See Krasity, supra note 447 , at $622-27$. Laws barring judges from commenting on the evidence were not, I think, closely related in any causal way to the fall of the bar against testimony by civil parties or criminal defendants. These changes, although interestingly correlated in a negative way, occupied two largely separate historical eras. As each of the changes tended to put greater factfinding autonomy in the hands of jurors, it would take some effort and ingenuity to provide a unified theory that could explain a Northern bias in the case of defendant testimony laws and a Southern bias in the case of the earlicr laws barring judicial comment.

449. See id. 
concern us, we must look elsewhere. If we are to find the reason the South came late in dropping the bar against civil parties and the North came early in allowing testimony by criminal defendants, we must seek out an explanation peculiar to that time and place and in all likelihood linked to the conflict that then raged.

\section{The Link to African Americans' Right To Testifi: Civil Paries}

We should begin by examining those laws that abolished the old bar against civil parties, as this was the earlier movement. The most striking thing about Table 2, which dates the enactment of those laws. is not the pattern of states in the left-hand column. It should not much surprise us that the first American state to abolish the old competency rule did so in 1848. As I noted earlier, England had begun to dismantle its bar against civil parties with the County Courts Bill of 1846 and completed the process with Lord Brougham's Act of $1851 .^{450}$ That Connecticut and Vermont should have been the first to act also seems unremarkable. Whether these two New England states were responding to the English lead, or whether they and England were responding to the same sorts of impulses that brought down most civil competency rules in this era (a process I explored above) need not concern us now.

What is striking about Table 2 is the pattern in the right-hand column. The general reticence of the Southern states to permit civil parties to testify ended suddenly in 1866. I believe that both the initial reticence and the later sudden conversion of the Southern states trace to their old attachment to a wholly different and seemingly unconnected competency rule-that barring testimony by nonwhite persons. The following table, which lists all those states that at one time had racial exclusion laws, ${ }^{451}$ explores the relationship between the abolition of those laws ${ }^{452}$ and the end of competency rules barring civil parties. Note that not all states with racial exclusion laws were Southern:

450. See supra notes 388-389 and accompanying text.

451. Racial exclusion laws took different forms. Some barred tesumony by all nonu hites. some only testimony by African Americans and those of mixed black-white blood. Some barred all testımony by the specified class, while some permitted such testimony when not offered agannst whites

Louisiana did not have a racial exclusion law per se. but rather provided that nonwhite status could be used to impeach a witness. See LA. CIV. CODE. ANN. an. 2261 (1857) ("The circumstances of the witness being . . . a free colored person, is not a sufficient cause to consider the witness as incompetent, but may, according to the circumstances, diminish the extent of his credibiliy.") An act of March 13. 1867. at once eliminated this provision of Louisiana's code and made civil parties competent. with the same proviso that status as a pary "may diminish the extent of [the witness's] credibility." An Act To Amend and Re-Enact Article Twenty-Two Hundred and Sixly-One of the Cival Code of the Stale of Loulsiana. No. $70, \S 1,1867$ La. Acts 141, 143.

452. Just as racial exclusion laws took many forms, so did the law's that repealed those exclusions. As I will discuss below, see infra notes 517-525 and accompanying text. many such repeals were incomplete Califomia's 1863 repeal was particularly incomplete, grantıng Afncan Amencans the nght to testıfy while retaining the bar against other nonwhites. See Act of Mar. 16. 1863. ch. LXVIII. 1863 Cal. Sint. 60.60. 


\section{TABle 3. Abolition of Rules Against Testimony BY NONWHITES AND CIVIL PARTIES}

\begin{tabular}{|c|c|c|}
\hline State & $\begin{array}{l}\text { RACIAL EXCLUSION } \\
\text { ABOLISHED }^{453}\end{array}$ & CIVIL PARTIES AlLOWED ${ }^{4.4}$ \\
\hline Kansas & Feb. 12,1858 & Same \\
\hline Kentucky & Jan. 30,1872 & Same \\
\hline Louisiana $^{455}$ & Mar. 13, 1867 & Same \\
\hline Oregon & Oct. 11,1862 & Same \\
\hline North Carolina & Mar. 10, 1866 & Two Days Later \\
\hline South Carolina & Sept. 21, 1866 & Two Days Earlier \\
\hline Virginia & Feb. 28,1866 & Two Days Later \\
\hline California & Mar. 16, 1863 & Six Weeks Later \\
\hline Florida & Oct. 25,1865 & Three Months Later \\
\hline Alabama & Dec. 9, 1865 & Feb. 14,1867 \\
\hline Arkansas & Feb. 6,1867 & 1874 \\
\hline Delaware & Not Found $d^{436}$ & Apr. 6,1881 \\
\hline Georgia & Dec. 15,1865 & Dec. 15,1866 \\
\hline Illinois & Feb. 7, 1865 & Feb. 19,1867 \\
\hline Missouri & July 4,1865 & Mar. 20, 1866 \\
\hline Ohio & Feb. 10,1849 & Mar. 11, 1853 \\
\hline Tennessee & Jan. 25,1866 & Mar. 13, 1868 \\
\hline Texas & Oct. 8, 1866 & May 19,1871 \\
\hline West Virginia & Feb. 27, 1866 & Feb. 7, 1868 \\
\hline Indiana & Dec. 20,1865 & Mar. 17,1861 \\
\hline Maryland & July 2,1866 & Mar. 2, 1864 \\
\hline Mississippi & Nov. 25,1865 & 1857 \\
\hline
\end{tabular}

I have arranged the states in this order for a reason. The first group of states, which make up almost half the total, abolished their racial exclusion law and

453. For citations to the relevant statutory provisions, see infra Appendix B.

454. See supra Table 2.

455. As noted above, Louisiana did not have a racial exclusion law per se, but rather provided that nonwhite status could be used to impeach a witness. See supra note 451.

456. I have been unable to locate a statute repealing Delaware's racial exclusion law. It scems safc, however, to include Delaware among those states that repealed their bar against civil parties only after they had begun to permit nonwhites to testify. Nonwhites surely must have been testifying in Delaware by 1881 . 
their civil parties bar at or near the same moment. In the second group, the racial exclusion law came down first, with the civil parties bar following during the next several years. In only three of these twenty-two states did the civil parties bar fall first.

By focusing on the three anomalous states-Indiana, Maryland, and Mississippi-we can perhaps discover why states that had racial exclusion laws generally clung to their civil parties bar. Each of these three states dropped its civil parties bar even while excluding nonwhites from the witness stand. In doing so, they had to address this question: What happens when a party is not white? Indiana's 1861 statute resolved this difficulty in an unexpected way:

Every free white person of competent age shall be a competent witness in any civil cause or proceeding, and no person shall be disqualified as a witness . . . because such person is a pary in said action or proceeding.

... Provided, That where a negro, Indian, or person excluded on account of mixed blood is a party to a cause, his opponent shall also be excluded . . . .457

The state of Indiana apparently was willing to take inequality only so far. Although it chose to prevent nonwhites from testifying, it scrupled to pit a nonwhite litigant who could not speak at trial against a white adversary who could. ${ }^{458}$ Hence if one party was not white, then neither party could testify. ${ }^{459}$ The laws of Maryland and Mississippi did not similarly trouble themselves to assure a fair fight. Each state made civil parties competent and, within the same statute, made it clear that the state's racial exclusion law would remain dominant. ${ }^{460}$ Therefore nonwhites, even when parties, would be incompetent to testify, while their white opponents could testify against them.

As for the other nineteen states in Table 3, I suggest that they maintained the old bar against civil parties because their lawmakers saw no good way to reconcile testimony by parties with their racial exclusion laws. That is, they rejected both the Maryland-Mississippi solution and the Indiana solution. Even

457. An Act in Relation to Witnesses and To Repeal Section 238 of Aricle 13 of the Act. ch. XXVII. $\S 2,1861$ Ind. Acts 51, 52.

458. The Indiana legislature considered but rejected a proposal to permit testumony by nonwhites in the same session in which it made civil parties compelent. See 8 BREvier LEG. REP. 328 (Ind.) (Drapicr \& Drapier) (1861); House of Representatives, INDIANAPOLIS J., Mar. 4. 1861. at 2. The proponent argued that "parties dealing together, should be placed on equality as to the evidence of such transictions " Id. (remarks of Mr. Bundy).

459. A New Jersey statute of the same era expressed a simslar pnnciple more generally. See A Supplement to the Act Entitled "An Act Concerning Witnesses." $1859 \mathrm{~N} J$. Laws $489-90$ (providing thal no party may "be swom in any case when the opposite party is prohibited by any legal disability from being swom as a witness").

460. See Act of Mar. 2, 1864, ch. 109, § 1.1. 1864 Md. Luws 136. 136-37: An Act To Establish Circuit Courts, To Define Their Jurisdictions, and To Regulate the Practice Therein (adopted 1857) (codified at MISS. REv. CODE ch. LXI. § 17. ans. 190-93 (1857)). 
in an otherwise unfair world, lawmakers may have recoiled from the spectacle of permitting a white party to testify against a black opponent who could not speak-the Maryland-Mississippi solution. As for the Indiana solution, they may have seen a different problem: Under that state's law, white parties had the right to testify unless their opponent happened to be nonwhite. Perhaps the image of a world in which white parties could testify against white adversaries but must sit silently when facing black adversaries was too discordant for Southern tastes.

Unfortunately, I have found no contemporary commentary bearing on these issues. Still, the circumstantial case points strongly toward this conclusion: In those states that maintained racial exclusion laws, legislators chose to avoid an awkward clash between those laws and rules permitting testimony by civil parties simply by resisting the latter as long as they retained the former. Once those states abolished their racial exclusion laws in the wake of the Northern victory, there was no longer reason to resist the transatlantic trend toward testimony by civil parties. In fact, once those states abolished their racial exclusion laws, they had an affirmative reason to permit civil parties to testify - and to do so quickly. This may explain the legislative actions of the first group of states in Table 3. We will return to that twist in the story in the next section, for it helps to explain why South Carolina was the only Southern state to permit criminal defendants to testify in the 1860 s.

\section{The Link to African Americans' Right To Testify: Criminal Defendants}

The question we have just addressed is why the South lagged behind the North in abolishing the old bar against testimony by civil parties. In a sense, by using England as the standard for when this change "should" have happened, we can ask why the North was "on time" while the South was "late." But when we turn to those state laws that, beginning in 1864, gave criminal defendants the right to testify, we must ask why the North was "early"-for the English did not make this change until 1898. ${ }^{461}$ Again, I suggest we might find the answer in the racial exclusion laws of the South.

The earliest hint that the South's refusal to let nonwhites testify might have something to do with the North's seemingly disconnected decision to let criminal defendants testify appears in the appendix to John Appleton's 1860 Treatise on the Law of Evidence. ${ }^{462}$ Appleton had, as I have said, ${ }^{463}$ merely gathered together in this treatise essays he had published separately many years earlier. To these, he now added a largely unrelated appendix on the exclusion of nonwhite witnesses, which he condemned as "disastrous" and

461. See supra note 408 and accompanying text.

462. APPLETON, supra note 401.

463. See supra text accompanying note 436 . 
"enormous." racial exclusion laws sounded much like the arguments he made over and over again in the body of the treatise attacking, in succession, all of the old competency rules: As civilization progresses, "It is seen that the credit of witnesses can be more satisfactorily determined after than before a hearing. All are received as witnesses, and the various corroborating and discrediting circumstances are weighed and considered." stake his opposition to racial competency rules on general principles that he made it a point to preface his argument with the concession that the rightfulness of slavery "may . . . be fully admitted." "As

The inability of African Americans to testify in Southern law courts would shortly become one of the preeminent political issues of the day. Only the questions of black suffrage and of slavery itself generated more tension between North and South during the closing years of the Civil War and the first several years of the Reconstruction era. The strategy at which Appleton hinted in his appendix - to attack racial competency rules on the same terms as all other competency rules-soon found favor in the North. It is unclear why Northerners shunned the more obvious strategy of attacking the Southern racial exclusions as racist. Perhaps Northern politicians feared offending those border and Northern states that still maintained such laws. Or perhaps Northerners had their own doubts, founded in their own well-documented racism, ${ }^{467}$ about whether nonwhite witnesses were fully as credible as whites. In any event, they argued that, like all other once-disfavored classes of witnesses (interested persons, felons, atheists), nonwhites should be permitted to testify, and juries should be permitted to assess their credibility one by one.

But that argument pointed North as well as South. By staking the case against racial exclusion laws on general principles, Northerners exposed themselves to the countercharge of hypocrisy should they be caught harboring any of the old competency rules. The North proved to be intensely sensitive to the charge of hypocrisy, whether made by Southern forces or, as was often the case, from within its own ranks. ${ }^{468}$ It chose to abandon the last of its old

464. APPLETON, supra note 401 , at 27.

465. Id. at 272 .

466. Id. at 271 .

467. See JAMES D. BILOTTA, RACE AND THE RISE OF THE REPL'bliCAN PARTY. 18-48-1865, al 4-47.63 (1992); GEORGE M. FREDRICKSON, THE ARROGANCE OF RACE. HISTORICAL PERSPECTIVES OV SLAVERY, RACISM, AND SOCIAL INEQUALITY 44-46 (1988). In the Indiana legislature in 1865. both opponents and proponents of a bill to abolish that state's racial exclusion law pul in frank terms thetr belief in black inferiority. See 8 BREvIER LEG. REP. (Ind.) (Drapier \& Drapter) 148-49, 282-84 (1866)

468. In the first years after the Civil War, for example. some Southern whites justufied their stales" new, restrictive labor legislation by pointing out that the Union army and Freedmen's Bureau had similar labor regulations and that Norhern vagrancy laws someumes had similar impact. Southem whites noted, too, that Northem blacks often could not serve on juries, join militas, or attend public schools See ERIC FONER, RECONSTRUCTION: AMERICA'S UNFINISHED REVOLLTION 1863-1877, at 208 (1988) Dunng wartime congressional debates, there was of course no one to speak for the dexp South Senators and Representatives from border and Northem states, however, often noted their colleagues' hypocritucal 
competency rules rather than to bear the risk of that accusation. In the pages ahead, as I trace the course of the Northern attack on Southern racial exclusion rules, I will pay particular attention to this dynamic of charge and countercharge. The North-South battle over the issue of black testimony laws was waged in three major campaigns: in 1862, 1864, and 1866. We will see that the countercharge of hypocrisy was made at almost the earliest opportunity.

\section{The Campaign of 1862}

When Senator Charles Sumner of Massachusetts first took up the fight against Southern black testimony laws in 1862, he lacked modern constitutional weaponry. Congress as yet had no power to outlaw race-based evidence rules in state courts. Sumner launched his campaign instead at the seat of federal power, the District of Columbia, and at first achieved modest success. On two successive bills that proposed to free slaves in the District, Sumner offered and won amendments that provided, first, that proceedings under the Act shall be held "without the exclusion of any witness on account of color" District of Columbia there shall be no exclusion of any witness on account of color." ${ }^{270}$ Sumner also attacked the practice by which federal courts sitting in Southern states adopted the host state's exclusion of black witnesses. Here he met repeated defeats-first on June $28,{ }^{471}$ then on July $3{ }^{472}$

Sumner's third sally merits closer attention. On July 15 Sumner moved to add the provision that "there shall be no exclusion of any witness on account of color" to a bill that made other adjustments to the rules governing witness competency in federal courts. ${ }^{473}$ Immediately we see the rhetorical dynamic I described earlier: Northerners shunned the accusation of racism in favor of

stances. See, e.g., CONG. GLOBE, 37th Cong., 2d Sess. 3355-57 (statement of Sen. Foster of Connecticut); see also infra notes $478-480$ and accompanying text (discussing Foster's argument).

469. An Act for the Release of Certain Persons Held to Service or Labor in the District of Columbia, ch. 54, 12 Stat. 377 (1862). Sumner proposed the amendment on April 3. See CONG. GLOBE, 37th Cong.. 2d Sess. 1518 (1862). The amendment passed the Senate, see id., as did the bill, see id. at 1526. President Lincoln signed the bill into law on April 16. See id. at 1680, 1686.

470. CONG. GlobE, 37th Cong., 2d Sess. 3138 (1862); see also An Act Supplementary to the "Act for the Release of Certain Persons Held to Service or Labor in the District of Columbia," ch. 155, 12 Stat. 538,539 (1862).

471. Sumner offered to amend a bill that would free the slaves held by Southern rebels to provide that "in all proceedings under this act there shall be no exclusion of any witness on account of color." CoNG. GLOBE, 37th Cong., 2d Sess. 2995 (1862). His amendment failed by a vote of 14 to 25 . See id.

472. Sumner attempted to amend a proposal to alter the rule of decision in common law and equity actions in federal courts to forbid "exclusion of any witness on account of color." Id. at 3098-99. He lost, 14 to 21. See id. Even after the vote, debate continued. See id. at 3099-101.

473. See id. at 3354. The bill made state law the rule of decision regarding witness compctency in federal equity and admiralty trials-a principle that already governed in common law trials in federal courts. See id. It became law on July 16, 1862. See An Act in Relation to the Competency of Witnesses, and for Other Purposes, ch. 189, 12 Stat. 588, 588-89 (1862). 
general principles of evidence law. By so doing, however, they exposed themselves to the countercharge of hypocrisy. Standing in favor of Sumner's amendment, Senator Wilkinson of Minnesota employed the same reasoning that Jeremy Bentham and John Appleton had directed at the whole scheme of competency rules:

I do not see, and I never have been able to understand, why a court should exclude any person from testifying. The object of testimony in a court is to arrive at the truth. Now, in the State of Minnesota the plaintiff in a suit, and the defendant, and everybody, may testify, and there is no reason why all intelligent persons should not be permitted to testify in court. The object of testimony is to arrive at the truth, to arrive at the facts, and there is no earthly reason why a negro, if he knows the facts, should not be permitted in a court of justice to testify to them. I base my support of this proposition of the Senator from Massachusetts upon the simple question of justice, of arriving at the facts. The question of slavery has nothing to do with it, as I understand ....

Now, sir, the true rule is not to exclude men, but to allow the jury to determine upon the credibility of the witness. ${ }^{474}$

Wilkinson showed his facility with the jargon of evidence theorists by adding. "in regard to the question of the admission of the testimony of a negro, it is a question of credibility, and not a question of competency." later, Sumner echoed Wilkinson's reasoning, ${ }^{576}$ as did Senator Howard of Michigan. ${ }^{477}$

After Wilkinson thus staked the defense of Sumner's amendment on general principles independent of race, Senator Foster of Connecticut moved to exploit the Northern weakness that Wilkinson unwittingly had exposed. As sponsor of earlier legislation that Sumner had burdened with an amendment to permit testimony by nonwhites, Foster perhaps was annoyed at Sumner's

474. CONG. GLOBE, 37th Cong., 2d Sess. 3355 (1862).

475. Id. at 3356 .

476. Sumner said:

Make any objection that you please to the credibility of a witness: show that he is not intelligent, that he is not worthy of belief, that his character is bad, and make all proper deductions from his testimony on this account; but do not say that he is absolutely incompetent: that he cannot be heard in court: that no matter how intelligent. Inuthful. of respectable he may be, he cannot be admitted to testify if he happens to be black. Such an exclusion of iesimony is cruel to the witness, degrading to courts which admınister such a rule, and destrucuve of Id. justice, which requires evidence from every quarter.

477. Howard phrased the point this way:

When a negro is offered as a witness in court, the question should not be respecting his admissibility as a witness, but as to the weight to be given to his lestlmony. Let him stand upon Id. at 3357. precisely the same basis as to credit that other persons stand in the same court 
tactics. ${ }^{478}$ Though he professed to favor the testimony of blacks, ${ }^{479}$ he pointed up the hypocrisy in Wilkinson's reasoning. Foster demanded to know of Wilkinson whether in Minnesota atheists are permitted to testify. When Wilkinson said they were, Foster quickly took new aim:

In most of the States, I think, the belief in the existence of God is required in order that a man shall be admitted as a competent witness in a court of justice. I am pretty sure it is so in the State of the honorable Senator from Massachusetts; and that that law has been administered there within a few years past, even in a capital cause. It was asserted that a man who was charged with a capital offense, murder I think, escaped conviction because the person who saw the deed committed was a man who either did not believe in the existence of God, or who lacked that religious faith which by the law of Massachusetts was requisite in order to make a man a competent witness in a court of justice; the honorable Senator will correct me if I am wrong; . . . I I am quite sure the law of Massachusetts does not allow an atheist to testify. ${ }^{480}$

Although Foster was wrong (Massachusetts had permitted atheists to testify since 1860), ${ }^{481}$ Sumner did not correct him. Sumner's proposal was again defeated: yeas 14 , nays $23^{482}$

\section{The Campaign of 1864}

In June 1862, before the final defeat of Sumner's proposal, John Appleton had written to Sumner to offer his encouragement. Appleton declared himself "half inclined" to write a small publication attacking racial competency rules, the "monstrous absurdity of [which] ... when fully set forth would even astonish [their] own advocates." 483 Appleton did not write his tract then,

478. Introducing the Rules of Decision Bill on July 3, Foster said without prophecy, "It is a little bill ... . which I think will not occupy time or create division." Id. at 3098. A moment later, after Sumncr proposed his amendment, Foster reconsidered: "Of course, . . . that will produce discussion and division, and defeat the bill ...." Id. Sumner's amendment to this legislation was defeated. See supra note 472.

479. Foster noted his own professional experience:

But when [Sumner] speaks of my "favorite rule of exclusion," as though I was opposed to having black men testify, I would say that, in the course of my professional life, I presume I have examined more black men as witnesses than he ever did white ones, and did it, 1 hope, courteously, without a thought that I was not getting the truth in the majority of cases. Id. at 3357.

480. Id. at 3355 .

481. See MASS. GEN. LAwS ch. $131, \S 12$ (1860) ("Every person not a believer in any religion shall be required to testify truly under the pains and penaities of perjury; and the evidence of such person's disbelief in the existence of God may be received to affect his credibility as a witness."). Foster was not way off mark. As late as 1854 the Massachusetts high court had restated the incompetency of atheists. See Commonwealth v. Smith, 68 Mass. (2 Gray) 516, 516 (1854). But see Hunscom v. Hunscom, 15 Mass. (14 Tyng) 184, 184 (1818) (holding that a witness's atheism went only to credibility, not to competency).

482. See CONG. GloBE, 37th Cong., 2d Sess. 3358 (1862).

483. Letter from John Appleton to Sen. Charles Sumner (June 25, 1862), microformed on Sumner 
however, and for about a year and a half, little was heard from either man on the subject. Late in 1863, Appleton raised the issue again: "I believe you have not by act of Congress removed the disability of black men as witnesses-If not done, and [if] I have leisure I shall be half inclined to write a letter on the subject ...." the topic in earnest. Appleton wrote his promised "letter"-38 handwritten pages $^{485}$-and sent it to Sumner with the suggestion that "[i]t is as long as a reasonable speech in Congress." 486 But Sumner had written his own dissertation on the topic ${ }^{487}$-arguably a more scholarly treatment than Appleton's. With a brief nod to his supporter from Maine, ${ }^{\text {sss }}$ he merely appended Appleton's work to his own.

Although both Appleton and Sumner condemned the exclusion of nonwhites as racist, ${ }^{489}$ both also attacked the exclusionary laws as a violation of modern evidence theory, which rejected all competency rules. Appleton said flatly that "[t]he exclusion of testimony from whatsoever source attainable is presumably wrong." 490 Sumner wrote that racial exclusions may "be treated as belonging to that system of evidence which, in defiance of reason, undertook to declare in advance that certain classes of witnesses were incompetent to testify .... The whole system of exclusion was covered with ridicule by Jeremy Bentham, who exposed its irrational character."int

Congressional supporters of 1864 legislation to roll back racial competency rules likewise grounded their support in general principles of evidence law.

Papers, Reel 26. No. 82 (Chadwyck-Healy Inc.). David Gold discusses the Sumner-Appleton correspondence in detail in his excellent biography of Appleton See Go1.D, supra note 429. at 11 (1.11

484. Letter from John Appleton to Sen. Charles Sumner 2.3 (Oct 10. 1863). microfornted on Sumner Papers, Reel 29, No. 363 (Chadwick-Healy Inc.).

485. See Letter from John Appleton to Sen. Charles Sumner (Jan 24. 186-1), mocroformed on Sumner Papers, Reel 30, No. 261 (Chadwick-Healy Inc.); see also S. REP No 38-25. at 18-23 (1.364), microformed on Sumner Papers, Reel 77. No. 597 (Chadwick-Healy Inc.)

486. Letter from John Appleton to Sen. Charles Sumner (Jan 1. 1864). microformed on Surnner Papers, Reel 30, No. 151 (Chadwick-Healy Inc.).

487. See Senate Comm. ON Slavery \& Freedmex, 38Th CONG. EXcll sios of Wimesses ov ACCOUNT OF COLOR (Comm. Print. 1864), reprinted in 8 WORKS OF CHARLES ST MIVER 176 iBoston, Lec \& Shepard 1874).

488. Sumner praised the general treatment of competency rules in Appleton's evidence trealise and called Appleton a "distinguished authority on the exclusion of colored testumon! "Id. reprinted in 8 WORKS OF CHARLES SUMNER, supra note 487 , at 201 \& n ?

489. See, e.g., id., reprinted in 8 WORKS OF CHARLES SLMNER, supra note 487. at 203 icompanng these laws to the persecution of the Moors in Spain and of the Jess in many counines and to india's caste system); Letter from John Appleton to Sen. Charles Sumner. supra note 485. at 37 (ndiculing the notion that "the Almighty had so failed as to have created whole races of men so untrustw orthy that tt would be unsafe even to hear their testimony").

490. Letter from John Appleton to Sen. Charles Sumner, supra note 485 (manuseript at it)

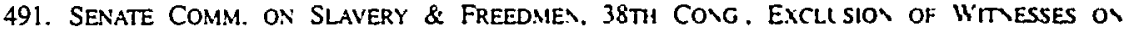
ACCOUNT OF COLOR (COmm. Print. 1864), (cItation omilled) reprinted in 8 WORKS OF CHARLES SL MVER. supra note 487 , at 201 . 
Senator Collamer, who introduced the year's first legislation on the topic, ${ }^{492}$ defended it in such terms:

[T] he general practice and the tendency of opinion now is to take away all disqualification of witnesses upon any ground, and to leave their testimony to go to the jury and the court for them to weigh it and do justice. In many of our States now, even the parties to an action are competent witnesses; and no objection in point of law exists in nearly all the States on account of a man's religious sentiments. All those disqualifications have been swept away, and we think it time to do it here in relation to colored people, and to make them competent witnesses in the United States courts. The courts and the juries of course will judge of their credibility. ${ }^{493}$

With Collamer's legislation pending, Sumner once again moved to amend an unrelated bill by adding a provision "[t]hat in the courts of the United States there shall be no exclusion of any witness on account of color." ${ }^{494} \mathrm{He}$ made the now familiar argument that the exclusion of blacks should go the way of other testimonial exclusions. ${ }^{495}$

Sumner's reassertion that the issue was not race but evidence law prompted Senator Buckalew of Pennsylvania to the floor: "As this is a proposition in relation to the laws of evidence, I offer an amendment to cover the whole subject; I move to add, 'or because he is a party to or interested in the issue tried." 496 Perhaps out of malice toward Sumner's amendment, Buckalew sought to attach to it a much broader reform: the qualification of both civil parties and criminal defendants in the federal courts. Sumner naturally did not want to see his own reform burdened, but found himself trapped by his own tactics:

Mr. SUMNER. I am in favor of that proposition taken by itself, but I do not wish to see it put upon this.

492. Collamer's legislation aimed primarily at abolishing the prohibition against black mail carricrs. Because, he claimed, it would be dangerous to have mail carriers who were disabled from testifying against mail thieves, his legislation provided generally "[t]hat in the courts of the United States there shall be no exclusion of any witness on account of color." CONG. GlOBE, 38th Cong., Ist Sess. 837 (1864).

493. Id.

494. Id. at 3259.

495. See id. at 3260 ("Let the witness be admitted always to testify, leaving the jury to be the judges of his credibility."). Senator Howard of Michigan spoke in similar terms:

The general principle is that every person may be used as a witness who has arrived at years of discretion....

... I will put the case upon the same ground upon which the case of every white witness is placed by the common law; and that is that the jury, if the case be one before a jury, is to judge of the credibility of the witness and of the amount of credit to be given to his wholc story.

Id. at 3261 .

496. Id. at 3260-6I. 
Mr. BROWN, (to Mr. Sumner.) That is just what other people say about yours. [Laughter.]

Mr. SUMNER. I understand that, but I wish to secure this justice.

Mr. BUCKALEW. I wish to secure the additional justice provided by my amendment. ${ }^{497}$

On the unexplained suggestion of Senator Wilkinson, ${ }^{498}$ Buckalew quickly agreed to restrict his amendment to civil parties only. ${ }^{499}$ As it would happen. criminal defendants would not win the right to testify under oath in federal courts until $1878 .^{500}$ But the balance of Buckalew's proposal passed, ${ }^{501}$ as did Sumner's amendment to which Buckalew's was attached (Buckalew voting no), ${ }^{502}$ as did the underlying legislation. ${ }^{503}$

Hence civil parties won the right to testify in federal court as a direct consequence of Charles Sumner's struggle to end the exclusion of black witnesses in federal courts sitting in Southern states. Senator Buckalew exploited the weakness in the rhetorical strategy of Sumner and his confederates: If "the general practice and the tendency of opinion now is to take away all disqualification of witnesses upon any ground," as Senator Collamer claimed that it was, ${ }^{504}$ then the exclusion of civil parties-indeed of almost any witness-must end. The Senate did not then carry such reasoning through to its logical conclusion by permitting criminal defendants to testify. The absence of debate on this issue can leave us with no conclusion but that the notion of testimony by criminal defendants struck many in the Senate as a more radical innovation still than the testimony of civil parties-more so even than the testimony of black witnesses in Southern courts.

Yet Maine acted that same spring to permit testimony by criminal defendants. $^{505}$ I cannot prove that Maine's first-in-the-nation defendant testimony law responded in any direct way to the debate then raging in Congress about racial exclusions. On the one hand, Maine surely would soon

497. Id. at 3261 .

498. Wilkinson said merely:

If the Senator from Pennsylvania will modify his amendment so as to have $\|$ apply only to civil actions. I will vote for it. I cannot vote for a proposstion to allow a panty charged with counterfeiting in a criminal action, or any other felony. to be a witness in his own case; but if he will confine his amendment to civil actions I will vote for the proposition. for I am in favor Id. generally of parties testifying in cours.

499. See id. Senator Carlile objected to the modification-agann without explanation. See id.

500. See Act of Mar. 16, 1878, ch. 37. 20 Stat. 30 (codified at 18 U.S.C. $\$ 3481$ (1994))

501. See CONG. GlobE, 38th Cong., Ist Sess. 3261 (1864).

502. See id.

503. See An Act Making Appropriations for Sundry Civil Expenses of the Government for the Year Ending the Thirieth of June, Eighteen Hundred and Sixty-Five. and for Other Purposes, ch $210 . \$ 3.13$ Stat. 344, 345 (1865).

504. CONG. GLOBE, 38th Cong., Ist Sess. 837 (1864); supra text accompanying note 493.

505. See supra Table 1. 
have adopted a law to permit defendant testimony. Already in 1859 it had permitted persons charged with certain minor crimes to testify at trial. ${ }^{306}$ Although I have not found any useful commentary on this earlier law, the most natural inference is that it served as a trial run for the later, broader law. Appleton, then a justice on the state's supreme judicial court, would be elevated to chief justice in $1862,{ }^{507}$ perhaps gaining the additional clout he needed to finish the reform he had sought for thirty years. Appleton openly advocated for the 1864 legislation, ${ }^{508}$ and he was the only authority the judiciary committee of the Maine Senate cited in recommending its passage. ${ }^{509}$

On the other hand, one cannot but wonder at the timing of the law change and at other circumstances hinting at a connection with events in Washington. In late January 1864 , Appleton contributed a weighty manuscript to Sumner's campaign against the Southern racial exclusion laws. ${ }^{510}$ Less than two weeks later, an ardently Unionist legislator from Appleton's own community-one Lewis Barker-introduced the Maine legislation that would permit criminal defendants to testify. ${ }^{511}$ I have found no recorded debate on the proposed legislation, no public commentary, and no private correspondence among the parties that might shed light on the reasons for the bill's passage or its introduction in this particular legislative session. I can only speculate that Appleton might have confronted legislators with the proposition that Maine's failure to permit criminal defendants to testify, in violation of the general principles of evidence law that Appleton had preached for decades, could expose Sumner and his cause to the charge of hypocrisy. Had Appleton pitched the defendant testimony law in these terms, ${ }^{512}$ the Maine legislature no doubt

506. See An Act Relating to Witnesses and Evidence, ch. 104, 1859 Me. Laws 97, 97 (extending the testimonial right to persons charged with libel, nuisance, simple assault, assault and battery, or the violation of any municipal or police ordinance).

507. See GOLD, supra note 429 , at 35.

508. In 1866 Appleton wrote to John Quincy Adams II of the Massachusetts House: "I had no doubt that the interests of justice required that the [1864 law change in Maine] should be made, and so far as I had any influence, freely used it in favor of its adoption." Letter from John Appleton to Rep. John Quincy Adams (Feb. 24, 1866), in H.R. 361, Ist Legis. Sess. 7 (Mass. 1866).

509. See S. 43-15, Ist Legis. Sess. 2 (Me. 1864).

510. See supra notes $485-486$ and accompanying text.

511. Barker introduced the legislation on February 5. See 43 J. H.R., STATE ME. 199-200 (Fcb. 5, 1864). Barker was from Stetson, a town not far from Appleton's Bangor in Penobscot County. See DOCUMENTS PRINTEd by ORDER OF THE LEGISLATURE OF THE STATE OF MAINE 225 (Augusta, Stevens \& Sayward 1864). He was a Union Party member, see id. at 228 , and traveled nationaliy to speak in support of the war effort, see A.W. Paine, Address in Bangor, Me. (Oct. 31, 1890), in IN MEMORIAM: LEWIS BARKER (n.p., 1890) (unpaginated document).

512. Had he made such a pitch, it might have explained the oddly slave-like imagery that Barker used when he announced the bill's passage to Appleton with a triumphant telegram: "The bill has passed. I thank God that the padlock has been removed from the lips and that citizens accused of crime may hereafter testify in their own behalf." Charles Hamlin, John Appleton, in 5 GREAT AMERICAN LAWYERS 41, 50 (William Draper Lewis ed., 1908) (quoting Barker's telegram). 
would have been receptive: It had proved to be one of the most militantly pro-black state legislatures in the country. ${ }^{513}$

For all the evidence shows, Maine permitted criminal defendants to testify in 1864 because Appleton's Benthamite reasoning finally triumphed in legislative minds. Appleton's influence cannot, however, explain the stark, indeed nearly perfect North-South split between those states that chose to follow Maine's lead in the next few years and those that did not. To expose other forces at work, we will need to look closely at those Northern states that gave defendants the right to testify-I will look hardest at Massachusetts-and at the one Southern state that seemingly broke ranks to permit defendants to testify-South Carolina. Only very close scrutiny can avail us, because the issue of defendant testimony (unlike that of black testimony) rarely disturbed the public consciousness. We must hunt for the small shards of evidence thrown off when minor legislation explodes in the midst of general warfare.

\section{The Campaign of 1866}

\section{a. Massachusetts}

Sumner's successful 1864 amendment to an appropriations act secured the right of nonwhites to testify in federal cour. In the absence of any perceived federal power to dictate evidence rules in the state courts, that was as much as Congress could then do. The North's victory the following year, however, put it in the position to dictate the terms of readmission to the Union and of the withdrawal of federal forces. There was little debate about whether repudiation of slavery should be among those terms. After Tennessee acted quickly to ratify the Thirteenth Amendment, most of the South abandoned any hope of retaining slavery. There was, in contrast, scarcely any question of making black suffrage a condition for readmission. Although the most radical of Northern voices called for giving newly freed slaves the vote, support for universal suffrage even in the North fell far short of a critical mass. Between these two issues lay the question of granting freedmen the right to testify in state courts of the South. For a season, it ranked among the most hotly contested political issues in the nation.

513. In 1855, Maine enacted a personal liberty law that forbade official participation in prosecutions under the Fugitive Slave Act. See GoLD, supra note 429. at 104. In 1857, the Iegislature declared the Supreme Court's Dred Scott decision to be "not binding in law or conscience." Id. at 100 The Senate asked the supreme judicial cour to decide whether Maine's Afncan Amencan residents were L'S citizens and hence entitled to vote. The result was never in doubt: The cour ruled affimalively with a single dissent. See Opinions of the Justices, $44 \mathrm{Me} .505$ (1857). Appleton voted with the majonty and authored a long separate opinion. See id. at 521 (Appleton. J.. concumng). 
A quick glance at any major Northern newspaper during the fall of 1865 reveals the intensity of Northern concern about the right of blacks to testify. ${ }^{514}$ Hardly a day passed without news or commentary on the progress that one or another Southern legislature had made toward full participation by freedmen in the courts. ${ }^{515}$ Officials of the Union Army, claiming they spoke for the President, declared that Freedmen's Courts would not surrender jurisdiction to civil authorities until Southern states made blacks competent to testify. ${ }^{516}$

By and large, Southern states did what they had to do to rid themselves of the Freedmen's Courts, though they did no more. Only four Southern states-Arkansas, ${ }^{517}$ Louisiana, ${ }^{518}$ South Carolina, ${ }^{519}$ and Tennessee ${ }^{520}$ -removed all distinctions of color from the qualification of witnesses during the 1860s. Each of the rest granted blacks the right to testify only in those cases in which a black person was a party or, in a criminal case, the victim. ${ }^{521}$ That is, an African American person who happened to witness a crime by a white person or a civil dispute between two white persons remained

514. See, e.g., The Progress of Reconstruction, N.Y. TIMES, Oct. 3, 1865, at 4. As the Times wrotc: [T]he denial of the suffrage will not, of itself, be a fatal objection [to the readmission of Southern states].

But the denial to the freedman of the power to testify in court against the white man, we believe, would be a fatal objection. It strikes not at a mere civil franchise, but at a natural right- the right of protecting life and property. When a white man may take a freedman's lifo or property with impunity, if no other white men be present, the freedman has no security for either. We believe that the government would be bound to consider the continuance of that monstrous feature of the black code as proof positive of a design to make the freedman still a victim of all practicable injustice and oppression, and therefore proof positive of the unfitness of the southern states to be restored to their old power.

Id.; see also The President's Policy, and the Opposition, N.Y. TIMES, Oct. 11, 1865, at 4 ("It is impossible to urge a respectable reason for this miserable attempt to deny the freedmen the right to appear as witnesses before legal tribunals. Its only possible motive is a desire to keep the freedmen down to their old cattle level.").

515. In October 1865, when Northern concern with the problem of racial exclusion laws was quitc high, the New York Daily Tribune mentioned the issue at least 21 times, the New York Herald at least 12 times, the New York Times at least 11 times, and the Springfield Republican at least 16 times.

516. See Freedmen's Affairs in Mississippi, SPRINGFIELD REPUBLICAN (Mass.), Oct. 6, 1865, at 3; Matters in South Carolina, SPRINGFIELD REPUBLICAN (Mass.), Oct. 26, 1865, at 2; The Tennessee Freedmen, SPRINGFIELD REPUBLICAN (Mass.), Dec. 18, 1865, at 2; The Virginia Legislature, SPRINGFIELD REPUBLICAN (Mass.), Dec. 18, 1865, at 2.

517. See An Act To Declare the Rights of Persons of African Descent, No. 35, § 1, 1867 Ark. Acts 98.

518. See An Act To Amend and Re-Enact Article Twenty-Two Hundred and Sixty-One of the Civil Code of the State of Louisiana, No. 70, $\$ 1,1867$ La. Acts 141, 143.

519. See infra notes 554-563 and accompanying text.

520. See An Act To Do Justice and Render Persons of African and Indian Descent Competent Witnesses in the Courts of this State, ch. XVIII, 1866 Tenn. Acts 24, 24 (making blacks competent "[because] such persons are by an act of Congress competent witnesses").

521. See, e.g., TEX. CONST. of 1866, art. VIII, $\S 2$, reprinted in 1866 TEX. GEN. LAWS 881; An Act To Protect Freedmen in Their Rights of Person and Property in This State, No. 86, § 1, 1866 Ala. Acts 98, 98 (adopted Dec. 9, 1865); Act of Dec. 15, 1865, tit. XXXI, No. 251, $§ 1,1866$ Ga. Acts 239, 239; An Act To Confer Civil Rights on Freedmen, and for Other Purposes, ch. IV, 1866 Miss. Laws 82; An Act Concerning Negroes and Persons of Color or of Mixed Blood, ch. 40, $§ 9,1866$ N.C. Pub. Laws 99, 102 (providing the text of an act passed on March 10, 1866); An Act in Relation to the Testimony of Colored Persons, ch. 24, 1866 Va. Acts 89, 89-90. 
incompetent to testify. Moreover, several Southern states refused to permit blacks to testify by deposition or sworn affidavit - a privilege they sometimes extended to whites. ${ }^{52}$ The point of this restriction, as the legislature of Florida made clear, ${ }^{523}$ was to ensure that no white Southern jury (and the juries would remain white for the time being) would mistakenly give a black affiant the credit they reserved for whites. Most strikingly, the North Carolina law required that "whenever a person of color shall be examined as a witness, the court shall warn the witness to declare the truth." President seemed content with the halfway measures taken by most Southern states, some of the more perceptive Northern newspapers, including Horace Greeley's New York Tribune, demanded purer equality for black witnesses. ${ }^{\text {s2 }}$

As controversy churned over the right of freedmen to testify, a different issue suddenly seized the North in a fit of self-accusation. On October 2, 1865 , Connecticut voters rejected a free suffrage referendum, and the liberal Northern press announced that such Northern hypocrisy would undermine the cause of suffrage everywhere. In Boston, the Daily Advertiser lamented:

[I]t is not unlikely to have an adverse moral effect . . . that a New England State has declined a system which New England is somewhat forward in urging as the general rule for reconstruction at the South. ... [A]ny reluctant Carolinian or Mississippian may fairly reply to us, - why require impartial suffrage at the South, when Northern States have not only neglected to adopt it, but in the marked instance of a New England State have rejected it $?^{526}$

Greeley's Tribune added with somewhat more bile:

Connecticut must surely feel proud of the laudations heaped on her for her recent vote by every still rancorous Rebel in the land. The

522. See, e.g., TEX. CONST. of 1866 art. VIII, § 2, reprinted in 1866 TEX. GEN. LAws 881: No. 86. 1866 Ala. Acts 98; Ch. 4, 1865 Miss. Laws 82: Ch. 24, 1866 Va. Acts 89.

523. See An Act Concerning Testimony, ch. 1472, 1865 Fla. Laws 35, $35-36$ (forbudding blacks to testify by deposition "otherwise than in such manner as will enable the court or jury to judge of the credibility of the witness").

524. Ch. $40, \S 10,1866$ N.C. Pub. Laws Stat. 99. 102.

525. See, e.g., Civil Rights, N.Y. Dally TR1B., Mar. I. 1866. al 4. As the Tribune wrote:

We believe no single Southern State has yet enabled Blacks to sue and be sued. to give testimony and rebut testimony, on equal terms with Whites. . . What can be more absurd than to provide that a Black may testify in cases between Blacks and Whites. but not when the parties are both White? If he would ever swear falsely, would he not be likely to do so in a case between a White and a Black? And, if his oath can be taken in cases where he will naturally have bias, why not in cases where he is likely to have none?

Id.; see also, e.g., The Freedmen's Bureau Bill, BURLINGTON Free Press (Vt.). Jan. 26. 1866. at 2 ('This is not the most liberal concession of equal rights conceivable, inasmuch as the colored man is permitted to testify personally or by affidavit only in cases to which colored persons are paries."): Lberny and Equality in Virginia, SPRingfield Republican (Mass.). Apr. 17, 1866, at 2 (calling Virginia's refusal to permit blacks to testify in cases between two whites "ridiculous").

526. BOSTON DAILY ADVERTISER, Oct. 4, 1865, at 2. The Advertiser wient on to argue gamely that there are stronger reasons to insist on universal suffrage in the South than in Connecucut. See id. 
Montgomery Mail (Alabama) construes that vote to foreshadow the expatriation of all Colored Americans from the land of their birth . . . : “. . . Connecticut says [the Negro] is not wanted here, and for once Connecticut is right."

Months later, Massachusetts Governor John Andrew attacked Charles Sumner's plan for counting only those blacks who could vote when determining Southern representation in Congress. Andrew worried that the denial of black suffrage by Connecticut (and by Wisconsin as well) would expose Sumner to Southern charges of hypocrisy. ${ }^{528}$

Such freely flowing self-accusations make it plain that even in victory the North felt it had to live by the rules it sought to impose on the South. ${ }^{529}$ Two weeks after the Connecticut vote, a perceptive Boston lawyer took advantage of this mood of guilty self-examination to argue that the North had to guard against the charge of hypocrisy in the context of testimonial exclusions as well. The lawyer, Frederic William Sawyer, was a frequent contributor to the Boston Daily Evening Transcript, ${ }^{530}$ an influential newspaper that previously had supported the right of criminal defendants to

527. N.Y. DAlLY TRIB., Oct. 14, 1865, at 4; see also Connecticut Against Equal Suffrage, SPRINGFIELD REPUBLICAN (Mass.), Oct. 4, 1865, at 4 ("Nor would it be less preposterous to say to southern men that we cannot trust them to do justice to the freed negroes unless they can protect themselves by the ballot. while we can trust ourselves to do justice to our own colored citizens without that protection.").

528. See David Donald, Charles Sumner AND the RightS of MAN 244-45 (1970).

529. Indiana Governor Oliver Morton put the Northem sensibility this way in an 1865 speech:

Let me inquire for a single moment, in what condition is Indiana to urge negro suffrage in

South Carolina, or in any other State? . . . We not only exclude them from voting, we exclude them from testifying in the courts of justice. We exclude them from our public schools, and we make it unlawful and a crime for them to come into the State of Indiana at any time subsequent to 1850 ... . [W]ith what face, I say, can Indiana go to Congress and insist upon giving the right of suffrage to the negroes in the Southem States? If her Congressmen asked to do this, they will naturally be asked in turn, what have you done with these people in your own state? Speech of Governor Morton, printed in Reconstruction and Negro Suffrage, INDIANAPOLIS DAlLY J., Oct. 2, 1865, at 2; see also New York and the Suffrage Question, SPRINGFIELD REPUBliCAN (Mass.), Scpt. 6, 1865 , at 4 ("[Republican party] leaders did not dare propose to give political equality to the colored men of Ohio, and they were thus estopped from demanding the enfranchisement of the freedmen of the South; for how could they ask the late slaveholders to give the ballot to the ignorant freedmen while they themselves still withhold it from their own intelligent colored citizens?"); SPRINGFIELD REPUBLICAN (Mass.), Nov. 14, 1865, at 2 (editorializing in similar fashion about inequalities in the laws of Wisconsin. Minnesota, New York, and Ohio).

530. The correspondence, quoted infra text accompanying note 532, is signed merely "Carl." William Cushing identified "Carl" as Sawyer and noted that he was a "regular contributor" to the Transcript beginning in 1847. WILliam CUSHING, INITIALS AND PSEUdONYMS: A Dictionary OF Literary Disguises 50 (London, Thomas Y. Crowell \& Co. 1886). Sawyer practiced law in Boston from 1840 until his death in 1875. See 5 APPLETON's CYCLOPFDIA OF AMERICAN BIOGRAPHY 407 (James Grant Wilson \& John Fiske eds., New York, D. Appleton \& Co. 1888). I have not discovered any legal writings by him, though it appears likely that he concentrated in maritime law. In 1840, he published the Merchant's and Shipmaster's Guide, and in 1856 he wrote to Charles Sumner to lobby for reform of the maritime law, see FREDERIC WILlJAM SAWYER, THE MERChANT'S AND SHIPMASTER'S GuIDE (Boston, Benjamin Loring \& Co. 1840); Letter from Frederic W. Sawyer to Sen. Charles Sumner (Mar. 8, 1856), microformed on Sumner Papers, Reel 13, No. 54 (Chadwick-Healy Inc.). I am grateful to Virginia Smith of the Massachusetts Historical Society for helping me to identify "Carl." 
testify. ${ }^{531}$ Sawyer's argument appeared as the lead item on the front page of October 16,1865 . I reproduce it here nearly in full:

LIGHT IN THE COURTS OF LAW. Any one who loves justice, and believes in light, rather than darkness, will agree with the Transcript, in advocating the right of the colored men to testify in the Courts of law. There is no pretence that justice can be intelligently administered without admitting to the stand anybody and everybody of sound mind who knows anything about a given case.... For a long period we were in the same gross darkness in this matter of allowing witnesses to testify that now prevails at the South. We had our proscribed classes as well as they. Ours were shut out on account of the color of their minds, and not of their skins. If one was an infidel, or interested in the suit, or husband or wife of one of the parties, or defendant in a criminal prosecution, or a State Prison convict, he was adjudged too morally black to be believed.

We have gained ground wonderfully in the way of civilization in the last two years in those respects, but we are so little ahead of the South in the matter, that this communication is to suggest that the North and South go hand in hand in this proposed reform. That is to say, let us put our reform in black and white. When we insist, as in truth and justice we ought, that black men shall be admitted as witnesses in courts of law, let us insist that white men shall be admitted too. In our city of Boston this year, before it closes there will have been disposed of more than fifteen thousand cases where the party most interested in the case, and knowing, too, all the facts of it, has been, or will be, excluded from testifying. If this controversy over the colored man's right to testify should result in setting white men free in that particular it will do a good thing. There ought to be no restrictions whatever on the right to testify when the witness is of sound mind and sufficient age, but if there is to be any restriction it may just as well be based on the color of the skin as anything else..$^{532}$

531. On August 2, 1865, the editors of the Transcripl compared our system of criminal justice unfavorably with the French: "The French system is the natural process by which truth is reached. which is to hear both parties and let the credibility of each have its due weight in the verdict Our system shuts out what must necessarily be the only witness of a crime secrelly commited ... " Local Intelligence, BOSTON DAILY EVENING TRANSCRIPT. Aug. 2, 1865, at 4. it is unclear from the context whether these sentiments were original or reprinted from another paper.

532. Light in the Courts of Law. BOSTON Dally EVENing Transcript. Oct. 16. 1865. at 1 Alexis Haller, my research student in the summer of 1996, found this remarkable bil of evidence.

At about the time of Sawyer's publication. the New' York Times also editonalized about Southern racial exclusion laws. Although the Times did not make reference to Northern defendant testimony laws. it did state the case against racial exclusion laws in terms of the general evidence theory thal rejects all competency rules:

[I]t cannot be said that [the emancipated slave] is not qualıfied to give evidence. . . Or late years the policy of jurisprudence everywhere has been to abolısh all disqualificaltons for rendering testimony, and to let objections apply to the credibility only. Even personal interest in the case no longer excludes from the witness stand. in most legal junsdictions. The theory is, and all experience goes to confirm it. that no false testumony can stand the ordeal of a thorough cross-examination .... 
Sawyer's complaint that "the party most interested in the case, and knowing, too, all the facts of it," was excluded from testifying can be a reference only to the exclusion of defendant testimony in criminal cases, as no other broad-based exclusionary law survived in Massachusetts.

Sawyer's prophecy that "this controversy over the colored man's right to testify [might] result in setting white men free" to testify for themselves in criminal cases was no idle guess. Sawyer wrote between two sessions of the Massachusetts legislature. In the previous session, a bill to permit defendant testimony had failed despite substantial support in both houses. ${ }^{533}$ In the next session, a virtually identical bill passed into law. ${ }^{534}$ The only surviving pieces of legislative history are two judiciary committee reports that recommended passage of the bill and that appended letters from John Appleton. ${ }^{535}$ The two committee reports differed somewhat, as did the two Appleton letters, and the reports differed a little from the letters, but all four documents recite the familiar Appleton-Benthamite arguments that all competency rules frustrate a search for the truth. Although an election would soon strengthen the Republican representation in the Massachusetts House-and would give the defendant testimony law a new sponsor with a famous name, John Quincy Adams II-Sawyer knew none of that as he wrote. What he knew was that black testimony laws had become one of the most pressing social and political issues of the day.

Sawyer may have had one other piece of news in mind as he wrote. On August 31,1865, the Transcript reported the acquittal of James Williams, who had been accused of stabbing a man to death on the streets of Bangor, Maine.

The President's Policy, and the Opposition, supra note 514; see also Negro Testimony, SPRINGFIELD REPUBLICAN (Mass.), Jan. 3, 1866, at 4 (providing a similar argument).

533. The text of the 1865 bill appears in S. 195, 1st Legis. Sess. 9 (Mass. 1865): "In the trial of all criminal cases . . . it shall be the privilege of the defendant, upon his own request, but not otherwise, to be a competent witness." The Senate approved this version of the act on April 25. See 1865 MASS. SENATE J. 588 (unpublished document, on file with the Massachusetts State Library). On May 9, the House passed the bill, but with two amendments, one of which provided that "the omission of the defendant to avail himself of the privilege of so testifying, shall not be used against him, in argument or otherwise, nor create any influence to his prejudice." S. 262, 1st Legis. Sess. 2 (Mass. 1865). The Senate refused to concur in the House amendments, see 1865 MASS. SENATE J. 733 (unpublished document, on file with the Massachusetts State Library), and so the bill died.

534. On January 22, 1866, John Quincy Adams II proposed in the House that his judiciary committec take up the issue of defendant testimony. See 1866 MASS. HouSE J. 46. On May 12, the House approved a bill providing that "[i]n the trial of all ... proceedings against persons charged with the commission of crimes or offences, the person so charged shall at his own request, but not otherwise, be decmed a competent witness." An Act in Relation to Evidence in Criminal Prosecutions (unpublished document, on file with the Massachusetts Archives and with author). The Senate approved the bill on May 19, but added the words, "Nor shall the neglect or refusal to testify create any presumption against the defendant." 1866 MASS. SENATE J. 719; see The Adjournment Promised This Week, SPRINGFIEl.d REPUBLICAN (Mass.), May 21, 1866, at 4. On May 23, the House approved the Senate amendment, see 1866 MASS. HouSE J. 423; it approved the bill on May 24, see 1866 MASS. HouSE J. 428; Act of May 26, 1866, ch. 260, 1866 Mass. Acts. 245.

535. See Letter from John Appleton to Darwin E. Ware (Feb. 22, 1865), in S. 195, Gen. Ct. (Mass. 1865); Letter from John Appleton to John Quincy Adams II (Feb. 24, 1866), in H.R. 361, Gen. Ct. (Mass. 1866). 
Williams's trial had caused a sensation in Bangor, where John Appleton himself presided at the trial. ${ }^{536}$ The Boston press paid note, at least in part because Williams was among the first accused murderers to take advantage of Maine's 1864 law permitting defendant testimony. As the Transcript told it.

The remarkable simplicity and apparent truthfulness of the prisoner, his prompt and ready answers, freedom from all contradiclion and equivocation, and in fact every test of truth were so striking, that the court, jury and the crowd of listeners were all convinced that he was fully justified in the killing. Without his own testimony, however, he probably would have been severely dealt with by the law. ${ }^{537}$

I would not make much of the Williams case were it not for an odd passage in an obscure article in the 1914 edition of the Maine Law Review. The author claimed to have spoken with Albert Paine, who was a prominent member of the Maine bar in the 1860s and who himself claimed to have been the chief inspiration behind Maine's 1864 law. ${ }^{538}$ After telling of the jury's swift acquittal of Williams, the article recounted Paine's memory of what happened next:

[Williams's acquittal] caused a furor in the Boston and New York papers, and Mr. Paine was invited by one of the Adams family who was then sitting in the Massachusetts Legislature to come to Boston. He accepted the invitation, and sitting in Mr. Adam[s]'s seat while the session was in progress, wrote with his own hand the draft of the law which was passed with almost unprecedented haste .... ${ }^{539}$

There is so much of this brief passage that is exaggerated or demonstrably

536. The Bangor Daily Whig \& Courier provided detalled coverage. See Tral of James H. Willams for the Murder of James McGraw, BANGOR DAlLY WHIG \& COURIER. Aug. 22, 1865, at 3; Trual of James H. Williams for the Murder of James McGraw, BANGOR DAILY WHIG \& COURIER. Aug. 23. 1865. at 3: Trial of James $H$. Williams for the Murder of James MCGraw, BANGOR DAILY WHIG \& CouRIER. Aug. 24, 1865, at 3; Closing of the Murder Trial: Aquitral of the Prisoner. BANGOR DAILY IVHIG \& COURIER. Aug. 25, 1865, at 3; The Law in Regard to Homicide-The Charge of Chief Justice Appleton in the Case of James $H$. Williams, Indicted for Murder of James MCGras. BANGOR DAILY WHIG \& COURIER. Aug. 28,1865 , at 2.

537. Released on His Oun Testimony, BOSTON DAlly EVENING TRANSCR!PT. Aug. 31. 1865, at 2 The Transcript lifted much of the first line of this quote from the coverage of the Boston Dully Advertser See Letter from Bangor, BOSTON DAILY ADVERTISER. Aug. 28. 1865. at 1. The Adveritser. unlike the Transcript, noted in its coverage that in earlier murder casses tned after the passage of Mane's $186+$ law. the defendants' "lame and contradictory tesumony" had made convicuon "all the more certain." Id. Indeed. that was the judgment of the Maine Attorney General in his annual repon of 1864 . Sec REPORT OF THE ATTORNEY GENERAL OF THE STATE OF MAINE 6 (Augusta, Stevens \& Siyward 1861)

538. See Mark A. Barwise, Scientific Proof and Legal Proof. 8 ME. L. REv. 67. 76 (1914). I thank Herbert Silsby as well as Jeem Trowbridge of the Bangor Histoncal Society for leading me to the Banwise article.

539. Id. at 77 . 
false $e^{540}$ that it would be reckless to adopt it in any particular. Yet there is excellent evidence that both Paine and John Appleton were in Boston on May 9,1866 , the day the defendant testimony law cleared one of several legislative hurdles. ${ }^{541}$ In fact, evidence suggests that Paine was in the State House at the very time the House of Representatives, where Adams sat, voted on the bill. $^{542}$ There is some appeal to this possible link between Paine, the Williams trial, and the ultimate passage of a defendant testimony law in Massachusetts: For Williams was black, a fact reported in the Boston press, ${ }^{543}$ and his race added a new dimension to the North's vulnerability to Southern charges of hypocrisy.

540. Although the Boston papers did cover the Williams case, see supra note 537 and accompanying text, there was nothing remotely like a "furor," and any reference at all to the matter in the most prominent New York papers has proved elusive. John Quincy Adams II was not "then" sitting in the Massachusetts legislature. He was elected in November 1865-the Williams trial had been in August-and took his seat in January 1866. It is hard to imagine how Paine could have written the law in the same session in which it passed, as the law had to go from one chamber to the other and back again over the course of 11 days. See supra note 534. Moreover, there was nothing "unprecedented" about the haste with which the 1866 act was passed. Not only was the whole matter considered for months before its ultimate defeat in 1865, but the 1866 legislature required four months to turn Adams's initial proposal into law. See supra note 534. Perhaps, though, Paine meant only that the Massachusetts House acted on the legislation with unprecedented speed on the day he was there.

541. In a journal entry of May 13,1866, Bangor lawyer John Godfrey wrote that he had steamed to Boston the previous Monday (May 7), that his companions on the boat included Paine, and that they met up with Appleton in Boston. Godfrey and Paine returned home on Thursday, May 10. See THE JOURNALS OF JOHN EDWARDS GODFREY: BANGOR, MAINE 1863-1869, at 214-17 (James B. Vickery ed., 1979) [hereinafter GODFREY]. On Wednesday, May 9, the Massachusetts House amended the defendant testimony bill and ordered it to a third reading. See 1866 MASS. HouSE J. 389.

Still there are discrepancies between Godfrey's account and Paine's. First, Godfrey went to Boston to lobby before the legislature for a railroad bill. Although he does not say so explicitly, he leaves the strong impression that Paine was there on the same business-and not, at the invitation of Adams, to speak about the Williams case or assist with the defendant testimony law. See GoDFREY, supra, at 214-17. Moreover, although the Massachusetts House amended the defendant testimony bill on May 9, while Paine was in town, the best inference I can draw from legislative papers is that the amendment consisted merely of the deletion of one clause from section 1 and the deletion of section 2. Compare Mass. H.R. 361, at 13 (printing the bill on April 30, 1866), with An Act in Relation to Evidence in Criminal Prosccutions (transcribing the bill as passed by the House on May 12,1866) (unpublished document, on file with the Massachusetts Archives and with author). Not only was there nothing for Paine to write while sitting in Adams's chair, but this amendment made the bill, which until then had exactly tracked Maine's 1864 defendant testimony law, a little less like the Maine law. In any event, none of the handwritten documents contained in the legislative jacket for this act seems to bear Paine's handwriting. See Letter from Albert W. Paine to Oliver Otis Howard (Nov. 8, 1873) (Bowdoin College Library, O.O. Howard MSS No. 12331) (providing an example of Paine's handwriting).

I thank David Gold for pointing me to Godfrey's journal entry.

542. According to Godfrey's journal, he and others from Maine were in the Massachusetis Scnate at the time the railroad legislation that concerned them passed that house by a vote of 23 to 10 . See GODFREY, supra note 541, at 217 . Although Godfrey does not say, the context suggests Paine was among the group. The joumal of the Massachusetts Senate reports that the Senate approved a railroad bill on May 9 by a vote of 23 to 10 and that the vote had been scheduled to take place at 3:30 p.m. See 1866 MASS. SENATE J. 665 , 669. The journal of the House reports that the defendant testimony bill was amended and passed to a third reading on the afternoon of May 9. See 1866 MASS. HOUSE J. 389.

543. See The Fourth in Bangor-An Indian Regatta and a Murder, BOSTON HERALD, July 5, 1865. at 1; Letter from Bangor, Me., BOSTON DAILY ADVERTISER, Aug. 24, 1865, at 1; Lefter from Bangor, Me., BOSTON HERALD, July 8, 1865, at 4. 
Legal reformers in Massachusetts had long lamented that the operations of the criminal justice system affected African Americans disproportionately. ${ }^{\text {sti }}$ The end of the Civil War could only exacerbate matters. In 1865 the warden of the state prison worried publicly about a northward immigration of poor, unskilled freed slaves who would overburden the state's penal institutions. ${ }^{\text {sis }}$ Of the 15,000 criminal defendants whom Sawyer complained the old exclusionary law would silence, a fair number would have been African American. Those political leaders who fretted about the North's ideological purity in the eyes of the South must have feared that one such defendant might, like Williams, take center stage at a celebrated trial.

The prospect of a black man sitting silently at his own trial, accused (as Williams was) by white men, perhaps caught in the throat of those Massachusetts politicians who cried righteously of black witnesses silenced in the courts of the South. It is at the very least interesting that Paine's aging memory should have emphasized the role of the Williams case, in which the new Maine law operated to free a black man accused of murder. He apparently did not mention two earlier murder cases in Maine, in which two white men accused of murder took advantage of the state's new law, testified on their own behalf, and, by all accounts, assured their own convictions. ${ }^{3+6}$ In a political landscape not colored by the struggle between North and South, these latter cases would have made better ad copy.

\section{b. Other States}

Massachusetts was only one of many Northern, Midwestern, and Western states that acted in 1866 and succeeding years to permit criminal defendants to testify. I have chosen to focus on Massachusetts in part because it was one of the earliest states to follow Maine's 1864 lead, but also because the close historical connection between Maine and Massachusetts helps us to test whether the passage of defendant testimony laws in the 1860s and 1870s was simply another instance of the nation going as Maine goes. That is, if even in

544. In 1826, the Boston Prison Discipline Society called altention to the high proportion of blacks in the Massachusetts State Prison. See Hindus, supra note 402. at 236. In 1850. Afncan Amencans accounted for $0.9 \%$ of the Massachusetts population but $8.6 \%$ of the prison population See $u$ at $175-78$ Hindus reports that the overrepresentation of blacks in the prisons of Massachusetts was "constant." Id. at 237.

In 1849, in the midst of a reform movement to abolish the death penalty in Massachusetts. a black man named Washington Goode was convicted of murder. His race heightened the reformers' concern The Prisoners' Friend implored, "Let it not be said that the last man Massachuselts suffered to be hung was a colored man!" I JOHN M. SPEAR \& WeNDELL PHILLIPS. PRISONER'S FRIEND 400, 401 (Boston. Charles W. Spear 1849).

545. See Hindus, supra note 402, at 237 (citing Report ON THE STATE PRISON 22 (Boston. 1865)). The sensationalist Boston Herald often featured black defendants in its accounts of the goings-on in the local courthouses. See, e.g., Superior Criminal Court-Pumam. J., Boston Herald. May 12. 1865. al 2 I cannot say whether such stories gained greater prominence as the Cival War drew to a close

546. See supra note 537. 
Massachusetts the story was more complicated than that-and I hope I have shown that it was-then we must look for a more complicated story elsewhere as well.

In most states, unfortunately, the surviving record proves to be too thin to bear analysis. In others, such as California, the record has more depth but neither supports nor refutes the argument I have laid out above. ${ }^{547}$ And in Connecticut, perhaps the only Northern state in which legislative debate about a defendant testimony law survives, the evidence, though mixed, is largely unhelpful to my thesis. Two Hartford newspapers printed summaries of the House debate on the bill, ${ }^{548}$ which became law in July $1867 .^{549}$ Elements of the debate support my view that ancient notions of the power of the oath survived surprisingly late. One legislator, a trial judge, confessed that he had recently presided at the trial of a man who, in the judge's mind, "was innocent: yet $[\mathrm{I}]$ was obliged to convict" because "the testimony was positive against

547. In 1851, California barred testimony by nonwhites in its courts. See Act of Apr. 29, 1851, ch. V, $\S 394,1851$ Cal. Stat. 113, 114. In 1863, after Republican and Unionist victories in the clections of 1861 and 1862, the legislature made African Americans competent to testify and, six weeks later, made civil parties competent as well. See An Act To Amend an Act Entitled an Act To Regulate Proceedings in Civil Cases in Courts of Justice of this State, ch. CCCCXXVIII, 1863 Cal. Stat. 701 (adopted Apr. 27, 1863); An Act To Amend an Act Entitled an Act To Regulate Proceedings in Civil Cases in the Courts of Justice in this State, ch. LXVIII, 1863 Cal. Stat. 60 (adopted Mar. 16, 1863); Robert J. Chandler, Friends in Time of Need: Republicans and Black Civil Rights in California During the Civil War Era, 24 ARIz. \& W. 319, 324-29 (1982) (discussing the effect of the 1861 and 1862 elections on the racial exclusionary rule); Paul Finkelman, Prelude to the Fourteenth Amendment: Black Legal Rights in the Antebellum North, 17 RUTGERS L.J. $415,422 \mathrm{n} .33$ (1986) (attributing the 1863 law change to the Republican Party's rise to power in California); Arnold Roth, The California State Supreme Court, 1860-1879: A Legal History 101 (1973) (unpublished Ph.D. dissertation, University of Southern California) (on file with author).

In April 1866, California became the second state in the Union to enact a defendant testimony law. See Act of Apr. 2, 1866, ch. 644, \$ 1, 1865-1866 Calif. Stat. 865, 865. (In May, Massachusetts became the third.) At the beginning of the 1866 legislative session, the state's Republican attorney general announced that a defendant testimony law should be one of the state's legislative priorities for the year and made a suggestive but inconclusive reference to the issue of black testimony:

Author of the law admitting parties to the record and in interest to testify, and in favor of negro testimony, I do not see why some other disabilities should exclude. I am urging the modification now as purely a legal question, and in this light surely some of the grounds of exclusion are indefensible. ...

These disabilities should go to the credibility, not to the competency: to the weight, not to the entire exclusion; should be addressed to the jury, not the judge.

REPORT OF THE ATTORNEY-GENERAL FOR THE YEARS 1866 AND 1867, at 7 (n.p., D.W. Gelwicks n.d.). Unfortunately, whatever debate there may have been in the California legislature on the question of defendant testimony went unreported. In contrast, the local press gave extensive, seemingly verbatim coverage to the lively 1863 debates on the issue of testimony by nonwhites. See, e.g., SACRAMENTO UNION. Mar. 5, 1863 (reporting legislative debate); SACRAMENTo UnION, Mar. 6, 1863 (same); SACRAMENTo UNION, Mar. 7, 1863 (same).

Supporters of the "as goes Maine, so goes the nation" theory would find some support in two aspects of the California record: The California defendant testimony law followed the text of the Maine law word for word. Moreover, California's governor, who supported the new law, hailed from Maine. He stated his support for the defendant testimony law in terms Appleton would have approved: "Open the door wide for the admission of evidence, and let the jury be allowed unrestricted latitude in judging of its quality." 18671868 CAL. SEN. J. 34 (emphasis in original).

548. See Accused Parties Testifying for Themselves, HARTFORd Dally TIMES, June 28, 1867, at 2; Allowing Criminals To Testify, HARTFORD DAILY COURANT, June 29, 1867, at 6.

549. See Act of July 19, 1867, ch. 96, 1867 Conn. Pub. Acts 106. 
him." 550 Another legislator complained that under the existing law, "any scoundrel can trump up a charge against any innocent man, and swear a crime upon him." ${ }^{.551}$ Moreover, two legislators opposed the law on the grounds that it would "open a door to perjury" 552 -betraying an unmodern fear that the jury could not discern a lie when it saw one. But at least one legislator defended the law in terms Appleton or Bentham might have used, arguing that "[c]redibility is the only proper test, and this will be decided by the jury in the case of a prisoner as readily and as justly as in the case of a witness." And no legislator made any reference to the problem of racial exclusion laws in the South.

But in South Carolina, the defector from the general Southern resistance to permitting defendant testimony, commentators and lawmakers left an unusually clear and concise historical trail - and here the trail leads directly back to the controversy over racial exclusion laws. Toward the end of 1865 , South Carolina enacted a Black Code that shared with Mississippi's the distinction of being the most severe in the South. ${ }^{5 s t}$ On the question of black testimony, South Carolina made the barest concession that would satisfy the President in an effort to persuade him to return jurisdiction from the Freedmen's Courts to civil authorities: "In every case, civil and criminal, in which a person of color is a party, or which affects the person or property of a person of color, persons of color shall be competent witnesses." $35 s$ The next sentence constituted South Carolina's first substantial departure from the old common law system of exclusionary laws: "The accused, in such a criminal case, and the parties, in every such civil case, may be witnesses, and so may every other person who is a competent witness ...." "s6 My emphasis of the word "such" makes the already transparent legislative motive a little more so: The South Carolina legislature did not want it ever to happen that a black person could testify against a white person who could not testify in his own defense.

From here, the historical record grows only clearer. The inequities and humiliations imposed by the Black Codes of South Carolina and other Southern states drew swift condemnation from the North. The Northern press began to agitate for stronger constraints on Southern self-government than the conciliatory terms of Presidential Reconstruction had thus far imposed. Hoping

550. Accused Parties Testifying for Themselves, supra note 548 (remarks of Mr Storer)

551. Allowing Criminals To Testify, supra note 548 (remarhs of Mir Ives).

552. Id. (remarks of Mr. Woodward); see also Accused Parties Testufving for Themselves, supra note 548 (remarks of Mr. Graves) (using similar words).

553. Allowing Criminals To Testify. supra note 548 (remarks of Mr. Sumner)

554. See FONER, supra note 468. at 199. 200. 202.

555. An Act To Establish District Courts, \$ 30, 1865 S.C. Stat. 25. 25 Only three members of the South Carolina convention that enacted this law favored giving freedmen the nght to testify in cases in which blacks were not directly involved. See FRANCIS BUTLER SISIKINS \& ROBERT HILLIARD WOODY, SOUTH CAROLINA DURING RECONSTRUCTION 42 (1966).

556. $\S 30,1865$ S.C. Stat. at 25 (emphasis added). 
to stave off more Radical Congressional Reconstruction, South Carolina proved to be quite aggressive in accommodating Northern demands. ${ }^{557}$ In the late summer of 1866 the Governor called a special session of the legislature, which set to work on a new law code that would reverse the abuses of the previous year and permit state courts to regain jurisdiction from the federal Freedmen's Courts. ${ }^{558}$

As the legislature prepared to eliminate all distinctions of color from the rules governing witness testimony, a correspondent for the Charleston Courier worried that the elimination of the racial exclusion laws, combined with the survival of the other old competency rules, might create an unseemly imbalance. On August $20,5^{59}$ and again on September $5,^{560} 1866$, this correspondent described how two freedmen, charged with crimes, had attempted to claim that a white person had put them up to the act. After the second of these accounts, the correspondent continued:

This is by no means the only instance in which a freedman guilty of crime has endeavored to implicate a respectable citizen as an accomplice.... Our citizens have reason to be sensitive on this subject ... . Perhaps our Legislature, in view of the great changes which have come upon the land and the necessity of providing for the protection of the people, will at last realize the importance of giving the parties to a cause, either in a civil or criminal action, the right to testify. The Court or Jury can decide on the degree of credit to be attached to such evidence. In support of this suggestion some of the first lawyers in the State could be named, and it certainly is a measure in which the safety and interests of the individual citizen are deeply involved. It is a current opinion that with fifty dollars enough testimony of a certain kind can be manufactured and brought up to convict almost any one of the gravest crimes; and it is therefore considered important that an accused person shall be allowed to give his own testimony on oath, which in a nicely poised case might be

557. "Realizing the futility of the policy they had been pursuing, the South Carolina leaders modified their conduct in hopes of averting the doom which Congress seemed to have in store for them. They revised the "black code' ...." SIMKINS \& WOODY, supra note 555, at 58. At the August 1866 national union convention, Governor James L. Ort of South Carolina is said to have marched arm in arm with General Darius Nash Couch of Massachusetts. See Frederick W. Dallinger, Massachusetts in Reconstruction (1865-1871), in 4 COMMONWEALTH HISTORY OF MASSACHUSETTS 556 (Albert Bushnell Hart ed., 1930).

558. Govemor Orr opened the session with these words: "I have convened the General Assembly in extraordinary session, for the purpose of recommending such modifications of existing laws with reference to persons of color as will entitle the tribunals of this State to exercise jurisdiction over them in all

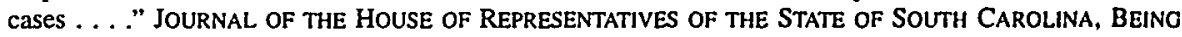
THE EXTRA SESSION OF 1866, at 9 (Columbia, Julian A. Selby 1866). He added later that "[w]hen our laws are so modified that all persons may be tried before the same tribunal, and, upon conviction, subjected to the same punishment for the same class of offences, all reason for the interference of Federal authority with the administration of justice will have ceased." $I d$.

559. See Our Sumter Correspondence, Charleston Daily Courier, Aug. 20, 1866, at 4.

560. See Our Sumter Correspondence, ChARLESTON DAlLY COURIER, Sept. 5, 1866, at 4. 
sufficient to turn the scales in his favor. It is in the power of the Legislature to give this additional safeguard to the citizen. ${ }^{\text {\$61 }}$

One can see between the lines the writer's concern that white citizens were now at the mercy of freedmen who, for "fifty dollars," would "manufacture[l" "enough testimony of a certain kind ... to convict almost any one of the gravest crimes."

The legislature proved sympathetic to the correspondent's concern. Bowing to Northern pressure to eliminate color-based distinctions in its laws, it decreed "[t]hat all persons hitherto known in law in this State as slaves, or as free persons [of] color, shall have the [same] right to ... give evidence ... as white persons now have." 562 But the legislature also bowed to the concerns of its white citizenry and eliminated entirely the common law bar against the testimony of interested persons, civil parties, and criminal defendants. ${ }^{563}$

South Carolina's was not the only Southern state legislature to address the fear that freedmen, now made competent to testify under Northern pressure, might testify against whites who were barred from testifying under the old competency rules. In neighboring North Carolina, at the same moment the legislature grudgingly made nonwhites competent "in all controversies . . where the rights of persons or property of persons of color, shall be put in issue," it also provided that "no person shall be deemed incompetent to bear testimony in such cases, because of being a party to the record." 564 Two days later, North Carolina simply made all civil parties competent. ${ }^{\text {sos }}$ In Alabama, in the same act by which the legislature made African Americans competent in a limited group of cases, it provided that "in all cases . . in which a freedman . . . is a witness against a white person, or a white person against a

561. Id. I owe this striking quotation to Alexus Haller's sharp cye

562. An Act To Declare the Rights of Persons Lately Known as Slases and as Free Persons of Color. No. 4798, 1866 S.C. Acts Extra Sess. 393. 393-94. In proposing this expansion of the nghts of freedmen to testify at the outset of the special legislative session. Governor On told the legislaton

[The former provision]. admitting persons of color to testufy in all cases where themselves or their race are directly concemed. and excluding them by implication in all cases where they are not interested, cannot be reconciled with sound policy or just discrimination They are admitted in that class of cases where their interest, sympathy, association and feelings would be most likely to pervert their consciences and invite to false sueanng. and are excluded from testifying in all cases where no motive could exist to swear falsely, except that of a depraved heart. The distinction is illogical and indefenstble, and 11 cannot be dented that it has th foundation in a prejudice against the caste of the negro.

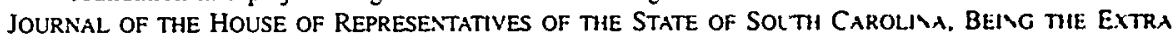
SESSION OF 1866. supra note 558, at 10.

563. See No. 4798, 1866 S.C. Acts Extra Sess. at 393-9.4. The Governor signed the act intu law on

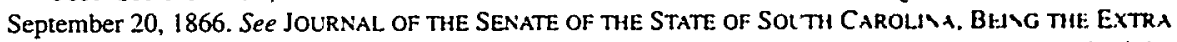
SESSION OF 1866, at 57 (Columbia, Julian A. Selby 1866) The Courier announced its approval of the downfall of the competency rules. See The Late Change th the Rules of Eindence. CuARL.tSTOV Dally COURIER, Oct. 5,1866 , at 2.

564. An Act Concerning Negroes and Persons of Color or of Mixed Blood. ch 40. $\$ 9.1866 . \mathrm{C}$ Pub. Laws 99, 102 (emphasis added).

565. See An Act To Improve the Law of Evidence, ch 43. \$2. 1866 . C Laus 112. 112 
freedman ... the parties shall be competent witnesses." ${ }^{566}$ It is very likely that this same impulse is what moved several other states-California, Florida, Kansas, Kentucky, Louisiana, Oregon, and Virginia-to make civil parties competent at virtually the same time they made nonwhites competent. South Carolina may have been unusual, therefore, only in this narrow sense: In seeking to avoid the spectacle of freedmen testifying against whites who, as parties, were incompetent to testify, most states were content to abolish only the civil parties ban. In also permitting testimony by criminal defendants, South Carolina protected even accused criminals from this perceived ignominy.

\section{E. The Link to African Americans' Right To Testify: Assessing the Evidence}

The political dynamic at work in South Carolina was very unlike that in Massachusetts. In South Carolina, external forces demanded that the state permit blacks to testify. Insecure white citizens then demanded that all competency rules be dropped so that white parties would not find themselves silenced in the face of a black person's accusation. In Massachusetts, a campaign to force the South to abolish its racial exclusion laws required the North to abolish its own competency rules-otherwise the South could have complained of Northern hypocrisy. These two political dynamics have a certain appealing symmetry, but as historical explanations, they are in no sense synergistic. That is, the rather clear evidence that South Carolina permitted criminal defendants to testify because it had been forced to permit blacks to testify does not make my theory of what happened in the North appreciably stronger.

A good deal remains to be explained about the pattern of adoption of defendant testimony laws. The clear North-South bias outlasted any live controversy about the legality of racial exclusions. The Civil Rights Act of $1866^{567}$ decreed that all persons shall have the same right to give evidence as white persons. Although some Southern and border states denied that Congress had power under the Thirteenth Amendment to dictate the rules of evidence in state courts, ${ }^{568}$ the ratification of the Fourteenth Amendment in 1868 surely settled all such doubts. Meanwhile, Radical Reconstruction was altogether reshaping the political landscape of the South. Yet, of the nineteen state and territorial legislatures that acted during the 1870s to grant criminal defendants the right to testify, none belonged to the old Confederacy, and only

566. An Act To Protect Freedmen in Their Rights of Person and Property in This State, No. 86, 1866 Ala. Acts 98 (adopted Dec. 9, 1865).

567. An Act To Protect All Persons in the United States in Their Civil Rights, and Furnish the Means of Their Vindication, ch. 31, 14 Stat. 27, 27 (1866).

568. See, e.g., Bowlin v. Commonwealth, $65 \mathrm{Ky}$. (2 Bush) 5, 7, 10 (1867). For the legal and historical context of this case, see Robert D. Goldstein, Blyew: Variations on a Jurisdictional Theme, 41 STAN. L. REv. 469, 483-513 (1989). 
two were border states. Not until the 1880 s did the Old South begin to fall in line.

I cannot explain the long survival of this North-South distinction, though I can offer guesses about its cause. If, as I have argued, Northern states first passed defendant testimony laws as part of their campaign to force Southern states to abandon their racial exclusion laws, then it perhaps should not surprise us that Reconstruction legislatures in the South did not rush to permit defendants to testify. Not only were the racial exclusion laws in question largely gone, but even at the height of Radical Reconstruction the fear of perceived hypocrisy that once had motivated the North would have been altogether alien to a Southern lawmaker. As for later years, it surely seems possible that Southern states continued to shun defendant testimony laws because they still associated such laws with Northern Radicalism. The comment of one North Carolina legislator in 1881, who opposed a defendant testimony law as a "Yankee innovation," gives some force to this speculation (though the legislator seems to have directed the remark at a clause of the bill that permitted defendants' spouses to testify). ${ }^{569}$ A satisfying explanation of the persistence of the North-South bias past the 1860s, however, must await more study. For now, I hope I have succeeded in the more modest task of identifying the trigger that first set off the distinctly Northern explosion of defendant testimony laws in the 1860s. In that decade, the long and slowly rising historical trajectory of the jury's development as our system's lie detector passed close to the gravitational field of a far greater historical force and was, if only briefly, yanked toward the future.

\section{THE AlLuRE OF THE BLACK BOX}

The defendant testimony laws of the late nineteenth century removed the last great barrier shielding juries from full frontal credibility conflicts of the sort they face so routinely today. In 1882, not even twenty years after Maine first let accused criminals take the oath in their own defense, one observer declared that the direst predictions of the opponents of the new laws had come true:

Experience has, beyond all question, proved [the defendant's option to testify] to be the most powerful and the most fruitful incentive to perjury ever devised by the legislator. In total disregard of that ever-present and irresistible instinct of self-preservation, which is "nature's first law," it holds out to the man guilty of crime the overpowering temptation of denying his guilt under oath, in the

569. A Field Day in the House, Dally ChaRlotte ObServer. Feb. 20. 1881. at I (remarks of Mr. Manning). 
delusive hope that he will be believed, thus adding perjury to his other crime. ${ }^{570}$

The jury now faced the most demanding lie-detecting task it had yet encountered: In criminal cases, where the standard of proof was beyond a reasonable doubt and the stakes were the life or liberty of the defendant, the jury would have to listen to the prosecution's sworn accusation and the defendant's sworn denial and label one of them truth and the other lie.

Yet the system did not, as I hope I have made clear, invest the jury with this new lie-detecting role because of a conviction that the jury had grown equal to the task. It is true that over the preceding centuries the system had slowly complicated the jury's lie-detecting work in criminal cases, first by permitting the defendant to call witnesses, then by permitting those witnesses to be sworn. It is true that Bethel's rule and the other common law evidence rules that sought to guide juries when they confronted apparent conflicts of oaths had slowly eroded. And it is true that in the decades before Maine and other Northern states tore down this last great barrier to conflicts between oaths, many jurisdictions had begun to dismantle the system of competency rules that sought to keep the most likely liars from reaching the witness stand. There is no doubt that the bar against sworn defendant testimony would have fallen in due time-this was surely one of those battles between past and future that the future was destined to win. ${ }^{571}$ Still, the epochal conflict between North and South brought change before its time. The system perhaps had to struggle to summon the confidence in its juries that its laws now proclaimed.

We catch glimpses of this struggle in the early resistance by some of the system's players to the full consequences of change. California trial judges advised juries to take particular care in evaluating the defendant's testimony in light of "the consequences to him relating from the results of this trial and the inducements and stipulations which would ordinarily influence a person in

570. Departures from the Common Law Rule as to Testimony by Husband and Wife, 3 CRIM. L. MAG. 155,162 (1882). The previous year, during debate about whether to adopt a defendant testimony law, a North Carolina legislator said it "ought to be entitled a bill to allow defendants to commit perjury." $A$ Field Day in the House, supra note 569 (remarks of Mr. Rowland). Another argued that North Carolina's 1866 law permitting civil parties to testify "had worked a full crop of perjury." Id. (remarks of Mr. Glenn). On the other hand, two legislators expressed full confidence that the jury could detect any such perjury. "[L]iars cannot fool juries," said one. Id. (remarks of Mr. Day). The other declared that "[a] jury of twelve men are quick and sharp to tell whether a man is telling the truth." Id. (remarks of Mr. Grainger).

571. Cf. GRANT GilmoRe, THE DEATH OF CONTRACT 65 (1974) ("The future, of course, won, as it always does."). Some contemporaries perceived the issue in these terms. In 1881, a North Carolina newspaper paraphrased the words of a legislator advocating a proposed defendant testimony law: "[He said] the method proposed was up to the spirit of the age and in accordance with its progress. He did not desire to see North Carolina left behind. He knew that some day it would be adopted, and the present was as good a time as any." The General Assembly of North Carolina, RALEIGH NEWS \& OBSERVER, Feb. 2, 1881, at 2 (remarks of Mr. Davidson). 
his situation. ${ }^{1572}$ Rejecting a defendant's challenge to this instruction in 1882 , the state's supreme court noted curtly that "[i]t is only by virtue of a provision of the Code that [the defendant] is permitted to testify at all, and it is manifest that he labors under the strongest temptation to which any witness could be subjected." 573 But while courts in some cases worried that juries would weigh the defendant's oath too heavily, cours in other cases took care that juries not dismiss his oath too lightly. In 1886, the Nebraska Supreme Court considered the consequence of the state's 1873 statute giving criminal defendants the right to testify. ${ }^{574}$ Nebraska had not formerly required corroboration of a victim's testimony in rape cases, ${ }^{575}$ but the court now held that when a man charged with rape denied the victim's accusation under oath, a jury could not convict unless some additional evidence weighed with the victim's account. ${ }^{576}$ As the Missouri Supreme Court explained in adopting Nebraska's new rule, the defendant's sworn denial "creat[es] an equipoise of oath against oath" that bars conviction without corroboration. "Although the Missouri court retracted its reasoning in 1897 and affirmed "the jury's duty and prerogative ... to weigh all the evidence and credit that which to them appears most reasonable and creditable, ${ }^{" 578}$ Nebraska adhered to its rule, ${ }^{579}$ and turn-of-the-century courts in Illinois, ${ }^{580}$ Oklahoma, ${ }^{581}$ and New Mexico ${ }^{582}$ followed Nebraska's lead.

Such cases show the system's growing pains as it adjusted to the jury's expanding lie-detecting role. The system has long since overcome this adolescent awkwardness at the new credibility conflicts in its courts. But even today we can see artifacts of an earlier time-reminders that the system was

572. People v. Morrow, 60 Cal. 142, 147 (1882): see also Stale v. Maguire. 69 Mo 197. 201.02 (1878) (approving an instruction "that by the statutes of this State the defendant is a competent witness in his own behalf, but the fact that he is a witness tesufying in his own behalf, may be considered by the jury in determining the credibility of his testimony"): St. Louls v. Statc. 8 Neb. $405 .+18$ (1879) (endorsing an instruction that the jury was "at liberty to consider the great interest which [the defendant] has in the result").

573. Morrow, 60 Cal. at 147. I am grateful to Barbara Babcock for this reference

California's modern-day instruction advises junes that they may "consider anything that has a tendency in reason to prove or disprove the truthfulness of the testimony of the witness. ineluding . [t]he existence or nonexistence of a bias, interest, or other motive." CALIRORNIA JURY INSTRLCTIONS. CRIWINAL $\$ 2.20$ (West 1993). It does not highlight the criminal defendant's particular motive to lie. The Ninth Circuit's pattem instruction says simply, "You should consider the teslımony of the defendant just as you would the testimony of any other witness." NINTH CIRCUIT MODEL CRIMINAL JURY INSTRL CTIONS $\$ 307$ (1995).

574. See Matthews v. State, 27 N.W. 234, 237 (Neb. 1886). Tamı Swiger pointed me to this very interesting line of cases.

575. See, e.g., Garrison v. People, 6 Neb. 274. 283 (1877).

576. See Matthews, 27 N.W. at 237.

577. State v. Patrick, 107 Mo. 147, 173 (1891); see also id. at 1.49 (argument of defense counsel) (citing Mathews to the court).

578. State v. Marcks, 140 Mo. 656. 668 (1897).

579. See Klawitter v. State, 107 N.W. 121, 121 (Neb. 1906).

580. See Stevens v. People, 41 N.E. 856, 858 (III. 1895).

581. See Sowers v. Territory, 6 Okla. 436, 451 (1897).

582. See Mares v. Territory, 10 N.M. 770,778 (1901). 
once not so confident in the jury's role as full and final arbiter of the credibility of witnesses. Followers of the O.J. Simpson murder trial will recall that Judge Ito instructed the jurors on an only slightly modernized version of the rule of falsus in uno, falsus in omnibus. Without naming Detective Mark Fuhrman and without highlighting Fuhrman's proved lie about his past use of a racial slur, Ito advised the jury that "[a] witness who is willfully false in one material part of his or her testimony is to be distrusted in others." 583 Although California, like other states that have retained some version of this rule, merely provides that juries may disbelieve the entire testimony of a witness who has lied about one material fact, this more modern version of the rule spares a jury, if it chooses, the task of wrestling with the comparative credibility of competing witnesses.

Moreover, many modern jurisdictions continue to require something more than a lone witness to make out a prosecution for perjury. ${ }^{584}$ It is not that perjury is too serious a crime for conviction to ride on a single witness's word-after all, a single witness is enough to condemn a defendant for murder. Rather, this rule recalls the system's old reluctance to pit one oath against another. We see more startling relics of the old ways in scattered statements that sworn testimony is presumed truthful. ${ }^{585}$ The corollary rule that the jury may not disbelieve the unimpeached, uncontradicted testimony of a disinterested witness seems still to thrive in civil courts ${ }^{586}$ and, although

583. Pre-Instructions to the Jury, People v. Simpson, No. BA097211, 1995 WL 23581, at *36 (Cal. Super. Ct. 1995); see also CALIFORNIA JURY INSTRUCTIONS, CRIMINAL $\S 2.21 .2$ (West 1993) (providing quoted language). More typically, modern juries are told that they "may believe everything a witness says, or part of it, or none of it." NINTH CIRCUIT MODEL CRIMINAL JURY INSTRUCTIONS $\$ 3.07$ (1995).

584. See supra note 114 and accompanying text.

585. See, e.g., Adams v. State, 542 N.E.2d 1362, 1370 (Ind. Ct. App. 1989) ("You should attempt to fit the evidence to the presumption that the defendant is innocent and the theory that every witness is telling the truth." (quoting INDIANA PATTERN JURY INSTRUCTIONS, CRIMINAL, Preliminary Instruction No. 1.23, at 25)); State v. Hart, 625 P.2d 21, 31 (Mont. 1981) ("A witness is presumed to speak the truth; but this presumption may be repelled . . . .); State v. Kessler, 458 P.2d 432, 434 (Or. 1969) ("Now every witness is presumed to speak the truth. This presumption may be overcome . . . "). But see, e.g., Williams v. State. 520 So. 2d 179, 181 (Ala. Crim. App. 1987) ("In Alabama, there is no presumption that a witncss is telling the truth."); Laster v. State, 521 A.2d 1289, 1290-92 (Md. Ct. Spec. App. 1987) (holding it error to instruct a jury that witnesses should be presumed truthful, at least where the only witnesses are state witnesses); State v. Thompson, 504 N.W.2d 838, 840-43 (N.D. 1993) (holding it reversible error to instruct, "If you find a conflict in the evidence, you should reconcile it, if you can, because each witness is presumed to have told the truth').

The Supreme Court has acknowledged that there is "substantial unanimity among federal courts of appeals that [a presumption-of-truth instruction] ought not to be given." Cupp v. Naughten, 414 U.S. 141, 146 (1973); see id. at 143-44 \& n.4, 145; see also Walter W. Jones, Jr., Annotation, Propriety and Prejudicial Effect of Instruction, in Federal Criminal Trial, That Witnesses Are Presumed To Tell the Truth, 8 A.L.R. FED. 319 passim (1971).

586. Guy Wellbom points to various authorities for the modem rule. See Olin Guy Wellborn III, Demeanor, 76 CORNELL L. REv. 1075, 1100 \& n. 120 (1991) (citing FlEMING JAMES, JR. \& GEOFFREY C. HAZARD, JR., Civil Procedure $\$ 7.19$, at 364-65 (4th ed. 1992); 9A Charles Alan Wright \& ARTHUR R. Miller, FEderal PRACTICE AND PROCEDURE § 2527, at 286-88 (2d ed. 1995) (deeming "preferable" the "majority view" that "the jury is required to believe . . . uncontradicted and unimpeached evidence from disinterested witnesses"); Edward H. Cooper, Directions for Directed Verdicts: A Compass for Federal Courts, 55 MINN. L. REV. 903, 930-40 (1971) (same); W.E. Shipley, Annotation, Credibility of Wilness Given Uncontradicted Testimony as Matter for Court or Jury, 62 A.L.R.2d 1191 (1958) (noting that many 
generally rejected in criminal courts, ${ }^{587}$ makes occasional appearances there in a vaguer and more permissive form. ${ }^{588}$ Perhaps, as Fleming James and Geoffrey Hazard suggest, the rule "amounts to a holding that reasonable people could not disbelieve such testimony on the basis of demeanor evidence." 589 Even if the rule were nothing more than a vote of no confidence in the jury's powers to detect a lie based on a witness's demeanor, it would be hard to reconcile with our modern image of juries as the sole and unconstrained judges of credibility.

We find, too, relics of those rules that pronounced on the credibility of certain witnesses. In many modern jurisdictions, the testimony of an accomplice standing alone remains insufficient to support a criminal conviction. ${ }^{590}$ Until about a generation ago, a rape victim's uncorroborated word was in many places insufficient to convict (whether or not the defendant denied the charge under oath-the condition of Nebraska's unusual rule). ${ }^{591}$ Corroboration rules for accomplices and rape victims are vestiges of the institutional suspicion we saw directed at such witnesses in proceedings at the Old Bailey over two centuries ago. ${ }^{52}$ But these rules reflect suspicions about the jury as well-an institutional fear that the jury will fail to see how untrustworthy such witnesses are and will overcredit their testimony. ${ }^{593} \mathrm{By}$ deeming accomplices and rape victims less credible than other witnesses as a matter of law, such rules deny to juries the full power to assess credibility.

but not all American jurisdictions follow the rule in civil cases)).

587. See Shipley, supra note 586, at $1210-11$.

588. See, e.g., Sweany v. State, 607 N.E.2d 387. 389 (Ind. 1993) (approving a "pattem" jury instruction stating, "You should not disregard the testimony of any witness without a reason and without careful consideration").

589. JAMES \& HAZARD, supra note 586, § 7.19, at 364-65.

590. As of 1990, the date of the last thorough survey. 16 states and Puento Rico had accomplice corroboration statutes; two states had established the rule by case law. See Chnsune J. Saverda. Note. Accomplices in Federal Court: A Case for Increased Evidention Standards, 100 YALE LU. 785. $790-91$ nn.40-41 (1990); Edmund J. O'Meally. Recent Decision. Tumer v. State-Should an Accomplice's Excited Utterance Corroborate His In-Court Testimony?, 42 MD. L. REv. 571 . 573 nn.18.19 (1983).

591. See 7 WIGMORE, supra note $44, \$ \$ 2061-2062$, at $342-57$ (describing corroboration nules of various jurisdictions as of 1940). As of 1972, 15 American junsdictions mantaıned some form of corroboration requirement in rape cases. See Note, The Rape Corroboration Requirement: Repeal Nor Reform, 81 YALE L.J. 1365, $1367-68$ (1972) (citing statutes embracing a corroboration requirement).

592. See supra notes 319,327-328 and accompanying text: see also SUSAN ESTRICH. REAL RAPE 4347 (1987) (arguing that courts enfored the corroboration requirement when they mistrusted the complainant's testimony); 7 WIGMORE, supra note 44 , 2061 . at 345 (quoung Hale's notonous injunction that "it must be remembered that [rape] is an accusation easily to be made and hard to be proved: and harder to be defended by the party accused, tho never so innocent"): Note. Corroborating Charges of Rape. 67 COLUM. L. REV. 1137, 1138 (1967) ("Surely the simplest. and pertaps the most important, reason not to permit conviction for rape on the uncorroborated word of the prosecutrix is that that word is very often false.").

593. See Note, supra note 592, at 1139 (reasoning that a jury "cannot always be inusted to resolve la rape charge] fairly" because of "the respect and sympathy naturally felt by any tribunal for a wronged female"" (quoting 3 WIGMORE, supra note $44 . \S 924 a$, at 459)). 
Corroboration rules of course have begun to fade. Those applying to rape victims have largely passed from the scene, ${ }^{594}$ and those addressing accomplices are now rarer than they were. ${ }^{595}$ But the disappearance of these rules probably owes little to a conviction that juries have grown more able to assess the credibility of these supposedly troublesome witnesses. Corroboration rules in rape cases were abolished in the 1970s, together with other features of the old rape law that protected the defendant at the victim's expense. Like laws that defined away the possibility of marital rape and that exposed rape complainants to the most invasive interrogation about their sexual pasts, corroboration rules in rape were brought down by a social revolution and not by a legal reform. The gradual demise of accomplice corroboration rules probably owes much more to a sharpened political distaste for anything hindering the prosecution of crime than to new faith in the jury's capacity to

594. No American jurisdiction retains a general corroboration requirement in rape cases. Georgia abolished the last remaining statutory rule in 1978, see An Act To Amend Code Section 26-2001, Relating to Rape, So as To Delete the Provision That No Conviction Shall Be Had for Rape on the Unsupported Testimony of the Female; To Repeal Conflicting Laws; and for Other Purposes, No. 754, 1978 Ga. Acts 3, 3-4 (adopted Jan. 20, 1978), and Nebraska the last remaining common law rule in 1989, see An Act Relating to Criminal Procedure; To Eliminate the Requirement of Corroboration of Testimony for Certain Offenses; To Repeal Section 29-2013, Reissue Revised Statutes of Nebraska, 1943; and To Declare an Emergency, $1989 \mathrm{Neb}$. Laws 443. Several states still require corroboration in specific cases. See, e.g., CAL. PENAL CODE $\$ 262$ (West 1997) (requiring corroboration in cases of spousal rape if the victim made no complaint to an official or counselor within one year); GA. CODE ANN. \& 16-6-3 (1996) (requiring corroboration in statutory rape prosecutions); MISS. CODE ANN. § 97-3-69 (1996) (same); N.Y. PENAL LAW $\S 130.16$ (McKinney 1987) (requiring corroboration when alleged lack of consent is due to mental defect or incapacity); TEX. CRIM. P. CODE ANN. $\$ 38.07$ (West 1995) (requiring corroboration when the victim made no complaint within one year of the assault, unless the victim was less than 18 years old).

595. Between 1973 and 1990, seven of the 24 American jurisdictions that had retained accomplice corroboration statutes abandoned them. See Saverda, supra note 590, at 790-91 n.40. At least one state, however, newly adopted the rule by case law. See State v. Copeland, 677 S.W.2d 471, 474 (Tenn. Crim. App. 1984) (citing McKinney v. State, 552 S.W.2d 787 (Tenn. Crim. App. 1977)).

The history of the accomplice corroboration rule in the United States does not carve a straight line. In England, as noted earlier, a corroboration rule that was clearly in force during at least part of the 18th century was abandoned toward the end of the century and replaced by a cautionary instruction to the jury. See supra note 326 and accompanying text; see also FRANCIS WHARTON, A TREATISE ON THE LAW OF EVIDENCE IN CRIMINAL ISSUES 353 (Philadelphia, Kay \& Brother, 8th ed. 1880). By the mid-19th century, most American jurisdictions seem to have followed the later English practice: The jury had the power to convict on an accomplice's uncorroborated word, but trial judges had the obligation to warn the jury to use great caution or even, simply, to acquit. See, e.g., Commonwealth v. Larrabee, 99 Mass. 413, 415 (1868) ("[I]t is usual to instruct the jury ... that it is unsafe to convict upon such evidence . . .."); People v. Costello, I Den. 83, 87 (N.Y. Sup. Ct. 1845) ("The court certainly should advise great caution on the part of the jury ...."); State v. Wingo, 11 S.C. 275, 275 (1878) ("“[T]he presiding judge ought to advise the jury to acquit the prisoner." (quoting authority)). Francis Wharton put the point more strongly: Not only should the judge "advise the jury not to convict" on uncorroborated accomplice testimony, but the judge should set aside the verdict if the jury nonetheless convicts. See WHARTON, supra, at 352-53. This "general[]" rule, as Wharton calls it, id. at 352 , of course differs very little from a true corroboration requirement.

Those states that enacted formal corroboration rules seem to have done so between 1850 and 1900 . See Derek J.T. Adler, Note, Ex Post Facto Limitations on Changes in Evidentiary Law: Repeal of Accomplice Corroboration Requirements, 55 FORDHAM L. REV. 1191, 1202-03 nn.69-70 (1987). Wigmore explained these statutes as a reaction to laws passed earlier in the 19 th century forbidding trial judges to comment to juries on the evidence. See supra notes $447-448$ and accompanying text. In lieu of the old cautionary instruction, he says, many states put in place strict corroboration rules. See 7 WIGMORE, supra note $44, \S 2056$, at $315-21$. 
judge accomplice testimony. Once again, as we have seen throughout the long history I have sketched here, social and political forces worked changes in the law that required the system, after the fact, to stake more faith in the jury's liedetecting role.

It hardly seems likely, however, that a series of widely spaced and seemingly disconnected social forces-the Glorious Revolution of 1688, the American Civil War of the 1860s, the feminist revolution of the 1970s-could account fully for the jury's growing role as the system's lie detector. Such a historical account, implausible on its face, would grow ungainly and ridiculous if it tried to account for all the other moments and trends that in great ways and small have increased the factinding autonomy of the jury. Some of these I have mentioned already: The newly found right of criminal defendants in the middle of the sixteenth century to call unsworn witnesses, which I can attribute to no particular historical event except perhaps the anecdotal and unexplained largesse of Queen Mary; the slow deaths of Bethel's rule, the principle of numerology, and the rule of falsus in uno; and the demise of competency rules in civil cases in the mid-nineteenth century, which Jeremy Bentham or Andrew Jackson may or may not have inspired. ${ }^{596}$

It would be foolish to argue that each of these trends and events traces to a political or social controversy that operated outside the justice system. I make no such claim here. On the contrary, when all of these historical transformations are lined up alongside one another, they permit one broad and inescapable historical generalization: At least over the last several centuries and arguably since its founding, the criminal trial jury has consistently increased its lie-detecting role, while the role of the oath in assuring the accuracy of evidence at trial has steadily diminished. Perhaps, as I have argued here, specific events external to the justice system triggered the most notable transformations along this road. Something internal to the system, however, must have made those transformations so welcome and enduring-otherwise, we would expect to see some reversals along the road. Yet, the jury's role as the system's lie detector has only grown and has never, for a sustained time, diminished. ${ }^{597}$

596. There are many other such moments and trends that I have not considered here. both for want of space and because they do not bear directly on the jury's lie-detectung role-ihough they do bear on its general factfinding powers. The most imporant of these was the 1670 ruling in Bushel's Case. 124 Eng. Rep. 1006 (C.P. 1670), which barred trial judges from fining and impnsoning jurors who insisted on retuming a verdict with which the judge disagreed. Perhaps the best. most comprehensive treatment of Bushel's Case is in GREEN, supra note 19. al 236-49.

Bushel's Case is the most notable event within a broader trend away from direct judicial meddling in jury factfinding. Judges may no longer quiz the jury on the nature of its deliberations. call on the jury to reconsider a verdict unsatisfactory to the count. or require the jury (at least in criminal cases) to answer special interrogatories rather than retum a general verdict See WAYNE R. LAFAVE \& JEROLD H. ISRAEL. CRIMINAL PROCEDURE $\$ 24.7 \mathrm{a}$, at 1050 (2d ed. 1992) (noting that spectal verdicts in cnminal cases are "not favored").

597. In the 19th century, many states increased the factfinding and lic-detcelung powers of junes by barring trial judges from commenting on the strength of the evidence or the credibility of witnesses By 
I suggest that the most substantial force behind this enormous historical trend has been the system's concern with its own apparent legitimacy. In Part I, I argued that this concern drove the system to embrace the oath as a channel to divine wisdom after the abolition of the ordeal had removed the divine sanction from criminal verdicts. Yet, the oath, for reasons that are perhaps already too clear, was an inherently unstable source of systemic legitimacy. Its illusory power to assure truthful outcomes depended on a contorted scheme of feints and screens. Because obvious perjury would have exposed the oath's incapacity to guarantee truthful testimony, the system did not undertake to punish perjury. Because contradictory oaths would have exposed the oath as a failure, the system forbade contradictory oaths. When the system finally relented and began to permit defense witnesses to contradict the oaths of prosecution witnesses, it forbade them to do so under oath. When it later permitted defense witnesses to be sworn, it did what it could to prevent head-to-head credibility conflicts that would have exposed one witness as a liar. A bevy of competency rules sought to keep the likeliest liars from the witness stand, and Bethel's rule helped juries to evade the conclusion that oaths were in conflict.

As we now know, these contorted maneuverings to protect the system's legitimacy actually eroded that legitimacy. Bentham aimed his most withering ridicule at the old system of competency rules, which he said purported to guard the truth but in fact merely hid from the jury many potential sources of truth. ${ }^{598}$ But long before Bentham and long before the Enlightenment or the Scientific Revolution, ordinary people must have shaken their heads in

1913, 41 states had followed this trend in reversing the old common law practice that permitted such comment. See Krasity, supra note 447 , at 595; supra notes $447-448$ and accompanying text. In the 1940 edition to his treatise, Wigmore expressed great hope that states had begun to repent "[t]his unfortunate departure from the orthodox common law rule," 9 WIGMORE, supra note 44, $\$ 2551$, at 504-05, and were restoring judges' right to comment, see id. $\$ 2551 \mathrm{a}$, at $512-13$. In a footnote, Wigmore then listed three states that recently had acted to permit judicial comment (California, Michigan, and New Mexico), two states that had considered but rejected such action (Colorado and Massachusetts), and one state in which a commission had proposed the change in 1937, with no update on its progress (New York). See id. § 2551 a, at 513 n.4.

In the 1981 edition of Wigmore's treatise, in an otherwise virtually unchanged paragraph, both the proclamation of progress among the states and the footnote are gone. See 9 JOHN HENRY WIGMORE, EVIDENCE IN TRIALS AT COMMON LAW § $255 \mathrm{Ia}$, at 674 (James H. Chadbourn ed., 4th rev. ed. 1981). The editor comments sadly that "[d]espite the progressive movement [of the 1930s], the latest development is retrogressive"-that is, toward more lie-detecting power for the jury. Id. at 678.

In California, which restored judicial comment in 1934 by constitutional amendment, see 9 WIGMORE, supra note 44, $\$ 255 \mathrm{la}$, at 513 n.4, judges retain that power today. See CAL. PENAL CODE $\$ 1093$ (West 1997) ("The judge may . . make such comment on the evidence and the testimony and credibility of any witness as in his opinion is necessary . . . .). They may not, however, "'usurp the jury's exclusive function as the arbiter of questions of fact and the credibility of witnesses."' People v. Melton, 750 P.2d 741, 752 (Cal. 1988) (quoting People v. Cook, 658 P.2d 86, 91 (1983)). In at least a few other states, judges may still comment on the weight of the evidence. See, e.g., State v. Marra, 610 A.2d 1113, 1130 (Conn. 1992); Commonwealth v. Rough, 418 A.2d 605, 610 (Pa. Super. 1980).

598. See supra notes $394-398$ and accompanying text. 
wonderment at a system designed to find truth that permitted only one party to the cause to present any sworn evidence at all.

The jury, in contrast, promised a remarkably reliable source of systemic legitimacy. Its usually private and inarticulate decisionmaking protected it from the sort of embarrassing public failures that so regularly threatened the oath. Although two oaths all too easily could conflict, the jury's verdict stood alone and, at least within the system's formal bounds, was almost immune from contradiction. Moreover, whether by tradition or conscious design, the jury's verdict has been largely impenetrable. There never has been a mechanism by which the defendant or anyone outside the system could command the jury to reveal its decisionmaking processes. ${ }^{599}$ The jury's secrecy is an aid to legitimacy, for the privacy of the jury box shrouds the shortcomings of its methods.

One source of legitimacy the jury could never comfortably claim is divinity. Despite its other obvious advantages, the jury lacked what the oath could offer at a time when the recent abolition of the ordeal had left the system in search of a substitute source of divine sanction. Exactly when and precisely why the system began to feel comfortable enough with the notion of human factfinding to begin expanding the jury's lie-detecting role remain mysteries. The answers no doubt have something to do with the progressive secularization and democratization of English and American societies. Perhaps they also have something to do with the sheer passage of time and our ever greater familiarity with the jury, whose great old age helped win it reverence. In any event, one thing may be said with some certainty about the system's gradual abandonment of the oath and its embrace of the jury as its source of legitimacy in truthfinding: It was exceedingly slow. No matter how vividly we try to paint the jury's superiority as a source of legitimacy, the system gave up its hold on the security of the oath and invested the jury with the role of lie detector only with great reluctance. I have not tried here to explain the slow pace of change. Perhaps the resistance to change by common law institutions does not require much explanation.

But slow as it may have been, change was inexorable. Once the process of shifting lie-detecting authority to the jury had begun, it was likely to proceed until the jury had absorbed near-complete autonomy over the

599. Today the law goes to great lengths to protect the pnvacy of the deliberation process Sre Fbi) R. EviD. 606(b) (generally barring testimony of jurors to impeach a jury's verdict): Tanner $v$ United States, 483 U.S. 107, 122-25 (1987) (interpreting Rule 606(b) to prevent jurors from testifying that other jurors had used alcohol and narcotic drugs during the tnal). In 1956, after the Chicago Jury Project bugged the deliberations of several civil junes with the tnal judges" permission. Congress made it a cnne to record jury deliberations in a federal court. See Act of Aug. 2. 1956. ch. 879. $\$ 1.70$ Stal 935 (codıfied as amended at 18 U.S.C. $\$ 1508$ (1984 \& Supp. 1996)): of. JAY KATZ EXPERIMENTATION wmH HLMAN BEINGS 67, 84-91 (1972) (reproducing the transcript of a 1955 Senale subcommttee heanng at which University of Chicago Law School Professor Hamy Kalven. Jr, was accused of Communist leanings because of his role in the buggings). 
factfinding process. That was in part because the conditions required to sustain the oath as a source of legitimacy were fundamentally at odds with the jury's mode of operation. To protect the oath, the system had to exclude whole categories of testimony, but as Bentham and his followers made clear, for the jury to discern the truth it had to hear all the witnesses.

That the transition, once begun, proved unstoppable was due also to the power of those it served. One could cast the jury's increasing factfinding autonomy as a defeat for judges, who thereby lost power to control outcomes as the jury gained in power. The judges, however, perhaps saw it differently. For them, the power of decision was a political minefield, where false steps ended careers. Sir Thomas More saw that this was so in 1533. "I durst as well trust the truth of one judge as of two juries," he wrote. "But the judges be such wise men, that for the avoiding of obloquy they will not be put in the trust. ${ }^{1600}$ Hale remarked following the judgment in Bushel's Case, ${ }^{601}$ which forbade judges to punish juries for their verdict, that "it were the most unhappy case that could be to the judge, if he at his peril must take upon him the guilt or innocence of the prisoner." ${ }^{02}$ No doubt George Jeffreys, who presided with such relish over many of the late Stuart treason trials and over the perjury trial of Titus Oates and who took such evident pleasure in steering the juries toward guilty verdicts, had time to rethink the virtues of such judicial prerogatives as he whiled away his last days in the Tower of London. ${ }^{603}$

The inexorable flow of factfinding power to the jury was due, finally, to the jury's capacity to erase all blemishes. The system's need for legitimacy, as Edson Sunderland wrote in 1920, demands that " $[t]$ he record . . be absolutely flawless, but such a result is possible only by concealing, not by excluding mistakes." ${ }^{604}$ The jury's hidden decisionmaking process and its one- or two-word verdicts leave all mistakes and causes for criticism locked in the black box of the jury room. The jury's inscrutability, in Sunderland's marvelous imagery,

covers up all the shortcomings which frail human nature is unable to eliminate from the trial of a case.... [C]oncrete details are swallowed up, and the eye of the law, searching anxiously for the realization of logical perfection, is satisfied .... It serves as the great

600. GreEn, supra note 19, at 115 n.29 (quoting SIR ThOMAS MORE, THE APOLOGY OF SIR THOMAS MORE, KNIGHT 150 (1930) (1533)).

601. 124 Eng. Rep. 1006 (C.P. 1670); see supra note 596.

602. 2 HALE, supra note 98, at 312-13; see also 1 HOLDSWORTH $3 \mathrm{~d}$ ed., supra note 43 , at 348 (stating that the collaboration of the jury "helps to preserve the dignity of the Bench; for, if the judge preserves this judicial attitude, no odium can attach to him whatever be the verdict of the jury"); 1 STEPHEN, supra note 28 , at 573 (stating that trial by jury "saves judges from the responsibility-which to many men would appear intolerably heavy and painful - of deciding simply on their own opinion upon the guilt or innocence of the prisoner").

603. See 10 Dictionary OF NATIONAL BIOGRAPHY, stipra note 123, at 718; KENYON, stupra note 162 , at 259.

604. Edson R. Sunderland, Verdicts, General and Special, 29 YALE L.J. 253, 262 (1920). 
procedural opiate, which draws the curtain upon human errors and soothes us in the assurance that we have attained the unattainable. ${ }^{\text {ous }}$

Because it emits no light, the black box of the jury room has become the system's black hole, drawing into itself all of the questions of fact for which the system needs an unquestionable answer.

We could perhaps regard the wonderful convenience of jury lie detecting with more equanimity if there were any sound evidence that juries are good at this task. But most of the evidence we have suggests that juries have no particular talent for spotting lies. Not only do experimental subjects rarely perform much better than chance at distinguishing truth from falsehood, but they think they are better lie detectors than they are. ${ }^{607}$ And we could perhaps feel more complacent about where this long history has brought us if we knew that we had reached at last a stopping point where we could pause to assess the state of affairs. But the jury's lie-detecting role is still growing. In the last decade or two, more than half the states have relaxed their hearsay rules to admit evidence of out-of-court statements made by child victims of sexual abuse. ${ }^{608}$ The hearsay rule traditionally has rested on the presumption

605. Id. Sunderland was speaking of the institution of the general verdict and not of jun decisionmaking generally. But of course the vinue of the general serdict is that it does not (as do special interrogatories) require the jury to disclose its thought processes

606. See Mark Gregory Frank, Human Lie Detection Ability as a Function of the Liar's Motsiation I (1989) (unpublished Ph.D. disseration. Comell Unversily) (on file with author) Lie-detecung talent is not an easy thing to measure. In the context of real trals. ue almost never can knou if the jun has made correct credibility judgments. To measure the talent of juron as lie detectors, therefore, we hase to reson to the techniques of the social sciences. Almost all allempts by social scientists to measure lie-delectung talent have two shortcomings. The first. and less damning. is that these studies generally measure the capacity of persons but not of jurors to detect lies They mahe little altempt to see if the collectuve. deliberative process improves the accuracy of lie detection

The second, far greater flaw of these studies is that they fall to replicate with any realism the trial witness's intense interest in being believed. See id. Sometumes the allempls of sucial seienusts to create a real incentive to lie seem ridiculous. In one expenment. subjects were ashed to make stalements about whether they had cheated on an exam. The expenmenters asked half of them to prefend that they really had cheated on the exam and the other half to pretend that they had been unjustly accused The researchers then tested to see if experimental jurors could tell wto was "lyıng." Wellbom, supra note 586, at 1082

Another study employed nursing students as expenmental lars. Researchers told the students that their capacity to lie effectively was an imporant par of being a good nurse The rescarchen then asked the would-be nurses to watch a video screen and to describe what they siw on the video as pleasint ocean scenes. At some point, the image on the screen switched to one of homble camage. but the nurses were told to describe it as a flowery park. Later the researchers showed videotipes of the nursing students to experimental jurors to test whether they could tell when the students were telling the truth and when they were lying about the images on the screen. The study found that very few viewers of the videotapes "did better than chance" at this task. See PAUL EKMAN. TELLING LIES: CLL ES TO DECEIT I THE MARKETPLACE. POLITICS, AND MARRIAGE 54-56, $85-87$ (1992): see also Franh. supra, at 14-15 (reporting a study employing "liar's poker," in which successful lars recelved small monelan rewards)

607. See Wellbom, supra note 586, at 1082-88 (summanizung studies)

608. See LUCY S. MCGOLGH. CHILD WITNESSES- FRAGILE VOICES IN TIE AWERICA I LEAL SYSTEU 146, 169-88 (1994); Dana D. Anderson, Note. Assessing the Reliabilin of Chuld Tesimom in Se rual Abuse Cases, 69 S. CAL. L. REV. 2117, 2128-30 (1996) The debate surrounding these new chld hearsay laws has focused on the defendant's incapacity through cross-examınation to expose possible lies There has been no general expression of concem about the jury's capacity to discharge its new lie-detecting task We see here yet another example of social and political forces bnnging about a change in the lau that has the 
that it is beyond the jury's power to assess the credibility of an out-of-court speaker. ${ }^{609}$ Now, in cases of child sexual abuse, jurors confront a credibility question that is an order of magnitude more difficult than anything they have seen before: Jurors have to decide whether they believe a child whom they cannot see, ${ }^{610}$ whose sense of reality they cannot assess, and who apparently lacks the emotional maturity to testify in court-and they have to decide whether their belief in the child's credibility is solid enough to support a verdict beyond a reasonable doubt. ${ }^{611}$

It is a fair prediction that in the coming decades, the hearsay rule will break down more generally, and we will commit to the jury's black box a whole new category of credibility determinations. We can put such questions before the jury entirely without fear of embarrassment, because the way the jury resolves the questions and, in all likelihood, the soundness of its answers will remain forever hidden. Perhaps the allure of the black box as a means toward apparent certainty in an uncertain world has tempted us to entrust the jury with more and harder questions than it has the power to answer. Today, after an evolution spanning centuries, there is almost no kind of credibility dispute we will not trust a jury to resolve. The system no longer shields juries, as it did for centuries, from head-to-head conflicts of oaths. Hence we can ask the jury whether it believes the sworn accuser or the sworn defendant. We can do so even when their two stories are equally plausible, even when there is no other evidence in the case. And even if the jury returns a verdict of guilty, indicating it has resolved this intractable dilemma beyond a reasonable doubt, we accept its verdict without hesitation. For the jury is the system's lie detector.

unintended consequence of expanding the jury's lie-detecting role.

609. I have chosen not to include the development of the rule against hearsay in my sketch of the historical development of the jury's lie-detecting role. That is in part because the credibility of out-of-court witnesses is a somewhat tangential inquiry. It is in part, too, because the development of the rule against hearsay is a complicated affair, one that has absorbed a great deal of the labor of others and is better left for a later, separate study. Even the timing of the rule's first emergence in common law courts is a topic of debate, with Wigmore and an older school fixing the event in the late 17th or early 18th century, and Langbein putting it almost a century later. Compare 5 WIGMORE, supra note 44 , $\$ 1364$, at 9, with Langbein, supra note 286, at 1174-76, 1186-90. Frank Hermann has recently argued that the hearsay rule has a far deeper heritage than its application in common law courts. See Frank R. Herrmann, The Establishment of a Rule Against Hearsay in Roman-Canonical Procedure, 36 VA. J. INT'L L. 1 passim (1995).

610. Some state statutes provide for videotaped statements by absent child witnesses, which permit a jury to see and hear the witness-though the quality of recording of course varies. See MCGouGH, sıpro note 608 , at $194-95,213-14,220$.

611. One study found mock jurors to be quite willing to believe an absent child witness. See Jonathan M. Golding et al., The Believability of Hearsay Testimony in a Child Sexual Assault Trial, 21 LAW \& HUM. BEHAV. 299, 306-09, 312, 316, 318-19 (1997). 
Appendix A: Statutes and Constitutional Provisions Permitting TESTIMONY BY CIVIL PARTIES

Alabama:

Arkansas:

California:

Connecticut:

Delaware:

Florida:

Georgia:

Illinois:

Indiana:

Kansas:

Kentucky:

Louisiana:

Maine:

Maryland:
An Act in Relation to the Competency of Witnesses. No $403 . \$ 1,1867$ Ala. Acts 435,435 .

ARK. CONST. of 1874, sched., $\$ 2$, reprinted $i n$ A DIGEST OF TIE STATUTES OF ARKansas 106-07 (Columbla. Press of E.W Siephens 1894)

An Act To Amend an Act Entuled an Act To Regulate Proceedings in Civil Cases in Courts of Justuce of this State, ch. CCCCXXVIII. $\$ 2.1863$ Cal Stal 701.701

An Act for the Regulation of Civil Actions (adopted 18-48) (codified at CoNN REv. STAT. tit. I. ch. X. § 141 (1849))

An Act in Reference to the Competency of Witnesses, ch 537. $\$ 1.16$ Del Laws 708,708 (1881).

An Act Conceming Tesumony. ch 1472. \$1.1865 Fla. Acts 35. 35 (adopted Jan $16,1866)$

An Act To Declare Ceraun Persons Compeient Witnesses as in the Act Set Out. and for Other Purposes, No 189. pmbl \& \$1, 1866 Ga. Laws 138. 138

An Act Relating to the Competency of Witnesses in Civil Cases, $\$ 1,1867$ III Laws $183,183$.

An Act in Relation to Winesses and To Repeal Section 238 of Article 13 of the Act, ch. XXVII, $\$ 2,1861$ lnd Acts 51, 52.

An Act To Establish a Code of Cival Procedure, ch. XI. t1t X. $\$ 310,1858$ Kan Sess. Laws 65,115 .

An Act To Amend the Laws of Evidence in this Commonwealth. ch. 139. \$ 1 , 1872 Ky. Acts 12, 12.

An Act To Amend and Re-Enacl Artucle Tweniy-Two Hunured and Sixiy-One of the Civil Code of the Statc of Loussiana. No. 70. $\$ 1,1867$ La Acts 1+1. 1+1-12

An Act Additional in Relation to Witnesses, ch. 266, $\$ 1,1856$ Me Laws 314. 314.

Act of Mar. 2, 1864, ch. 109, \$11, 1864 Md Liws 136, 136 
Massachusetts: $\quad$ An Act To Enable Parties in Civil Actions and Proceedings To Be Witnesses Therein, ch. 305, 1857 Mass. Acts 655, 655.

Michigan: Act of Mar. 11, 1861, No. 125, §§ 4339-4340, 1861 Mich. Pub. Acts 168, 168.

Mississippi: An Act To Establish Circuit Courts, To Define Their Jurisdictions, and To Regulate the Practice Therein (adopted 1857) (codified at MISS. REv. CODE ch. LXI, \& 17, arts. 190-93).

Missouri: An Act in Relation to the General Statutes of the State of Missouri, ch. 144, $\$ 1$, 1866 Mo. Laws 586, 586.

New Hampshire: An Act Relating to the Competency of Witnesses, ch. 1952, §1, 1857 N.H. Laws $1868,1868$.

New Jersey: $\quad$ A Supplement to the Act Entitled "An Act Concerning Witnesses," ch. CLXVI. $\S 1,1859$ N.J. Laws $489,489$.

New York: An Act To Amend Section Three Hundred and Ninety-Nine of the Code of Procedure, ch. 353, 1857 N.Y. Laws 744, 744.

North Carolina: $\quad$ An Act To Improve the Law of Evidence, ch. 43, pmbl. \& $\$ 1-2,1866$ N.C. Laws $112,112$.

Ohio: $\quad$ An Act To Establish a Code of Civil Procedure, tit. X, ch. $1, \S 310,1853$ Ohio Laws 57, 108.

Oregon: $\quad$ An Act To Provide a Code of Civil Procedure, ch. 1, tit. III, § 700, 1862 Or. Laws 3, 174-75.

Pennsylvania: $\quad$ An Act Allowing Parties in Interest To Be Witnesses, No. 31, § 1, 1869 Pa. Laws 30,30 .

Rhode Island: $\quad$ Certain Provisions Respecting Evidence, tit. XXVII, ch. 187, $§ 34-35,1857$ R.I. Acts $30,30$.

South Carolina: $\quad$ An Act To Make Parties, Plaintiffs and Defendants, in All Cases, Competent to Give Testimony in Such Cases, in Like Manner as Other Witnesses, No. 4780 , 1866 S.C. Acts $377,377-78$.

Tennessee: An Act To Make the Rules of Evidence in the Federal and State Courts, Uniform, ch. LXXV, \& 1, 1868 Tenn. Pub. Acts 94, 94. 
Texas: An Act Further Regulatung Proceedings in the Several Couns of the State of Texas, ch. CIV, $\S 1,1871$ Tex. Gen. Laws 108, 108.

Vermont: An Act Relating to Witnesses. No. 13. $\$ 1.1852$ Vi Laws 11.11

Virginia: An Act To Repeal an Act Entutled an Act Relatung to Wuncsses, th 21. \$1. 1866 Va. Acts 87,87 .

West Virginia: An Act in Relation to the Competency of Witnesses. ch $14 . \$ \$ 1-2.186 \mathrm{~S} W \mathrm{Va}$ Acts 10, 10. 
APPENDIX B: STATUTES AND CONSTITUTIONAL PROVISIONS ABOLISHING RULES AGAINST TESTIMONY BY NONWHITES

Alabama:

Arkansas:

California:

Florida:

Georgia:

Illinois:

Indiana:

Kansas:

Kentucky:

Louisiana:

Maryland:

Mississippi:

Missouri:
An Act To Protect Freedmen in Their Rights of Person and Property in This Statc, No. 86, § 1, 1866 Ala. Acts 98, 98 (adopted Dec. 9, 1865).

An Act To Declare the Rights of Persons of African Descent, No. 35, § 1, 1867 Ark. Acts 98, 99.

An Act To Amend an Act Entitled an Act To Regulate Proceedings in Civil Cases in the Courts of Justice in this State, ch. LXVIII, $\S 1,1863$ Cal. Stat. 60, 60.

FLA. CONST. of 1865, art. XVI, § 2, reprinted in 1866 Fla. Acts 125, 145.

Act of Dec. 15, 1865, tit. XXXI, No. 251, § 1, 1866 Ga. Acts 239, 239.

Act of Feb. 7, 1865, § 1, 1865 Ill. Laws 105, 105.

An Act Defining Who Shall Be Competent Witnesses in Any Court or Judicial Proceedings in This State, ch. LVI, $\S 1,1866$ Ind. Acts 162, 162 (adopted Dec. $20,1865)$.

An Act To Establish a Code of Civil Procedure, ch. XI, tit. X, $\S 314,1858$ Kan. Laws 65, 116.

An Act To Amend the Laws of Evidence of this Commonwealth, ch. 139, $\$ 7$, $1872 \mathrm{Ky}$. Acts 12, 14.

An Act To Amend and Re-Enact Article Twenty-Two Hundred and Sixty-One of the Civil Code of the State of Louisiana, No. 70, 1 1, 1867 La. Acts 141, 143.

Although the other states on this list (with the possible exception of Delaware) repealed their racial exclusion laws by statute or constitutional provision, in Maryland the change seems to have been the result of a statc court ruling construing the Federal Civil Rights Act. ${ }^{612}$

An Act To Confer Civil Rights on Freedmen, and for Other Purposes, ch. IV, $\$$ 4, 1866 Miss. Laws 82, 83.

MO. CONST. of 1865, art. I, § 3, reprinted in MO. GEN. STAT. 20, 21 (1866). 
North Carolina:

Ohio:

Oregon:

South Carolina:

Tennessee:

Virginia:

West Virginia:
An Act Concerning Negroes and Persons of Color or of Mixed Blook. ch $\$ 0 . \S$ 9, 1866 N.C. Pub. Laws 99, 102.

An Act To Authorize the Establishment of Separate Schools for the Education of Colored Children, and for Other Purposes, $\S 6,1849$ Ohso Luws 17, 18

An Act To Provide a Code of Civil Procedurc. ch. 1. ut. III. $\$ 701.1862$ Or Acts 3, 174-75.

An Act To Declare the Rights of Persons Lately Known as Slaves and as Free Persons of Color. No. 4798. § I. 1866 S.C. Acts 393.393

An Act To Do Justice and Render Persons of Afracan and Indaan Descent Competent Witnesses in the Courts of this State, ch. XVIII, 1866 Tenn Acts 24, 24.

TEX. CONST. of 1866, ar. VIII, § 2, reprinted in 1866 TEX GEN LAWS 881

An Act in Relation to the Testumony of Colored Persons. ch 24. $\$ 1.1866 \mathrm{Va}$ Acts $89,89$.

An Act To Amend the Law in Relation to the Competency of Witnesses, ch. 89. $\S 1,1866 \mathrm{~W}$. Va. Acts 85.85 . 
. 